Uo!s!n!a

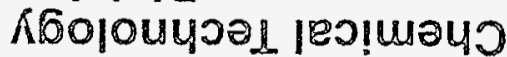

Uo!s!n!

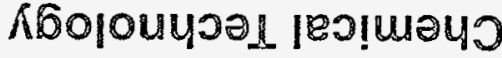
Uo!s!n!a

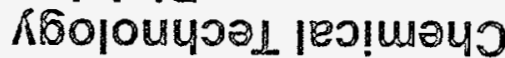
Uo!s!n!O

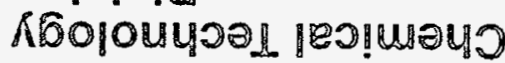

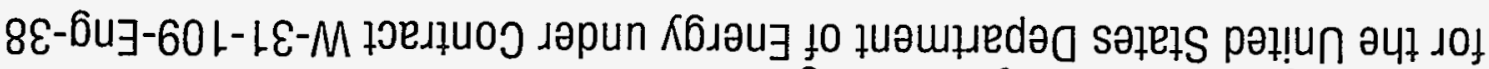

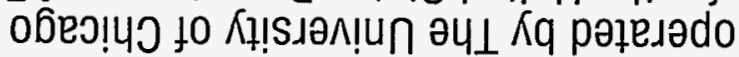

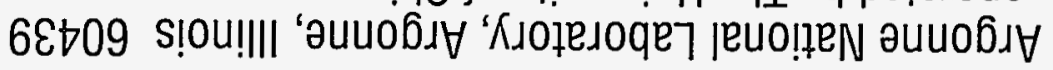

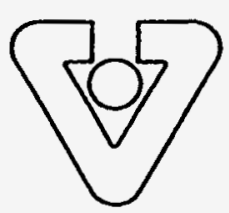

(a)

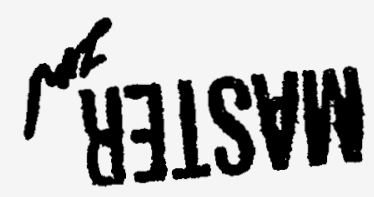

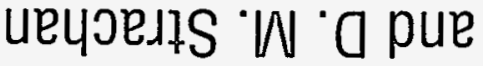

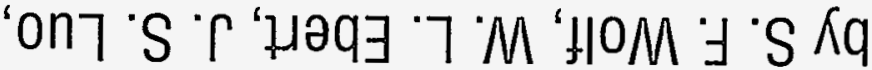

slonpodd OlseM

Кำ

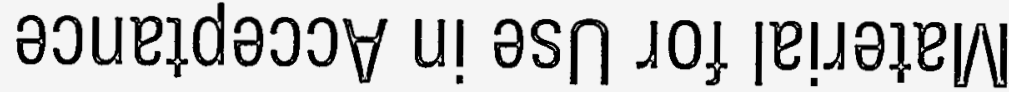

psepuets e pue aseg eteg $\forall$
UO!sing

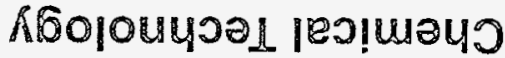
u!s!N!O

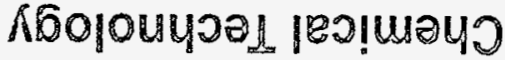
Ua!s!n!a

К601044201 1eग!U240 UO!S!A!

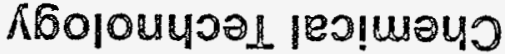
Uo!s!n!a

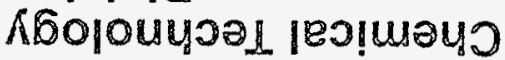
ทо!ฺ!n!O

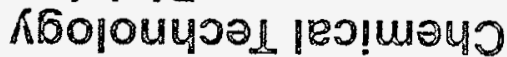
U०!ร!ณ!

A6olouบsal jeo!usys Uо!S!ก!ด

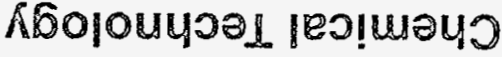
Uo!s!n!a

k6ojouysal leo!usus U०!s!n!

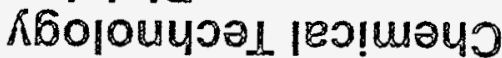
Uo!s!n!

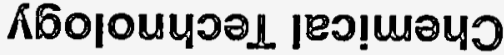
Uo!s!n!

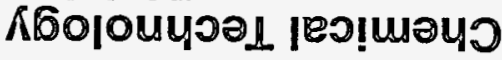
Uo!s!^!@

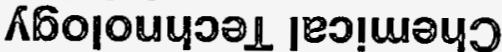
Uo!s!n!

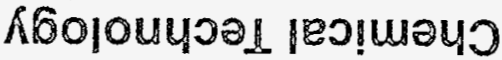
U०!s!n!

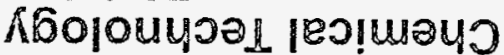
Uo!s!n!a

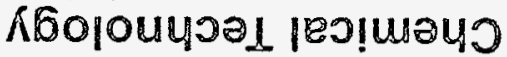
uo!s!n!

K6ojouyor les!uayo 
Argonne National Laboratory, with facilities in the states of Illinois and Idaho, is owned by the United States government, and operated by The University of Chicago under the provisions of a contract with the Department of Energy.

\section{DISCLAIMER}

This report was prepared as an account of work sponsored by an agency of the United States Government. Neither the United States Government nor any agency thereof, nor any of their employees, makes any warranty, express or implied, or assumes any legal liability or responsibility for the accuracy, completeness, or usefulness of any information, apparatus, product, or process disclosed, or represents that its use would not infringe privately owned rights. Reference herein to any specific commercial product, process, or service by trade name, trademark, manufacturer, or otherwise, does not necessarily constitute or imply its endorsement, recommendation, or favoring by the United States Government or any agency thereof. The views and opinions of authors expressed herein do not necessarily state or reflect those of the United States Government or any agency thereof.

Reproduced from the best available copy.

Available to DOE and DOE contractors from the Office of Scientific and Technical Information

P.O. Box 62

Oak Ridge, TN 37831

Prices available from (423) 576-8401

Available to the public from the National Technical Information Service

U.S. Department of Commerce 5285 Port Royal Road Springfield, VA 22161 


\section{DISCLAIMER}

Portions of this document may be illegible electronic image products. Images are produced from the best available original document. 
Distribution Category:

Radioactive Waste

Tank Remediation (UC-2030)

ANL-98/9

\section{ARGONNE NATIONAL LABORATORY \\ 9700 South Cass Avenue}

Argonne, Illinois 60439-4837

\section{A DATA BASE AND A STANDARD MATERIAL FOR USE IN ACCEPTANCE TESTING OF LOW-ACTIVITY WASTE PRODUCTS}

by

S. F. Wolf, W. L. Ebert, J. S. Luo, and D. M. Strachan

Chemical Technology Division

April 1998 
TABLE OF CONTENTS

Page

ABSTRACT

EXECUTIVE SUMMARY

I. INTRODUCTION AND BACKGROUND.

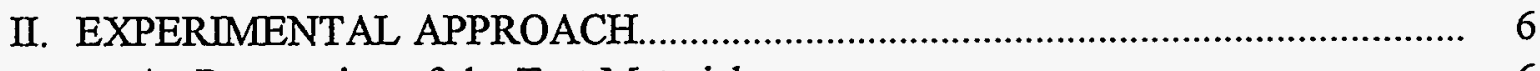

A. Preparation of the Test Material................................................................ 6

B. Development of a Data Base for Evaluating Test Results .............................. 8

C. Other Tests............................................................................................. 11

1. ANS/ANSI 16.1 Tests .............................................................. 12

2. Toxicity Characteristic Leaching Procedure ....................................... 12

3. Vapor Hydration Tests ................................................................ 12

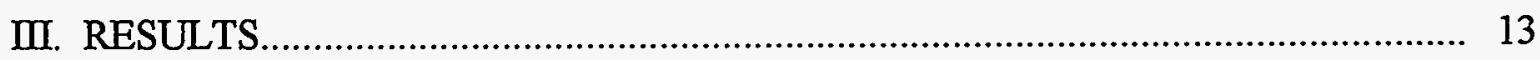

A. Preparation and Analysis of LRM-1 Glass ................................................ 13

1. Glass Bulk Composition ..................................................................... 13

2. Glass Microstructure ..................................................................... 13

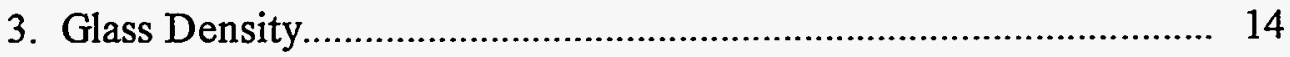

4. Glass Compressive Strength ……................................................ 15

B. Test Methods .................................................................................... 15

1. Product Acceptance Tests .............................................................. 15

a. Results of Water Analyses................................................... 15

b. Results of Test Blank Analyses............................................... 16

c. Results of Leachate Analyses.................................................. 16

2. Results of ANS 16.1 Tests ......................................................... 17

3. Results of Toxicity Leaching Procedure............................................ 17

4. Results of Vapor Hydration Tests................................................. 17

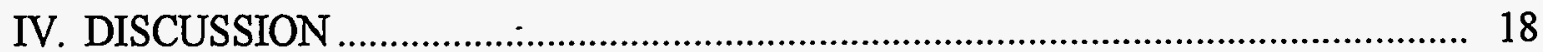

A. Effects of Varying Test Parameters ........................................................ 18

1. Causes of Systematic Differences in Mean PAT Response................ 19

a. Analysis of Variance: All Factors......................................... 19

b. Analysis of Variance: Glass/Water Mass Ratio ...................... 19

c. Analysis of Variance: Temperature ......................................... 20

d. Analysis of Variance: Test Durations ..................................... 20

e. Analysis of Variance: Test Initiation/Termination Dates........ 20

f. Analysis of Variance: Solution Reanalyses............................. 21

2. Intrinsic Test Variance .................................................................. 22 


\section{TABLE OF CONTENTS (contd.)}

B. Calculation of Glass Dissolution Rate................................................... 23

C. Comparison of Tests at Different Temperatures......................................... 25

D. Use of LRM-1 as a Standard Test Material.............................................. 26

E. Evaluation of the Adequacy of the Specified Test Method ............................ 27

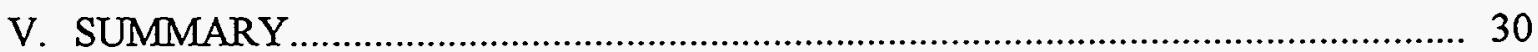

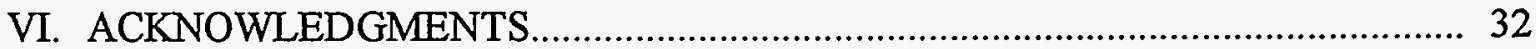

VII. REFERENCES

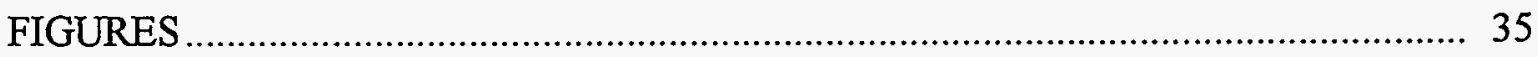

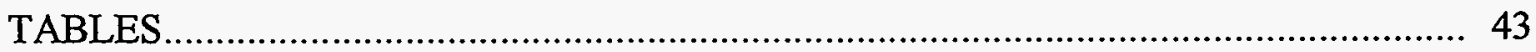

APPENDIX A. Analyses of LRM-1 ................................................................... 71

APPENDIX B. Test Initiation and Termination Data for PATS and Blanks ................. 72

APPENDIX C. Results of Analyses of Minor Elements ............................................. 77

APPENDIX D. Analysis of Variance by Glass/Water Mass Ratio ................................ 93

APPENDIX E. Analysis of Variance by Temperature.................................................111

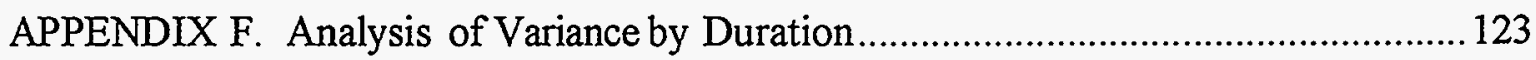

APPENDIX G. Analysis of Variance by Triplicate Test.............................................. 141

APPENDIX H. Analysis of Variance by Replicate Analysis ........................................ 177

APPENDIX I. Analysis of Variance of Normalized Elemental Concentrations by Glass/Water Mass Ratio, Temperature, and Duration...................... 185 


\title{
A DATA BASE AND A STANDARD MATERIAL FOR USE IN ACCEPTANCE TESTING OF LOW-ACTIVITY WASTE PRODUCTS
}

\author{
S. F. Wolf, W. L. Ebert, J. S. Luo, and D. M. Strachan
}

\begin{abstract}
We have conducted replicate dissolution tests following the product consistency test (PCT) procedure to measure the mean and standard deviation of the solution concentrations of $\mathrm{B}, \mathrm{Na}$, and $\mathrm{Si}$ at various combinations of temperature, duration, and glass/water mass ratio. Tests were conducted with a glass formulated to be compositionally similar to low-activity waste products anticipated for Hanford to evaluate the adequacy of test methods that have been designated in privatization contracts for use in product acceptance. The data base provided by these tests can also be used to assess the credibility of the results of tests with waste products that are reported by contractors. Statistical analyses of the test results indicate that, whereas the mean concentrations increase with increasing temperature, mass ratio, and duration, the standard deviation of replicate tests is not significantly affected by these test parameters over the range of values that was evaluated. The test precision was determined primarily by the analytical uncertainty in the solution analyses, which will vary with the technique used to quantify the solution concentrations. An important finding from this set of tests is that the solution concentrations generated in tests at $20^{\circ} \mathrm{C}$ will likely be too low to measure the dissolution rates of waste products reliably. Based on these results, we recommend that the acceptance test be conducted at $40^{\circ} \mathrm{C}$. Tests at $40^{\circ} \mathrm{C}$ generated higher solution concentrations, were more easily conducted, and the measured rates were easily related to those at $20^{\circ} \mathrm{C}$. Replicate measurements of other glass properties were made to evaluate the possible use of LRM-1 as a standard material. These include its composition, homogeneity, density, compressive strength, the $\mathrm{Na}$ leachability index with the ANSI/ANS 16.1 leach test, and if the glass is characteristically hazardous with the toxicity characteristic leach procedure. The values of these properties were within the acceptable limits identified for Hanford low-activity waste products. The reproducibility of replicate tests and analyses indicates that the glass would be a suitable standard material.
\end{abstract}




\section{EXECUTTVE SUMMARY}

We conducted laboratory tests following the product consistency test (PCT) procedure to measure the effects of key parameters on the mean and standard deviation of the response of a glass that was formulated to be representative of expected immobilized Hanford low-activity waste (ILAW) products, namely, the LRM-1 glass. As specified in the Hanford Tank Waste Remediation System Phase 1 Privatization Contracts (TWRS-PCs), the radionuclide release from ILAW products must be calculated based on the dissolution rate measured in a 7-day PCT conducted at $20^{\circ} \mathrm{C}$. Tests were conducted with LRM-1 glass to measure the precision and accuracy with which solution concentrations can be quantified under those and similar test conditions. A key purpose of these tests was to evaluate the adequacy of the specified test method for measuring the dissolution rate of a glass that is representative of expected waste products. The data base from these tests results can also be used to evaluate the credibility and validity of durability test results reported by the Private Contractors as part of the acceptance procedure for $I L A W$ products. Such a data base is needed, in part, because the values of several PCT parameters are not specified in the contracts. The data base provides insight into the effects of key test parameters on the PCT results.

The LRM-1 glass was formulated and made at Argonne National Laboratory-East (ANLE) specifically for use in these tests and as a possible standard material. The glass was formulated to be representative of likely $\mathrm{LAW}$ products for Hanford. The composition of LRM-1 glass was not designed to match particular vendor formulations, which have not yet been released at the time of this writing. Instead, the glass was formulated based on other glasses that were developed to immobilize Hanford low-activity waste. The glass was subjected to replicate tests in a matrix designed to determine the effects of temperature $\left(20,40\right.$, and $\left.70^{\circ} \mathrm{C}\right)$, glass/water mass ratio (1:10 and 1:1), and test duration ( 3 and 7 days) on the amount of glass that dissolved, which was monitored by the solution concentrations of $\mathrm{B}, \mathrm{Na}$, and $\mathrm{Si}$. All tests were conducted with demineralized water and in Type $304 \mathrm{~L}$ stainless steel vessels. Solution concentrations were measured with inductively coupled plasma-mass spectrometry (ICP-MS).

Statistical analysis of the test results indicates that, while the mean concentrations of B, $\mathrm{Na}$, and $\mathrm{Si}$ all increase with increased temperature, duration, and mass ratio values, none of these test parameters had a significant effect on the standard deviations of the results of replicate tests. The within-day variability of replicate tests was insignificant compared to the between-day variability of replicate tests. Test results indicate the methodology used to analyze the solutions had a greater effect on the reproducibility of the glass response than did the values of the test parameters or test execution. The technique used to analyze the test solutions must provide high sensitivity for the simultaneous multi-elemental analysis of small volumes of complex, dilute

solutions. The analytical uncertainty for other techniques will likely be similar to or higher than that of ICP-MS, which we used for these tests.

An important finding of these tests is that it is likely that solution concentrations from tests conducted under the conditions specified in the TWRS-PCs (7-days and $20^{\circ} \mathrm{C}$, at a 
presumed glass/water mass ratio of 1:10) will be too near the analytical detection limit to provide a sufficiently accurate or precise measure of the dissolution rates of Hanford ILAW products. Both the instrumental limitations and background levels, which are dependent on the laboratory environmental conditions, will affect the ability to quantify the glass dissolution rate. The extreme care that we took in conducting these tests with regard to laboratory and equipment cleanliness, consistency of test procedure, and the calibration of analytical equipment should not be expected for routine testing at contracting laboratories. The data base for LRM-1 glass indicates that tests conducted at $40^{\circ} \mathrm{C}$ for 7 days at a mass ratio of $1: 10$ provide solutions that can be analyzed more reliably than those from tests at $20^{\circ} \mathrm{C}$. The rates measured at $40^{\circ} \mathrm{C}$ can also be extrapolated to $20^{\circ} \mathrm{C}$ with confidence.

The LRM-1 glass was subjected to several other tests and analyses that are required to be conducted with the Hanford $I \mathrm{LWW}$ products. These were conducted to evaluate the possible use of LRM-1 glass as an analytical standard material. The composition of the glass was measured by dissolving separate aliquots of the glass by different methods and then analyzing those solutions with ICP-MS, inductively coupled plasma-atomic emission spectroscopy (ICP-AES), and ion chromatography (IC). Comparison of the composition determined by the pooled results of those analyses with the as-batched composition preparation of LRM-1 glass resulted in the loss of about $90 \%$ of the added $\mathrm{Hg}$ and as much as $20 \%$ of the added alkali metals. Other glass components were retained at near the added levels. Examination of the microstructure of the glass verified that the glass was not phase separated (i.e., no glass/glass phase separation was detected) and that no phases had precipitated in the glass. The density of the glass was measured by buoyancy to be $2516 \pm 9 \mathrm{~kg} / \mathrm{m}^{3}$. Although the TWRS-PCs do not specify a density requirement per se, the density of the waste product must be less than about $3800 \mathrm{~kg} / \mathrm{m}^{3}$ to satisfy the volume and mass requirements specified for the waste package. The compressive strength was measured to be $226 \pm 57 \mathrm{MPa}$; the TWRS-PCs require the compressive strength of the waste form to be greater than $3.45 \mathrm{MPa}$. Triplicate ANSI/ANS 16.1 leach tests were also conducted with the glass, and the average $\mathrm{Na}$ leachability index was measured to be $15.4 \pm 0.1$; the TWRS-PCs require the Na leachability of the waste form to be greater than 6.0. The glass, which contains $\mathrm{Ba}, \mathrm{Cd}, \mathrm{Cr}, \mathrm{Hg}$, and $\mathrm{Pb}$, was subjected to and passed TCLP for all five elements in triplicate tests. The performance of the LRM-1 glass in these tests satisfies the product requirements specified in the TWRS-PCs, and the measured reproducibility indicates that it could serve as an analytical standard material for use in these tests. 


\section{INTRODUCTION AND BACKGROUND}

In this report, we describe work conducted at Argonne National Laboratory-East (ANLE) toward developing a product acceptance test for immobilized low-activity waste (ILAW) forms. This work was performed under the auspices of the U.S. Department of Energy (DOE) Tanks Focus Area (TFA) for immobilization. The objective of this task is to provide a data base that can be used to evaluate test results reported by private contractors as a part of the acceptance procedure for ILAW forms and a certified standard material from which a documented response can be obtained under a range of test conditions and from which can be used to verify the results of tests and analyses conducted with actual waste forms. The guidance for this work is given in the Program Execution Guidance (PEG) Technical Task Plan (TTP) No. CH27WT31. All experimental work conducted in this task was performed in compliance with the Quality Assurance (QA) requirements promulgated in the document DOE/RW-0333P, rev. 6 "Quality Assurance Requirements and Description, Office of Civilian Radioactive Waste Management," and DOE Order $5700.6 \mathrm{C}$ for waste form scientific investigations performed in the Chemical Technology Division (CMT) of ANL-E.

Several sites in the DOE complex may privatize the immobilization function for tank waste remediation. The waste forms that are produced will be required to meet contractual product specifications to ensure their suitability for transfer, handling, and disposal. Inspection, testing, and documentation will be utilized in the acceptance process, and to authorize payment to the Private Contractor. Standard test methods that allow quantitative determination of product acceptability will be used. For example, the TWRS-PCs for the separation and immobilization of Hanford tank wastes states that the durability of waste forms must be acceptable, as measured by the dissolution rate in a seven-day Product Consistency Test (PCT) conducted either at $20^{\circ} \mathrm{C}$ or up to $90^{\circ} \mathrm{C}$, provided the results of tests at higher temperatures can be shown to be related to results at $20^{\circ} \mathrm{C}$ [DOE-1996]. The tests discussed in this report provide a data base that can be used to verify that waste products comply with this requirement.

The rationale for selecting a PCT at $20^{\circ} \mathrm{C}$ to measure the dissolution rate included the goal of providing an upper bound to the long-term (e.g., 10,000 years) dissolution rate with the results of a short-term (e.g., seven days) laboratory test. Dissolution tests with borosilicate glasses over the past two decades have indicated that the long-term dissolution rate is controlled by surface hydrolysis reactions [e.g., STRACHAN-1994; CUNNANE-1994]. The most important reaction is the hydrolysis of Si-O-Si bonds, the rate of which decreases as orthosilicic acid builds up in solution. It was reasoned that the dissolution rate measured under the relatively high solution concentrations that are generated in a seven-day PCT provides a conservative upper bound to the dissolution rates that may occur over long times.

The PCT was developed for use by DOE high-level radioactive waste vitrification facilities to monitor the consistency of waste forms. Two variations of the test procedure have been standardized by the American Society for Testing and Materials (ASTM): PCT Method A and PCT Method B [ASTM-1994]. The PCT Method A was developed specifically to evaluate 
whether the durability and elemental release characteristic of high-level waste glasses are consistently controlled during production. It is conducted at $90^{\circ} \mathrm{C}$ in ASTM type I water (i.e., demineralized water) in a Type $304 \mathrm{~L}$ stainless steel vessel for seven days. The test is conducted with crushed glass of the $-100+200$ mesh size fraction and at a glass/water mass ratio of 1:10. The PCT Method B does not specify values for key test parameters of temperature, leachant solution composition, selection of the test vessel, glass/water mass ratio, or test duration. Although the test that is specified in the TWRS-PCs to measure the glass dissolution rate and the release rate of radionuclides is a variation of the generic PCT Method B, not all of the test parameters needed to conduct a PCT Method B test are specified in the TWRS-PCs. While the temperature and duration are specified, the size fraction of the glass, leachant composition, glass/water mass ratio, and vessel restrictions are not specified.

Very few PCTs have been conducted with waste glasses at the low temperatures (e.g., $20^{\circ} \mathrm{C}$ and lower) relevant to envisioned $\mathrm{LAW}$ disposal facilities. Most tests have been conducted at higher temperatures relevant to high-level waste facilities (e.g., $90^{\circ} \mathrm{C}$ ). Therefore, we have conducted tests to provide a data base that can be used to evaluate the results of tests conducted with values of test parameters that may be used by the contractors to measure the extent of glass dissolution for product acceptance or to relate tests at elevated temperatures to $20^{\circ} \mathrm{C}$. To distinguish the tests conducted to support $\Pi \mathrm{LAW}$ product acceptance from the general PCT Method B test, we will refer to the former tests as the product acceptance tests (PATs) in this report. While the data base developed by these tests is meant to provide a means to evaluate test results reported during Phase 1 Hanford Privatization Contracts, it can also be used to identify the set of test parameters that results in the highest precision and can be specified in subsequent contracts. The availability of such a specific test method will eliminate the variations in methodology that are possible in the Phase 1 contracts.

A nonradioactive standard glass was formulated and made at ANL to measure the variance in the response of the glass under various test conditions. This glass was used to (1) generate a data base that can be used to evaluate the effects of test parameters in the PAT and (2) to measure the intralaboratory precision of the test execution and analyses. The same glass will subsequently be used in a round robin test program to measure the interlaboratory precision of the PAT based on the response of the glass. Glass of the same composition as used in these tests may be procured for use as a standard material. The glass was formulated to be compositionally representative of waste products anticipated for Hanford low-activity waste streams in terms of the major glass-forming components. The formulation of the glass has been described previously [EBERT-1998]. It was desired that the glass composition be similar to anticipated $\mathrm{LAW}$ so that the dissolution mechanism of the reference glass and actual $\mathrm{LAW}$ were likely to be similar in the PAT. Some elements that are regulated by the Resource Conservation and Recovery Act (RCRA) were included in the glass, but radioactive components were not included. A radioactive analytical standard may be developed in the future to verify that the radionuclide concentration limits given in the TWRS-PCs are met. 


\section{EXPERIMIENTAL APPROACH}

To develop the PAT, we first formulated a reference glass for use in these tests and for possible use as a standard material. The composition of the glass was formulated to be relevant to the LAW products that may be produced during remediation of Hanford tank wastes; it also included glass-making components which may be used in LAW products for other sites. The targeted composition of this glass is given in Table 1. The technical basis for selecting this glass composition has been summarized in the report EBERT-1998. We designated this candidate standard test material as Low-Activity Reference Material-1 (LRM-1). The suitability of LRM1 glass for use as a standard test material will be evaluated both by the response of the glass to various durability tests and the physical properties of the glass. We have evaluated several physical characteristics of LRM-1 glass including the macroscopic homogeneity as determined from replicate bulk chemical analysis, microscopic homogeneity as determined with microstructural analyses, bulk density as determined by buoyancy, and compressive strength.

We then conducted a series of tests to quantify the response of the glass under various test conditions. Replicate tests with LRM-1 were conducted to measure the mean performance and variance of the response of the glass at different test durations (three and seven days), temperatures $\left(20,40\right.$, and $\left.70^{\circ} \mathrm{C}\right)$, and glass/water mass ratios $(1: 1$ and $1: 10)$. In addition, we evaluated the response of LRM- 1 glass to other test methods, including the American National Standards Institute/American Nuclear Society test procedure 16.1 (ANSI/ANS-16.1), the Toxicity Characteristic Leaching Procedure (TCLP), and the vapor hydration test (VHT). The tests and analyses that were conducted with LRM-1 glass is summarized in below.

Tests and Analyses Performed

- 108 PATs, 36 blanks

- 3 ANS/ANSI 16.1 leachability tests, 1 blank

- 3 TCLP tests, 1 blank

- 3 ANL VHTs

- 4 chemical dissolutions and multiple analyses

- 8 measurements of glass density by buoyancy

- 4 measurements of compressive strength

- characterization of glass microstructure

\section{A. Preparation of the Test Material}

A large quantity of glass was needed to perform all the required tests and measurements while maintaining a level of homogeneity consistent with the requirements of a standard material. 
Test samples were needed: monoliths with specific dimensions and crushed glass of specific size fractions, enough to perform all of the tests and analyses listed above.

The precursor frit was prepared by mechanically mixing sufficient amounts of dried reagent-grade chemicals (oxides, carbonates, chlorides, fluorides, iodates, and sulfates) to produce $2500 \mathrm{~g}$ after vitrification. The specific chemicals and the amounts used to prepare the precursor frit are listed in Table 2. Dried chemicals were weighed individually, mixed by grinding in a mortar and pestle under acetone, and dried overnight at $90^{\circ} \mathrm{C}$ in a drying oven. Initial scoping melts had been performed to determine appropriate preparation procedures and melting conditions [EBERT-1998]. Twelve batches of precursor frit were prepared by the following procedure. Approximately $200 \mathrm{~g}$ of the chemical mixture was transferred into a $\mathrm{Pt} / \mathrm{Rh}$ crucible. The crucible was placed into a furnace set at $800^{\circ} \mathrm{C}$. The temperature of the furnace was step increased to $900^{\circ} \mathrm{C}$ after one hour, then to $1000^{\circ} \mathrm{C}$ after another hour. The chemicals were vitrified in this manner to facilitate the outgassing that occurred during the initial stages of glass preparation. After an hour at $1000^{\circ} \mathrm{C}$, the furnace was step increased to $1250^{\circ} \mathrm{C}$. The melt was held at approximately $1250^{\circ} \mathrm{C}$ for a total of about two hours. During this time, the crucible was briefly removed from the furnace every $0.5 \mathrm{~h}$ so that the melt could be swirled to facilitate thorough mixing. After two hours at $1250^{\circ} \mathrm{C}$ with the intermittent swirling, the melt was removed from the furnace and quenched by partial emersion in water. This process fractured the glass so that it could be removed from the crucible relatively easily. Approximately $1 \mathrm{~g}$ of the melted precursor frit was archived and the rest was set aside for further processing. This procedure was repeated 12 times to vitrify the entire stock chemical mixture. The material was crushed with a platen mortar and pestle, ground in a tungsten carbide mill, and mixed overnight in a high-density polyethylene (HDPE) container on an automated jar mill. This homogenized crushed glass was used to make the LRM-1 glass we tested and analyzed. It was batch coded GS636 for ANL QA purposes.

To make the LRM-1 glass used for crushed glass samples, each of six 250-g batches of the precursor frit was melted at $1250^{\circ} \mathrm{C}$ for $0.5 \mathrm{~h}$ in a $\mathrm{Pt} / \mathrm{Rh}$ crucible, quenched by partial immersion of the crucible in water, and broken out of the crucible. The glass from the six batches was mixed together and used for the PATs, TCLP tests, and for compositional and microstructural examinations.

Another 200-g aliquot of precursor frit was melted at $1250^{\circ} \mathrm{C}$ in an alumina crucible and annealed at about $500^{\circ} \mathrm{C}$ overnight to make the glass used for monolithic samples. An alumina crucible was used so that sufficiently long cores could be cut from the glass boule for use in the ANSI/ANS 16.1 leach tests. Glass near the crucible interface was not used for testing or analysis, in case the glass melt had reacted with the crucible. Glass from the center of the boule was cored and sliced into monoliths for use in ANSI/ANS 16.1 tests, VHTs, and density and compressive strength measurements. The remaining precursor frit was archived for future use.

Samples of LRM- 1 were prepared for testing by crushing then sieving to isolate the -100 +200 mesh fraction (i.e., the fraction passing through a $150 \mu \mathrm{m}$ sieve but retained by a $75 \mu \mathrm{m}$ 
sieve, U.S. Standard designation) for PATs and to $<9.5 \mathrm{~mm}$ particles for use in the TCLPs. The $100+200$ mesh fraction was cleaned with water and methanol following the cleaning steps detailed in the PCT procedure [ASTM-1994]. The washed glass was examined by scanning electron microscopy (SEM) to verify that fines had been removed and to document the size and shape of the glass particles.

Bulk elemental analyses were performed on aliquots of the clean $-100+200$ mesh size fraction to determine the actual composition of LRM-1. Three aliquots of the glass were dissolved in a mixture of ultra-high purity hydrofluoric, nitric, and hydrochloric acids, and the resulting solutions were analyzed. Two of these dissolutions were performed in a closed Parr vessel to minimize loss of volatile species that might form during the dissolution (solutions CVD1 and CVD2). One dissolution was taken to dryness in an open Teflon beaker and fumed with perchloric acid to convert insoluble fluorides to soluble species (solution OVD1). Aliquots of these solutions were used for multiple determination of all glass constituents with ICP-AES and ICP-MS. In addition, one aliquot of the clean $-100+200$ mesh size fraction was fused with potassium hydroxide and dissolved (solution FX1) for analysis of the anion content by IC. Microstructural analysis were performed with samples of both the annealed glass and the cleaned $-100+200$ mesh fraction crushed glass by scanning electron microscopy-energy dispersive spectroscopy (SEM-EDS) and transmission electron microscopy-energy dispersive spectroscopy (TEM-EDS). The density of eight monolithic samples were measured by buoyancy [ASTM-1993]. The compressive strength of four monolithic samples of the glass were also determined [ASTM-1993a].

\section{B. Development of a Data Base for Evaluating Test Results}

Development of data base for the PAT focused primarily on measuring the effects that test duration, temperature, and glass/water mass ratio have on the mean and standard deviation of the test results. We systematically and independently varied those parameters to allow statistical analysis of the variance of test results. The test matrix was also designed to evaluate the effects of day-to-day variability of test initiation and termination and the day-to-day variability of solution analysis. Multiple tests on the glass with demineralized water were conducted at temperatures of 20,40 , and $70^{\circ} \mathrm{C}$, at glass/water mass ratios of $1: 10$ and $1: 1$ (tests conducted with $1 \mathrm{~g}$ of glass per $10 \mathrm{~g}$ of water and $5 \mathrm{~g}$ of glass per $5 \mathrm{~g}$ of water, respectively), and for test durations of three and seven days. The PCT Method A used for high-level waste forms requires water that meets the requirements of ASTM Type I water [ASTM-1991]. The water used in these tests was purified with laboratory ion-exchange and filter modules and analyzed to verify that it met ASTM Type I requirements of electrical conductivity and composition.

Tests were conducted in 22-mL Type 304L stainless steel vessels. All vessels were cleaned following the PCT procedure for cleaning new vessels [ASTM-1994]. Each vessel was stamped with a unique number for the purpose of identification. The vessels are sealed with a Teflon gasket and compression fitting. A constant-temperature water bath was used for tests conducted at $20^{\circ} \mathrm{C}$ and convection ovens were used for tests conducted at 40 and $70^{\circ} \mathrm{C}$. The 
temperatures of the ovens and the water bath were set with NIST-traceable thermometers and continuously monitored with thermocouples. The temperatures of the ovens were recorded by a data logger every 12 hours. The oven temperatures remained within $\pm 1^{\circ} \mathrm{C}$ of the set temperature throughout the testing program.

The test matrix that was designed to measure the effects of the various test and experimental factors is summarized in Table 3. Each test was assigned a unique test number. Aliquots of the solution and glass taken for analysis were identified using the test number. The first letter in the designation $(\mathrm{P})$ indicates that the test is part of the replicate PAT matrix. The second letter ( $A$ through $\mathrm{L}$ ) refers to the combination of test parameters used in that test (i.e., duration, temperature, and glass/water mass ratio). The third letter indicates whether the sample contains glass (T) or is a test blank (B). The final number (n) refers to the replicate number for each combination of test parameters.

A total of nine replicate tests with glass and three blank tests were conducted for each combination of temperature, glass/water mass ratio, and test duration. The nine tests with glass were run as three sets of triplicate tests that were initiated on three separate days in order to allow the random day-to-day variability introduced by initiating, terminating, and analyzing solutions to be evaluated. An experimental blank test was run simultaneously with each set of triplicate tests at each combination of temperature and test duration. Solutions generated from each test with the designation P-B-T, P-C-T, P-H-T, and P-I-T were analyzed twice in separate analysis procedures to determine the variability associated with solution analysis. The term "analysis procedure" is used in this report to identify sets of solution that were analyzed together, on the same day, and with the same instrument calibration.

Tests were initiated by adding crushed glass and demineralized water to clean vessels. The amount of glass that was added to the vessel was measured to $\pm 0.01 \mathrm{~g}$; enough water was added so that the glass/water mass ratio was exactly 1 or 10 , to the nearest $0.01 \mathrm{~g}$. The measured solution concentrations can be compared directly only because the glass/water mass ratios are exactly the same. Because of uncertainty in the accuracy of the specific surface area of the crushed glass, normalization of test results to the same mass ratio - or glass surface area/solution volume $(\mathrm{S} / \mathrm{V})$ ratio - would introduce additional uncertainty to the results of the tests.

A sample of the demineralized water used as the leachant for each set of tests was retained for analysis. During test assembly, the glass was gently agitated by slowly rotating the vessel to ensure that no air bubbles were trapped and that all the glass was wetted. The vessel lid and Teflon gasket were then placed on the vessel and the compression nut tightened to about 120 $\mathrm{ft}-\mathrm{lbs}$. After all the test vessels in a set were assembled, they were placed in 40 and $70^{\circ} \mathrm{C}$ ovens or the $20^{\circ} \mathrm{C}$ water bath. Before placement in the water bath, the vessels were first placed in a plastic zip-lock bag. Most of the air was forced from the bag and it was sealed. The vessels were set in the water bath so that they were completely submerged, with the sealed bag tops above the water level. This placement to prevented water from becoming trapped in the closure fitting and obscuring the mass change of the assembled vessel. Vessels were placed directly in the 
ovens. The time at which the vessels were placed in the ovens or the water bath was recorded as the time of test initiation.

The time at which the vessels were removed from the ovens or water bath was recorded as the time of test termination. At the completion of each set of tests, each vessel was weighed to check for mass loss and then opened. A $0.5-\mathrm{mL}$ aliquot of the leachate solution was immediately removed and sealed in a small vial for $\mathrm{pH}$ analysis. The remaining leachate solution was removed from the test vessel and passed through a $0.45-\mu \mathrm{m}$ pore filter into a clean sample bottle. The filtrate was stabilized with ultra-high purity nitric acid. The was $\mathrm{pH}$ measured with a standard laboratory combination $\mathrm{pH}$ electrode and meter calibrated with commercially available $\mathrm{pH}$ buffer standards that bracketed the $\mathrm{pH}$ of the test solutions. All $\mathrm{pH}$ measurements were conducted at room temperature. These measurements were completed within an hour after the tests were terminated to minimize the effects of $\mathrm{CO}_{2}$ absorption into the solution.

The filtered leachate solutions were analyzed by ICP-MS. Prior to analysis, the solutions were diluted with $2 \%$ nitric acid so that the solute concentrations were within the optimum concentration range for the instrument. The dilution factors used for tests conducted with each set of parameters were determined by analyses of small aliquots of solution from the first set of triplicate tests. Solutions were spiked with elemental internal standards to compensate for any instrumental drift that may occur during analysis. The resulting solution contained $50 \mathrm{ng} / \mathrm{mL}$ each of $\mathrm{Be}, \mathrm{Sc}, \mathrm{In}$, and $\mathrm{Bi}$. The instrumental blank was determined prior to calibration of the ICPMS by replicate analysis of a $2 \%$ nitric acid solution that was spiked with internal standards. The instrumental blank was used as the zero concentration for the calibration curve and is subtracted from all standards and samples in the analysis procedure. Instead of reporting a detection limit for the ICP-MS analytical results, we report the more conservative limit of quantitation (LOQ). The LOQ is calculated as 10 times the standard deviation of the instrumental blank [CURRIE-1968]. It estimates the lowest concentration for which the measured concentration is quantifiable at the $95 \%$ confidence level when the instrumental blank is well known. The LOQ may vary slightly from day to day due to small differences in the performance of the instrument.

Quantitative analysis of all solutions was performed by direct calibration of the instrument with NIST-traceable multi-elemental standards followed by linear regression to calculate a linear calibration curve. Tests solutions were analyzed for all elements in LRM-1 glass that are amenable to routine determination with ICP-MS; $\mathrm{Al}, \mathrm{B}, \mathrm{Ba}, \mathrm{Cd}, \mathrm{Cr}, \mathrm{Fe}, \mathrm{K}, \mathrm{La}, \mathrm{Li}$, $\mathrm{Mg}, \mathrm{Mn}, \mathrm{Mo}, \mathrm{Na}, \mathrm{Ni}, \mathrm{Pb}, \mathrm{Si}, \mathrm{Sn}, \mathrm{Ti}$, and $\mathrm{Zr}$. Separate calibrations and LOQs were determined for every set of analyses. Quality control (QC) solutions were analyzed prior to analysis of the first unknown sample and after the tenth unknown sample during every set of analyses. These solutions contain known concentrations of all components that were determined in the leachate solutions and are used to verify that the instrument remains within calibration during the analyses. We estimate the accuracy of all analyses to have a probable error $<15 \%$, as determined by analysis of QC solutions. 
Results of solution analyses from the PAT matrix were examined with one-way analysis of variance (ANOVA) to determine if the fixed-effect factors temperature, glass/water mass ratio, test duration, and day-to-day variability had a significant effect on mean $\mathrm{Si}, \mathrm{Na}$, and $\mathrm{B}$ concentrations. Analysis of variance allows us to test whether a fixed-effect factor (a potential source of systematic variation or bias) is significant compared to random sources of variation or random error [NETER-1988]. One-way ANOVA allows us to test, for example, whether the variability of the PAT response caused by different test temperatures, glass/water mass ratios, test durations, or day of initiation/termination is significant when compared to the variability due to random effects. As always in a significance test, we tested the null hypothesis that all of our results are random samples from a single population. We attempted to disprove the null hypothesis statement with ANOVA. Each time we applied ANOVA to our data, we calculated a $\mathrm{P}$-value. We used the P-value as an estimate of the probability that the variability in PAT response to any fixed-effect factor was due to chance. A P-value less than 0.05 indicated that there is only one chance in twenty that the observed variability was due to chance alone. In other words, the null hypothesis is disproved and the fixed-effect factor has a significant effect on the mean PAT response if the P-value is less than 0.05 .

An ANOVA was performed initially on the whole data base to compare all of the fixed effect-factors (i.e., different test temperature, glass/water mass ratio, test duration, and day of initiation/termination) simultaneously. Analysis of variance was then repeatedly performed on portions of the data to test the null hypothesis for each fixed-effect factor individually. For example, we tested the effect that test duration has on the mean response for tests conducted at $20^{\circ} \mathrm{C}$ and a mass ratio of $1: 10$ by analyzing the results of tests P-A-T-n and P-G-T-n. We also tested whether analyzing identical samples on different days affects the overall variability of the mean response of the PAT.

After extensive ANOVA tests to help us identify all possible causes of systematic variation, we normalized our compositional data to decouple their effect on the data set. We then tested the null hypothesis of differences in standard deviations of tests performed with different test parameters with the F-statistic. We used this test to determine if any one set of test parameters constituted a test with the lowest intrinsic variability.

\section{Other Tests}

The response of LRM-1 glass was measured in the ANSI/ANS 16.1 leach test [ANSI/ANS-1986], which is a requirement of the TWRS-PCs, and the Toxicity Characteristic Leaching Procedure [FR-1990], which is required for wastes containing RCRA-regulated components. The response of the glass was also measured in VHTs. The VHT is used to accelerate waste glass corrosion to provide insight into a material's long-term behavior. In particular, the test is used to produce alteration phases that form as the glass corrodes and to measure the impact of their formation on continued glass corrosion rate. While the VHT does not address a specific requirement in the TWRS-PCs, it is relevant to whether or not the dissolution rate calculated in the PAT is likely to bound the long-term dissolution rate. Vapor hydration 
tests are being used to study the long-term corrosion behavior of vitrified waste forms in support of the Hanford Low-Level Waste Performance Assessment project. The dissolution rates of some glasses, including glasses formulated for LAW, have been observed to increase significantly after some phases form [BAKEL-1995]. VHTs are currently being conducted at ANL as screening tests for Contractor glasses in the assessment of the Hanford Phase 1a acceptance procedure. Tests were conducted with LRM-1 to relate the long-term corrosion mechanism of LRM-1 with that of other glasses that have been studied and to determine if similar alteration phases form and affect the glass corrosion rate. The test matrix for these tests is in Table 4 .

\section{ANS/ANSI 16.1 Tests}

The TWRS-PCs require measurement of the leachability index of sodium with the ANSI/ANS 16.1 test. This test procedure was developed to quantify the leaching characteristics of solidified waste forms. Results are cast in terms of a mathematical parameter called a "leachability index," which is a measure of the diffusion controlled release of components from the waste form. Although the dissolution of waste glasses is a surface reaction, the release of $\mathrm{Na}$ through ion exchange may be diffusion-controlled very early in the corrosion process.

Triplicate tests were conducted with LRM-1 glass in Teflon vessels with deionized water following the ANSI/ANS 16.1 procedure to measure the leachability index of the glass based on sodium. The ANSUANS 16.1 procedure requires cylindrical samples to have length/diameter ratios between 0.2 and 5 . The three samples of LRM-1 glass that were prepared as cylinders all measured $3.45 \mathrm{~mm}$ in length and $9.80 \mathrm{~mm}$ in diameter giving a length/diameter ratio of 0.35 . The ratio of the leachant volume to the geometric surface area is required to be $10 \pm 0.2 \mathrm{~cm}$. The sample surface area, which is $2.57 \mathrm{~cm}^{2}$, required the use of $25.7 \pm 0.5 \mathrm{~mL}$ of water to attain the required volume/surface area ratio.

\section{Toxicity Characteristic Leaching Procedure}

Triplicate TCLP tests were conducted on LRM-1 glass. These tests were conducted according to the Environmental Protection Agency Toxicity Characteristic Leaching Procedure Method 1311 [FR-1990]. One experimental blank test with the extraction fluid was conducted at the same time as the with the tests with glass. Tests solutions were analyzed for major glass components and RCRA-listed metals.

\section{Vapor Hydration Tests}

Tests were conducted by suspending two monolithic samples from a stainless steel rod with Teflon thread in a Type 304L stainless steel vessel to which $0.15 \mathrm{~mL}$ of deionized water was added. The vessel was sealed with an annealed copper gasket and compression fitting and placed in a convection oven set at a temperature $150^{\circ} \mathrm{C}$ for the scheduled test duration. Tests were run for seven, 28 , and 56 days. At the end of the test, the sample was examined with SEM/EDS to characterize surface alteration and the formation of new phases. 


\section{RESULTS}

\section{A. Preparation and Analysis of LRM-1 Glass}

Initial scoping melts of batched chemicals showed that the melting point of LRM-1 is in the range of $1150-1200^{\circ} \mathrm{C}$. The chemical mixture fused at $800^{\circ} \mathrm{C}$ and decarbonated without substantial foaming. The melt evolved a white gas continuously throughout the entire melting procedure. We observed a yellow solid that had condensed on the crucible wall when the crucible was removed from the furnace for observation. We performed one scoping test to examine the melt at $1350^{\circ} \mathrm{C}$. We observed that the amount of gas evolved from the melt decreased with time at this temperature. While processing the glass at a lower temperature would reduce the loss of volatile elements, observations of a trial melt performed at $1150^{\circ} \mathrm{C}$ indicated that undissolved chemical reagents remained at the bottom of the crucible. The glass was made at $1250^{\circ} \mathrm{C}$ to maximize the mixing of the melt and minimize the loss of volatile elements so that the final product would be a homogeneous glass with a composition close to the target.

\section{Glass Bulk Composition}

Results of analyses of LRM-1 and the techniques used to determine concentrations of each component are given in Table 5. The mean concentrations and standard deviations presented were calculated from as many as fifteen individual analyses of the four dissolved samples. Results for individual analyses are given in Appendix A. The total mean sum of calculated oxides is $95.8 \mathrm{wt} \%$. Although a measured oxide total $<100 \%$ could be indicative of loss of some major component such as $\mathrm{Si}$ or B during dissolution, these low-biased results were reproduced for two separate closed vessel dissolutions and from analyses with two independent analysis techniques. Thus, the low oxide total value is probably not due to incomplete recovery during dissolution and or during analyses. It may be that the chemical form and the gravimetric constants used to calculate the glass composition is not accurate due to the presence $\mathrm{Cl}, \mathrm{F}, \mathrm{I}, \mathrm{P}$, and $\mathrm{S}$ in the glass. It is also possible that some carbon remains in the glass as a result of incomplete decomposition of the carbonates used to batch the glass. Further work with an emphasis on accurately determining the composition of LRM-1 would be required to provide a definitive explanation. The TWRS-PCs require that the concentrations of all waste form, matrix, and filler components present at greater than 0.5 percent by weight be reported.

Results of analyses indicate the systematic loss of approximately $15-20 \%$ of each alkali element during preparation of the LRM-1 glass. The mercury content of the glass was $90 \%$ lower than the as-batched concentration, indicating that it too was volatilized during glass preparation. All other components matched the as-batched composition reasonably well.

\section{Glass Microstructure}

Visually, LRM-1 is a dark green translucent glass. Examination of a sample of the annealed glass with an optical microscope and by SEM revealed that the consistency of the glass 
was uniform, and that a few bubbles were trapped within the glass. The chemical composition was measured with SEM-EDS at nine random spots across the surface of the sample. No compositional heterogeneities were found on the scale that can be resolved by this technique, which has a spatial resolution of about $2 \mu \mathrm{m}$. The composition measured with SEM-EDS was consistent with the composition of the glass as determined with ICP-AES, ICP-MS, and IC. Results of these replicate analyses indicate that LRM-1 is compositionally homogeneous at the macroscopic level.

Figure 1 is an SEM photomicrograph of several particles of clean $-100+200$ mesh fraction of LRM-1 dispersed on carbon tape. The dimensions of the glass particles typically ranged from 50 to $200 \mu \mathrm{m}$, which is consistent with the mesh fraction. The particles were free of fines and the fracture surfaces showed no indication that inclusions or secondary phases were present in the glass. Several particles of clean $-100+200$ mesh fraction of LRM- 1 were fixed in epoxy resin and polished cross sections prepared for SEM-EDS examination and semi-quantitative analysis to verify that the quenched LRM-1 glass was also homogeneous on the microscopic scale. Analyses of the chemical compositions with SEM-EDS of several randomly selected glass particles revealed no evidence of compositional heterogeneities on a $\sim 2-\mu \mathrm{m}$ scale. Figure 2 is a TEM photomicrograph of a typical area in a thin-sectioned sample of LRM-1 prepared with ultramicrotomy. Analysis of the chemical compositions with TEM-EDS of several randomly selected glass particles revealed no evidence of compositional heterogeneities on a $\sim 10-\mathrm{nm}$ scale. Based on the results of SEM-EDS and TEM-EDS analysis, we conclude that LRM-1 is compositionally homogeneous at the microscopic level.

\section{Glass Density}

The density of the LRM-1 glass was measured by buoyancy following a standardized procedure [ASTM-1993]. In this procedure, the mass of a monolithic glass sample is measured in air and in deionized water at room temperature. The density of the glass is calculated from the difference in the measured masses. The results of density measurements for nine samples of the glass are given in Table 6; the replicate samples are designated LRM-1 D1 through LRM-1 D8. The measured density of LRM-1 is $2516 \pm 9 \mathrm{~kg} / \mathrm{m}^{3}$, with a percent relative standard deviation (\% rsd) of $0.4 \%$. Although the TWRS-PCs do not specify an acceptable range of product densities, the total mass and volume limits specified for waste packages will limit the acceptable density. The maximum mass of each package cannot exceed $10,000 \mathrm{~kg}$, and the container must have an external dimension of $1.8 \mathrm{~m}$ (length) $\times 1.2 \mathrm{~m}$ (width) $\times 1.2 \mathrm{~m}$ (height), $\pm 0.2 \mathrm{~m}$. The volume based on the mean dimensions is $2.59 \mathrm{~m}^{3}$. Excluding the mass of the container and any void space, the density of the glass cannot exceed $3800 \mathrm{~kg} / \mathrm{m}^{3}$.

We assessed the bias in our measurements by performing density measurements on two glass mass density standard reference materials (SRMs) obtained from NIST, namely the sodalime glass mass density standard SRM-1826a and the lead silica glass mass density standard SRM-1827a. The certified mass densities of these two SRMs are $2.548932 \pm 0.000023 \mathrm{~g} / \mathrm{cm}^{3}$ and $3.593014 \pm 0.000025 \mathrm{~g} / \mathrm{cm}^{3}$, respectively. The densities of the standard glasses were measured 
before and after measurements of LRM-1. Analyses of the two standard glasses SRM-1826a and SRM-1827a give mean densities and standard deviations of $2.549 \pm 0.001 \mathrm{~g} / \mathrm{cm}^{3}$ and $3.592 \pm 0.004$ $\mathrm{g} / \mathrm{cm}^{3}$, respectively. The calculated errors of our measurements relative to the SRMs are $+0.003 \%$ for SRM- $1826 \mathrm{a}$ and $-0.03 \%$ for SRM-1827a. The uncertainty in our density measurements, therefore, appears to be dominated by the precision of our measurements on LRM-1 and not bias in the methodology.

\section{Glass Compressive Strength}

The compressive strength of LRM-1 glass was measured following ASTM procedure C 39 [ASTM-1993a]. Four cylindrical samples that had a length/diameter ratio of 2.05, which is within the requirements of the ASTM procedure C 39 , were prepared for analysis. The top and bottom faces of the samples were cut parallel. The raw data and results of compressive strength measurements on LRM-1 are given in Table 7. The maximum load reached was used for the determination of compressive strength. The compressive strength was determined by dividing the peak load by the cross-sectional area of the specimen. The mean compressive strength was $32,828 \pm 9525 \mathrm{psi}$, or $226 \pm 65 \mathrm{MPa}$, well exceeding the $3.45 \mathrm{MPa}$ lower limit that is specified in the TWRS-PCs. The fracture mode could not be identified because all samples were completely shattered during the measurement.

\section{B. Test Methods}

\section{Product Acceptance Tests}

After the scheduled test duration, test vessels were removed from the water bath or the convection ovens and weighed to determine mass loss. The masses of all terminated tests were within $0.02 \mathrm{~g}$ of the initial mass, which we assume to be the uncertainty for measurement of the mass change. Each vessels was opened and an $0.5-\mathrm{mL}$ aliquot was removed for $\mathrm{pH}$ measurement. The remaining solution was passed through a $0.45-\mu \mathrm{m}$ pore polycarbonate filter and acidified with concentrated ultra-pure nitric acid. The reacted glass was retained. The raw data for test terminations are given in Appendix B.

\section{a. Results of Water Analyses}

Aliquots of the demineralized water used as the leachant solution in the PATs (and also in other tests) were analyzed with ICP-MS. Results of analyses for $\mathrm{Na}, \mathrm{Si}, \mathrm{B}, \mathrm{Al}$, and $\mathrm{K}$ are given in Table 8. Results of analyses for all other elements that were quantified are given in Appendix $\mathrm{C}$. The only quantifiable component was $\mathrm{Na}$, which had a concentration of $20.1 \pm 8.1$ $\mu \mathrm{g} / \mathrm{L}$. The concentration of $\mathrm{Si}$ was consistently $<60 \mu \mathrm{g} / \mathrm{L}$, which is well below the $1000 \mu \mathrm{gL}$ limit for ASTM Type I water [ASTM-1991]. Concentrations of B, Al, and $\mathrm{K}$ were less than the LOQ for the analysis ( $\angle \mathrm{LOQ}$ " in Table 8 ). The electrical resistivity of all of the water collected from the purifier was $>17.9 \mathrm{M} \Omega \cdot \mathrm{cm}$ at $25^{\circ} \mathrm{C}$, meeting the requirement of $>16.67 \mathrm{M} \Omega \cdot \mathrm{cm}$ for ASTM Type I water. 


\section{b. Results of Test Blank Analyses}

One experimental test blank was included with each set of triplicate tests. The results of analyses of the solutions from these test blanks for $\mathrm{Na}, \mathrm{Si}, \mathrm{B}, \mathrm{Al}$, and $\mathrm{K}$ are given in Table 9. Results of analyses for all other elements determined are in Appendix C. Neither Si, B, nor $\mathrm{K}$ was quantifiable in any of the test blank solutions. Of the 36 blank tests performed sodium was quantifiable in 24 and aluminum was quantifiable in 11. We observed no correlation between the concentrations of the quantifiable elements with respect to leachate volume, test duration, or test temperature. This suggests that the background concentrations of $\mathrm{Na}$ and $\mathrm{Al}$ are limited by environmental laboratory factors. Table 9 gives the means and sample standard deviations and the relative standard deviations (\%rsd) for the measured $\mathrm{pH}$ and $\mathrm{Na}$ and $\mathrm{Al}$ concentrations for all blank tests. The PCT Method A procedure requires that the concentrations of monitored elements in test blanks be $<10 \%$ of the concentration of that element in the test solution [ASTM-1994]. The mean concentration of sodium in the test blanks was $84.7 \pm 27.3 \mu \mathrm{g} / \mathrm{L}$. According to the PCT-A standard, test leachates would be required to contain at least $847 \mu \mathrm{g} / \mathrm{L} \mathrm{Na}$. The mean concentration of aluminum of $9.86 \pm 6.48 \mu \mathrm{g} / \mathrm{L}$ requires that that test solutions contain at least $99 \mu \mathrm{g} / \mathrm{L}$ for the data to be considered valid. Silicon, B, and $\mathrm{K}$ concentrations were below the LOQ for the analysis procedure on the day they were analyzed. Therefore, we evaluate the minimum acceptable concentrations of those elements generated in PATs based on the LOQ values measured for those elements in the leachate solutions of tests with glass when they are analyzed.

\section{c. Results of Leachate Analyses}

Solution results including the measured $\mathrm{pH}$ and concentrations of $\mathrm{Na}, \mathrm{Si}, \mathrm{B}, \mathrm{Al}$, and $\mathrm{K}$ for all tests in the PAT matrix are given in Table 10a-d. Results of analyses for all other elements determined are in Appendix $\mathrm{C}$. The analysis of $\mathrm{Na}$ and $\mathrm{Si}$ in most tests required dilution of the leachate solutions. This is because ICP-MS cannot be used to reliably determine the concentrations of elements at concentrations $>10 \mathrm{mg} / \mathrm{L}$ without prior dilution. Solutions were prepared for analysis of some leachates with the following dilution factors (df): 1.005 for samples designated P-A-T and P-G-T; 10.000 for samples designated P-B-T, P-C-T, P-D-T, PE-T, P-H-T, P-I-T, P-J-T, P-K-T; and 100.000 for samples designated P-F-T and P-L-T. All of the other elements were quantified by directly analyzing the leachate solutions with only the addition of the internal standard. Elemental concentrations in experimental blank tests and demineralized water samples were determined with a dilution factor of 1.005 . Each set of triplicate tests were analyzed at the same time with the same instrument calibration. Experimental blanks from each of the three sets of tests were analyzed simultaneously, but with a different instrument calibration than was used for the test solution. All concentrations listed have been corrected for any dilution made during test termination and analysis. Concentrations less than the LOQ for a given analysis procedure are listed as upper limits. 
The means and sample standard deviations of the measured concentrations of $\mathrm{Si}$, $\mathrm{Na}, \mathrm{Al}, \mathrm{B}$, and $\mathrm{K}$ from the nine replicate PATs run under each set of conditions are summarized in Table 11 to facilitate comparison.

\section{Results of ANS 16.1 Tests}

The results from triplicate ANSI/ANS 16.1 tests are summarized in Table 12. The values given in Table 12 correspond to the calculations provided in the test procedure to determine the leachability index. Our analyses give a mean effective diffusivity of $1.67 \times 10^{-15} \mathrm{~cm}^{2} / \mathrm{s}$ and a mean $\mathrm{Na}$ leachability index of $15.3 \pm 0.1$ for the triplicate tests at all test intervals at the $99.9 \%$ confidence level. This result satisfies the requirement in the TWRS-PCs that the Na leachability index be greater than 6.0 .

\section{Results of Toxicity Leaching Procedure}

The TCLP was performed in triplicate on LRM-1. One experimental blank was performed at the same time. Scoping tests revealed that TCLP was to be performed with TCLP Fluid \#1. This solution was prepared by combining $5.7 \mathrm{~mL}$ glacial acetic acid, $500 \mathrm{~mL}$ of ASTM Type I water, $64.3 \mathrm{~mL} 1 \underline{\mathrm{N}}$ sodium hydroxide solution, and sufficient ASTM Type I water to make $1 \mathrm{~L}$. The $\mathrm{pH}$ of the resulting solution was 4.90 . Results of triplicate TCLP on LRM-1 are given in Table 13. The concentrations of RCRA-regulated metals in the leachates were less than the listed regulatory level; $\mathrm{LRM}-1$ contains $\mathrm{Ba}, \mathrm{Cd}, \mathrm{Cr}, \mathrm{Hg}$, and $\mathrm{Pb}$. The concentrations of $\mathrm{Ag}$, As and Se were measured for completeness. Concentrations of major glass constituents $\mathrm{Si}, \mathrm{B}$, and $\mathrm{Al}$ were also determined in the TCLP leachates, and the results of these analyses are included in Table 13. These were quantified to measure the reactivity of LRM-1 under these test conditions.

\section{Results of Vapor Hydration Tests}

Vapor hydration tests were performed for durations of seven, 28, and 56 days. Tests were terminated by removing the vessel from the oven and placing it in a 1-inch deep water bath, to condense the water vapor inside. After the vessel had cooled, the outside of the vessel was dried and the vessel was weighed to verify that water had not leaked out during the test. The vessel was then opened and the support rod and samples were removed. The $\mathrm{pH}$ of the condensed water was measured with $\mathrm{pH}$ paper to verify that water had not dripped from the sample during the test. The measured values were near neutral, which indicated that water did not drip from the samples. It is important that water not drip from the sample because the purpose of the test is to corrode the glass in highly concentrated solutions.

The monolithic glass samples were allowed to air dry and then were cut from the Teflon thread. They were inspected visually, with an optical microscope, and then with an SEM. Samples from all of the seven-, 28-, and 56-day tests had several "water marks": residual evaporite crystals. An SEM photomicrograph of sodium-rich evaporite crystals is shown in 
Figure 3. The mechanism by which the glass corrodes and these phases form in the VHTs is as follows. Water vapor sorbs onto the hygroscopic glass surface at silanol sites and alkali metals and eventually forms a thin film. About 0.5 -mL of water collects on each sample. This estimate is based on the amount added to the vessel and the amount needed to saturate the vapor phase in the vessel. Ion exchange causes alkali and alkaline earth metals to leach from the glass, generating an alkaline brine solution in the thin surface film. The glass corrodes in that brine, which is why the $\mathrm{pH}$ of water that recondensed in the bottom of the vessel can be used to indicate if solution drips from the sample. Eventually, enough glass will dissolve so that the surface film becomes saturated with respect to mineral phases. The test duration that is required for alteration phases to form depends on the dissolution rate of the glass and the phases itself. However, if the test is terminated before mineral phases form, then evaporation of the solution from the sample will leave crystallized salts on the sample. We observed these salts on the samples from the 7-, 28-, and 56-day tests. The crystallized salts generally contained $\mathrm{Na}, \mathrm{Ca}$, and $\mathrm{F}$. In addition, a secondary mineral phase was observed upon examination of the longest VHT, the 56-day test. It contained very small Si-Al-Na-K-bearing phases that had compositions consistent with zeolites (e.g., analcime) that are commonly formed during corrosion of alkali borosilicate glasses.

\section{DISCUSSION}

The results of tests conducted in this program are used (1) to identify those values of test parameters that result in the least variability in the response of a standard material, (2) evaluate the possible use of LRM-1 glass as a test standard material, and (3) to determine if the properties of the LRM-1 glass meet the criteria listed in the TWRS-PCs. We discuss first the series of replicate tests that were conducted to measure the mean response and reproducibility of the response of a glass under different test conditions. These results provide a data base for the selection of parameter values that could be used for a product acceptance test. The dissolution rates of LRM-1 glass under different conditions are then calculated from the mean responses. While the dissolution rates of LRM-1 glass do not address a specific need in the TWRS-PCs, the relationship between the rates calculated for tests at different temperatures are discussed to illustrate how the response at $20^{\circ} \mathrm{C}$ in a seven-day test can be approximated by tests at higher

temperatures. Factors that should be considered in selecting conditions for a product acceptance test are then discussed. Finally, we discuss the suitability of LRM-1 for use as a standard test material.

\section{A. Effects of Varying Test Parameters}

In order to develop a statistically-based set of criteria from which the most reproducible PAT can be selected, we need to identify sources of systematic bias and decouple these from sources of random experimental variation. In the absence of these sources of bias, the most reproducible test should be the test with the smallest amount of random error or "intrinsic variability." It must be noted, however, that it may not be possible in practice to completely decouple all of the potential sources of bias from random experimental error. 
To facilitate this process, all other potential sources of bias were minimized. The same scientists performed specific steps associated with preparing test components, executing individual steps of the tests, and analyzing the solutions to minimize variance in those aspects of the tests. The effects of varying temperature, glass/water mass ratio, and test duration were distinguished from each other by design of the testing and analytical matrix. The test matrix was designed with three sets of triplicate tests to help distinguish the between-day variability from the within-day variability. The solutions from some tests were analyzed on different days to determine if day-to-day variability of solution analysis is a significant source of variability. Understanding the relative importance of each source of variability should allow us to select those conditions that will provide the least total uncertainty. While the leachate solutions were analyzed for the majority of the elements that are present in the glass, we focus our statistical analysis on the elements that are specified in the TWRS-PCs, namely, $\mathrm{Na}, \mathrm{Si}$, and $\mathrm{B}$.

\section{Causes of Systematic Differences in Mean PAT Response}

Temperature, glass/water mass ratio, and test duration are all known to affect the mean response of glass durability tests. In the following section, we test the null hypothesis for each of these factors to statistically determine the effect that these factors have on the mean PAT response by using one-way ANOVA. Initially, we compare all of the fixed-effect factors simultaneously to determine the relative effect of each factor. Each factor is then examined individually. The purpose of these tests is to (1) establish the significance of each factor and (2) help identify other "hidden" factors that affect the reproducibility of these PATs.

\section{a. Analysis of Variance: All Factors}

Table 14 shows the results of ANOVA of $\mathrm{Na}, \mathrm{Si}$, and $\mathrm{B}$ concentrations with respect to all of the fixed-effect factors: temperature, glass/water mass ratio, test duration, and day-to-day variability (identified as triplicate). The P-value (Prob. $>$ F) for each fixed-effect factor are listed in the ANOVA table in the section "Effect Test" in the column "Prob.>F." We consider a $\mathrm{P}$-value $<0.05$ as evidence that the fixed-effect factor significantly affects the mean response of the PAT. Based on the calculated P-values, temperature and glass/water mass ratio significantly affect the concentrations of $\mathrm{Na}, \mathrm{Si}$, and $\mathrm{B}$ on these PATs (calculated P-values $<0.0001$ for temperature and for glass/water mass ratio for all three elements). Duration significantly affects the concentrations of $\mathrm{Si}$ (P-value 0.0001 ), but its affect on $\mathrm{Na}$ and $\mathrm{B}$ concentrations is only possibly significant ( $\mathrm{P}$-values 0.0851 and 0.0767 , respectively). The effect of day-to-day variability on the concentrations of $\mathrm{Na}, \mathrm{Si}$, and $\mathrm{B}$ test is insignificant when compared to the effects of temperature, glass/water mass ratio, and test duration.

\section{b. Analysis of Variance: Glass/Water Mass Ratio}

Table 15a-c lists the mean concentrations of $\mathrm{Na}, \mathrm{Si}$, and $\mathrm{B}$, and results of ANOVA of mean concentrations for PATs run with glass/water mass ratios of 1:1 and 1:10. As expected, 
tests run at a glass/water mass ratio of 1:1 generate solutions with significantly higher concentrations of $\mathrm{Na}, \mathrm{Si}$, and $\mathrm{B}$ than tests run at a glass/water mass ratio of 1:10 for every combination of temperature and duration that was evaluated. One-way ANOVA tables for replicate tests conducted under each set test conditions are given in Appendix D. In all cases, the precision of these tests is high enough to enable us to differentiate between tests run with glass/water mass ratios of $1: 1$ and 1:10 (i.e., all P-values are $<0.05$ ).

\section{c. Analysis of Variance: Temperature}

Tables 17a-c list mean concentrations of $\mathrm{Na}, \mathrm{Si}$, and $\mathrm{B}$, and results of ANOVA of mean concentrations from PATs run at $20^{\circ} \mathrm{C}, 40^{\circ} \mathrm{C}$, and $70^{\circ} \mathrm{C}$. As expected, tests run at higher temperatures generate solutions with significantly higher concentrations of $\mathrm{Na}, \mathrm{Si}$, and $\mathrm{B}$ for every combination of glass/water mass ratio and duration that was evaluated. One-way ANOVA tables for each set of test conditions are given in Appendix E. In all cases, the precision of these tests is high enough to enable us to differentiate tests run at $20^{\circ} \mathrm{C}, 40^{\circ} \mathrm{C}$, and $70^{\circ} \mathrm{C}$ (i.e., all $\mathrm{P}-$ values are $<0.05$ ).

\section{d. Analysis of Variance: Test Durations}

Table 17 lists the mean $\mathrm{Na}, \mathrm{Si}$ and $\mathrm{B}$ concentrations for replicate tests and ANOVA results of comparisons of mean concentrations for tests run for three and seven days. As expected, tests run for seven days generate solutions with higher concentrations of $\mathrm{Na}$, $\mathrm{Si}$, and $\mathrm{B}$ than do three-day tests for every combination of glass/water mass ratio and temperature that was evaluated. These comparisons reveal statistically significant differences for $\mathrm{Na}$ and $\mathrm{Si}$ for every combination of test parameters (i.e., $\mathrm{P}$-values are $<0.05$ ). The $\mathrm{B}$ concentrations are statistically significant in tests run at $40^{\circ} \mathrm{C}$ and $70^{\circ} \mathrm{C}$, the $\mathrm{B}$ concentrations in three- and sevenday tests at $20^{\circ} \mathrm{C}$ and glass/water mass ratios of $1: 1$ and $1: 10$ do not differ significantly (i.e., Pvalues are $>0.05$ ), primarily because of the low concentrations of $B$ generated under those test conditions. The precision of these tests is not high enough to differentiate between $B$ concentrations generated in tests run for three and seven days. One-way ANOVA tables for each set of test conditions are given in Appendix F.

The results of these statistical analyses support the well-known fact that the concentrations of glass components in solution from product consistency type tests correlate with temperature, duration, and glass/water mass ratio. An important factor that we consider next is the day-to-day-variability in test execution introduced when tests are initiated and terminated on different days.

\section{e. Analysis of Variance: Test Initiation/Termination Dates}

Table 18 lists mean $\mathrm{Na}, \mathrm{Si}$ and $\mathrm{B}$ concentrations for each set of triplicate tests conducted under each set of test conditions and the ANOVA results for comparison of mean concentrations for each of the three triplicate tests. These comparisons reveal several instances in 
which the mean responses of triplicate tests run under identical test parameters but run on different days differ from each other. Significant differences in $\mathrm{Na}$ response among the individual triplicate replicates $(\mathrm{P}$-values $<0.05$ ) are seen for tests $\mathrm{P}-\mathrm{B}-\mathrm{T}, \mathrm{P}-\mathrm{D}-\mathrm{T}, \mathrm{P}-\mathrm{F}-\mathrm{T}, \mathrm{P}-\mathrm{G}-\mathrm{T}$, and P-H-T. Significant differences in $\mathrm{Si}$ response among the individual triplicate replicates are seen for tests designated P-B-T, P-C-T, P-D-T, P-G-T, P-H-T, P-J-T, and P-L-T. Significant differences in B response among the individual triplicates are seen for all tests except P-E-T and P-F-T. There does not appear to be a direct correlation between those sets of triplicate tests with significant differences and the test parameters temperature, glass/water mass ratio, and duration. Significant differences are observed among tests run at $20^{\circ} \mathrm{C}, 40^{\circ} \mathrm{C}$, and $70^{\circ} \mathrm{C}$, in tests run with glass/water mass ratios of 1:1 and 1:10, and in tests run for three and seven days. The fact that we observe statistically significant differences in the $\mathrm{Na}, \mathrm{Si}$, and $\mathrm{B}$ concentrations between sets of identically performed triplicate tests emphasizes two important points: (1) the precision of any set of triplicate tests that are initiated and terminated together is higher than the overall precision when tests were initiated and terminated on different days and (2) some other "hidden" factor(s) that has a significant impact on the response of individual PATs impact the tests run on different days. One-way ANOVA tables for each comparison are given in Appendix G.

The potentially significant factor that we have not taken into account is the variability introduced during analysis of samples. The differences in the mean responses of sets of triplicate tests may be primarily due to the fact that each set of three test solutions derived from replicate tests was analyzed on a different day. The differences between the mean responses of each triplicate set of tests may be due entirely to day-to-day variability of solution analysis and not day-to-day variability in test performance.

\section{f. Analysis of Variance: Solution Reanalyses}

To estimate the uncertainty due to day-to-day variability of solution analysis, solutions from tests P-B-T, P-C-T, P-H-T, and P-I-T were reanalyzed. These solutions were generated from three- and seven-day tests run at $40^{\circ} \mathrm{C}$ and $70^{\circ} \mathrm{C}$ with a glass/water mass ratios of 1:10. The reanalyses were performed for these solutions and only for $\mathrm{Si}$ and $\mathrm{Na}$ because enough solution remained from only these tests. Solutions from these tests were analyzed in two identical analysis procedures with identical standards. The only difference is that they were analyzed on different days. . Tables $20 \mathrm{a}$ and $20 \mathrm{~b}$ lists mean concentrations and results of ANOVA comparison of the mean concentrations from duplicate analyses. Results for $\mathrm{Na}$ indicate the significant impact that analysis variability has on the overall variability of a PAT. Three of the four sets of solutions reanalyzed gave significantly different mean $\mathrm{Na}$ concentrations. The relative errors for the two sets of analyses ranged from 0.00 to $7.83 \%$. No such significant differences were observed for the two sets of Si analyses even though the relative errors ranged from -2.42 to $6.48 \%$. Similar relative errors are observed for $\mathrm{Na}$. Silicon determinations with ICP-MS suffer from a lack of precision due to the presence of molecular isobaric interferences (e.g., from $\mathrm{N}_{2}^{+}$and $\mathrm{CO}^{+}$). This lack of precision increases the variance within each set of analyses that masks the variance between the two sets of analyses. The higher relative precision of the $\mathrm{Na}$ determinations allows us to readily observe systematic day-to-day 
variations in the analysis of these samples. One-way ANOVA tables for each comparison are given in Appendix H. Apparently, day-to-day variability in the analysis of test solutions is a significant source of bias and, therefore, test variability.

The factors of temperature, glass/water mass ratio, and test duration all have significant impact on the mean response of a PAT. While this conclusion may, on the surface appear to be trivial, the systematic statistically based testing of these factors have allowed us to establish the significant effect that solution analysis procedure have on mean PAT response. All of this information influences identification of the optimal set of standard testing parameters.

\section{Intrinsic Test Variance}

We have used the percent relative standard deviation (\% rsd) calculated from the replicate tests to compare the variance in the response of the different tests. Table 20 summarizes the \% rsd values of the measured concentrations of $\mathrm{Na}, \mathrm{Si}$, and $\mathrm{B}$ in replicate tests with respect to the effects of test duration, glass/water mass ratio, and temperature. Several observations can be made with regard to statistics reported in Table 20a-c. The \% rsd of the concentration of $\mathrm{Na}$ tends to be invariant with respect to the three testing parameters being evaluated. There is a subtle indication that the measured concentration of $\mathrm{Si}$ is less reproducible in the $20^{\circ} \mathrm{C}$ test than in the 40 or $70^{\circ} \mathrm{C}$ tests. The reproducibility of the $\mathrm{B}$ concentration appears to be correlated with the test temperature. Another observation is that, for a given set of testing parameters, the \% rsd of the measured concentrations is element-dependent and increases in the order of $\mathrm{Na}<\mathrm{Si}<\mathrm{B}$.

All of these observations can be explained by an inverse correlation between the \% rsd and the concentration of an element in the analyzed solution. Elements in solution at high concentrations can typically be analyzed with higher accuracy and precision than elements present in solution at low concentrations. However, this trend can be obscured because solutions with elemental concentrations greater than approximately $10 \mathrm{mg} / \mathrm{L}$ need to be diluted prior to determination by ICP-MS. This is due to the fact that ICP-MS is designed primarily to measure trace components in solution and has an upper limit to its linear range. Dilution factors employed for analysis of $\mathrm{Na}$ and $\mathrm{Si}$ and were noted Section II. The important effect of dilution for solution analysis is demonstrated by the relatively high \% rsd measured for the $\mathrm{Na}$ and $\mathrm{Si}$ concentration in tests P-F-T and P-L-T $\left(70^{\circ} \mathrm{C}, 1: 1\right.$ mass ratio, three and seven days, respectively). While these tests generated the highest overall solution concentrations in the leachates, a dilution factor of 100 was used in the analysis of $\mathrm{Na}$ and $\mathrm{Si}$ so that the resulting concentrations of the solutions that were analyzed were lower than the concentrations attained in the $20^{\circ} \mathrm{C}$ tests. Consequently, the variances were higher. To graphically illustrate the inverse correlation between concentration of the analyzed solution and relative standard deviation, we have plotted the as-analyzed concentrations of $\mathrm{Na}, \mathrm{Si}$, and $\mathrm{B}$ with respect to \% rsd of the nine replicate tests for all tests in Figures 4-6. The data for each plot has been fit with a line calculated with linear regression. All three plots indicate a potential inverse correlation between the as-analyzed concentration and \% rsd for the nine replicates run under each set of test 
conditions. This correlation is possibly significant only for $\mathrm{Na}$ and $\mathrm{Si}$. All three figures show an apparent step function with lower \% rsd for replicate analysis at concentrations greater than approximately $1 \mathrm{mg} / \mathrm{L}$. Tests that generate solutions with $\mathrm{Na}$, $\mathrm{Si}$, and $\mathrm{B}$ concentrations $\geq 1 \mathrm{mg} / \mathrm{L}$ apparently can be analyzed much more reliably in our with the instrument settings used for these tests. The results illustrated in Figures 4-6 demonstrate the significant impact that the analysis procedure has on the overall reproducibility of these PATs.

To determine which set of parameters results in the lowest intrinsic random variability, it is necessary to deconvolute all sources of systematic variances from the data set and compare the tests strictly on the basis of variance. We have shown previously that test temperature, glass/water mass ratio, duration, and day-to-day variation in sample analysis all have a significant systematic effect on PAT response. To eliminate these factors, we renormalized the $\mathrm{Na}$, $\mathrm{Si}$, and $B$ concentrations to the mean of the triplicate tests that were initiated, terminated, and analyzed concurrently of those tests. Now we can compare, for example, the standard deviation of the 54 tests performed with glass/water mass ratios 1:1 to the 54 tests performed with glass/water mass ratios 1:10 and determine if the standard deviation of one of the glass/water mass ratios is intrinsically less variable. We did this on an element-by-element basis with the F-test. Results are given in Table 21. Plots corresponding to each comparison are given in Appendix I. Table 21 gives the standard deviation for each of the levels of the fixed-effect factors considered and the calculated F-statistic for the pair of standard deviations that are being compared. The critical Fstatistic for comparing of the two glass/water mass ratios and the two durations at the $95 \%$ significance level is 1.59; the critical F-statistic for comparing of each pair of test temperatures at the $95 \%$ confidence level is 2.16 [NETER-1988]. Interestingly, these comparisons indicate that none of the parameters that are considered here possess a significantly different intrinsic variability for $\mathrm{Na}$ and $\mathrm{Si}$. The only significant difference revealed by this analysis is that solutions from the tests run at a glass/water mass ratio of $1: 10$ have a significantly lower $B$ variability than the solutions from 1:1 tests. This one significant difference out of a total of 15 tests could be explained by chance alone.

The results of the statistical hypothesis testing that we have performed lead us to the conclusion that the primary factors that influence the reproducibility of PAT response are the analytical protocols used to determine the elemental concentrations in the leachates.

\section{B. Calculation of Glass Dissolution Rate}

Although the TWRS-PCs require that the release of $\mathrm{Si}, \mathrm{Na}$, and $\mathrm{B}$ be measured in the PATs, the dissolution rate of glass need only be calculated based on the release of Si. Calculation of the dissolution rate of a glass from the results of any test, including the PAT, requires knowledge of the specific surface area of the glass. As described in Appendix I of the PCT procedure, the specific surface area of crushed glass can be estimated based on the mesh size fraction and the density of the glass by modeling the glass particles with simple geometric particles. For the $-100+200$ mesh fraction, the specific surface area can be estimated by modeling each glass grain as a cube having an edge equal to the arithmetic average of the sieve 
sizes. The 100 mesh sieve has an opening of $150 \mu \mathrm{m}$ and the 200 mesh sieve has an opening of $75 \mu \mathrm{m}$ (U.S. Standard designation), so the average is $112 \mu \mathrm{m}$. The volume of a cube having an edge of $112 \mu \mathrm{m}$ is $1.4 \times 10^{-6} \mathrm{~cm}^{3}$ and the surface area is $7.5 \times 10^{-4} \mathrm{~cm}^{2}$. Since the measured density of LRM-1 is $2.52 \mathrm{~g} / \mathrm{cm}^{3}$, the mass of each cube is $3.5 \times 10^{-6} \mathrm{~g}$ and the specific surface area is $2.1 \times 10^{2} \mathrm{~cm}^{2} / \mathrm{g}$, or $2.1 \times 10^{-2} \mathrm{~m}^{2} / \mathrm{g}$. Modeling each glass grain as a sphere with a diameter of $112 \mu \mathrm{m}$ yields essentially the same specific surface area. For a test conducted with $1 \mathrm{~g}$ of glass in $10 \mathrm{~mL}$ of water, the glass surface area/solution volume $(\mathrm{S} / \mathrm{V})$ ratio is $2100 \mathrm{~m}^{-1}$. For a test conducted with $5 \mathrm{~g}$ of glass in $5 \mathrm{~mL}$ of water, the $\mathrm{S} / \mathrm{V}$ ratio is $21,000 \mathrm{~m}^{-1}$.

The average normalized dissolution rate of a glass is calculated by dividing the mass of an element released to solution by the product of the surface area of glass, the mass fraction of that element in the glass, and the test duration. Alternatively, the dissolution rate can be calculated by dividing the concentration of an element in solution by the product of the $\mathrm{S} / \mathrm{V}$ ratio, the mass fraction of that element in the glass, and the test duration. Equations 1 and 2 give equivalent forms of the normalized rate equation:

$$
\begin{gathered}
N R(i)=m_{i} /\left(S \bullet f_{i} \bullet t\right) \\
N R(i)=c_{i} /\left((S / V) \bullet f_{i} \bullet t\right)
\end{gathered}
$$

where $m_{i}$ is the mass of element $i$ in solution, $c_{i}$ is the concentration of element $i$ in solution, $S$ is the surface area of glass in the test, $(S / V)$ is the glass surface area-to-solution volume ratio, $f_{i}$ is the mass fraction of $i$ in the glass, and $t$ is the test duration. Note that the rate calculated in this way is an average rate over the entire test duration and is not an intrinsic property of the glass. The rates calculated from the average concentrations measured in replicate tests are presented in Table 22. The values of $f(i)$ used to calculate the rates were computed from the analyzed glass composition in Table 1. These values are as follows: $f(N a)=0.127, f(S i)=0.250, f(B)=0.0252$, $f(A l)=0.0508$, and $f(K)=0.0100$. The values of $S / V$ were $2100 \mathrm{~m}^{-1}$ for tests at a glass/water mass ratio of $1: 10$ and $21000 \mathrm{~m}^{-1}$ for tests at a glass/water mass ratio of $1: 1$.

The dissolution of a silicate glass is known to depend on the glass composition, temperature, and solution chemistry, particularly the $\mathrm{pH}$ and activity of orthosilicic acid [MCGRAIL-1997]. Evolution of the solution $\mathrm{pH}$ and the orthosilicic acid concentration during the test will affect the dissolution rate. In general, the observed dissolution rate of a glass will decrease with the reaction time and with the $\mathrm{S} / \mathrm{V}$ ratio of the test because the buildup of orthosilicic acid, and perhaps other dissolved glass components. Tests with LRM-1 glass show this behavior. As can be seen in that rates in Table 22, when the other variables are fixed, the average dissolution rate for the tests increases with the test temperature, and decreases with the glass/water mass ratio, and the test duration in most cases. Exceptions to these trends occur when differences in the solution $\mathrm{pH}$ values overwhelm the other effects. For example, the rate based on $\mathrm{Si}$ in tests conducted at $20^{\circ} \mathrm{C}$ and a mass ratio of $1: 1$ is higher than in the tests at a mass ratio of $1: 10$ because the $\mathrm{pH}$ is significantly higher in the tests at a ratio of $1: 1$. In other tests, the 
effects of dissolved glass components is greater than the effect of the $\mathrm{pH}$. For most glasses, the rate increases by a factor of 2.5 for each unit of increased $\mathrm{pH}$.

\section{Comparison of Tests at Different Temperatures}

The TWRS-PCs permit the Contractors to measure the normalized release at a temperature higher than $20^{\circ} \mathrm{C}$ if the response at the higher temperature can be related to the response at $20^{\circ} \mathrm{C}$. The effect of temperature on the response in static tests cannot be separated from the effects of changes in the $\mathrm{pH}$ and orthosilicic acid without knowing the values for several parameters for dissolution of the glass being tested, including the intrinsic dissolution rate, the activation energy, the pH-dependence, and the quasi-equilibrium constant of the glass [MCGRAIL-1997]. These values must be determined in separate experiments.

An empirical relationship may exist that could be used to relate test responses measured at different temperatures. Comparison of the results of our tests conducted at 20,40 , and $70^{\circ} \mathrm{C}$ provides insight into how such an empirical relationship might be demonstrated. The following discussion is included to provide insight into the uncertainties associated with extrapolating the results of PATs to lower temperatures. Figure 7 shows the mean values of NR(Si) for tests conducted for three and seven days at glass/water mass ratio of 1:10 and 1:1 (which are estimated to provide $\mathrm{S} / \mathrm{V}$ ratios of 2100 and $21,000 \mathrm{~m}^{-1}$, respectively) at 20,40 , and $70^{\circ} \mathrm{C}$ plotted against the inverse absolute temperature in an Arrhenius plot. Lines are drawn between the data under each set of time and mass ratio conditions to guide the eye. The observation that the rates measured at 70 and $40^{\circ} \mathrm{C}$ decrease as the reaction time and the $\mathrm{S} / \mathrm{V}$ ratio increase indicates that the decrease in rate is probably due to the effect of dissolved glass components (primarily orthosilicic acid) on the glass dissolution rate. Extrapolation of test results at $70^{\circ} \mathrm{C}$ and at $40^{\circ}$ to $20^{\circ} \mathrm{C}$ overestimates the measured dissolution rate at $20^{\circ} \mathrm{C}$ under all test conditions. For example, extrapolation of the results of tests conducted for seven days at $2100 \mathrm{~m}^{-1}$ and $20^{\circ} \mathrm{C}$ predicts a dissolution rate of about $0.8 \times 10^{-3} \mathrm{~g} /\left(\mathrm{m}^{2} \bullet \mathrm{d}\right)$, but the measured dissolution rate is $0.280 \times 10^{-3}$ $\mathrm{g} /\left(\mathrm{m}^{2} \cdot \mathrm{d}\right)$. The activation energy calculated for the seven-day $2100 \mathrm{~m}^{-1}$ tests at 40 and $70^{\circ} \mathrm{C}$ is only $38 \mathrm{~kJ} / \mathrm{mol}$ while the activation energies for dissolution of most glasses are near $80 \mathrm{~kJ} / \mathrm{mol}$. This value is significantly lower than what has been measured for the dissolution of similar glasses with flow-through apparatuses [MCGRAIL-1997]. The cause is the influence of dissolved glass components on the dissolution rate, which is much greater in these tests than in flow-through tests. In other words, the dissolution rates measured in these static tests are much less than the forward dissolution rate of LRM-1 glass. Again, while the dissolution rate of LRM1 does not represent a performance benchmark for LAW glasses, it is important to note that the rate measured in the PAT is strongly affected by the buildup of dissolved glass components. A similar effect will probably occur in tests with all glasses. The activation energy calculated from the results of tests conducted at 40 and $20^{\circ} \mathrm{C}$ in seven-day tests at a glass/mass ratio of $1: 10$ is about $78 \mathrm{~kJ} / \mathrm{mol}$, which is much better agreement with the activation energies for borosilicate glasses measured in flow-through tests. 
Figure 8 shows the effect of temperature on the dissolution rates calculated from the solution concentrations of $\mathrm{B}, \mathrm{Na}$, and $\mathrm{Si}$ in tests conducted for seven days at a glass/water mass ratio of $1: 10\left(\mathrm{~S} / \mathrm{V}\right.$ ratio of about $\left.2100 \mathrm{~m}^{-1}\right)$ at 20,40 , and $70^{\circ} \mathrm{C}$. The rates based on $\mathrm{B}$ and $\mathrm{Si}$ are essentially identical in tests conducted at 20 and $40^{\circ} \mathrm{C}$, but the release of $\mathrm{B}$ is slightly at $70^{\circ} \mathrm{C}$. The release of $\mathrm{Na}$ is significantly higher than the release of either $\mathrm{B}$ or $\mathrm{Si}$ at all temperatures; it is about ten times higher than the release of $\mathrm{Si}$ in tests at $20^{\circ} \mathrm{C}$. Similar release behavior of $\mathrm{B}, \mathrm{Na}$, and $\mathrm{Si}$ has been observed to persist several years in tests conducted at these temperatures with a similar glass [BAKEL-1995]. The preferential release of Na in those tests was attributed to an ion exchange reaction that resulted in the release of $\mathrm{Na}$, but not $\mathrm{B}$ or $\mathrm{Si}$. The release of $\mathrm{B}$ and $\mathrm{Si}$ occurs through a hydrolysis reaction, which is significantly slower than ion exchange at low temperatures. A similar mechanism is probably operative during the dissolution of LRM-1 glass.

\section{Use of LRM-1 as a Standard Test Material}

The use of LRM-1 glass as a test standard is being considered. In this capacity, samples of the LRM-1 glass would undergo the PATs simultaneously with waste products. That is, tests with LRM-1 would be conducted in vessels that were cleaned in the same batch as those used for tests with the waste product, assembled at the same time, and placed in the same oven and the leachates analyzed with the same technique simultaneously as those from tests with the waste product. The responses measured in the tests with LRM-1 glass would be used to verify that the tests were conducted properly and that nothing occurred during execution of the tests or analyses that invalidates the results of tests with the waste product. The performance of the test and analyses would be validated if the response of the tests with LRM- 1 fall within the specified acceptance range. That range would be determined from the results of a round robin test program.

The glass must meet several requirements for use as a standard test material. The response of the glass in the PATs must be well-characterized and the acceptable range determined. That range must take into account the variations in the response of the glass and interlaboratory variations in the analysis of the leachate solutions. The LRM-1 glass was made for tests conducted at ANL to measure the intralaboratory precision of tests and in the round robin program to measure interlaboratory precision. A large source of homogeneous material must be procured for use as the standard material during waste immobilization. The composition of that glass may closely match that of LRM- 1 if it is deemed acceptable as a standard material.

The glass must also remain chemically stable; that is, its response in the test must remain within the range of acceptability as the material ages. Its stability must be verified by periodic testing and tracking the test results to detect any change in the response. Since the glass contains only small amounts of redox-sensitive elements, the response of the glass should not change significantly over time. Although the standard test glass is not intended for use as a performance standard, its documented behavior in other tests and analyses that may be required for waste products may also support its use as a standard for measurement of the ANS/ANSI 16.1 leachability index of sodium and the response in the TCLP. The glass could also be used as a 
composition standard to verify that the compositions of waste products (except for radionuclides) are being accurately analyzed at contractor laboratories. Other materials are available for use as density and compressive strength standards.

\section{E. Evaluation of the Adequacy of the Specified Test Method}

Finally, we have used these test results to evaluate the adequacy of the test specified in the TWRS-PCs for measuring the glass dissolution rate for acceptance testing of ILAW products. We did this by objectively comparing the precision of tests run under those conditions with that of tests run under other conditions to identify the set of parameter values that provide the most reliable measure of the dissolution rate, and by applying experimental and analytical insight to considering potential complexities associated with using particular test conditions, analytical limitations, etc. We have demonstrated by these tests that the total uncertainty in the responses under the range of test conditions that were evaluated is dominated by analytical uncertainty. For this reason, the test parameters for an acceptance test should be selected in part on the basis of the ease with which the solutions that are generated can be analyzed. The results must also remain consistent with contractual requirements. In general, the precision of the tests increased with temperature, glass/water mass ratio, and test duration, primarily because of the higher analytical precision that can be attained for solutions with higher analyte concentrations.

We have observed that solutions with $\mathrm{Na}, \mathrm{Si}$, and $\mathrm{B}$ concentrations $>1 \mathrm{mg} / \mathrm{L}$ can be analyzed much more reliably in our laboratory than solutions with lower concentrations. This observation is dependent on two factors: analytical instrumentation and laboratory cleanliness. We analyzed solutions with ICP-MS. The LOQs for $\mathrm{Na}$, $\mathrm{Si}$, and $\mathrm{B}$ with the ICP-MS used in this study are generally $<0.1 \mathrm{mg} / \mathrm{L}$. These LOQs are generally superior to those analytical instruments typically found in contract analytical laboratories, such as graphite furnace atomic absorption spectrometry (GFAAS) and flame atomic absorption spectrometers (FAAS). However, ICP-MS is an expensive technique that requires a highly trained scientist for even routine analyses. It is, therefore, less likely to be available in many contract laboratories. Inductively coupled plasma-atomic emission spectrometry is a general purpose technique that offers sufficient sensitivity for most elements, particularly $\mathrm{Na}, \mathrm{Si}$, and $\mathrm{B}$. It may even be considered to be superior to ICP-MS for determining elements with low molecular weight (e.g., $\mathrm{Na}, \mathrm{Si}$, and $\mathrm{B}$ ) due to the fewer spectral interferences and lower sensitivity to sample matrix. However, ICP-AES requires greater sample volume than GFAAS and also may also not be available in all contract laboratories. Graphite furnace atomic absorption spectrometry requires the smallest amount of sample for analysis of a single element but this technique is cumbersome and time-consuming a separate analysis must be made for each element. The low price of a GFAAS results in it's popularity in contract laboratories. Flame absorption atomic absorption spectroscopy is a rapid technique with good sensitivity for sodium and is readily available in contract laboratories. The requirement for large sample volumes may preclude this techniques use if analysis if elements other than $\mathrm{Na}$ is required. Inductively coupled plasma-atomic emission spectrometry is becoming more popular in contract laboratories and might offer a compromise to the relative advantages and disadvantages of these techniques. 
The second important analytical factor is laboratory cleanliness, which can influence test blanks. The PCT Method A procedure requires that the concentrations of monitored elements in test blanks be $<10 \%$ of the concentration of that element in the test solution for the results to be considered valid [ASTM-1994]. This criterion would be difficult to meet in tests on materials more durable than LRM-1 and in laboratories with high blank levels. Mean concentrations of test blanks for this work were approximately $0.1,<0.06$, and $<0.008 \mathrm{mg} / \mathrm{L}$ for $\mathrm{Na}, \mathrm{Si}$, and $\mathrm{B}$, respectively. If we apply the PCT-A criteria to this work, our PAT would have to generate solutions containing at least 0.6 , and $0.08 \mathrm{mg} / \mathrm{L}$, respectively. It should be noted that extreme care was taken to minimize analytical and experimental blanks in this work. This amount of attention to contamination cannot be anticipated for tests performed in contract laboratories. This criterion limits the applicability of the $20^{\circ} \mathrm{C}, 1: 10$, three- and seven-day tests. If a $20^{\circ} \mathrm{C}$ test were selected, it would have to be run with a glass/water mass ratio greater than 1:1 to ensure that concentrations sufficiently above laboratory experimental blanks are generated. The use of a higher glass/water mass ratio is not, however, without drawbacks. Increasing the glass/water mass ratio would increase the amount of glass required and decrease the amount of solution available for analysis. Both of these factors, along with potential problems with low solution concentration make the results of $20^{\circ} \mathrm{C}$ tests less reliable than those from tests conducted at higher temperatures.

Based on test results with LRM-1 glass test temperatures of 40 and $70^{\circ} \mathrm{C}$ are expected to provide responses having essentially the same level of precision for glasses with durabilities similar to LRM-1. An advantage of testing at $70^{\circ} \mathrm{C}$ is that high solution concentrations are generated in the leachate solution, so less sensitive analytical techniques can be used. Higher test solution concentrations increase the likelihood that results will be substantially higher than blank test results, which could become even more important if waste forms that are significantly more durable than LRM-1 are produced. The disadvantage of the higher solution concentrations attained at $70^{\circ} \mathrm{C}$ is that they affect the dissolution rate to a greater extent than tests at lower temperatures, so that extrapolation to $20^{\circ} \mathrm{C}$ would be less accurate than extrapolation of the results of $40^{\circ} \mathrm{C}$ tests. The accuracy of such an extrapolation is important, since the radionuclide release rate, and, hence, the acceptability of the waste form, is to be calculated from the rate at $20^{\circ} \mathrm{C}$. For LRM-1 glass, tests at a temperature that is between $20^{\circ} \mathrm{C}$ and $70^{\circ} \mathrm{C}$ (i.e., $40^{\circ} \mathrm{C}$ ) is a compromise between the need for high solution concentrations for analysis and the need for low concentrations to reduce the effect of the solution chemistry on the measured glass dissolution rate and so facilitate extrapolation to $20^{\circ} \mathrm{C}$. Another minor advantage of conducting tests at $40^{\circ} \mathrm{C}$ instead of at $20^{\circ} \mathrm{C}$ is that an incubator or oven can be used instead of a circulating water bath. Use of a water bath is less convenient than use of an oven, although a water bath does provide better temperature control.

Two other factors that are affected by selection of the glass/water mass ratio are the amount of glass that is needed to conduct the test and the amount of solution that is available for analysis. In general, the amount of sample that is used in the test should be large enough to ensure that it is representative of the material being tested, but not so large that obtaining material for testing or disposing of material after the test becomes burdensome. The amount of solution 
that is needed for analysis provides a greater constraint than the amount of glass. As we discussed previously, diluting of the leachate for analysis may significantly affect the uncertainty of that analysis. Small leachate volumes may require large dilution factors to produce enough sample for analysis with particular instruments. The availability of an analytical instrument that can simultaneously determine all of the required elements at low concentrations in samples of small volume is critical to the routine performance of the PAT. Therefore, a test that provides an ample amount of solution for analysis and high concentrations of analytes is preferred.

The glass/water ratio used in the test also affects the uncertainty in the computed glass dissolution rate because it affects the $S / V$ ratio of the test. Significant uncertainty remains in the calculation of the specific surface area of crushed glass, and smaller glass/water mass ratios and lower $\mathrm{S} / \mathrm{V}$ ratios reduce the impact of that uncertainty on the calculated glass dissolution rate. Like the test temperature, the glass/water ratio used in the PAT represents a compromise between the conflicting needs for high solution concentrations to minimize the uncertainties in the solution analyses and low solution concentrations to minimize the effect of the solutes on the measured glass dissolution rate. Although tests conducted at a glass/water mass ratio of 1:10 are consistent with the ratio specified in the PCT Method A procedure, this by itself is not a technical advantage. Overall, tests at a ratio of 1:10 are preferred because the larger volume of leachate solution that can be recovered from these tests facilitates solution analysis.

The test duration did not significantly affect the precision of the tests. However, higher solution concentrations were generated in 7-day tests than in 3-day tests under all test conditions. The longer test duration will, therefore, provide less analytical uncertainty to the measured dissolution rate. Test duration provides the same advantages of testing at higher temperature and higher mass ratio without the drawbacks. A test duration of 7 days is consistent with the TWRS-PCs and consistent with PCT Method A used for high-level waste glass products, although this is not a technical advantage.

Presuming that the requirement that the test response be related to the response at $20^{\circ} \mathrm{C}$ takes precedence over the requirement that $\mathrm{B}$ be analyzed, the optimum test conditions are a duration of seven days, a glass/water mass ratio of $1: 10$, and a temperature of $40^{\circ} \mathrm{C}$. This also presumes that other test requirements are consistent with the PCT Method A procedure: tests should be conducted with the $-100+200$ mesh glass, the glass should be washed with alcohol and demineralized water, tests should be conducted in Type 304L stainless steel vessels, and ASTM Type I water should be used as the leachant.

Finally, the PCT itself is a suitable test method for use in waste product acceptance. It has the advantage of already being a consensus standard method, has been accepted for use in glass consistency testing, is simple to perform, requires only one analysis per test, and provides a quantitative measure of glass dissolution. We recommend that tests be conducted at $40^{\circ} \mathrm{C}$ instead of $20^{\circ} \mathrm{C}$, at a mass ratio of 1:10, and for seven days. With LRM- 1 glass, tests at $40^{\circ} \mathrm{C}$ generated silicon solution concentrations about eight times higher than tests at $20^{\circ} \mathrm{C}$. We are presently conducting tests with other glasses that are representative of possible $\mathbb{L} A W$ products 
for DOE sites. These tests will provide evidence to further assess our conclusion that tests should be conducted at $40^{\circ} \mathrm{C}$ rather than $20^{\circ} \mathrm{C}$.

\section{SUMMARY}

We conducted laboratory tests to measure the effects of temperature, glass/water mass ratio, and test duration on the mean and standard deviation of response of LRM-1 glass in PCTlike tests. The results of these tests provide a data base that can be used to evaluate the credibility and validity of durability test results reported by the Private Contractors as part of the acceptance procedure for immobilized low-activity waste (ILAW) products. They also provide an evaluation of the adequacy of the test method specified in the contracts for use as a waste acceptance test. We have further characterized LRM-1 glass to evaluate its possible use as a chemical and physical property standard for use in ILAW product acceptance testing.

The glass was formulated and made at ANL to be representative of likely vitrified waste products with LAW from Hanford and other DOE sites. The glass was subjected to replicate tests in a statistically designed matrix to measure the effects of temperature $\left(20,40\right.$, and $\left.70^{\circ} \mathrm{C}\right)$, glass/water mass ratio (1:10 and 1:1), and test duration (three and seven days) on the glass response. In general, the results of tests conducted at higher temperatures, higher glass/water mass ratios, and longer durations had higher precision. However, the results indicated that the variability depended primarily on the concentrations in the solutions that were analyzed and the extent to which the leachate was diluted for analysis.

Measurement of the silicon release in the PCT is most important since that value is used to estimate the radionuclide release rates, for which maximum values are specified in the contracts. (Of equal importance are the measured amounts of key radionuclides in the glass. The uncertainties in those values were not addressed in this Task.) Therefore, we have focused on the measurement of the silicon solution concentrations in our evaluation of the adequacy of the test method specified in the privatization contracts. The silicon concentrations generated under test conditions that are specified in the TWRS-PCs (seven days at $20^{\circ} \mathrm{C}$ ) were only 8 and 17 times higher than the quantitation limit in tests conducted at glass/water mass ratios of $1: 10$ and $1: 1$, respectively. The acceptance test for high-level waste products requires that the concentrations be greater than $10 \mathrm{X}$ background for the test to be considered valid. Tests with the LRM-1 glass fail this criterion at a mass ratio of 1:10, and barely meet it at a mass ratio of 1:1. Since the background levels for our tests are probably much lower than can be expected for routine analyses at contractor laboratories, it is likely that measurement of the dissolution rates of some waste products, which may be more durable than LRM-1, cannot be quantified in tests conducted at $20^{\circ} \mathrm{C}$. At best, a maximum rate may be calculated based on the detection limit.

Several properties of the glass were measured to assess its compliance with requirements specified in the TWRS-PCs and its possible use as a standard material. The composition of the glass was measured by dissolving it in mineral acids and analyzing the solutions with ICP-MS, 
ICP-AES, and IC. The microstructure of the glass was examined with SEM and TEM to verify that the glass was not phase separated and that no phases had precipitated in the glass. The density of the glass was measured by buoyancy to be $2.52 \mathrm{~g} / \mathrm{cm}^{3}$. The compressive strength was measured to be $226 \pm 57 \mathrm{MPa}$. The average leachability index of sodium based on triplicate ANS/ANSI 16.1 tests was measured to be $15.3 \pm 0.1$. The glass passed the TCLP for all RCRAregulated elements that were added to the glass.

The results of these tests and analyses indicate that the LRM-1 glass would be a suitable standard material for use in waste product acceptance. We base this conclusion on the good precision of replicate tests and on the fact that the material properties meet the requirements for waste forms that are specified in the privatization contracts. While the LRM-1 glass is not a waste form and is not required to meet those requirements, we believe that the performance of a standard material should match closely that of the material of interest. In the capacity of an analytical test standard, for example, the glass could be provided to the contractors by DOE for the purpose of verifying the proper execution of tests and analyses at the laboratory in which the waste products are evaluated. Tests and analyses would be conducted simultaneously with LRM-1 and product glass. Demonstration that the results of tests and analyses with the LRM-1 glass were consistent with the results obtained elsewhere (such as the values we have measured in this study) would provide added confidence to the reported results of tests with the product glass. The use of LRM-1 glass would provide evidence regarding test execution, analytical limits, and laboratory background contamination levels. While service as an analytical standard for measurement of the glass corrosion rate is probably the most important need, the LRM-1 glass could also be used as a standard for ANSI/ANS 16.1 leach tests, for density measurements, and perhaps as a composition standard for most glass components, although it does not contain radionuclides and further analyses are warranted for this use. Depending on the tests for which it may be used as a standard, glass may be needed for crushed or monolithic samples. 


\section{ACKNOWLEDGMENTS}

We acknowledge the assistance of Lohman Hafenrichter in preparation of LRM-1 glass, Mark Surchik in the assistance in the execution of the PATs and ICP-MS analyses, and Allen Bakel in the performance of the VHTs. Roberta Riel served as Quality Assurance Coordinator. This work was supported by the U.S. Department of Energy, Office of Environmental Management, under contract W31-109-ENG-38, through the auspices of the Tanks Focus Area program under TTP CH27WT31. 


\section{VU. REFERENCES}

ANSI/ANS-1986

American National Standard for Measurement of the Leachability of Solidified Low-Level Radioactive Waste, American Nuclear Society, LaGrange, $\amalg$, ANSI/ANS-16.1 (1986).

ASTM D 1193-91

Standard Specification for Reagent Water, Standard D1193-91, American Society for Testing and Materials, Philadelphia, PA.

\section{ASTM-1993}

Standard Test Method for Density of Glass by Buoyancy, Standard C 693-93, American Society for Testing and Materials, Philadelphia, PA.

ASTM-1993a

Standard Test Method for Compressive Strength of Cylindrical Concrete Specimens, Standard C 39-93a, American Society for Testing and Materials, Philadelphia, PA.

\section{ASTM-1994}

Standard Test Method for Determining Chemical Durability of Nuclear Waste Glasses: The Product Consistency Test (PCT), Standard C1285-94, American Society for Testing and Materials, Philadelphia, PA.

\section{BAKEL-1995}

A. J. Bakel, W. L. Ebert, and J. S. Luo, Long-Term Performance of Glasses for Hanford Low-Level Waste, Ceram. Trans. Environmental and Waste Management Issues in the Ceramics Industry, Vol. 61, 515-522 (1995).

\section{CUNNANE-1994}

J. C. Cunnane, ed. J. K. Bates, C. R. Bradley, E. C. Buck, J. C. Cunnane, W. L. Ebert, X. Feng, J. J. Mazer, D. J. Wronkiewicz, J. Sproull, W. L. Bourcier, B. P. McGrail, and M. K. Altenhofen, High-Level Waste Borosilicate Glass: A Compendium of Corrosion Characteristics, United States Department of Energy Office of Waste Management Report DOE-EM-0177 (1994).

\section{CURRIE-1968}

L. A. Currie, 1968, "Limits for Qualitative Detection and Quantitative Determination," Anal. Chem. 40, 586-593. 
DOE-1996

U.S. Department of Energy, Tank Waste Remediation System (TWRS) Privatization Contract No. DE-AC06-RL13308 with British Nuclear Fuels Limited, Inc. (1996), and U.S. Department of Energy, Tank Waste Remediation System (TWRS) Privatization Contract No. DE-AC06-RL 13309 with Lockheed Martin Advanced Environmental Systems (1996).

\section{EBERT-1998}

W. L. Ebert, D. M. Strachan, and S. F. Wolf, Formulation of a Candidate Glass for use as an Acceptance Test Standard Material, Argonne National Laboratory Report ANL-98/10 (1998).

FR-1990

Toxicity Characteristic Leach Procedure, Federal Register March 29, 1990, pp. 1179811877 , and June 29, 1990, pp. 26986-26998.

\section{JANTZEN-1987}

C. M. Jantzen and N. E. Bibler, Product Consistency Test (PCT) for DWPF Glass: Part I. Test Development and Protocol, DPST-87-575, Savannah River Laboratory, Aiken, SC (1987).

MCGRAIL-1997

B. P. McGrail, W. L. Ebert, A. J. Bakel, and D. K. Peeler, "Measurement of Kinetic Rate Law Parameters on a Na-Ca-Al Borosilicate Glass for Low-Activity Waste," J. Nucl. Mater. 249, 175-189 (1997).

NETER-1988

J. Neter, W. Wasserman, and G. A. Whitmore, 1988, Applied Statistics, Third Edition, Allyn and Bacon, Inc.

STRACHAN-1994

D. M. Strachan, W. L. Bourcier, and B. P. McGrail, "Towards a Consistent Model for Glass Dissolution," Radioactive Waste Management and Environmental Restoration 19, 129-145 (1994). 


\section{FIGURES}

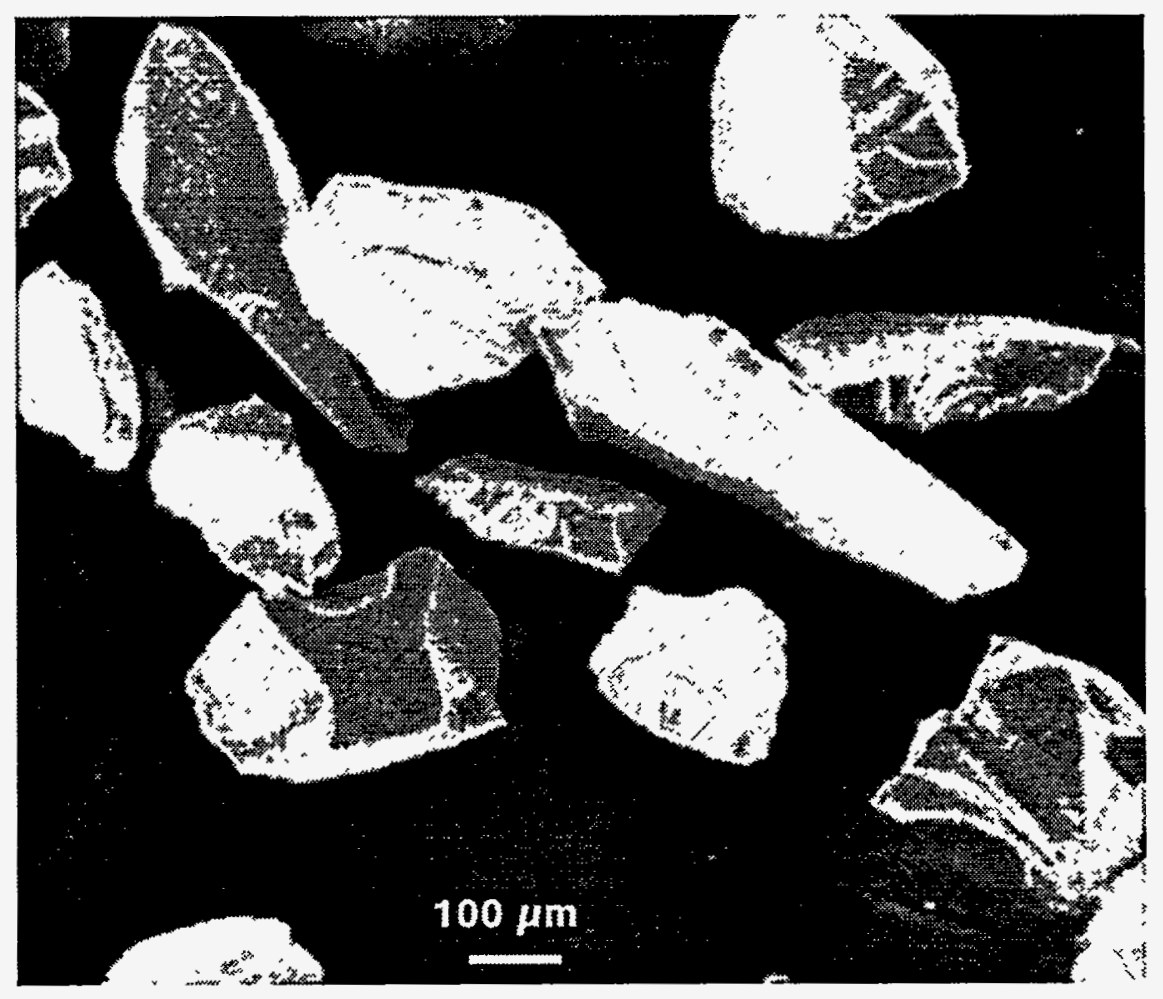

Figure 1. An SEM Photomicrograph of Several Particles of Clean -100 +200 Mesh LRM-1 


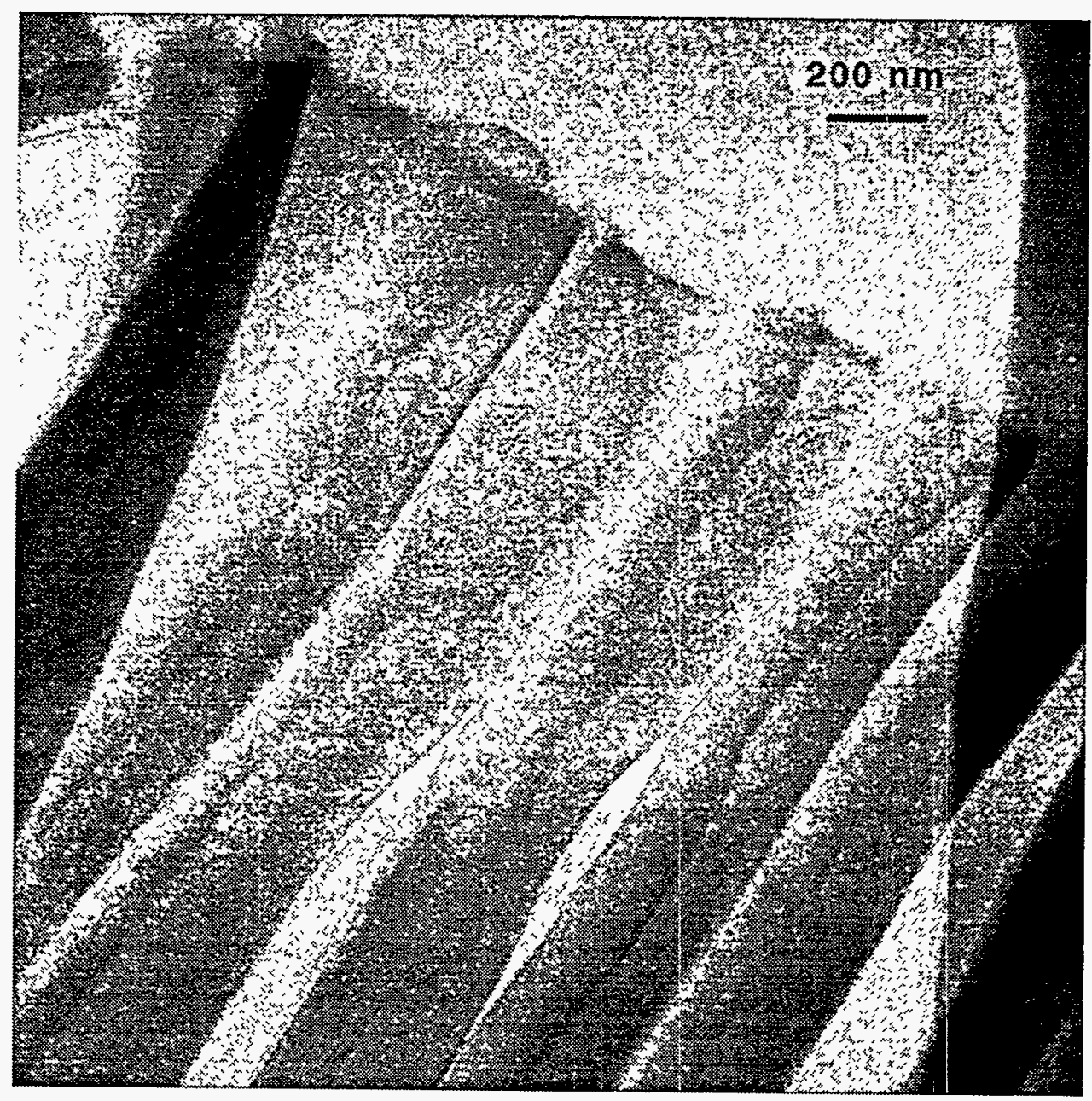

Figure 2. A TEM Photomicrograph of an Ultramicrotomed Section of LRM-1. No heterogenieties are observable. 


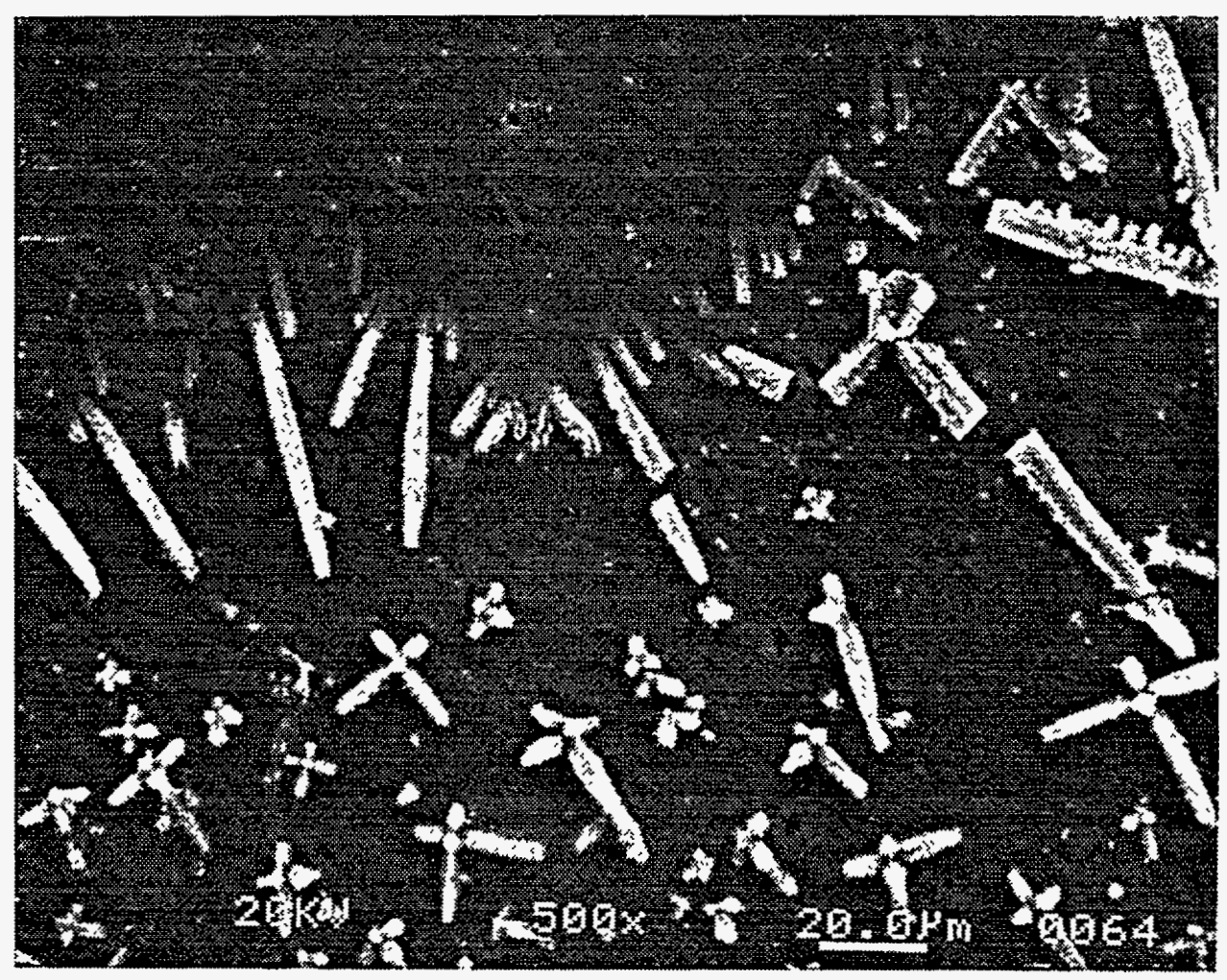

Figure 3. An SEM Image of Evaporite Crystals on the Surface of a 7-day Vapor-Reacted Sample of LRM-1 


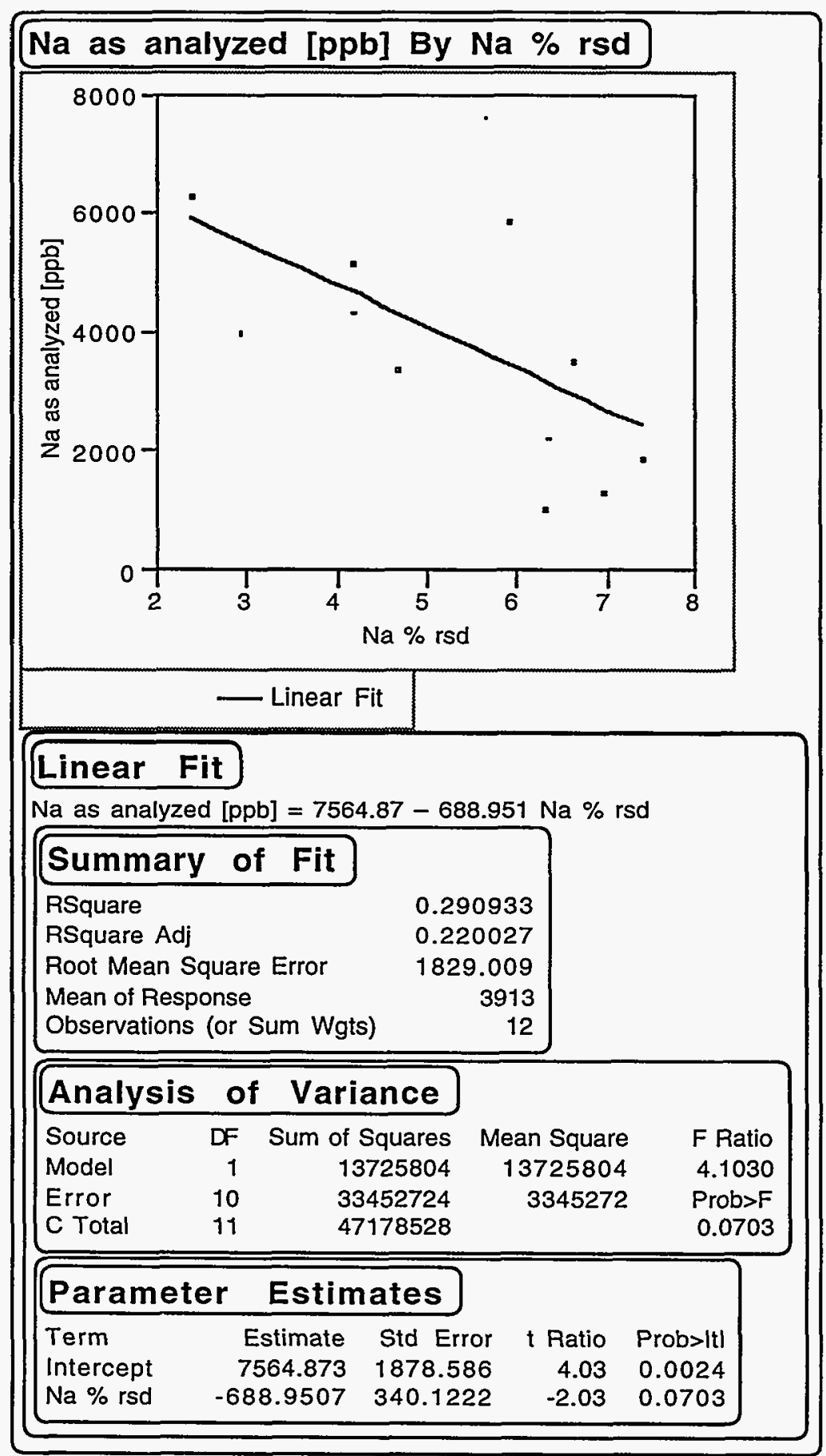

Figure 4. Linear Regression of the As-Analyzed Na Concentration vs. \% rsd of the Nine Replicates Performed for each of the 12 PATs 


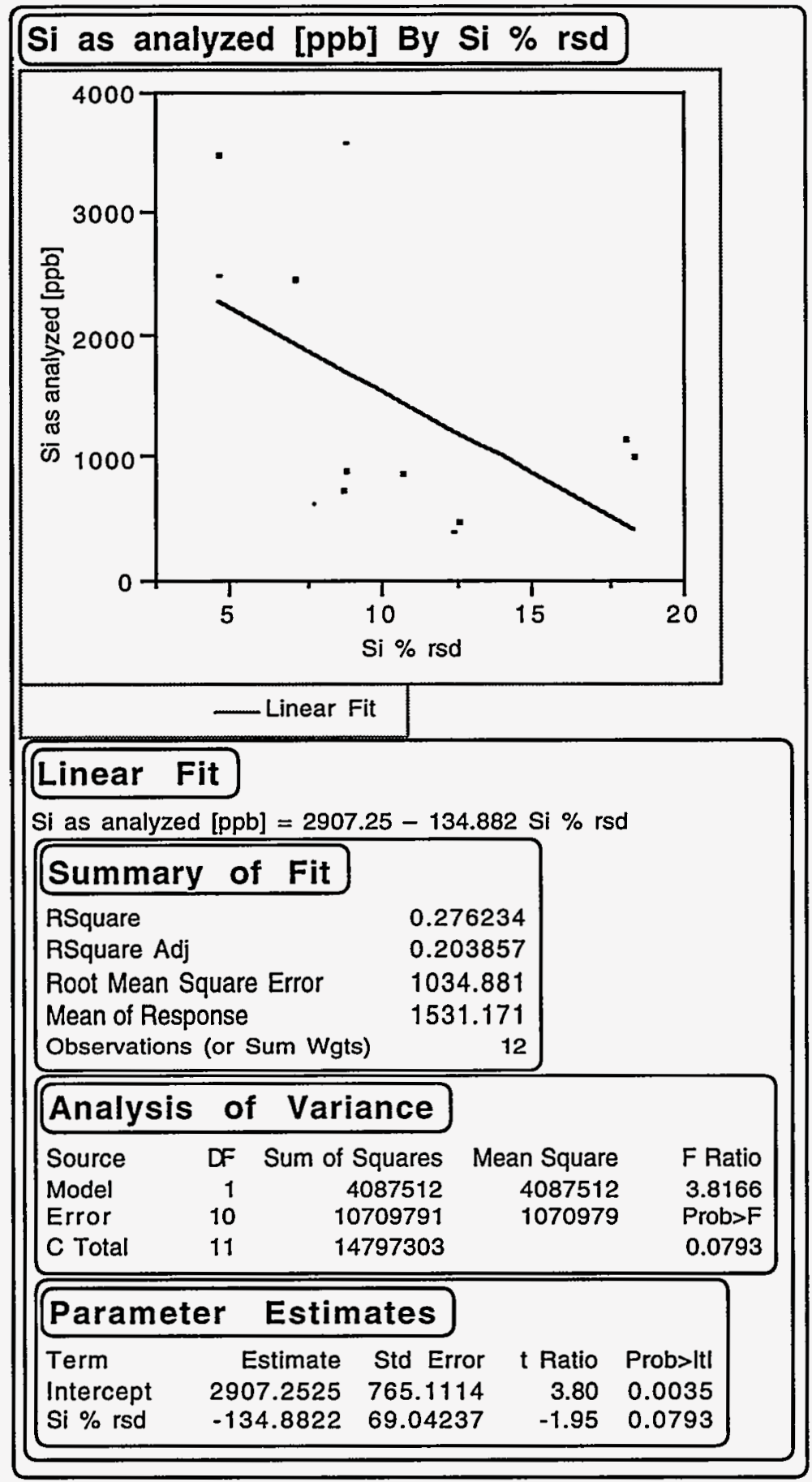

Figure 5. Linear Regression of the As-Analyzed Si Concentration vs. \% rsd of the Nine Replicates Performed for each of the 12 PATs 


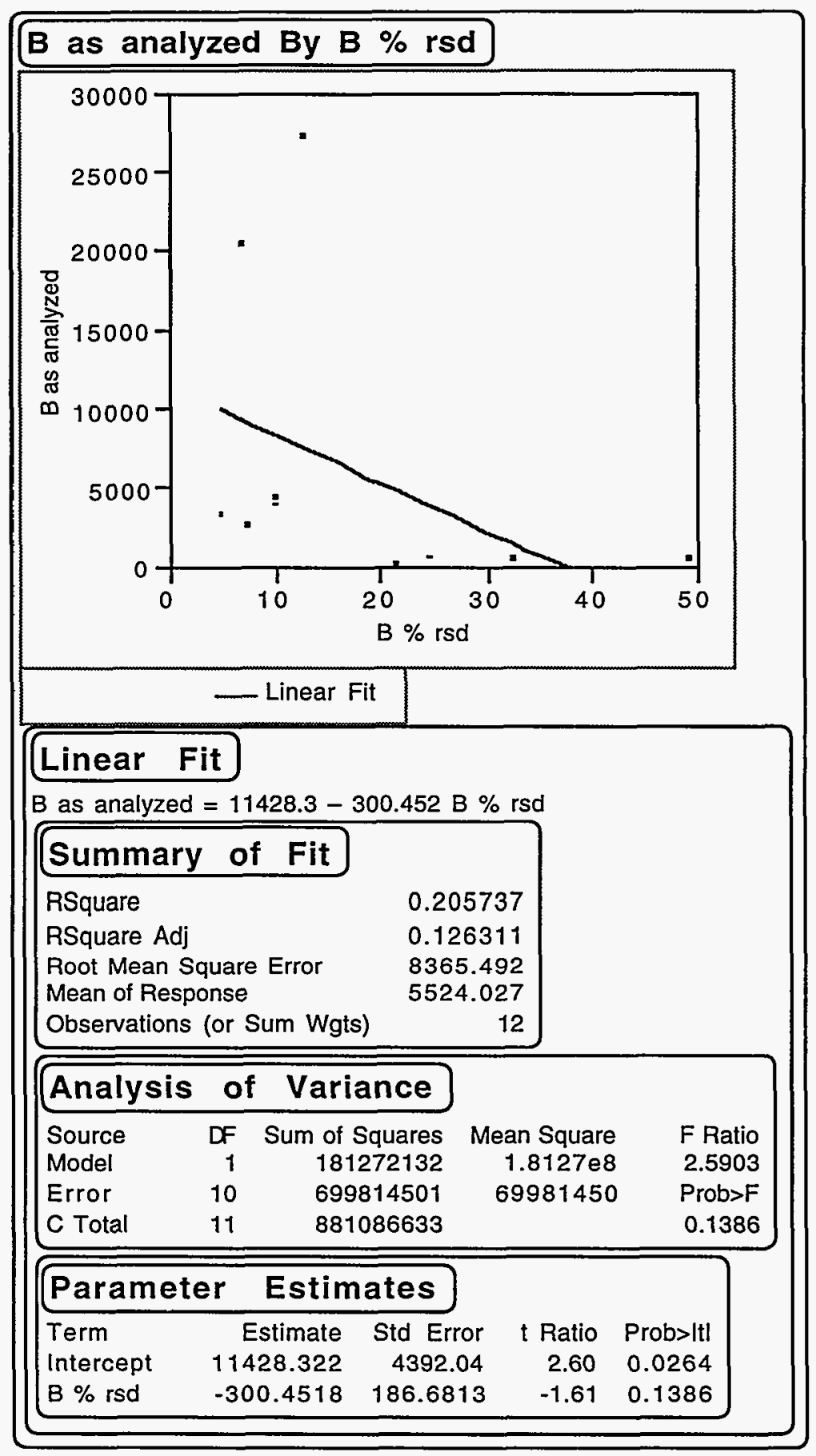

Figure 6. Linear Regression of the As-Analyzed" B Concentration vs. \% rsd of the Nine Replicates Performed for each of the 12 PATs 


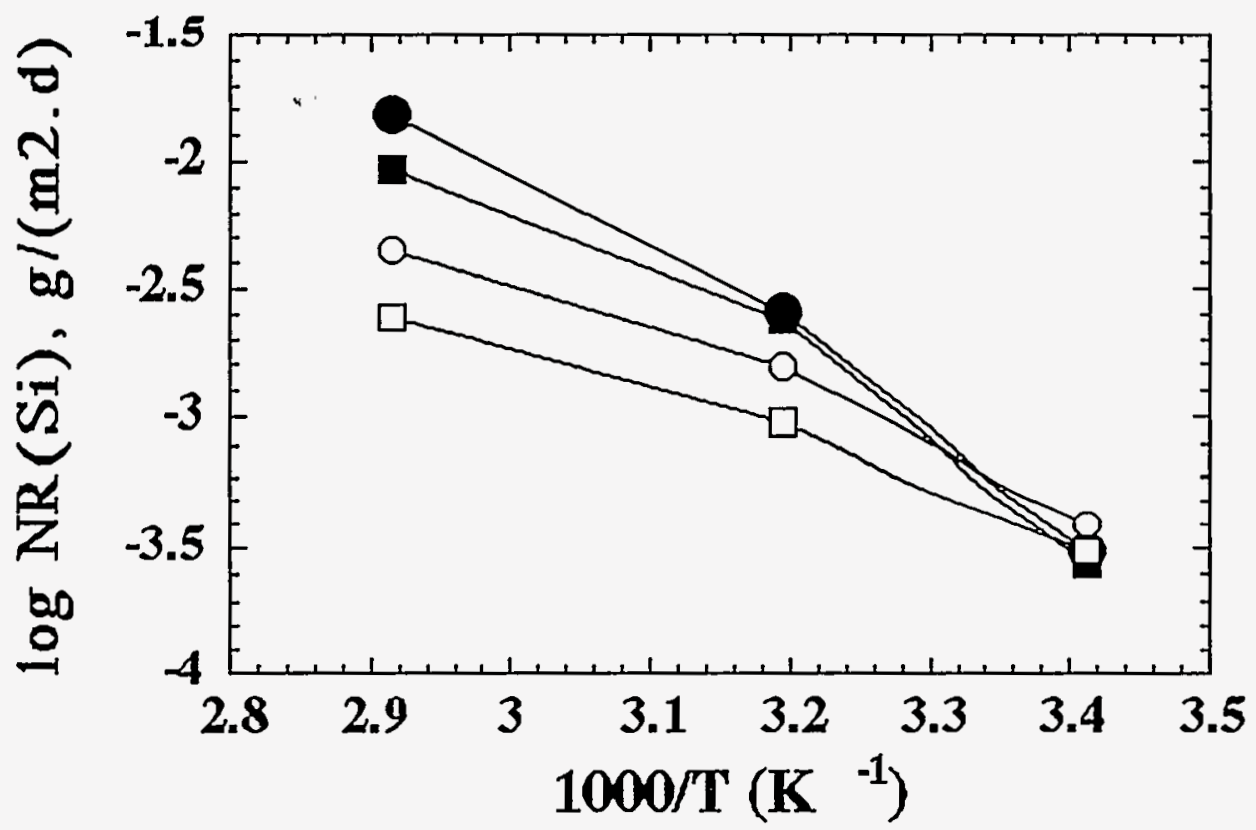

Figure 7. Arrhenius Plot Based on NR(Si) for Tests Conducted with Glass/Water Mass Ratio of 1:10 for 3 Days $(\bullet)$ or 7 days ( $(\mathbf{})$, and with Glass/Water Mass Ratio of 1:1 for 3 Days (o) and 7 Days (a) 


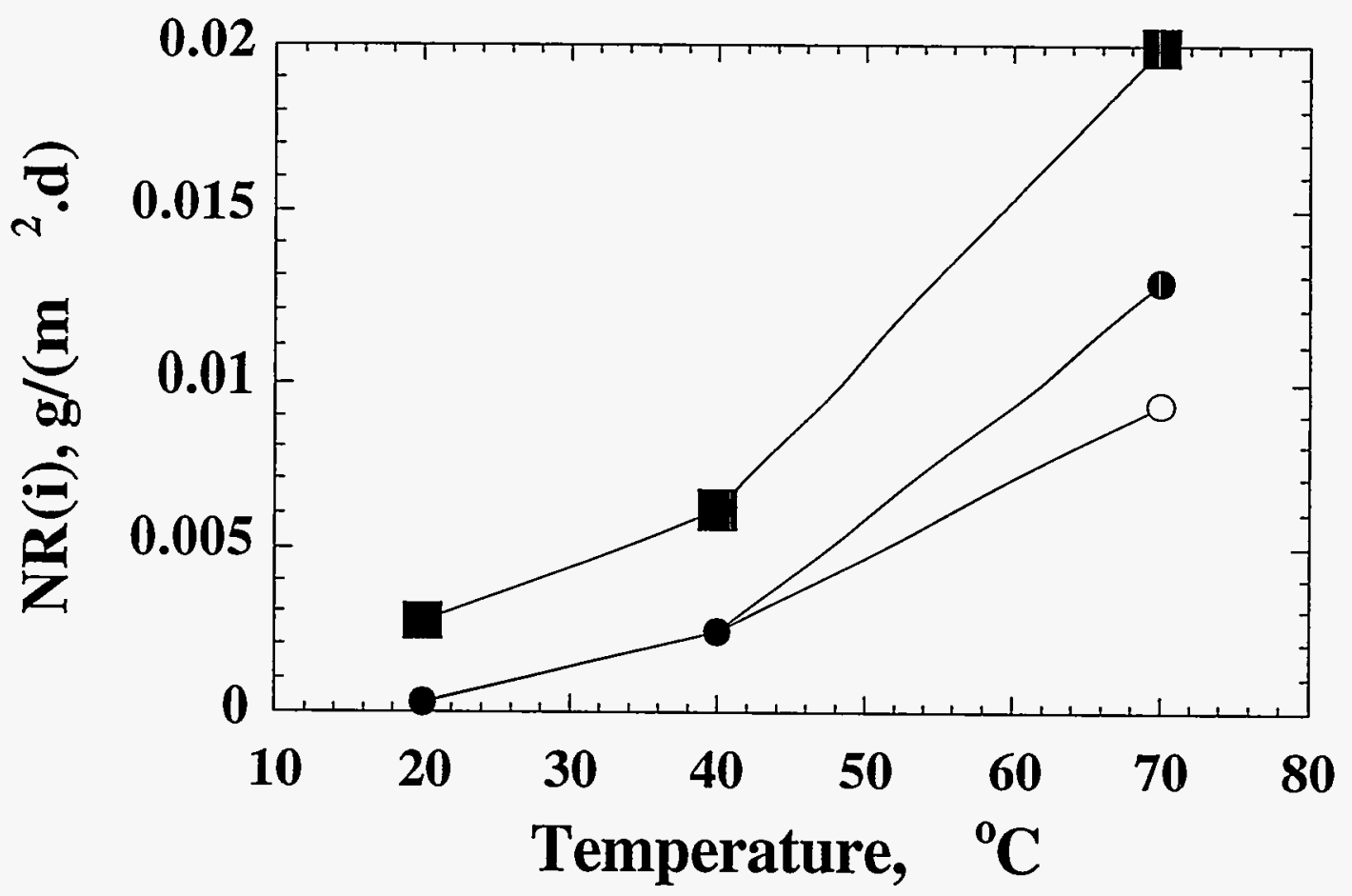

Figure 8. Temperature vs. NR(i) for Tests Conducted for Seven Days with Glass/Water Mass Ratio of $1: 10$. Release rates are for $\mathrm{i}=\mathrm{B}(\bullet), \mathrm{Na}(\boldsymbol{\bullet})$, and $\mathrm{Si}(\mathrm{o})$. Release rates are essentially identical for $\mathrm{B}$ and $\mathrm{Si}$ at 20 and $40^{\circ} \mathrm{C}$. 


\section{TABLES}

Table1. Formulated Composition of LRM Glass on an Oxide Mass \% Basis

\begin{tabular}{|c|c|c|}
\hline Component & $\begin{array}{l}\text { Formulated, } \\
\text { mass } \%\end{array}$ & Comments \\
\hline $\mathrm{Al}_{2} \mathrm{O}_{3}$ & 10 & about half from waste and half added chemical, benefits short-term durability \\
\hline $\mathrm{B}_{2} \mathrm{O}_{3}$ & 8 & added chemical, high content facilitates melting \\
\hline $\mathrm{BaO}$ & 0.005 & added as RCRA-regulated component \\
\hline $\mathrm{CaO}$ & 0.5 & $\begin{array}{l}\text { higher than anticipated from waste, may be used as additive for some ILAW } \\
\text { products }\end{array}$ \\
\hline $\mathrm{CdO}$ & 0.2 & added as RCRA-regulated component \\
\hline $\mathrm{Cl}$ & 0.8 & $\begin{array}{l}\text { twice the anticipated level for desired waste loading, expect } 50 \% \text { loss to } \\
\text { volatilization }\end{array}$ \\
\hline $\mathrm{Cr}_{2} \mathrm{O}_{3}$ & 0.2 & near solubility limit in borosilicate glasses, RCRA-regulated component \\
\hline & 1 & $\begin{array}{l}\text { twice the anticipated for desired waste loading, expect significant loss to } \\
\text { volatilization near solubility limit in borosilicate glasses }\end{array}$ \\
\hline $\mathrm{Fe}_{2} \mathrm{O}_{3}$ & 1 & $\begin{array}{l}\text { only trace amounts expected in waste stream, may be additive in pretreatment } \\
\text { or ILAW products }\end{array}$ \\
\hline $\mathrm{HgO}$ & 0.002 & $\begin{array}{l}\text { expected to be mostly volatilized during vitrification, RCRA-regulated } \\
\text { component }\end{array}$ \\
\hline I & 0.002 & expected to be partially volatilized during vitrification \\
\hline $\mathrm{K}_{2} \mathrm{O}$ & 1.5 & anticipated for desired waste loading \\
\hline $\mathrm{La}_{2} \mathrm{O}_{3}$ & 0.009 & added for use as composition standard \\
\hline $\mathrm{Li}_{2} \mathrm{O}$ & 0.1 & $\begin{array}{l}\text { added for use as composition standard, may be additive for some ILAW } \\
\text { products }\end{array}$ \\
\hline $\mathrm{MgO}$ & 0.1 & $\begin{array}{l}\text { higher than expected in waste forms to facilitate analysismay be additive for } \\
\text { some ILAW products }\end{array}$ \\
\hline $\mathrm{MnO}$ & 0.1 & added for use as composition standard \\
\hline $\mathrm{MoO}_{3}$ & 0.1 & added for use as composition standard \\
\hline $\mathrm{Na}_{2} \mathrm{O}$ & 20 & target for desired waste loading \\
\hline $\mathrm{NiO}$ & 0.1 & added for use as composition standard \\
\hline $\mathrm{P}_{2} \mathrm{O}_{5}$ & 0.5 & near solubility limit in borosilicate glasses \\
\hline $\mathrm{PbO}_{2}$ & 0.1 & added as RCRA-regulated component \\
\hline $\mathrm{SO}_{3}$ & 0.2 & $\begin{array}{l}\text { target for desired waste loading, expected to be partially volatilized during } \\
\text { vitrification }\end{array}$ \\
\hline $\mathrm{SiO}_{2}$ & 54.37 & added glass-forming chemical at a concentration typical for waste glasses \\
\hline $\mathrm{TiO}_{2}$ & 0.1 & potential additive for some ILAW products \\
\hline $\mathrm{ZrO}_{2}$ & 1 & potential additive for some ILAW products \\
\hline
\end{tabular}


Table 2. Formulation of LRM-1

\begin{tabular}{lc}
\hline \multicolumn{1}{c}{ Compound } & Mass [g] \\
\hline $\mathrm{Al}_{2} \mathrm{O}_{3}$ & 250.07 \\
$\mathrm{~B}_{2} \mathrm{O}_{3}$ & 200.03 \\
$\mathrm{BaO}$ & 0.14 \\
$\mathrm{CaO}$ & 12.50 \\
$\mathrm{CdO}$ & 5.03 \\
$\mathrm{NaCl}$ & 33.01 \\
$\mathrm{Cr}_{2} \mathrm{O}_{3}$ & 5.01 \\
$\mathrm{NaF}_{\mathrm{Fe}}$ & 55.26 \\
$\mathrm{HgO}_{3}$ & 25.04 \\
$\mathrm{KIO}_{3}$ & 0.05 \\
$\mathrm{~K}_{2} \mathrm{CO}_{3}$ & 0.10 \\
$\mathrm{La}_{2} \mathrm{O}_{3}$ & 54.98 \\
$\mathrm{Li}_{2} \mathrm{CO}_{3}$ & 0.30 \\
$\mathrm{MgO}$ & 6.19 \\
$\mathrm{MnO}_{\mathrm{MoO}_{3}}$ & 2.50 \\
$\mathrm{Na}_{2} \mathrm{CO}_{3}$ & 2.50 \\
$\mathrm{NiO}_{\mathrm{P}_{2} \mathrm{O}_{5}}$ & 2.52 \\
$\mathrm{PbO}_{\mathrm{Na}_{2} \mathrm{SO}_{4}}$ & 248.88 \\
$\mathrm{SiO}_{2}$ & 2.50 \\
$\mathrm{SnO}_{2}$ & 12.54 \\
$\mathrm{TiO}_{2}$ & 2.52 \\
$\mathrm{ZrO}_{2}$ & 8.87 \\
& 1359.26 \\
& 2.49 \\
& 2.50 \\
& 25.11 \\
& \\
& \\
& \\
&
\end{tabular}


Table 3. Test Matrix for Replicate Tests on LRM-1

\begin{tabular}{lccccc}
\hline Designation $^{2}$ & $\begin{array}{c}\text { Duration } \\
\text { [d] }\end{array}$ & $\begin{array}{c}\text { Glass/Water } \\
\text { mass ratio }\end{array}$ & $\begin{array}{c}\text { Temperature } \\
{\left[{ }^{\circ} \mathrm{C}\right]}\end{array}$ & Replicates & $\begin{array}{c}\text { Sample } \\
\text { type }\end{array}$ \\
\hline P-A-T-n & 3 & $1: 10$ & 20 & 9 & glass \\
P-A-B-n & 3 & & 20 & 3 & blank \\
P-B-T-n & 3 & $1: 10$ & 40 & 9 & glass \\
P-B-B-n & 3 & & 40 & 3 & blank \\
P-C-T-n & 3 & $1: 10$ & 70 & 9 & glass \\
P-C-B-n & 3 & & 70 & 3 & blank \\
P-D-T-n & 3 & $1: 1$ & 20 & 9 & glass \\
P-D-B-n & 3 & & 20 & 3 & blank \\
P-E-T-n & 3 & $1: 1$ & 40 & 9 & glass \\
P-E-B-n & 3 & & 40 & 3 & blank \\
P-F-T-n & 3 & $1: 1$ & 70 & 9 & glass \\
P-F-B-n & 3 & & 70 & 3 & blank \\
P-G-T-n & 7 & $1: 10$ & 20 & 9 & glass \\
P-G-B-n & 7 & & 20 & 3 & blank \\
P-H-T-n & 7 & $1: 10$ & 40 & 9 & glass \\
P-H-B-n & 7 & & 40 & 3 & blank \\
P-I-T-n & 7 & $1: 10$ & 70 & 9 & glass \\
P-I-B-n & 7 & & 70 & 3 & blank \\
P-J-T-n & 7 & $1: 1$ & 20 & 9 & glass \\
P-J-B-n & 7 & & 20 & 3 & blank \\
P-K-T-n & 7 & $1: 1$ & 40 & 9 & glass \\
P-K-B-n & 7 & & 40 & 3 & blank \\
P-L-T-n & 7 & $1: 1$ & 70 & 9 & glass \\
P-L-B-n & 7 & & 70 & 3 & blank \\
\hline P & 3 & & & \\
n-1, 2, & & & & & \\
\hline
\end{tabular}

${ }^{\mathrm{a}} \mathrm{n}=1,2, \ldots 9$ for tests with glass and $n=1,2,3$ for test blanks. 
Table 4. Test Matrix for VHT, ANSI/ANS 16.1, and TCLPs on LRM-1

\begin{tabular}{lcc}
\hline Sample Designation & Temperature $\left[{ }^{\circ} \mathrm{C}\right]$ & Duration \\
\hline & & \\
Vapor Hydration Tests & & \\
VHT-1 & $150 \pm 2$ & $7 \mathrm{~d}$ \\
VHT-2 & $150 \pm 2$ & $28 \mathrm{~d}$ \\
VHT-3 & $150 \pm 2$ & $56 \mathrm{~d}$ \\
& & \\
ANSI/ANS 16.1 Tests & $22.5 \pm 5$ & $\mathrm{a}$ \\
ANS-1-n & $22.5 \pm 5$ & $\mathrm{a}$ \\
ANS-2-n & $22.5 \pm 5$ & $\mathrm{a}$ \\
ANS-3-n & $22.5 \pm 5$ & $\mathrm{a}$ \\
ANS-Blank-n & & \\
TCLP Tests & $22 \pm 3$ & $18 \pm 2 \mathrm{~h}$ \\
TCLP-1 & $22 \pm 3$ & $18 \pm 2 \mathrm{~h}$ \\
TCLP-2 & $22 \pm 3$ & $18 \pm 2 \mathrm{~h}$ \\
TCLP-3 & $22 \pm 3$ & $18 \pm 2 \mathrm{~h}$ \\
TCLP-Blank & & \\
\hline
\end{tabular}

aSolution replaced and analyzed after cumulative leach times of $2 \mathrm{~h}, 7 \mathrm{~h}, 24 \mathrm{~h}, 2$ d, $3 \mathrm{~d}, 4 \mathrm{~d}, 5 \mathrm{~d}, 19 \pm 1 \mathrm{~d}, 47 \pm 1 \mathrm{~d}$, and $90 \pm 1 \mathrm{~d}$. The value of $n(n=1-10)$ in the sample designation indicates the solution sample number, where $n=1$ for the $2 \mathrm{~h}$ sample, $\mathrm{n}=2$ for the $7 \mathrm{~h}$ sample, etc. 
Table 5. Composition of LRM-1 as Determined with ICP-MS, ICP-AES, and IC

\begin{tabular}{|c|c|c|c|c|}
\hline Component & $\begin{array}{c}\text { Average } \\
\text { Measured } \\
\text { [wt. \%] }\end{array}$ & $\begin{array}{c}\mathbf{S} \\
{[w t \%]}\end{array}$ & $\begin{array}{c}\text { Formulated } \\
{[w t \%]}\end{array}$ & $\begin{array}{c}\text { Analytical } \\
\text { Technique(s) }\end{array}$ \\
\hline $\mathrm{Al}_{2} \mathrm{O}_{3}$ & 9.6 & 0.6 & 10 & ICP-AES, ICP-MS \\
\hline $\mathrm{B}_{2} \mathrm{O}_{3}$ & 8.1 & 0.3 & 8 & ICP-AES, ICP-MS \\
\hline $\mathrm{BaO}$ & 0.0084 & 0.0002 & 0.005 & ICP-AES, ICP-MS \\
\hline $\mathrm{CaO}$ & 0.51 & 0.06 & 0.5 & ICP-AES \\
\hline $\mathrm{CdO}$ & 0.17 & 0.01 & 0.2 & ICP-AES, ICP-MS \\
\hline $\mathrm{Cl}$ & 1.1 & - & 0.8 & IC \\
\hline $\mathrm{Cr}_{2} \mathrm{O}_{3}$ & 0.18 & 0.06 & 0.2 & ICP-AES, ICP-MS \\
\hline $\mathrm{F}$ & 0.85 & - & 1 & IC \\
\hline $\mathrm{Fe}_{2} \mathrm{O}_{3}$ & 1.0 & 0.09 & 1 & ICP-AES, ICP-MS \\
\hline $\mathrm{HgO}$ & 0.00019 & 0.0001 & 0.002 & ICP-MS \\
\hline I & 0.0025 & 0.0003 & 0.002 & ICP-MS \\
\hline $\mathrm{K}_{2} \mathrm{O}$ & 1.2 & 0.3 & 1.5 & ICP-AES, ICP-MS \\
\hline $\mathrm{La}_{2} \mathrm{O}_{3}$ & 0.0084 & 0.0001 & 0.009 & ICP-AES, ICP-MS \\
\hline $\mathrm{Li}_{2} \mathrm{O}$ & 0.081 & 0.03 & 0.1 & ICP-AES, ICP-MS \\
\hline $\mathrm{MgO}$ & 0.086 & 0.03 & 0.1 & ICP-AES, ICP-MS \\
\hline $\mathrm{MnO}$ & 0.091 & 0.02 & 0.1 & ICP-AES, ICP-MS \\
\hline $\mathrm{MoO}_{3}$ & 0.10 & 0.02 & 0.1 & ICP-AES, ICP-MS \\
\hline $\mathrm{Na}_{2} \mathrm{O}$ & 17.2 & 0.6 & 20 & ICP-AES, ICP-MS \\
\hline $\mathrm{NiO}$ & 0.082 & 0.02 & 0.1 & ICP-AES, ICP-MS \\
\hline $\mathrm{P}_{2} \mathrm{O}_{5}$ & 0.47 & 0.03 & 0.5 & ICP-AES \\
\hline $\mathrm{PbO}$ & 0.11 & 0.02 & 0.1 & ICP-AES, ICP-MS \\
\hline $\mathrm{SO}_{3}$ & 0.20 & - & 0.2 & IC \\
\hline $\mathrm{SiO}_{2}$ & 53.5 & 1 & 54.37 & ICP-MS \\
\hline $\mathrm{SnO}_{2}$ & 0.10 & 0.01 & 0.1 & ICP-AES, ICP-MS \\
\hline $\mathrm{TiO}_{2}$ & 0.10 & 0.01 & 0.1 & ICP-AES, ICP-MS \\
\hline $\mathrm{ZrO}_{2}$ & 0.91 & 0.3 & 1 & ICP-AES, ICP-MS \\
\hline Total & 95.8 & & 100. & \\
\hline
\end{tabular}

${ }^{2}$ Results of individual analyses are given in Appendix A. 
Table 6. Results of Replicate Glass Mass Density Measurements of SRM 1826a, SRM 1827a, and LRM-1

\begin{tabular}{llll}
\hline $\begin{array}{l}\text { Measurement } \\
\text { Sequence }\end{array}$ & Glass Designation & Temperature $\left[{ }^{\circ} \mathrm{C}\right]$ & Density $\left[\mathrm{g} / \mathrm{cm}^{3}\right]$ \\
\hline 1 & SRM 1826a & 22.25 & \\
2 & SRM 1827a & 22.25 & 2.5500 \\
3 & SRM 1826a & 22.25 & 3.5951 \\
4 & SRM 1827a & 22.25 & 2.5487 \\
5 & SRM 1826a & 22.26 & 3.5934 \\
6 & SRM 1827a & 22.26 & 2.5486 \\
& & & 3.5856 \\
7 & LRM-1 D1 & 22.27 & \\
8 & LRM-1 D2 & 22.27 & 2.5052 \\
9 & LRM-1 D3 & 22.28 & 2.5102 \\
10 & LRM-1 D4 & 22.28 & 2.5061 \\
11 & LRM-1 D5 & 22.29 & 2.5104 \\
12 & LRM-1 D6 & 22.29 & 2.5207 \\
13 & LRM-1 D7 & 22.29 & 2.5222 \\
14 & LRM-1 D8 & 22.29 & 2.5282 \\
15 & SRM 1826a & 22.30 & 2.5494 \\
16 & SRM 1827a & 22.30 & 3.5940 \\
& & & mean $\pm \mathrm{s}$ \\
\hline & & & $2.549 \pm 0.001$ \\
& 1826a & & $3.592 \pm 0.004$ \\
& 1827a & & $2.516 \pm 0.009$ \\
& LRM-1 & & \\
& & & \\
\hline
\end{tabular}


Table 7. Results from Compressive Strength Tests on LRM-1

\begin{tabular}{|c|c|c|c|c|c|c|c|}
\hline $\begin{array}{l}\text { Sample } \\
\text { Designation }\end{array}$ & $\begin{array}{l}\text { Diameter } \\
\text { (in) }\end{array}$ & $\begin{array}{c}\text { Mean } \\
\text { Diameter } \\
\text { (in) }\end{array}$ & $\begin{array}{l}\text { Length } \\
\text { (in) }\end{array}$ & $\begin{array}{l}\text { Mean } \\
\text { Length } \\
\text { (in) }\end{array}$ & $\begin{array}{c}\text { Cross- } \\
\text { Sectional } \\
\text { Area }\left(\text { in }^{2}\right) \\
\end{array}$ & $\begin{array}{l}\text { Peak } \\
\text { Load } \\
\text { (lb.) }\end{array}$ & $\begin{array}{c}\text { Strength } \\
\text { (psi) }\end{array}$ \\
\hline CS-1 & $\begin{array}{l}0.3844 \\
0.3832 \\
0.3838\end{array}$ & 0.3838 & $\begin{array}{l}0.7915 \\
0.7872 \\
0.7929\end{array}$ & 0.7905 & 0.1157 & 3238 & 27,988 \\
\hline CS-2 & $\begin{array}{l}0.3820 \\
0.3840 \\
0.3849\end{array}$ & 0.3833 & $\begin{array}{l}0.7821 \\
0.7822 \\
0.7778\end{array}$ & 0.7807 & 0.1154 & 3817 & 33,179 \\
\hline $\mathrm{CS}-3$ & $\begin{array}{l}0.3844 \\
0.3844 \\
0.3852\end{array}$ & 0.3847 & $\begin{array}{l}0.7875 \\
0.7876 \\
0.7889\end{array}$ & 0.7880 & 0.1162 & 5351 & 46,036 \\
\hline \multirow[t]{2}{*}{$\mathrm{CS}-4$} & $\begin{array}{l}0.3828 \\
0.3806 \\
0.3824\end{array}$ & 0.3819 & $\begin{array}{l}0.7889 \\
0.7895 \\
0.7890\end{array}$ & 0.7891 & 0.1145 & 2773 & 24,208 \\
\hline & & & & & & ${ }_{\mathrm{s}}^{\text {mean }}$ & $\begin{array}{c}32,828 \\
9,526\end{array}$ \\
\hline
\end{tabular}


Table 8. Concentrations $[\mu \mathrm{g} / \mathrm{L}]$ of $\mathrm{Na}, \mathrm{Si}, \mathrm{B}, \mathrm{Al}$, and $\mathrm{K}$ in Water Used in Tests

\begin{tabular}{llllll}
\hline Date & $\mathrm{Na}$ & $\mathrm{Si}$ & $\mathrm{B}$ & $\mathrm{Al}$ & $\mathrm{K}$ \\
\hline $8 / 11 / 97$ & 14.3 & $<60$ & $<0.8$ & $<2$ & $<100$ \\
$8 / 26 / 97$ & 25.8 & $<30$ & $<7$ & $<7$ & $<50$ \\
$9 / 8 / 97$ & $<100$ & $<40$ & $<6$ & $<3$ & $<200$ \\
\hline
\end{tabular}


Table 9. Final pHs and Concentrations of $\mathrm{Na}, \mathrm{Si}, \mathrm{B}, \mathrm{Al}$, and $\mathrm{K}$ in Leachates from 3-, and 7-Day Test Blanks. Means, sample standard deviations, and relative standard deviations are calculated from the pooled results for quantifiable elements.

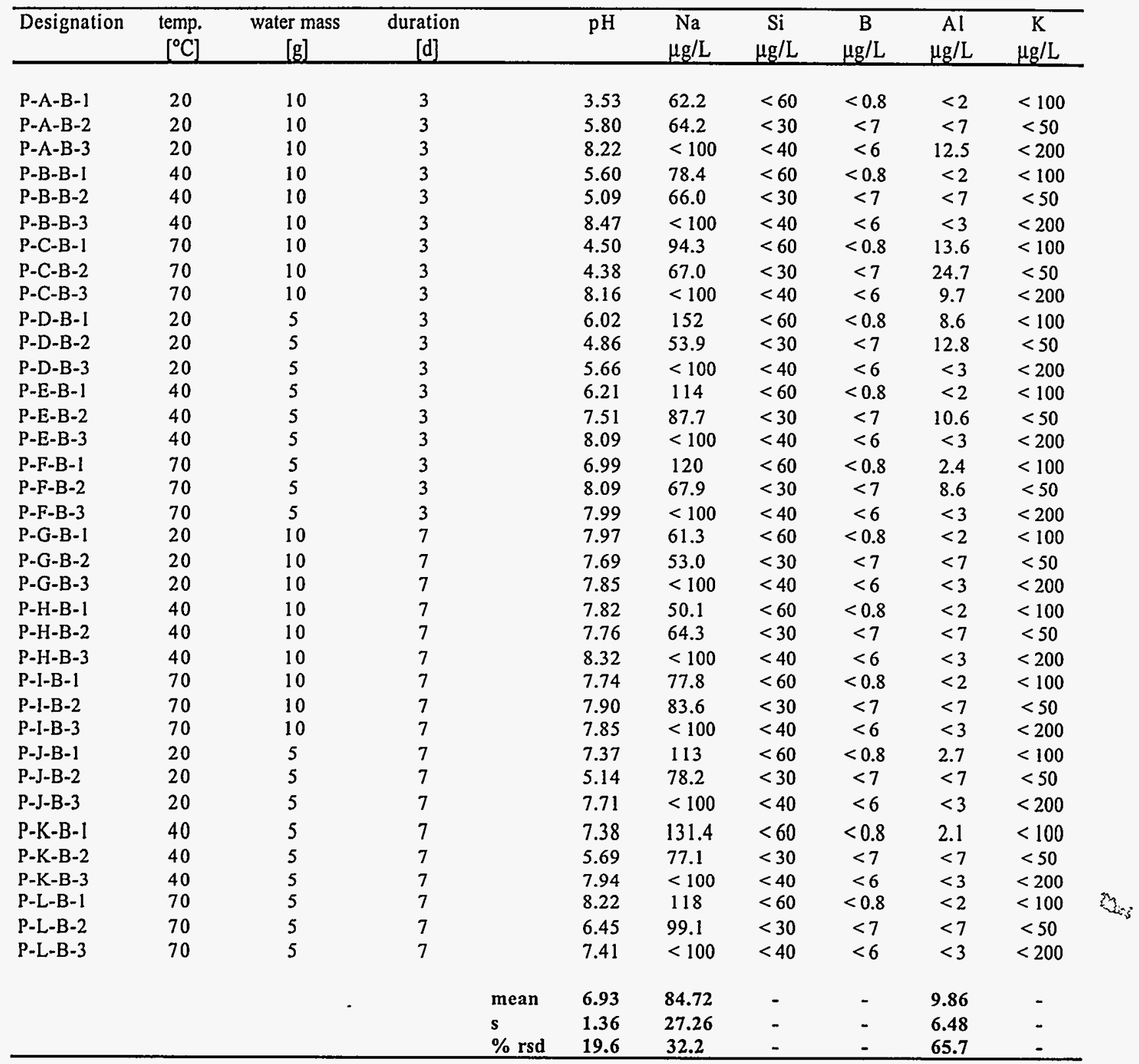


Table 10a. Final pHs and Concentrations of $\mathrm{Na}, \mathrm{Si}, \mathrm{B}, \mathrm{Al}$, and $\mathrm{K}$ in Leachates from 3-Day, 1:10 Tests $^{\mathrm{a}}$

\begin{tabular}{|c|c|c|c|c|c|c|c|c|c|c|}
\hline Designation & $\begin{array}{l}\text { temp. } \\
{\left[{ }^{\circ} \mathrm{C}\right]}\end{array}$ & $\begin{array}{c}\text { glass/water } \\
{[\mathrm{g} / \mathrm{g}]}\end{array}$ & $\begin{array}{c}\text { duration } \\
\text { [d] }\end{array}$ & & $\mathrm{pH}$ & $\begin{array}{c}\mathrm{Na} \\
\mathrm{mg} / \mathrm{L}\end{array}$ & $\begin{array}{c}\mathrm{Si} \\
\mathrm{mg} / \mathrm{L}\end{array}$ & $\begin{array}{c}\mathrm{B} \\
\mathrm{mg} / \mathrm{L}\end{array}$ & $\begin{array}{c}\mathrm{Al} \\
\mathrm{mg} / \mathrm{L}\end{array}$ & $\begin{array}{c}\mathrm{K} \\
\mathrm{mg} / \mathrm{L}\end{array}$ \\
\hline P-A-T-1 & 20 & $1: 10$ & 3 & & 8.91 & 5.25 & 0.64 & 0.07 & 0.12 & $<0.09$ \\
\hline P-A-T-2 & 20 & $1: 10$ & 3 & & 8.92 & 5.03 & 0.43 & 0.07 & 0.12 & $<0.09$ \\
\hline P-A-T-3 & 20 & $1: 10$ & 3 & & 8.95 & 4.84 & 0.57 & 0.06 & 0.13 & $<0.09$ \\
\hline P-A-T-4 & 20 & $1: 10$ & 3 & & 9.18 & 4.98 & 0.51 & 0.08 & 0.08 & $<0.1$ \\
\hline P-A-T-5 & 20 & $1: 10$ & 3 & & 9.09 & 5.40 & 0.49 & 0.09 & 0.08 & $<0.1$ \\
\hline P-A-T-6 & 20 & $1: 10$ & 3 & & 9.11 & 5.51 & 0.45 & 0.09 & 0.09 & $<0.1$ \\
\hline P-A-T-7 & 20 & $1: 10$ & 3 & & 9.12 & 5.34 & 0.46 & 0.12 & 0.10 & $<0.09$ \\
\hline P-A-T-8 & 20 & $1: 10$ & 3 & & 9.02 & 5.30 & 0.48 & 0.12 & 0.12 & $<0.09$ \\
\hline \multirow[t]{4}{*}{ P-A-T-9 } & 20 & $1: 10$ & 3 & & 9.23 & 5.31 & 0.52 & 0.13 & 0.14 & $<0.09$ \\
\hline & & & & mean & 9.06 & 5.22 & 0.50 & 0.09 & 0.11 & - \\
\hline & & & & & 0.12 & 0.22 & 0.06 & 0.03 & 0.02 & - \\
\hline & & & & $\%$ rsd & 1.27 & 4.18 & 12.53 & 28.33 & 18.39 & - \\
\hline P-B-T-1 & 40 & $1: 10$ & 3 & & 9.35 & 11.1 & 5.09 & 0.38 & 1.22 & 0.23 \\
\hline P-B-T-2 & 40 & $1: 10$ & 3 & & $9.3 \mathrm{I}$ & 10.7 & 4.54 & 0.36 & 1.14 & 0.16 \\
\hline P-B-T-3 & 40 & $1: 10$ & 3 & & 9.36 & 10.8 & 4.72 & 0.38 & 1.09 & 0.22 \\
\hline P-B-T-4 & 40 & $1: 10$ & 3 & & 9.33 & 11.2 & 3.82 & 0.35 & 0.68 & $<0.1$ \\
\hline P-B-T-5 & 40 & $1: 10$ & 3 & & 9.38 & 11.3 & 3.76 & 0.36 & 0.76 & $<0.1$ \\
\hline P-B-T-6 & 40 & $1: 10$ & 3 & & 9.42 & 10.8 & 3.65 & 0.34 & 0.78 & $<0.1$ \\
\hline P-B-T-7 & 40 & $1: 10$ & 3 & & 9.31 & 10.0 & 3.88 & 0.55 & 0.69 & 0.12 \\
\hline P-B-T-8 & 40 & $1: 10$ & 3 & & 9.32 & 10.3 & 3.91 & 0.57 & 0.74 & $<0.09$ \\
\hline \multirow[t]{4}{*}{ P-B-T-9 } & 40 & $1: 10$ & 3 & & 9.49 & 9.2 & 3.85 & 0.48 & 0.70 & $<0.09$ \\
\hline & & & & mean & 9.36 & 10.60 & 4.14 & 0.42 & 0.87 & 0.18 \\
\hline & & & & & 0.06 & 0.67 & 0.51 & 0.09 & 0.22 & 0.05 \\
\hline & & & & $\%$ rsd & 0.63 & 6.33 & 12.37 & 21.25 & 25.00 & 29.02 \\
\hline P-C-T-1 & 70 & $1: 10$ & 3 & & 9.78 & 32.4 & 23.0 & 3.63 & 5.65 & 0.81 \\
\hline P-C-T-2 & 70 & $1: 10$ & 3 & & 9.78 & 34.4 & 23.6 & 3.50 & 5.35 & 0.77 \\
\hline P-C-T-3 & 70 & $1: 10$ & 3 & & 9.73 & 31.9 & 22.2 & 3.54 & 5.12 & 0.71 \\
\hline P-C-T-4 & 70 & $1: 10$ & 3 & & 9.62 & 32.7 & 23.3 & 3.30 & 4.71 & 0.55 \\
\hline P-C-T-5 & 70 & $1: 10$ & 3 & & 9.67 & 36.2 & 25.2 & 3.23 & 4.52 & 0.51 \\
\hline P-C-T-6 & 70 & $1: 10$ & 3 & & 9.71 & 35.8 & 25.1 & 3.33 & 4.31 & 0.55 \\
\hline P-C-T-7 & 70 & $1: 10$ & 3 & & 9.67 & 34.5 & 26.6 & 3.61 & 5.09 & 0.58 \\
\hline P-C-T-8 & 70 & $1: 10$ & 3 & & 9.60 & 33.0 & 26.9 & 3.69 & 5.34 & 0.61 \\
\hline \multirow[t]{4}{*}{ P-C-T-9 } & 70 & $1: 10$ & 3 & & 9.65 & 32.4 & 26.5 & 3.65 & 5.20 & 0.60 \\
\hline & & & & mean & 9.69 & 33.70 & 24.72 & 3.50 & 5.03 & 0.63 \\
\hline & & & & & 0.06 & 1.57 & 1.75 & 0.17 & 0.43 & 0.11 \\
\hline & & & & $\%$ rsd & 0.66 & 4.66 & 7.10 & 4.81 & 8.63 & 16.84 \\
\hline
\end{tabular}

${ }^{2}$ Means, sample standard deviations, and relative standard deviations are calculated for three sets of triplicate tests. 
Table 10b. Final pHs and Concentrations of $\mathrm{Na}, \mathrm{Si}, \mathrm{B}, \mathrm{Al}$, and $\mathrm{K}$ in Leachates from 3-Day, 1:1 Tests $^{\mathbf{a}}$

\begin{tabular}{|c|c|c|c|c|c|c|c|c|c|c|}
\hline Designation & $\begin{array}{l}\text { temp. } \\
{\left[{ }^{\circ} \mathrm{C}\right]}\end{array}$ & $\begin{array}{c}\text { glass/water } \\
{[\mathrm{g} / \mathrm{g}]}\end{array}$ & $\begin{array}{c}\text { duration } \\
\text { [d] }\end{array}$ & & $\mathrm{pH}$ & $\begin{array}{l}\mathrm{Na} \\
\mathrm{mg} / \mathrm{L}\end{array}$ & $\begin{array}{c}\mathrm{Si} \\
\mathrm{mg} / \mathrm{L}\end{array}$ & $\begin{array}{c}\mathrm{B} \\
\mathrm{mg} / \mathrm{L}\end{array}$ & $\begin{array}{c}\mathrm{Al} \\
\mathrm{mg} / \mathrm{L}\end{array}$ & $\begin{array}{c}\mathrm{K} \\
\mathrm{mg} / \mathrm{L} \\
\end{array}$ \\
\hline P-D-T-1 & 20 & $1: 1$ & 3 & & 10.21 & 34.4 & 7.43 & 0.42 & 1.25 & 0.36 \\
\hline P-D-T-2 & 20 & $1: 1$ & 3 & & 10.08 & 32.6 & 6.63 & 0.41 & 1.18 & 0.37 \\
\hline P-D-T-3 & 20 & $1: 1$ & 3 & & 10.20 & 33.2 & 6.65 & 0.45 & 1.40 & 0.47 \\
\hline P-D-T-4 & 20 & $1: 1$ & 3 & & 10.19 & 38.5 & 6.12 & 0.59 & 0.55 & 0.21 \\
\hline P-D-T-5 & 20 & $1: 1$ & 3 & & 10.16 & 36.9 & 6.22 & 0.62 & 0.64 & 0.21 \\
\hline P-D-T-6 & 20 & $1: 1$ & 3 & & 10.16 & 39.6 & 6.03 & 0.62 & 0.67 & 0.24 \\
\hline P-D-T-7 & 20 & $1: 1$ & 3 & & 10.20 & 34.6 & 6.01 & 0.97 & 0.79 & 0.25 \\
\hline P-D-T-8 & 20 & $1: 1$ & 3 & & 10.26 & 36.8 & 6.31 & 0.87 & 0.71 & 0.21 \\
\hline \multirow[t]{4}{*}{ P-D-T-9 } & 20 & $1: 1$ & 3 & & 10.22 & 35.0 & 5.79 & 0.85 & 0.67 & 0.22 \\
\hline & & & & mean & 10.19 & 35.73 & 6.35 & 0.64 & 0.87 & 0.28 \\
\hline & & & & & 0.05 & 2.37 & 0.49 & 0.21 & 0.31 & 0.10 \\
\hline & & & & $\%$ rsd & 0.48 & 6.64 & 7.73 & 32.35 & 35.89 & 33.89 \\
\hline P-E-T-1 & 40 & $1: 1$ & 3 & & 10.28 & 62.2 & 23.3 & 2.70 & 4.21 & 0.86 \\
\hline P-E-T-2 & 40 & $1: 1$ & 3 & & 10.31 & 63.7 & 25.8 & 2.78 & 4.75 & 0.91 \\
\hline P-E-T-3 & 40 & $1: 1$ & 3 & & 10.40 & 61.4 & 24.3 & 2.87 & 5.08 & 0.90 \\
\hline P-E-T-4 & 40 & $1: 1$ & 3 & & 10.30 & 60.5 & 23.8 & 3.14 & 4.02 & 0.65 \\
\hline P-E-T-5 & 40 & $1: 1$ & 3 & & 10.29 & 64.7 & 25.8 & 2.68 & 3.44 & 0.55 \\
\hline P-E-T-6 & 40 & $1: 1$ & 3 & & 10.35 & 62.6 & 25.5 & 3.06 & 3.90 & 0.55 \\
\hline P-E-T-7 & 40 & $1: 1$ & 3 & & 10.40 & 62.4 & 25.2 & 3.30 & 3.97 & 0.65 \\
\hline P-E-T-8 & 40 & $1: 1$ & 3 & & 10.45 & 65.0 & 27.0 & 3.06 & 3.86 & 0.66 \\
\hline \multirow[t]{3}{*}{ P-E-T-9 } & 40 & $1: 1$ & 3 & & 10.49 & 63.4 & 25.6 & 3.09 & 3.81 & 0.65 \\
\hline & & & & mean & 10.36 & 62.90 & 25.17 & 2.96 & 4.11 & 0.71 \\
\hline & & & & $\begin{array}{l}\text { s } \\
\% \text { rsd }\end{array}$ & $\begin{array}{l}0.07 \\
0.72\end{array}$ & $\begin{array}{l}1.48 \\
2.35\end{array}$ & $\begin{array}{l}1.15 \\
4.55\end{array}$ & $\begin{array}{l}0.22 \\
7.28\end{array}$ & $\begin{array}{c}0.50 \\
12.23\end{array}$ & $\begin{array}{c}0.14 \\
20.09\end{array}$ \\
\hline P-F-T-1 & 70 & $1: 1$ & 3 & & 10.93 & 199 & 73.9 & 20.3 & 10.3 & 3.25 \\
\hline P-F-T-2 & 70 & $1: 1$ & 3 & & 10.94 & 185 & 65.6 & 19.5 & 10.9 & 3.11 \\
\hline P-F-T-3 & 70 & $1: 1$ & 3 & & 10.91 & 196 & 67.4 & 20.0 & 10.2 & 3.20 \\
\hline P-F-T-4 & 70 & $1: 1$ & 3 & & 10.90 & 221 & 87.8 & 19.6 & 9.1 & 2.45 \\
\hline P-F-T-5 & 70 & $1: 1$ & 3 & & 10.91 & 200 & 75.7 & 23.8 & 11.6 & 4.10 \\
\hline P-F-T-6 & 70 & $1: 1$ & 3 & & 10.92 & 201 & 74.8 & 22.0 & 10.4 & 2.98 \\
\hline P-F-T-7 & 70 & $1: 1$ & 3 & & 10.92 & 184 & 79.6 & 19.9 & 9.9 & 2.92 \\
\hline P-F-T-8 & 70 & $1: 1$ & 3 & & 10.95 & 171 & 72.7 & 20.5 & 9.9 & 3.07 \\
\hline \multirow[t]{3}{*}{ P-F-T-9 } & 70 & $1: 1$ & 3 & & 10.97 & 185 & 77.3 & 20.1 & 9.6 & 2.96 \\
\hline & & & & mean & 10.93 & 193.62 & 74.98 & 20.64 & 10.21 & 3.12 \\
\hline & & - & & $\begin{array}{ll}\text { s } & \\
\% & \text { rsd } \\
\end{array}$ & $\begin{array}{l}0.02 \\
0.20 \\
\end{array}$ & $\begin{array}{l}14.35 \\
7.41 \\
\end{array}$ & $\begin{array}{l}6.56 \\
8.75 \\
\end{array}$ & $\begin{array}{l}1.40 \\
6.77 \\
\end{array}$ & $\begin{array}{l}0.73 \\
7.17 \\
\end{array}$ & $\begin{array}{c}0.43 \\
13.96 \\
\end{array}$ \\
\hline
\end{tabular}

${ }^{a}$ Means, sample standard deviations, and relative standard deviations are calculated for three sets of triplicate tests. 
Table 10c. Final pHs and Concentrations of $\mathrm{Na}, \mathrm{Si}, \mathrm{B}, \mathrm{Al}$, and $\mathrm{K}$ in Leachates from 7-Day, 1:10 Tests $^{\mathrm{a}}$

\begin{tabular}{|c|c|c|c|c|c|c|c|c|c|c|}
\hline Designation & $\begin{array}{r}\text { temp. } \\
{\left[{ }^{\circ} \mathrm{C}\right]}\end{array}$ & $\begin{array}{c}\text { glass/water } \\
{[\mathrm{g} / \mathrm{g}]}\end{array}$ & $\begin{array}{c}\text { duration } \\
\text { [d] }\end{array}$ & & $\mathrm{pH}$ & $\begin{array}{l}\mathrm{Na} \\
\mathrm{mg} / \mathrm{L}\end{array}$ & $\begin{array}{c}\mathrm{Si} \\
\mathrm{mg} / \mathrm{L}\end{array}$ & $\begin{array}{c}\mathrm{B} \\
\mathrm{mg} / \mathrm{L} \\
\end{array}$ & $\begin{array}{c}\mathrm{Al} \\
\mathrm{mg} / \mathrm{L}\end{array}$ & $\begin{array}{c}\mathrm{K} \\
\mathrm{mg} / \mathrm{L}\end{array}$ \\
\hline P-G-T-1 & 20 & $1: 10$ & 7 & & 9.45 & 5.39 & 1.28 & 0.09 & 0.33 & $<0.1$ \\
\hline $\begin{array}{l}P-G-T-2 \\
P-G-T-3\end{array}$ & $\begin{array}{l}20 \\
20\end{array}$ & $\begin{array}{l}1: 10 \\
1: 10\end{array}$ & $\begin{array}{l}7 \\
7\end{array}$ & & $\begin{array}{l}9.34 \\
9.44\end{array}$ & $\begin{array}{l}5.49 \\
5.71\end{array}$ & $\begin{array}{l}1.27 \\
1.28\end{array}$ & $\begin{array}{l}0.09 \\
0.10\end{array}$ & $\begin{array}{l}0.33 \\
0.32\end{array}$ & $\begin{array}{l}<0.1 \\
<0.1\end{array}$ \\
\hline P-G-T-4 & 20 & $1: 10$ & 7 & & 8.93 & 6.28 & 0.91 & 0.09 & 0.15 & $<0.05$ \\
\hline $\mathrm{P}-\mathrm{G}-\mathrm{T}-\mathrm{S}$ & 20 & $1: 10$ & 7 & & 8.90 & 6.11 & 0.88 & 0.09 & 0.15 & $<0.05$ \\
\hline $\begin{array}{l}\text { P-G-T-6 } \\
\text { P-G-T-7 }\end{array}$ & $\begin{array}{l}20 \\
20\end{array}$ & $\begin{array}{l}1: 10 \\
1: 10\end{array}$ & $\begin{array}{l}7 \\
7\end{array}$ & & $\begin{array}{l}9.13 \\
8.89\end{array}$ & $\begin{array}{l}6.28 \\
6.14\end{array}$ & $\begin{array}{l}1.00 \\
0.86\end{array}$ & $\begin{array}{l}0.09 \\
0.15\end{array}$ & $\begin{array}{l}0.15 \\
0.16\end{array}$ & $\begin{array}{l}<0.05 \\
<0.07\end{array}$ \\
\hline P-G-T-8 & 20 & $1: 10$ & 7 & & 8.96 & 5.92 & 0.86 & 0.16 & 0.14 & $<0.07$ \\
\hline \multirow[t]{3}{*}{ P-G-T-9 } & 20 & $1: 10$ & 7 & & 9.15 & 5.54 & 0.94 & 0.16 & 0.17 & $<0.07$ \\
\hline & & & & mean & 9.13 & 5.87 & 1.03 & 0.11 & 0.21 & - \\
\hline & & & & $\begin{array}{l}\text { s } \\
\% \text { rsd }\end{array}$ & $\begin{array}{l}0.23 \\
2.52\end{array}$ & $\begin{array}{l}0.35 \\
5.93\end{array}$ & $\begin{array}{c}0.19 \\
18.37\end{array}$ & $\begin{array}{c}0.03 \\
29.43\end{array}$ & $\begin{array}{c}0.09 \\
41.67\end{array}$ & - \\
\hline P-H-T-1 & 40 & $1: 10$ & 7 & & 9.50 & 13.6 & 10.1 & 1.03 & 2.16 & $<0.1$ \\
\hline P-H-T-2 & 40 & $1: 10$ & 7 & & 9.49 & 14.4 & 10.4 & 0.99 & 2.23 & $<0.1$ \\
\hline P-H-T-3 & 40 & $1: 10$ & 7 & & 9.47 & 13.2 & 9.22 & 1.00 & 2.13 & $<0.1$ \\
\hline $\begin{array}{l}\text { P-H-T-4 } \\
\text { P-H-T-5 }\end{array}$ & $\begin{array}{l}40 \\
40\end{array}$ & $\begin{array}{l}1: 10 \\
1: 10\end{array}$ & $\begin{array}{l}7 \\
7\end{array}$ & & $\begin{array}{l}9.31 \\
9.33\end{array}$ & $\begin{array}{l}14.1 \\
14.2\end{array}$ & $\begin{array}{l}8.29 \\
9.17\end{array}$ & $\begin{array}{l}0.75 \\
0.77\end{array}$ & $\begin{array}{l}1.40 \\
1.36\end{array}$ & $\begin{array}{l}0.07 \\
0.09\end{array}$ \\
\hline P-H-T-6 & 40 & $1: 10$ & 7 & & 9.42 & 13.8 & 8.60 & 0.78 & 1.21 & 0.07 \\
\hline P-H-T-7 & 40 & $1: 10$ & 7 & & 9.59 & 12.8 & 8.76 & 0.98 & 1.56 & 0.15 \\
\hline P-H-T-8 & 40 & $1: 10$ & 7 & & 9.30 & 11.7 & 7.47 & 1.01 & 1.53 & 0.15 \\
\hline \multirow[t]{3}{*}{ P-H-T-9 } & 40 & $1: 10$ & 7 & & 9.31 & 12.2 & 8.03 & 1.01 & 1.58 & 0.16 \\
\hline & & & & mean & 9.41 & 13.32 & 8.90 & 0.92 & 1.69 & 0.12 \\
\hline & & & & $\begin{array}{l}\text { s } \\
\% \text { rsd }\end{array}$ & $\begin{array}{l}0.10 \\
1.10\end{array}$ & $\begin{array}{l}0.93 \\
6.95\end{array}$ & $\begin{array}{c}0.95 \\
10.70\end{array}$ & $\begin{array}{c}0.12 \\
13.01\end{array}$ & $\begin{array}{c}0.38 \\
22.75\end{array}$ & $\begin{array}{c}0.04 \\
36.69\end{array}$ \\
\hline P-I-T-1 & 70 & $1: 10$ & 7 & & 9.93 & 46.9 & 38.3 & 4.97 & 7.97 & 0.90 \\
\hline P-I-T-2 & 70 & $1: 10$ & 7 & & 9.90 & 42.1 & 34.8 & 5.09 & 7.89 & 0.73 \\
\hline P-I-T-3 & 70 & $1: 10$ & 7 & & 9.95 & 43.0 & 36.2 & 4.91 & 7.85 & 0.76 \\
\hline P-I-T-4 & 70 & $1: 10$ & 7 & & 9.79 & 45.2 & 34.7 & 4.08 & 5.62 & 0.58 \\
\hline P-I-T-5 & 70 & $1: 10$ & 7 & & 9.79 & 44.9 & 34.1 & 4.05 & 5.54 & 0.57 \\
\hline P-I-T-6 & 70 & $1: 10$ & 7 & & 9.83 & 42.2 & 33.0 & 4.09 & 5.50 & 0.59 \\
\hline P-I-T-7 & 70 & $1: 10$ & 7 & & 9.81 & 41.5 & 33.1 & 5.07 & 6.89 & 0.91 \\
\hline P-I-T-8 & 70 & $1: 10$ & 7 & & 9.86 & 42.4 & 34.9 & 4.99 & 6.84 & 0.90 \\
\hline \multirow[t]{3}{*}{ P-I-T-9 } & 70 & $1: 10$ & 7 & & 9.87 & 42.8 & 34.9 & 4.79 & 6.51 & 0.85 \\
\hline & & & & mean & 9.86 & 43.45 & 34.89 & 4.67 & 6.74 & 0.75 \\
\hline & & & & $\begin{array}{l}\text { s } \\
\% \text { rsd }\end{array}$ & $\begin{array}{l}0.06 \\
0.60\end{array}$ & $\begin{array}{l}1.82 \\
4.18\end{array}$ & $\begin{array}{l}1.60 \\
4.59\end{array}$ & $\begin{array}{l}0.45 \\
9.73\end{array}$ & $\begin{array}{c}1.02 \\
15.19\end{array}$ & $\begin{array}{c}0.14 \\
19.25 \\
\end{array}$ \\
\hline
\end{tabular}

${ }^{2}$ Means, sample standard deviations, and relative standard deviations are calculated for three sets of triplicate tests. 
Table 10d. Final pHs and Concentrations of $\mathrm{Na}, \mathrm{Si}, \mathrm{B}, \mathrm{Al}$, and $\mathrm{K}$ in Leachates from 7-Day, 1:1 Tests $^{\mathrm{a}}$

\begin{tabular}{|c|c|c|c|c|c|c|c|c|c|c|}
\hline Designation & $\begin{array}{l}\text { temp. } \\
{\left[{ }^{\circ} \mathrm{C}\right]}\end{array}$ & $\begin{array}{c}\text { glass/water } \\
{[\mathrm{g} / \mathrm{g}]}\end{array}$ & $\begin{array}{c}\text { duration } \\
\text { [d] }\end{array}$ & & $\mathrm{pH}$ & $\begin{array}{c}\mathrm{Na} \\
\mathrm{mg} / \mathrm{L}\end{array}$ & $\begin{array}{c}\mathrm{Si} \\
\mathrm{mg} / \mathrm{L}\end{array}$ & $\begin{array}{c}\mathrm{B} \\
\mathrm{mg} / \mathrm{L}\end{array}$ & $\begin{array}{c}\mathrm{Al} \\
\mathrm{mg} / \mathrm{L}\end{array}$ & $\begin{array}{c}\mathrm{K} \\
\mathrm{mg} / \mathrm{L}\end{array}$ \\
\hline P-J-T-1 & 20 & $1: 1$ & 7 & & 10.38 & 39.9 & 14.4 & 0.62 & 2.50 & 0.16 \\
\hline $\begin{array}{l}\text { P-J-T-2 } \\
\text { P-J-T-3 }\end{array}$ & $\begin{array}{l}20 \\
20\end{array}$ & $\begin{array}{l}1: 1 \\
1: 1\end{array}$ & $\begin{array}{l}7 \\
7\end{array}$ & & $\begin{array}{l}10.41 \\
10.35\end{array}$ & $\begin{array}{l}40.9 \\
40.2\end{array}$ & $\begin{array}{l}14.3 \\
14.4\end{array}$ & $\begin{array}{l}0.59 \\
0.61\end{array}$ & $\begin{array}{l}3.13 \\
2.80\end{array}$ & $\begin{array}{l}0.20 \\
0.17\end{array}$ \\
\hline P-J-T-4 & 20 & $1: 1$ & 7 & & 10.08 & 39.6 & 11.3 & 0.37 & 1.21 & 0.10 \\
\hline P-J-T-5 & 20 & $1: 1$ & 7 & & 10.05 & 43.2 & 9.94 & 0.34 & 0.86 & 0.08 \\
\hline P-J-T-6 & 20 & $1: 1$ & 7 & & 10.16 & 40.6 & 10.2 & 0.33 & 1.20 & 0.08 \\
\hline P-J-T-7 & 20 & $1: 1$ & 7 & & 10.14 & 39.9 & 10.4 & 1.08 & 1.30 & 0.30 \\
\hline P-J-T-8 & 20 & $1: 1$ & 7 & & 10.10 & 39.2 & 9.30 & 1.11 & 1.06 & 0.30 \\
\hline \multirow[t]{4}{*}{ P-J-T-9 } & 20 & $1: 1$ & 7 & & 10.20 & 39.5 & 10.5 & 1.13 & 1.21 & 0.32 \\
\hline & & & & mean & 10.21 & 40.34 & 11.64 & 0.69 & 1.70 & 0.19 \\
\hline & & & & & 0.14 & 1.18 & 2.11 & 0.34 & 0.86 & 0.10 \\
\hline & & & & $\%$ rsd & 1.37 & 2.93 & 18.11 & 49.07 & 50.63 & 51.39 \\
\hline P-K-T-1 & 40 & $1: 1$ & 7 & & 10.60 & 82.3 & 42.3 & 4.21 & 6.30 & 0.61 \\
\hline P-K-T-2 & 40 & $1: 1$ & 7 & & 10.52 & 69.1 & 36.3 & 4.03 & 5.73 & 0.59 \\
\hline $\mathrm{P}-\mathrm{K}-\mathrm{T}-3$ & 40 & $1: 1$ & 7 & & 10.57 & 72.5 & 38.6 & 4.21 & 6.29 & 0.65 \\
\hline P-K-T-4 & 40 & $1: 1$ & 7 & & 10.39 & 78.7 & 33.0 & 3.63 & 3.28 & 0.23 \\
\hline P-K-T-5 & 40 & $1: 1$ & 7 & & 10.50 & 82.0 & 37.1 & 3.89 & 3.76 & 0.26 \\
\hline P-K-T-6 & 40 & $1: 1$ & 7 & & 10.46 & 73.5 & 32.1 & 3.54 & 3.89 & 0.58 \\
\hline $\mathrm{P}-\mathrm{K}-\mathrm{T}-7$ & 40 & $1: 1$ & 7 & & 10.53 & 76.1 & 34.1 & 4.45 & 4.88 & 0.81 \\
\hline P-K-T-8 & 40 & $1: 1$ & 7 & & 10.55 & 77.0 & 34.2 & 4.71 & 4.70 & 0.84 \\
\hline \multirow[t]{4}{*}{$P-K-T-9$} & 40 & $1: 1$ & 7 & & 10.55 & 77.4 & 35.2 & 4.59 & 4.51 & 0.82 \\
\hline & & & & mean & 10.52 & 76.52 & 35.87 & 4.14 & 4.82 & 0.60 \\
\hline & & & & & 0.06 & 4.32 & 3.16 & 0.41 & 1.10 & 0.22 \\
\hline & & & & $\%$ rsd & 0.61 & 5.65 & 8.80 & 9.84 & 22.80 & 37.53 \\
\hline P-L-T-1 & 70 & $1: 1$ & 7 & & 11.16 & 239 & 100 & 29.7 & 9.90 & 3.51 \\
\hline P-L-T-2 & 70 & $1: 1$ & 7 & & 11.16 & 239 & 102 & 30.5 & 10.6 & 3.67 \\
\hline P-L-T-3 & 70 & $1: 1$ & 7 & & 11.16 & 233 & 100 & 30.5 & 10.8 & 3.76 \\
\hline P-L-T-4 & 70 & $1: 1$ & 7 & & 11.06 & 228 & 88.3 & 24.4 & 7.44 & 2.28 \\
\hline P-L-T-5 & 70 & $1: 1$ & 7 & & 10.95 & 199 & 76.1 & 20.3 & 6.26 & 1.88 \\
\hline P-L-T-6 & 70 & $1: 1$ & 7 & & 11.08 & 247 & 94.7 & 25.5 & 7.50 & 2.32 \\
\hline P-L-T-7 & 70 & $1: 1$ & 7 & & 11.14 & 219 & 87.4 & 29.0 & 9.50 & 3.91 \\
\hline P-L-T-8 & 70 & $1: 1$ & 7 & & 11.15 & 218 & 90.8 & 29.4 & 9.08 & 4.01 \\
\hline \multirow[t]{4}{*}{ P-L-T-9 } & 70 & $1: 1$ & 7 & & 11.17 & 222 & 91.1 & 28.8 & 8.84 & 3.98 \\
\hline & & & & mean & 11.11 & 227.32 & 92.31 & 27.56 & 8.88 & 3.26 \\
\hline & & - & & & 0.07 & 14.48 & 8.15 & 3.45 & 1.54 & 0.85 \\
\hline & & & & $\%$ rsd & 0.65 & 6.37 & 8.83 & 12.50 & 17.30 & 25.95 \\
\hline
\end{tabular}

"Means, sample standard deviations, and relative standard deviations are calculated for three sets of triplicate tests. 
Table 11. Summary of Means and Standard Deviations for Replicate Tests

\begin{tabular}{lllllllll}
\hline $\begin{array}{l}\text { Temp. } \\
{\left[{ }^{\circ} \mathrm{C}\right]}\end{array}$ & $\begin{array}{l}\text { Glass/Water Time } \\
{[\mathrm{g} / \mathrm{g}]}\end{array}$ & $\begin{array}{l}\mathrm{pH} \\
{[\mathrm{d}]}\end{array}$ & & $\begin{array}{l}\mathrm{Na} \\
{[\mathrm{mg} / \mathrm{L}]}\end{array}$ & $\begin{array}{l}\mathrm{Si} \\
{[\mathrm{mg} / \mathrm{L}]}\end{array}$ & $\begin{array}{l}\mathrm{B} \\
{[\mathrm{mg} / \mathrm{L}]}\end{array}$ & $\begin{array}{l}\mathrm{Al} \\
{[\mathrm{mg} / \mathrm{L}]}\end{array}$ & $\begin{array}{l}\mathrm{K} \\
{[\mathrm{mg} / \mathrm{L}]}\end{array}$ \\
\hline 20 & $1: 10$ & 3 & $9.06 \pm 0.12$ & $5.22 \pm 0.22$ & $0.50 \pm 0.06$ & $0.09 \pm 0.03$ & $0.11 \pm 0.02$ & $<0.1$ \\
40 & $1: 10$ & 3 & $9.36 \pm 0.06$ & $10.06 \pm 0.67$ & $4.14 \pm 0.51$ & $0.42 \pm 0.09$ & $0.87 \pm 0.22$ & $0.18 \pm 0.05$ \\
70 & $1: 10$ & 3 & $9.69 \pm 0.06$ & $33.7 \pm 1.57$ & $24.7 \pm 1.75$ & $3.50 \pm 0.17$ & $5.03 \pm 0.43$ & $0.63 \pm 0.11$ \\
20 & $1: 1$ & 3 & $10.19 \pm 0.05$ & $35.7 \pm 2.4$ & $6.35 \pm 0.49$ & $0.64 \pm 0.21$ & $0.87 \pm 0.31$ & $0.28 \pm 0.10$ \\
40 & $1: 1$ & 3 & $10.36 \pm 0.07$ & $62.9 \pm 1.48$ & $25.2 \pm 1.15$ & $2.96 \pm 0.22$ & $4.11 \pm 0.50$ & $0.71 \pm 0.14$ \\
70 & $1: 1$ & 3 & $10.93 \pm 0.02$ & $194 \pm 14.4$ & $75.0 \pm 6.56$ & $20.6 \pm 1.40$ & $10.2 \pm 0.73$ & $3.12 \pm 0.43$ \\
20 & $1: 10$ & 7 & $9.13 \pm 0.23$ & $5.87 \pm 0.35$ & $1.03 \pm 0.19$ & $0.11 \pm 0.03$ & $0.21 \pm 0.09$ & $<0.1$ \\
40 & $1: 10$ & 7 & $9.41 \pm 0.10$ & $13.3 \pm 0.93$ & $8.90 \pm 0.95$ & $0.92 \pm 0.12$ & $1.69 \pm 0.38$ & $0.12 \pm 0.04$ \\
70 & $1: 10$ & 7 & $9.86 \pm 0.06$ & $43.4 \pm 1.82$ & $34.9 \pm 1.60$ & $4.67 \pm 0.45$ & $6.74 \pm 1.02$ & $0.75 \pm 0.14$ \\
20 & $1: 1$ & 7 & $10.21 \pm 0.14$ & $40.3 \pm 1.18$ & $11.6 \pm 2.11$ & $0.69 \pm 0.34$ & $1.70 \pm 0.86$ & $0.19 \pm 0.10$ \\
40 & $1: 1$ & 7 & $10.52 \pm 0.06$ & $76.5 \pm 4.32$ & $35.9 \pm 3.16$ & $4.14 \pm 0.41$ & $4.82 \pm 1.10$ & $0.60 \pm 0.22$ \\
70 & $1: 1$ & 7 & $11.11 \pm 0.07$ & $227 \pm 14.48$ & $92.3 \pm 8.15$ & $27.6 \pm 3.45$ & $8.88 \pm 1.54$ & $3.26 \pm 0.85$ \\
\hline
\end{tabular}


Table 12. Results of Triplicate ANSI/ANS 16.1 Tests Performed on LRM-1

\begin{tabular}{|c|c|c|c|c|c|c|c|}
\hline $\begin{array}{l}\text { Leach } \\
\text { Interval } \\
\text { (n) }\end{array}$ & $\begin{array}{c}\text { Incremental } \\
\text { Leaching } \\
\text { Time [s] } \\
\mathrm{Dt}_{\mathrm{n}}\end{array}$ & $\begin{array}{c}\text { Cumulative } \\
\text { Leaching } \\
\text { Time [s] } \\
\mathrm{t}\end{array}$ & $\begin{array}{l}\text { Conc. } \\
{[\mu \mathrm{g} / \mathrm{L}]}\end{array}$ & $\begin{array}{c}\text { Fraction } \\
\text { Released } \\
a_{N} / A_{0}\end{array}$ & $\begin{array}{l}\text { Release Rate } \\
\text { (fraction/s) } \\
\mathrm{a}_{n} / \mathrm{A}_{0} * 1 / \mathrm{D} t_{n}\end{array}$ & $\begin{array}{c}\text { Diffusivity } \\
{\left[\mathrm{cm}^{2} / \mathrm{s}\right]} \\
D\end{array}$ & $\begin{array}{c}\text { Leachability } \\
\text { Index } \\
\log (\mathrm{b} / \mathrm{D})\end{array}$ \\
\hline
\end{tabular}

sample 1

$\begin{array}{lccccccc}1 & 7200 & 7200 & 59.2 & 1.58 \times 10^{-5} & 2.20 \times 10^{-9} & 2.80 \times 10^{-16} & 15.55 \\ 2 & 18000 & 25200 & 84.6 & 2.26 \times 10^{-5} & 1.26 \times 10^{-9} & 7.53 \times 10^{-16} & 15.34 \\ 3 & 61200 & 86400 & 91.1 & 2.43 \times 10^{-5} & 3.98 \times 10^{-10} & 2.61 \times 10^{-16} & 15.42 \\ 4 & 86400 & 172800 & 110 & 2.94 \times 10^{-5} & 3.40 \times 10^{-10} & 9.35 \times 10^{-16} & 15.32 \\ 5 & 86400 & 259200 & 54.6 & 1.46 \times 10^{-5} & 1.69 \times 10^{-10} & 1.96 \times 10^{-16} & 15.40 \\ 6 & 86400 & 345600 & 94.3 & 2.52 \times 10^{-5} & 2.91 \times 10^{-10} & 8.23 \times 10^{-16} & 15.35 \\ 7 & 86400 & 432000 & 40.0 & 1.07 \times 10^{-5} & 1.24 \times 10^{-10} & 1.91 \times 10^{-16} & 15.39 \\ 8 & 1209600 & 1641600 & 271 & 7.24 \times 10^{-5} & 5.99 \times 10^{-11} & 8.76 \times 10^{-15} & 15.23 \\ 9 & 2419200 & 4060800 & 173 & 4.62 \times 10^{-5} & 1.91 \times 10^{-11} & 3.57 \times 10^{-15} & 15.14 \\ 10 & 3715200 & 7776000 & 162 & 4.33 \times 10^{-5} & 1.17 \times 10^{-11} & 3.13 \times 10^{-15} & 15.08\end{array}$

sample 2

$\begin{array}{lccccccc}1 & 7200 & 7200 & 54.2 & 1.45 \times 10^{-5} & 2.21 \times 10^{-9} & 2.34 \times 10^{-16} & 15.63 \\ 2 & 18000 & 25200 & 87.2 & 2.33 \times 10^{-5} & 1.29 \times 10^{-9} & 8.00 \times 10^{-16} & 15.36 \\ 3 & 61200 & 86400 & 73.5 & 1.96 \times 10^{-5} & 3.21 \times 10^{-10} & 1.70 \times 10^{-16} & 15.50 \\ 4 & 86400 & 172800 & 95.0 & 2.54 \times 10^{-5} & 2.94 \times 10^{-10} & 6.97 \times 10^{-16} & 15.41 \\ 5 & 86400 & 259200 & 64.9 & 1.73 \times 10^{-5} & 2.01 \times 10^{-10} & 2.77 \times 10^{-16} & 15.44 \\ 6 & 86400 & 345600 & 68.1 & 1.82 \times 10^{-5} & 2.11 \times 10^{-10} & 4.30 \times 10^{-16} & 15.43 \\ 7 & 86400 & 432000 & 47.3 & 1.26 \times 10^{-5} & 1.46 \times 10^{-10} & 2.67 \times 10^{-16} & 15.45 \\ 8 & 1209600 & 1641600 & 224 & 5.99 \times 10^{-5} & 4.95 \times 10^{-11} & 5.99 \times 10^{-15} & 15.30 \\ 9 & 2419200 & 4060800 & 175 & 4.68 \times 10^{-5} & 1.93 \times 10^{-11} & 3.65 \times 10^{-15} & 15.20 \\ 10 & 3715200 & 7776000 & 167 & 4.46 \times 10^{-5} & 1.20 \times 10^{-11} & 3.33 \times 10^{-15} & 15.13\end{array}$

sample 3

\begin{tabular}{lccccccc}
1 & 7200 & 7200 & 76.5 & $2.04 \times 10^{-5}$ & $2.84 \times 10^{-9}$ & $4.67 \times 10^{-16}$ & 15.33 \\
2 & 18000 & 25200 & 75.5 & $1.94 \times 10^{-5}$ & $1.08 \times 10^{-9}$ & $5.53 \times 10^{-16}$ & 15.29 \\
3 & 61200 & 86400 & 110 & $2.94 \times 10^{-5}$ & $4.80 \times 10^{-10}$ & $3.80 \times 10^{-16}$ & 15.34 \\
4 & 86400 & 172800 & 106 & $2.83 \times 10^{-5}$ & $3.28 \times 10^{-10}$ & $8.68 \times 10^{-16}$ & 15.27 \\
5 & 86400 & 259200 & 89.6 & $2.40 \times 10^{-5}$ & $2.77 \times 10^{-10}$ & $5.29 \times 10^{-16}$ & 15.27 \\
6 & 86400 & 345600 & 71.4 & $1.91 \times 10^{-5}$ & $2.21 \times 10^{-10}$ & $4.72 \times 10^{-16}$ & 15.28 \\
7 & 86400 & 432000 & 40.6 & $1.09 \times 10^{-5}$ & $1.26 \times 10^{-10}$ & $1.97 \times 10^{-16}$ & 15.34 \\
8 & 1209600 & 1641600 & 189 & $5.05 \times 10^{-5}$ & $4.18 \times 10^{-11}$ & $4.26 \times 10^{-15}$ & 15.22 \\
9 & 2419200 & 4060800 & 206 & $5.51 \times 10^{-5}$ & $2.28 \times 10^{-11}$ & $5.06 \times 10^{-15}$ & 15.16 \\
10 & 3715200 & 7776000 & 150 & $4.01 \times 10^{-5}$ & $1.08 \times 10^{-11}$ & $2.69 \times 10^{-15}$ & 15.06 \\
\hline
\end{tabular}

Results are based on Na releases.

Leachability Index is 15.3 .

Confidence Range (99.9\%) 15.2 - 15.4.

Correlation Coefficient 0.01 . 
Table 13. Results of Triplicate TCLP performed on LRM-1

\begin{tabular}{lllllll}
\hline Element & $\begin{array}{l}\text { TCPL-Blank } \\
{[\mathrm{mg} / \mathrm{L}]}\end{array}$ & $\begin{array}{l}\text { TCLP-1 } \\
{[\mathrm{mg} / \mathrm{L}]}\end{array}$ & $\begin{array}{l}\text { TCLP-2 } \\
{[\mathrm{mg} / \mathrm{L}]}\end{array}$ & $\begin{array}{l}\text { TCLP-3 } \\
{[\mathrm{mg} / \mathrm{L}]}\end{array}$ & $\begin{array}{l}\text { Regulatory } \\
\text { Level [mg/L] }\end{array}$ & Pass/Fail \\
\hline & & & & & & \\
$\mathrm{As}$ & $<0.2$ & $<0.2$ & $<0.2$ & $<0.2$ & 5.0 & pass \\
$\mathrm{Ba}$ & $<0.003$ & $<0.003$ & $<0.003$ & $<0.003$ & 100.0 & pass \\
$\mathrm{Cd}$ & $<0.009$ & 0.1 & 0.1 & 0.1 & 1.0 & pass \\
$\mathrm{Cr}$ & $<0.02$ & $<0.02$ & $<0.02$ & $<0.02$ & 5.0 & pass \\
$\mathrm{Pb}$ & $<0.005$ & 0.037 & 0.033 & 0.035 & 5.0 & pass \\
$\mathrm{Hg}$ & $<0.03$ & $<0.03$ & $<0.03$ & $<0.03$ & 0.2 & pass \\
$\mathrm{Se}$ & $<0.1$ & $<0.1$ & $<0.1$ & $<0.1$ & 1.0 & pass \\
$\mathrm{Ag}$ & $<0.002$ & $<0.002$ & $<0.002$ & $<0.002$ & 5.0 & pass \\
$\mathrm{Si}$ & $<2$ & $<2$ & $<2$ & $<2$ & N.A. & N.A \\
$\mathrm{B}$ & 2 & 0.9 & 0.8 & 0.8 & N.A & N.A \\
$\mathrm{Al}$ & $<0.06$ & $<0.06$ & $<0.06$ & $<0.06$ & N.A & N.A \\
& & & & & & \\
\hline
\end{tabular}
${ }^{2}$ Upper limits are calculated as 3.14 times the standard deviation of the instrumental blank. Concentrations are
not corrected for contribution of experimental blank to the leachate concentration. 
Table 14. One-Way ANOVA Tables for Concentrations of (a) $\mathrm{Na}$, (b) $\mathrm{Si}$, and (c) B, for results of all 12 PATs by Fixed-Effect Factors Temperature, Glass/Water Mass Ratio, Test Duration and Triplicate

(a)

Response: $\mathrm{Na}$ [ppb]

\begin{tabular}{|lr|}
\hline Summary of Fit & \\
RSquare & $\mathbf{0 . 8 0 0 2 3 4}$ \\
RSquare Adj & $\mathbf{0 . 7 8 8 3 6 7}$ \\
Root Mean Square Error & 32395.25 \\
Mean of Response & 62383.24 \\
Observations (or Sum Wgts) & 108 \\
\hline
\end{tabular}

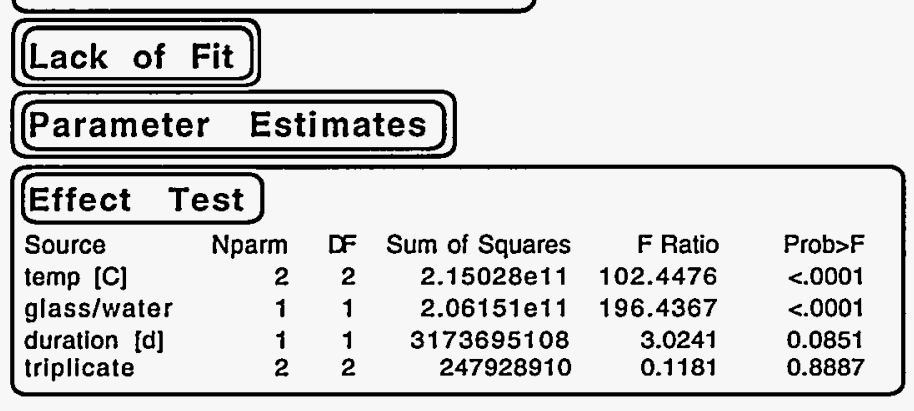

(b)

Response: Si [ppb]

\begin{tabular}{|lr|}
\hline Summary of Fit & \\
RSquare & 0.869049 \\
RSquare Adj & 0.86127 \\
Root Mean Square Error & 10651.67 \\
Mean of Response & 26707.61 \\
Observations (or Sum Wgts) & 108 \\
\hline
\end{tabular}

Lack of Fit

Parameter Estimates

\begin{tabular}{|lrrrrr|}
\hline Effect & Test & & & & \\
Source & Nparm & DF & Sum of Squares & F Ratio & ProbsF \\
temp [C] & 2 & 2 & $5.19987 e 10$ & 229.1536 & $<.0001$ \\
glass/water & 1 & 1 & 2.22271 e10 & 195.9055 & $<.0001$ \\
duration [d] & 1 & 1 & 1784787612 & 15.7308 & 0.0001 \\
triplicate & 2 & 2 & 38481700.6 & 0.1696 & 0.8443 \\
\hline
\end{tabular}


(c)

Response: B [ppb]

\begin{tabular}{|lr|}
\hline Summary of Fit & \\
RSquare & 0.714619 \\
RSquare Adj & 0.697666 \\
Root Mean Square Error & 4766.382 \\
Mean of Response & 5529.079 \\
Observations (or Sum Wgts) & 108 \\
\hline
\end{tabular}

Lack of Fit

Parameter Estimates

\begin{tabular}{|lrrrrr|}
\hline Effect & Test & & & & \\
Source & Nparm & DF & Sum of Squares & F Ratio & Prob $>F$ \\
temp [C] & 2 & 2 & 4012979469 & 88.3201 & $<.0001$ \\
glass/water & 1 & 1 & 1650963269 & 72.6708 & $<.0001$ \\
duration [d] & 1 & 1 & 72686876.4 & 3.1995 & 0.0767 \\
triplicate & 2 & 2 & 9140070.6 & 0.2012 & 0.8181 \\
\hline
\end{tabular}


Table 15. One-Way ANOVA Tables for Concentrations of (a) $\mathrm{Na}$, (b) $\mathrm{Si}$, and (c) B, for $20^{\circ} \mathrm{C}$, $40^{\circ} \mathrm{C}, 70^{\circ} \mathrm{C}, 3-$ Day, and 7-Day Tests by Glass/Water Mass Ratio

(a) $\mathrm{Na}$

\begin{tabular}{ccccc}
\hline $\begin{array}{c}\text { temp. } \\
{[\mathrm{C}]}\end{array}$ & $\begin{array}{c}\text { duration } \\
{[\mathrm{d}]}\end{array}$ & $\begin{array}{c}1: 1 \\
{[\mathrm{mg} / \mathrm{L}]}\end{array}$ & $\begin{array}{c}1: 10 \\
{[\mathrm{mg} / \mathrm{L}]}\end{array}$ & P-value \\
\hline & & & & \\
20 & 3 & 35.7 & 5.22 & $<0.0001$ \\
40 & 3 & 62.9 & 10.6 & $<0.0001$ \\
70 & 3 & 194 & 33.7 & $<0.0001$ \\
20 & 7 & 40.3 & 5.87 & $<0.0001$ \\
40 & 7 & 76.5 & 13.3 & $<0.0001$ \\
70 & 7 & 227 & 43.4 & $<0.0001$ \\
& & & & \\
\hline
\end{tabular}

(b) $\mathrm{Si}$

\begin{tabular}{ccccc}
\hline $\begin{array}{c}\text { temp. } \\
{[\mathrm{C}]}\end{array}$ & $\begin{array}{c}\text { duration } \\
{[\mathrm{d}]}\end{array}$ & $\begin{array}{c}1: 1 \\
{[\mathrm{mg} / \mathrm{L}]}\end{array}$ & $\begin{array}{c}1: 10 \\
{[\mathrm{mg} / \mathrm{L}]}\end{array}$ & P-value \\
\hline & & & & \\
20 & 3 & 6.35 & 0.50 & $<0.0001$ \\
40 & 3 & 25.2 & 4.14 & $<0.0001$ \\
70 & 3 & 75.0 & 24.7 & $<0.0001$ \\
20 & 7 & 11.6 & 1.03 & $<0.0001$ \\
40 & 7 & 35.9 & 8.90 & 0.0001 \\
70 & 7 & 92.3 & 34.9 & $<0.0001$ \\
\hline
\end{tabular}

(c) $\mathrm{B}$

\begin{tabular}{ccccr}
\hline $\begin{array}{c}\text { temp. } \\
{[\mathrm{C}]}\end{array}$ & $\begin{array}{c}\text { duration } \\
{[\mathrm{d}]}\end{array}$ & $\begin{array}{c}1: 1 \\
{[\mathrm{mg} / \mathrm{L}]}\end{array}$ & $\begin{array}{c}1: 10 \\
{[\mathrm{mg} / \mathrm{L}]}\end{array}$ & P-value \\
\hline & & & & \\
20 & 3 & 0.64 & 0.09 & $<0.0001$ \\
40 & 3 & 2.96 & 0.42 & $<0.0001$ \\
70 & 3 & 20.6 & 3.50 & $<0.0001$ \\
20 & 7 & 0.69 & 0.11 & 0.0001 \\
40 & 7 & 4.14 & 0.92 & $<0.0001$ \\
70 & 7 & 27.6 & 4.67 & $<0.0001$ \\
\hline
\end{tabular}


Table 16. One-Way ANOVA Tables for Concentrations of (a) $\mathrm{Na}$, (b) $\mathrm{Si}$, and (c) B, for 1:10, 1:1, 3-Day, and 7-Day Tests by Temperature

(a) $\mathrm{Na}$

\begin{tabular}{cccccc}
\hline $\begin{array}{c}\text { glass/water } \\
{[\mathrm{g} / \mathrm{g}]}\end{array}$ & $\begin{array}{c}\text { duration } \\
{[\mathrm{d}]}\end{array}$ & $\begin{array}{c}20^{\circ} \mathrm{C} \\
{[\mathrm{mg} / \mathrm{L}]}\end{array}$ & $\begin{array}{c}40^{\circ} \mathrm{C} \\
{[\mathrm{mg} / \mathrm{L}]}\end{array}$ & $\begin{array}{c}70^{\circ} \mathrm{C} \\
{[\mathrm{mg} / \mathrm{L}]}\end{array}$ & P-value \\
\hline & & & & & \\
$1: 10$ & 3 & 0.52 & 10.6 & 33.7 & $<0.0001$ \\
$1: 1$ & 3 & 35.7 & 62.9 & 194 & $<0.0001$ \\
$1: 10$ & 7 & 5.87 & 13.3 & 43.4 & $<0.0001$ \\
$1: 1$ & 7 & 40.3 & 76.5 & 227 & $<0.0001$ \\
& & & & & \\
\hline
\end{tabular}

(b) $\mathrm{Si}$

\begin{tabular}{cccccc}
\hline $\begin{array}{c}\text { glass/water } \\
{[\mathrm{g} / \mathrm{g}]}\end{array}$ & $\begin{array}{c}\text { duration } \\
{[\mathrm{d}]}\end{array}$ & $\begin{array}{c}20^{\circ} \mathrm{C} \\
{[\mathrm{mg} / \mathrm{L}]}\end{array}$ & $\begin{array}{c}40^{\circ} \mathrm{C} \\
{[\mathrm{mg} / \mathrm{L}]}\end{array}$ & $\begin{array}{c}70^{\circ} \mathrm{C} \\
{[\mathrm{mg} / \mathrm{L}]}\end{array}$ & P-value \\
\hline & & & & & \\
$1: 10$ & 3 & 0.50 & 4.14 & 24.7 & $<0.0001$ \\
$1: 1$ & 3 & 6.35 & 25.2 & 75.0 & $<0.0001$ \\
$1: 10$ & 7 & 1.03 & 8.90 & 34.9 & $<0.0001$ \\
$1: 1$ & 7 & 11.6 & 35.9 & 92.3 & $<0.0001$ \\
\hline
\end{tabular}

(c) $\mathrm{B}$

\begin{tabular}{cccccc}
\hline $\begin{array}{c}\text { glass/water } \\
{[\mathrm{g} / \mathrm{g}]}\end{array}$ & $\begin{array}{c}\text { duration } \\
{[\mathrm{d}]}\end{array}$ & $\begin{array}{c}20^{\circ} \mathrm{C} \\
{[\mathrm{mg} / \mathrm{L}]}\end{array}$ & $\begin{array}{c}40^{\circ} \mathrm{C} \\
{[\mathrm{mg} / \mathrm{L}]}\end{array}$ & $\begin{array}{c}70^{\circ} \mathrm{C} \\
{[\mathrm{mg} / \mathrm{L}]}\end{array}$ & P-value \\
\hline & & & & & \\
$1: 10$ & 3 & 0.09 & 0.42 & 3.50 & $<0.0001$ \\
$1: 1$ & 3 & 0.64 & 2.96 & 20.6 & $<0.0001$ \\
$1: 10$ & 7 & 0.11 & 0.92 & 4.67 & $<0.0001$ \\
$1: 1$ & 7 & 0.69 & 4.14 & 27.5 & $<0.0001$ \\
\hline
\end{tabular}


Table 17. One-Way ANOVA Tables for Concentrations of (a) Na, (b) Si, and (c) B for 1:1, 1:10, 3-Day, and 7-Day Tests by Duration

(a) $\mathrm{Na}$

\begin{tabular}{ccccc}
\hline $\begin{array}{c}\text { temp. } \\
{[\mathrm{C}]}\end{array}$ & $\begin{array}{c}\text { glass/water } \\
{[\mathrm{g} / \mathrm{g}]}\end{array}$ & $\begin{array}{c}3-\mathrm{d} \\
{[\mathrm{mg} / \mathrm{L}]}\end{array}$ & $\begin{array}{c}7-\mathrm{d} \\
{[\mathrm{mg} / \mathrm{L}]}\end{array}$ & P-value \\
\hline & & & & \\
20 & $1: 10$ & 5.22 & 5.87 & 0.0002 \\
40 & $1: 10$ & 10.6 & 13.3 & $<0.0001$ \\
70 & $1: 10$ & 33.7 & 43.4 & $<0.0001$ \\
20 & $1: 1$ & 35.7 & 40.3 & $<0.0001$ \\
40 & $1: 1$ & 62.9 & 76.5 & $<0.0001$ \\
70 & $1: 1$ & 194 & 227 & $<0.0001$ \\
& & & & \\
\hline
\end{tabular}

(b) $\mathrm{Si}$

\begin{tabular}{ccccc}
\hline $\begin{array}{c}\text { temp. } \\
{[\mathrm{C}]}\end{array}$ & $\begin{array}{c}\text { glass/water } \\
{[\mathrm{g} / \mathrm{g}]}\end{array}$ & $\begin{array}{c}3-\mathrm{d} \\
{[\mathrm{mg} / \mathrm{L}]}\end{array}$ & $\begin{array}{c}7-\mathrm{d} \\
{[\mathrm{mg} / \mathrm{L}]}\end{array}$ & P-value \\
\hline & & & & \\
20 & $1: 10$ & 0.50 & 1.03 & $<0.0001$ \\
40 & $1: 10$ & 4.14 & 8.90 & $<0.0001$ \\
70 & $1: 10$ & 24.7 & 34.9 & $<0.0001$ \\
20 & $1: 1$ & 6.35 & 11.6 & $<0.0001$ \\
40 & $1: 1$ & 25.2 & 35.9 & $<0.0001$ \\
70 & $1: 1$ & 75.0 & 92.3 & 0.0001 \\
& & & & \\
\hline
\end{tabular}

(c) $\mathrm{B}$

\begin{tabular}{ccccr}
\hline $\begin{array}{c}\text { temp. } \\
{[\mathrm{C}]}\end{array}$ & $\begin{array}{c}\text { glass/water } \\
{[\mathrm{g} / \mathrm{g}]}\end{array}$ & $\begin{array}{c}3-\mathrm{d} \\
{[\mathrm{mg} / \mathrm{L}]}\end{array}$ & $\begin{array}{c}7-\mathrm{d} \\
{[\mathrm{mg} / \mathrm{L}]}\end{array}$ & P-value \\
\hline & & & & \\
20 & $1: 10$ & 0.09 & 0.11 & 0.1399 \\
40 & $1: 10$ & 0.42 & 0.92 & $<0.0001$ \\
70 & $1: 10$ & 3.49 & 4.67 & $<0.0001$ \\
20 & $1: 1$ & 0.64 & 0.69 & 0.7572 \\
40 & $1: 1$ & 2.96 & 4.14 & $<0.0001$ \\
70 & $1: 1$ & 20.6 & 27.6 & $<0.0001$ \\
& & & & \\
\hline
\end{tabular}


Table 18. One-Way ANOVA Tables for Concentrations of (a) Na, (b) Si, and (c) B for 1:1, 1:10, $20^{\circ} \mathrm{C}, 40^{\circ} \mathrm{C}, 70^{\circ} \mathrm{C}, 3-\mathrm{Day}$, and 7-Day Tests by Triplicate

(a) $\mathrm{Na}$

\begin{tabular}{lccccccc}
\hline Designation & $\begin{array}{c}\text { temp. } \\
\text { [C] }\end{array}$ & $\begin{array}{c}\text { glass/water } \\
{[\mathrm{g} / \mathrm{g}]}\end{array}$ & $\begin{array}{c}\text { duration } \\
\text { [d] }\end{array}$ & $\begin{array}{c}\text { rep. 1-3 } \\
{[\mathrm{mg} / \mathrm{L}]}\end{array}$ & $\begin{array}{c}\text { rep. 4-6 } \\
{[\mathrm{mg} / \mathrm{L}]}\end{array}$ & $\begin{array}{c}\text { rep. 7-9 } \\
{[\mathrm{mg} / \mathrm{L}]}\end{array}$ & P-value \\
\hline & & & & & & & \\
P-A-T & 20 & $1: 10$ & 3 & 5.04 & 5.30 & 5.32 & 0.2454 \\
P-B-T & 40 & $1: 10$ & 3 & 10.9 & 11.1 & 9.85 & 0.0207 \\
P-C-T & 70 & $1: 10$ & 3 & 32.9 & 34.9 & 33.3 & 0.2966 \\
P-D-T & 20 & $1: 1$ & 3 & 33.4 & 38.3 & 35.5 & 0.0063 \\
P-E-T & 40 & $1: 1$ & 3 & 62.5 & 62.6 & 63.6 & 0.6472 \\
P-F-T & 70 & $1: 1$ & 3 & 193 & 208 & 180 & 0.0308 \\
P-G-T & 20 & $1: 10$ & 7 & 5.53 & 6.22 & 5.86 & 0.0182 \\
P-H-T & 40 & $1: 10$ & 7 & 13.7 & 14.0 & 12.2 & 0.0069 \\
P-I-T & 70 & $1: 10$ & 7 & 44.0 & 44.1 & 42.2 & 0.4121 \\
P-J-T & 20 & $1: 1$ & 7 & 40.3 & 41.1 & 39.6 & 0.3016 \\
P-K-T & 40 & $1: 1$ & 7 & 74.6 & 78.1 & 76.8 & 0.6726 \\
P-L-T & 70 & $1: 1$ & 7 & 237 & 225 & 220 & 0.3634 \\
& & & & & & & \\
\hline
\end{tabular}

(b) $\mathrm{Si}$

\begin{tabular}{lccccccr}
\hline Designation & $\begin{array}{c}\text { temp. } \\
{[\mathrm{C}]}\end{array}$ & $\begin{array}{c}\text { glass/water } \\
{[\mathrm{g} / \mathrm{g}]}\end{array}$ & $\begin{array}{c}\text { duration } \\
{[\mathrm{d}]}\end{array}$ & $\begin{array}{r}\text { rep. 1-3 } \\
{[\mathrm{mg} / \mathrm{L}]}\end{array}$ & $\begin{array}{r}\text { rep. 4-6 } \\
{[\mathrm{mg} / \mathrm{L}]}\end{array}$ & $\begin{array}{r}\text { rep. 7-9 } \\
{[\mathrm{mg} / \mathrm{L}]}\end{array}$ & P-value \\
\hline & & & & & & & \\
P-A-T & 20 & $1: 10$ & 3 & 0.54 & 0.48 & 0.48 & 0.4675 \\
P-B-T & 40 & $1: 10$ & 3 & 4.78 & 3.74 & 3.88 & 0.0006 \\
P-C-T & 70 & $1: 10$ & 3 & 22.9 & 24.5 & 26.7 & 0.0024 \\
P-D-T & 20 & $1: 1$ & 3 & 6.90 & 6.12 & 6.04 & 0.0255 \\
P-E-T & 40 & $1: 1$ & 3 & 24.5 & 25.0 & 26.0 & 0.3184 \\
P-F-T & 70 & $1: 1$ & 3 & 69.0 & 79.4 & 76.5 & 0.1175 \\
P-G-T & 20 & $1: 10$ & 7 & 1.28 & 0.93 & 0.88 & $<0.0001$ \\
P-H-T & 40 & $1: 10$ & 7 & 9.92 & 8.68 & 8.09 & 0.0208 \\
P-I-T & 70 & $1: 10$ & 7 & 36.4 & 33.9 & 34.3 & 0.1088 \\
P-J-T & 20 & $1: 1$ & 7 & 14.4 & 10.5 & 10.1 & 0.0002 \\
P-K-T & 40 & $1: 1$ & 7 & 39.1 & 34.1 & 34.5 & 0.0760 \\
P-L-T & 70 & $1: 1$ & 7 & 101 & 86.4 & 89.8 & 0.0456 \\
& & & & & & & \\
\hline
\end{tabular}


(c) $\mathrm{B}$

\begin{tabular}{|c|c|c|c|c|c|c|c|}
\hline Designation & $\begin{array}{l}\text { temp. } \\
\text { [C] }\end{array}$ & $\begin{array}{c}\text { glass/water } \\
{[\mathrm{g} / \mathrm{g}]}\end{array}$ & $\begin{array}{c}\text { duration } \\
\text { [d] }\end{array}$ & $\begin{array}{r}\text { rep. 1-3 } \\
{[\mathrm{mg} / \mathrm{L}]}\end{array}$ & $\begin{array}{r}\text { rep. 4-6 } \\
{[\mathrm{mg} / \mathrm{L}]} \\
\end{array}$ & $\begin{array}{r}\text { rep. 7-9 } \\
{[\mathrm{mg} / \mathrm{L}]}\end{array}$ & P-value \\
\hline P-A-T & 20 & $1: 10$ & 3 & 0.064 & 0.087 & 0.123 & $<0.0001$ \\
\hline P-B-T & 40 & $1: 10$ & 3 & 0.370 & 0.350 & 0.529 & 0.0005 \\
\hline P-C-T & 70 & $1: 10$ & 3 & 3.56 & 3.29 & 3.65 & 0.0005 \\
\hline P-D-T & 20 & $1: 1$ & 3 & 0.428 & 0.608 & 0.899 & $<0.0001$ \\
\hline P-E-T & 40 & $1: 1$ & 3 & 2.78 & 2.96 & 3.15 & 0.0898 \\
\hline P-F-T & 70 & $1: 1$ & 3 & 19.9 & 21.8 & 20.2 & 0.2207 \\
\hline P-G-T & 20 & $1: 10$ & 7 & 0.095 & 0.087 & 0.157 & $<0.0001$ \\
\hline P-H-T & 40 & $1: 10$ & 7 & 1.01 & 0.76 & 1.00 & $<0.0001$ \\
\hline P-I-T & 70 & $1: 10$ & 7 & 4.99 & 4.08 & 4.95 & $<0.0001$ \\
\hline P-J-T & 20 & $1: 1$ & 7 & 0.609 & 0.342 & 1.11 & $<0.0001$ \\
\hline P-K-T & 40 & $1: 1$ & 7 & 4.15 & 3.69 & 4.58 & 0.0007 \\
\hline P-L-T & 70 & $1: 1$ & 7 & 30.2 & 23.4 & 29.1 & 0.0043 \\
\hline
\end{tabular}


Table 19. One-Way ANOVA Tables for Concentrations of (a) $\mathrm{Na}$, and (b) $\mathrm{Si}$ for 1:10, $40^{\circ} \mathrm{C}$, $70^{\circ} \mathrm{C}$, 3-Day, and 7-Day Tests by Replicate Analysis

(a) $\mathrm{Na}$

\begin{tabular}{lccccccc}
\hline Designation & $\begin{array}{c}\text { temp. } \\
{[\mathrm{C}]}\end{array}$ & $\begin{array}{c}\text { glass/water } \\
{[\mathrm{g} / \mathrm{g}]}\end{array}$ & $\begin{array}{c}\text { duration } \\
{[\mathrm{d}]}\end{array}$ & $\begin{array}{c}\text { analysis } \\
{[\mathrm{mg} / \mathrm{L}]}\end{array}$ & $\begin{array}{c}\text { analysis 2 } \\
{[\mathrm{mg} / \mathrm{L}]}\end{array}$ & $\begin{array}{c}\text { relative } \\
\text { error (\%) }\end{array}$ & P-value \\
\hline & & & & & & & \\
P-B-T & 40 & $1: 10$ & 3 & 10.6 & 9.77 & 7.83 & 0.0084 \\
P-C-T & 70 & $1: 10$ & 3 & 33.7 & 31.4 & 6.82 & 0.0032 \\
P-H-T & 40 & $1: 10$ & 7 & 13.3 & 13.3 & 0.00 & 0.9226 \\
P-I-T & 70 & $1: 10$ & 7 & 43.4 & 41.8 & 3.69 & 0.0409 \\
& & & & & & & \\
\hline
\end{tabular}

(b) $\mathrm{Si}$

\begin{tabular}{lccccccc}
\hline Designation & $\begin{array}{c}\text { temp. } \\
{[\mathrm{C}]}\end{array}$ & $\begin{array}{c}\text { glass/water } \\
{[\mathrm{g} / \mathrm{g}]}\end{array}$ & $\begin{array}{c}\text { duration } \\
{[\mathrm{d}]}\end{array}$ & $\begin{array}{c}\text { analysis 1 } \\
{[\mathrm{mg} / \mathrm{L}]}\end{array}$ & $\begin{array}{c}\text { analysis 2 } \\
{[\mathrm{mg} / \mathrm{L}]}\end{array}$ & $\begin{array}{c}\text { relative } \\
\text { error (\%) }\end{array}$ & P-value \\
\hline & & & & & & & \\
P-B-T & 40 & $1: 10$ & 3 & 4.14 & 4.24 & -2.42 & 0.6952 \\
P-C-T & 70 & $1: 10$ & 3 & 24.7 & 26.3 & -6.48 & 0.1108 \\
P-H-T & 40 & $1: 10$ & 7 & 8.90 & 8.53 & 4.16 & 0.4137 \\
P-I-T & 70 & $1: 10$ & 7 & 34.9 & 34.0 & 2.58 & 0.1833 \\
& & & & & & & \\
\hline
\end{tabular}


Table 20. Comparisons of the Percent Relative Standard Deviation of Measured Concentrations of $\mathrm{Na}, \mathrm{Si}$, and $\mathrm{B}$ in Replicate Tests with Respect to (a) Test Duration, (b) Glass/Water Mass Ratio, and (c) Temperature.

(a) Duration

\begin{tabular}{|c|c|c|c|c|c|c|c|}
\hline \multirow[b]{2}{*}{$\begin{array}{l}\text { temp. } \\
{\left[{ }^{\circ} \mathrm{C}\right]}\end{array}$} & \multirow[b]{2}{*}{$\begin{array}{c}\text { glass/water } \\
{[\mathrm{g} / \mathrm{g}]}\end{array}$} & \multicolumn{2}{|c|}{$\mathrm{Na}[\% \mathrm{sd}]$} & \multicolumn{2}{|c|}{ Si[\%rsd] } & \multicolumn{2}{|c|}{$\mathrm{B}[\% \mathrm{rsd}]$} \\
\hline & & 3-day & 7-day & 3-day & 7-day & 3-day & 7-day \\
\hline 20 & $1: 10$ & 4.18 & 5.93 & 12.5 & 18.4 & 28.3 & 29.4 \\
\hline 40 & $1: 10$ & 6.33 & 6.95 & 12.4 & 10.7 & 21.2 & 13.0 \\
\hline 70 & $1: 10$ & 4.66 & 4.18 & 7.10 & 4.59 & 4.81 & 9.73 \\
\hline 20 & $1: 1$ & 6.60 & 2.93 & 7.73 & 18.1 & 32.4 & 49.1 \\
\hline 40 & $1: 1$ & 2.35 & 5.65 & 4.55 & 8.80 & 7.28 & 9.84 \\
\hline 70 & $1: 1$ & 7.41 & 6.37 & 8.75 & 8.83 & 6.77 & 12.5 \\
\hline
\end{tabular}

(b) Glass/Water Mass Ratio

\begin{tabular}{|c|c|c|c|c|c|c|c|}
\hline \multirow[b]{2}{*}{$\begin{array}{l}\text { temp. } \\
{\left[{ }^{\circ} \mathrm{C}\right]}\end{array}$} & \multirow[b]{2}{*}{$\begin{array}{l}\text { time } \\
\text { [d] }\end{array}$} & \multicolumn{2}{|c|}{$\mathrm{Na}[\% \mathrm{rsd}]$} & \multicolumn{2}{|c|}{ Si[\%rsd] } & \multicolumn{2}{|c|}{$\mathrm{B}[\% \mathrm{rsd}]$} \\
\hline & & $1: 10$ & $1: 1$ & $1: 10$ & $1: 1$ & $1: 10$ & $1: 1$ \\
\hline 20 & 3 & 4.18 & 6.60 & 12.5 & 7.73 & 28.3 & 32.4 \\
\hline 40 & 3 & 6.33 & 2.35 & 12.4 & 4.55 & 21.2 & 7.28 \\
\hline 70 & 3 & 4.66 & 7.41 & 7.10 & 8.75 & 4.81 & 6.77 \\
\hline 20 & 7 & 5.93 & 2.93 & 18.4 & 18.1 & 29.4 & 49.1 \\
\hline 40 & 7 & 6.95 & 5.65 & 10.7 & 8.80 & 13.0 & 9.84 \\
\hline 70 & 7 & 4.18 & 6.37 & 4.59 & 8.83 & 9.73 & 12.5 \\
\hline
\end{tabular}

(c) Temperature

\begin{tabular}{|c|c|c|c|c|c|c|c|c|c|c|}
\hline \multirow[b]{2}{*}{$\begin{array}{l}\text { time } \\
\text { [d] }\end{array}$} & \multirow[b]{2}{*}{$\begin{array}{c}\text { glass } / \text { water } \\
{[\mathrm{g} / \mathrm{g}]}\end{array}$} & \multicolumn{3}{|c|}{$\mathrm{Na}[\% \mathrm{rsd}]$} & \multicolumn{3}{|c|}{$\mathrm{Si}[\% \mathrm{rsd}]$} & \multicolumn{3}{|c|}{$\mathrm{B}[\% \mathrm{rsd}]$} \\
\hline & & $20^{\circ} \mathrm{C}$ & $40^{\circ} \mathrm{C}$ & $70^{\circ} \mathrm{C}$ & $20^{\circ} \mathrm{C}$ & $40^{\circ} \mathrm{C}$ & $70^{\circ} \mathrm{C}$ & $20^{\circ} \mathrm{C}$ & $40^{\circ} \mathrm{C}$ & $70^{\circ} \mathrm{C}$ \\
\hline 3 & $1: 10$ & 4.18 & 6.33 & 4.66 & 12.53 & 12.37 & 7.10 & 28.3 & 21.2 & 4.81 \\
\hline 3 & $1: 1$ & 6.60 & 2.35 & 7.41 & 7.73 & 4.55 & 8.75 & 32.4 & 7.28 & 6.77 \\
\hline 7 & $1: 10$ & 5.93 & 6.95 & 4.18 & 18.37 & 10.70 & 4.59 & 29.4 & 13.0 & 9.73 \\
\hline 7 & $1: 1$ & 2.93 & 5.65 & 6.37 & 18.11 & 8.80 & 8.83 & 49.7 & 9.84 & 12.5 \\
\hline
\end{tabular}


Table 21. Results of F-test Comparisons of the Normalized Standard Deviations of Na, $\mathrm{Si}$, and $\mathrm{B}$ Concentrations. Comparisons are for (a) $541: 1$ vs. $541: 10$ glass/water mass ratio tests (b) 36 $20^{\circ} \mathrm{C}$ vs. $3640^{\circ} \mathrm{C}$ tests (c) $3620^{\circ} \mathrm{C}$ vs. $3670^{\circ} \mathrm{C}$ tests (d) $3640^{\circ} \mathrm{C}$ vs. $3670^{\circ} \mathrm{C}$ tests and (e) $543-$ day vs. 547 -day duration tests. The null hypothesis is tested at the $95 \%$ significance level.

(a) Glass/Water Mass Ratio

\begin{tabular}{lcccc}
\hline Element & $\mathrm{s}$ & $\mathrm{s}$ & $\begin{array}{c}\text { F-value } \\
\text { calculated }\end{array}$ & $\begin{array}{c}\text { Significant } \\
(\mathrm{y} / \mathrm{n})\end{array}$ \\
\hline $\mathrm{ga} / \mathrm{g}]$ & $\begin{array}{c}1: 10 \\
{[\mathrm{~g} / \mathrm{g}]}\end{array}$ & & \\
$\mathrm{Si}$ & 0.0375 & 0.0323 & 1.36 & $\mathrm{n}$ \\
$\mathrm{B}$ & 0.0482 & 0.0529 & 1.22 & $\mathrm{n}$ \\
& 0.0434 & 0.0295 & 2.16 & $\mathrm{y}$ \\
\hline
\end{tabular}

(b) $20^{\circ} \mathrm{C}$ vs. $40^{\circ} \mathrm{C}$

\begin{tabular}{lcccc}
\hline Element & $\begin{array}{c}\mathrm{S} \\
20^{\circ} \mathrm{C}\end{array}$ & $\begin{array}{c}\mathrm{s} \\
40^{\circ} \mathrm{C}\end{array}$ & $\begin{array}{c}\text { F-value } \\
\text { calculated }\end{array}$ & $\begin{array}{c}\text { Significant } \\
(\mathrm{y} / \mathrm{n})\end{array}$ \\
\hline & & & & \\
$\mathrm{Na}$ & 0.0279 & 0.0355 & 1.62 & $\mathrm{n}$ \\
$\mathrm{Si}$ & 0.0617 & 0.0449 & 1.89 & $\mathrm{n}$ \\
$\mathrm{B}$ & 0.0350 & 0.0383 & 1.20 & $\mathrm{n}$ \\
\hline
\end{tabular}

(c) $20^{\circ} \mathrm{C}$ vs. $70^{\circ} \mathrm{C}$

\begin{tabular}{lcccc}
\hline Element & $\mathrm{s}$ & $\mathrm{s}$ & $\begin{array}{c}\text { F-value } \\
\text { calculated }\end{array}$ & $\begin{array}{c}\text { Significant } \\
(\mathrm{y} / \mathrm{n})\end{array}$ \\
\hline $\mathrm{Na}$ & $20^{\circ} \mathrm{C}$ & $70^{\circ} \mathrm{C}$ & & \\
$\mathrm{Si}$ & 0.0279 & 0.0409 & 2.15 & $\mathrm{n}$ \\
$\mathrm{B}$ & 0.0617 & .0449 & 1.40 & $\mathrm{n}$ \\
& 0.0350 & 0.0384 & 1.20 & $\mathrm{n}$ \\
\hline
\end{tabular}

(d) $40^{\circ} \mathrm{C}$ vs. $70^{\circ} \mathrm{C}$

\begin{tabular}{lcccc}
\hline Element & $\mathrm{S}$ & $\mathrm{s}$ & $\begin{array}{c}\text { F-value } \\
\text { calculated }\end{array}$ & $\begin{array}{c}\text { Significant } \\
(\mathrm{y} / \mathrm{n})\end{array}$ \\
\hline & $40^{\circ} \mathrm{C}$ & $70{ }^{\circ} \mathrm{C}$ & & \\
$\mathrm{Na}$ & & & & $\mathrm{n}$ \\
$\mathrm{Si}$ & 0.0355 & 0.0409 & 1.33 & $\mathrm{n}$ \\
$\mathrm{B}$ & 0.0449 & 0.0440 & 1.04 & $\mathrm{n}$ \\
\hline
\end{tabular}


(e) Duration

\begin{tabular}{lcccc}
\hline Element & $\begin{array}{c}\mathrm{s} \\
\text { 3-day }\end{array}$ & $\begin{array}{c}\mathrm{s} \\
\text { 7-day }\end{array}$ & $\begin{array}{c}\text { F-value } \\
\text { calculated }\end{array}$ & $\begin{array}{c}\text { Significant } \\
(\mathrm{y} / \mathrm{n})\end{array}$ \\
\hline & & & & \\
$\mathrm{Na}$ & 0.0316 & 0.0380 & 1.41 & $\mathrm{n}$ \\
$\mathrm{Si}$ & 0.0540 & 0.0470 & 1.32 & $\mathrm{n}$ \\
$\mathrm{B}$ & 0.0402 & 0.0337 & 1.38 & $\mathrm{n}$ \\
\hline
\end{tabular}


Table 22. Calculated Average Normalized Dissolution Rates

\begin{tabular}{lllllllll}
\hline $\begin{array}{l}\text { temp. } \\
{\left[{ }^{\circ} \mathrm{C}\right]}\end{array}$ & $\begin{array}{l}\text { glass/water } \\
{[\mathrm{g} / \mathrm{g}]}\end{array}$ & $\begin{array}{l}\text { time } \\
{[\mathrm{d}]}\end{array}$ & $\mathrm{pH}$ & $\begin{array}{l}\mathrm{NR}(\mathrm{Na}), \\
{\left[\mathrm{g} /\left(\mathrm{m}^{2} \bullet \mathrm{d}\right)\right]}\end{array}$ & $\begin{array}{l}\mathrm{NR}(\mathrm{Si}), \\
{\left[\mathrm{g} /\left(\mathrm{m}^{2} \cdot \mathrm{d}\right)\right]}\end{array}$ & $\begin{array}{l}\mathrm{NR}(\mathrm{B}), \\
{\left[\mathrm{g} /\left(\mathrm{m}^{2} \cdot \mathrm{d}\right)\right]}\end{array}$ & $\begin{array}{l}\mathrm{NR}(\mathrm{Al}), \\
{\left[\mathrm{g} /\left(\mathrm{m}^{2} \cdot \mathrm{d}\right)\right]}\end{array}$ & $\begin{array}{l}\mathrm{NR}(\mathrm{K}), \\
{\left[\mathrm{g} /\left(\mathrm{m}^{2} \cdot \mathrm{d}\right)\right]}\end{array}$ \\
\hline 20 & $1: 10$ & 3 & 9.06 & $6.53 \times 10^{-3}$ & $0.317 \times 10^{-3}$ & $0.567 \times 10^{-3}$ & $0.344 \times 10^{-3}$ & $<1.6 \times 10^{-3}$ \\
40 & $1: 10$ & 3 & 9.36 & $12.6 \times 10^{-3}$ & $2.63 \times 10^{-3}$ & $2.65 \times 10^{-3}$ & $2.72 \times 10^{-3}$ & $2.29 \times 10^{-3}$ \\
70 & $1: 10$ & 3 & 9.69 & $42.1 \times 10^{-3}$ & $15.6 \times 10^{-3}$ & $22.0 \times 10^{-3}$ & $15.7 \times 10^{-3}$ & $10.0 \times 10^{-3}$ \\
20 & $1: 1$ & 3 & 10.19 & $4.34 \times 10^{-3}$ & $0.403 \times 10^{-3}$ & $0.403 \times 10^{-3}$ & $0.272 \times 10^{-3}$ & $0.445 \times 10^{-3}$ \\
40 & $1: 1$ & 3 & 10.36 & $7.87 \times 10^{-3}$ & $1.60 \times 10^{-3}$ & $1.86 \times 10^{-3}$ & $1.28 \times 10^{-3}$ & $1.13 \times 10^{-3}$ \\
70 & $1: 1$ & 3 & 10.93 & $24.2 \times 10^{-3}$ & $4.57 \times 10^{-3}$ & $13.0 \times 10^{-3}$ & $3.19 \times 10^{-3}$ & $4.95 \times 10^{-3}$ \\
20 & $1: 10$ & 7 & 9.13 & $3.15 \times 10^{-3}$ & $0.280 \times 10^{-3}$ & $0.297 \times 10^{-3}$ & $0.281 \times 10^{-3}$ & $<0.69 \times 10^{-3}$ \\
40 & $1: 10$ & 7 & 9.41 & $7.12 \times 10^{-3}$ & $2.42 \times 10^{-3}$ & $2.46 \times 10^{-3}$ & $2.26 \times 10^{-3}$ & $0.816 \times 10^{-3}$ \\
70 & $1: 10$ & 7 & 9.86 & $23.2 \times 10^{-3}$ & $9.50 \times 10^{-3}$ & $12.6 \times 10^{-3}$ & $9.03 \times 10^{-3}$ & $5.10 \times 10^{-3}$ \\
20 & $1: 1$ & 7 & 10.21 & $2.16 \times 10^{-3}$ & $0.316 \times 10^{-3}$ & $0.186 \times 10^{-3}$ & $0.228 \times 10^{-3}$ & $0.129 \times 10^{-3}$ \\
40 & $1: 1$ & 7 & 10.52 & $4.10 \times 10^{-3}$ & $0.976 \times 10^{-3}$ & $1.12 \times 10^{-3}$ & $0.646 \times 10^{-3}$ & $0.409 \times 10^{-3}$ \\
70 & $1: 1$ & 7 & 11.11 & $12.1 \times 10^{-3}$ & $2.50 \times 10^{-3}$ & $7.45 \times 10^{-3}$ & $1.19 \times 10^{-3}$ & $2.21 \times 10^{-3}$ \\
\hline
\end{tabular}


APPENDIX A. ANALYSES OF LRM-1

Table A-1. Results of Analyses of Dissolved Samples of LRM-1 ${ }^{\mathrm{a}}$

\begin{tabular}{|c|c|c|c|c|c|c|c|c|c|c|c|c|c|c|c|c|c|}
\hline element & ACL-1 & ACL-2 & SFW-1 & SFW-2 & SFW-3 & SFW-4 & SFW-5 & SFW-6 & SFW-7 & SFW-8 & SFW-9 & SFW-10 & SFW-11 & SFW-12 & SFW-13 & SFW-14 & SFW-15 \\
\hline $\mathrm{Al} 2 \mathrm{O} 3$ & 10.47 & ND & 8.69 & 8.76 & 8.86 & 9.08 & 9.26 & 9.25 & 9.69 & 9.71 & 9.64 & 10.19 & 10.30 & 10.18 & 9.97 & 9.96 & 9.97 \\
\hline $\mathrm{B} 2 \mathrm{O} 3$ & 8.08 & ND & 7.26 & 7.29 & 7.31 & 7.90 & 7.54 & 7.35 & 7.54 & 7.33 & 7.53 & ND & ND & ND & ND & ND & ND \\
\hline $\mathrm{BaO}$ & 0.01 & ND & ND & ND & ND & 0.01 & 0.01 & 0.01 & 0.01 & 0.01 & 0.01 & 0.01 & 0.01 & 0.01 & 0.01 & 0.01 & 0.01 \\
\hline $\mathrm{CaO}$ & 0.51 & ND & ND & ND & ND & ND & ND & ND & ND & ND & ND & 0.45 & 0.39 & 0.38 & 0.35 & 0.35 & 0.35 \\
\hline $\mathrm{CdO}$ & 0.17 & ND & 0.18 & 0.18 & 0.17 & 0.17 & 0.17 & 0.17 & 0.18 & 0.18 & 0.18 & 0.16 & 0.16 & 0.16 & 0.16 & 0.16 & 0.16 \\
\hline $\mathrm{a}$ & ND & 1.09 & ND & ND & ND & ND & ND & ND & ND & ND & ND & ND & ND & ND & ND & ND & ND \\
\hline $\mathrm{Cr} 2 \mathrm{O} 3$ & 0.20 & ND & 0.30 & 0.28 & 0.24 & 0.16 & 0.15 & 0.15 & 0.16 & 0.16 & 0.16 & 0.11 & 0.11 & 0.11 & 0.25 & 0.25 & 0.14 \\
\hline $\mathrm{F}$ & ND & 0.85 & ND & ND & ND & ND & ND & ND & ND & ND & ND & ND & ND & ND & ND & ND & ND \\
\hline $\mathrm{Fe} 2 \mathrm{O} 3$ & 1.04 & ND & 1.20 & 1.21 & 1.06 & 0.91 & 0.92 & 0.92 & 1.00 & 0.97 & 0.97 & 1.01 & 0.98 & 0.99 & 0.98 & 0.98 & 0.97 \\
\hline $\mathrm{Hg})$ & ND & ND & ND & ND & ND & ND & ND & ND & ND & ND & ND & 0.00 & 0.00 & 0.00 & 0.00 & 0.00 & 0.00 \\
\hline I & ND & ND & ND & ND & ND & $2.13 \mathrm{E}-03$ & $2.54 \mathrm{E}-03$ & $2.26 \mathrm{E}-03$ & $2.63 \mathrm{E}-03$ & $2.85 \mathrm{E}-03$ & $2.74 \mathrm{E}-03$ & ND & ND & ND & ND & ND & ND \\
\hline $\mathrm{K} 2 \mathrm{O}$ & 1.35 & ND & 1.30 & 1.27 & 1.26 & 0.92 & 0.89 & 0.89 & 0.97 & 0.94 & 0.94 & 1.50 & 1.57 & 1.55 & 1.54 & 1.54 & 1.55 \\
\hline $\mathrm{La} 2 \mathrm{O} 3$ & ND & ND & ND & ND & ND & ND & ND & ND & ND & ND & ND & 0.01 & 0.01 & 0.01 & 0.01 & 0.01 & 0.01 \\
\hline $\mathrm{Li2O}$ & 0.09 & ND & 0.11 & 0.11 & 0.11 & 0.05 & 0.04 & 0.04 & 0.04 & 0.04 & 0.04 & 0.12 & 0.11 & 0.11 & 0.10 & 0.10 & 0.10 \\
\hline $\mathrm{MgO}$ & 0.11 & ND & 0.10 & 0.10 & 0.09 & 0.06 & 0.05 & 0.05 & 0.05 & 0.05 & 0.05 & 0.11 & 0.11 & 0.11 & 0.11 & 0.11 & 0.11 \\
\hline Mno & 0.09 & ND & 0.14 & 0.13 & 0.12 & 0.08 & 0.08 & 0.08 & 0.08 & 0.08 & 0.08 & 0.08 & 0.08 & 0.08 & 0.08 & 0.08 & 0.08 \\
\hline $\mathrm{MoO} 3$ & 0.10 & ND & 0.15 & 0.14 & 0.10 & 0.10 & 0.10 & 0.09 & 0.10 & 0.10 & 0.10 & 0.08 & 0.08 & 0.08 & 0.07 & 0.08 & 0.07 \\
\hline $\mathrm{Na} 2 \mathrm{O}$ & 17.25 & ND & 15.37 & 15.65 & 15.95 & 16.70 & 16.31 & 15.89 & 16.47 & 15.81 & 16.26 & ND & ND & ND & ND & ND & ND \\
\hline $\mathrm{NiO}$ & 0.09 & ND & 0.11 & 0.11 & 0.10 & 0.06 & 0.06 & 0.06 & 0.07 & 0.07 & 0.07 & 0.08 & 0.08 & 0.08 & 0.09 & 0.09 & 0.09 \\
\hline P2O5 & ND & 0.47 & 0.40 & 0.39 & 0.34 & 0.37 & 0.36 & 0.36 & 0.38 & 0.38 & 0.37 & ND & ND & ND & ND & ND & ND \\
\hline $\mathrm{PbO}$ & 0.09 & ND & 0.14 & 0.14 & 0.13 & 0.10 & 0.10 & 0.10 & 0.10 & 0.10 & 0.10 & 0.10 & 0.10 & 0.10 & 0.09 & 0.09 & 0.09 \\
\hline $\mathrm{SO} 3$ & ND & 0.20 & ND & ND & ND & ND & ND & ND & ND & ND & ND & ND & ND & ND & ND & ND & ND \\
\hline $\mathrm{SiO} 2$ & 51.56 & $N D$ & 52.35 & 53.41 & 53.66 & ND & ND & ND & ND & ND & ND & ND & ND & ND & ND & ND & ND \\
\hline $\mathrm{SnO} 2$ & 0.09 & ND & 0.11 & 0.11 & 0.11 & 0.09 & 0.12 & 0.09 & 0.09 & 0.09 & 0.09 & ND & ND & ND & ND & ND & ND \\
\hline TiO2 & 0.11 & ND & 0.11 & 0.11 & 0.10 & 0.09 & 0.09 & 0.09 & 0.10 & 0.09 & 0.10 & 0.10 & 0.09 & 0.10 & 0.09 & 0.09 & 0.09 \\
\hline $\mathrm{ZrO} 2$ & 0.99 & ND & 1.48 & 1.42 & 1.34 & ND & 0.96 & 0.93 & 0.97 & 0.98 & 0.98 & 0.65 & 0.64 & 0.63 & 0.58 & 0.57 & 0.57 \\
\hline $\begin{array}{c}\text { sample } \\
\text { technique }\end{array}$ & $\begin{array}{c}\text { CVDI } \\
\text { ICP-AES }\end{array}$ & $\begin{array}{c}\text { FXI } \\
\text { IC }\end{array}$ & $\begin{array}{c}\text { CVDI } \\
\text { ICP-MS }\end{array}$ & $\begin{array}{l}\text { CVD1 } \\
\text { ICP-MS }\end{array}$ & $\begin{array}{c}\text { CVD1 } \\
\text { ICP-MS }\end{array}$ & $\begin{array}{c}\text { CVD2 } \\
\text { ICP-MS }\end{array}$ & $\begin{array}{c}\text { CVD2 } \\
\text { ICP-MS }\end{array}$ & $\begin{array}{c}\text { CVD2 } \\
\text { ICP-MS }\end{array}$ & $\begin{array}{c}\text { CVD3 } \\
\text { ICP-MS }\end{array}$ & $\begin{array}{c}\text { CVD3 } \\
\text { ICP-MS }\end{array}$ & $\begin{array}{c}\text { CVD3 } \\
\text { ICP-MS }\end{array}$ & $\begin{array}{c}\text { OVD1 } \\
\text { ICP-MS }\end{array}$ & $\begin{array}{c}\text { OVDI } \\
\text { ICP-MS }\end{array}$ & $\begin{array}{c}\text { OVDI } \\
\text { ICP-MS }\end{array}$ & $\begin{array}{c}\text { OVDI } \\
\text { ICP-MS }\end{array}$ & $\begin{array}{c}\text { OVDI } \\
\text { ICP-MS } \\
\end{array}$ & $\begin{array}{c}\text { OVDI } \\
\text { ICP-MS }\end{array}$ \\
\hline
\end{tabular}

${ }^{a}$ Results notated in italics were not used in calculation of the reported mean composition of LRM-1, which is given in Table 5 


\section{APPENDIX B. TEST INITIATION AND TERMINATION DATA FOR PATS AND BLANKS}

Table B-1. Test Data for Experimental Blanks.

\begin{tabular}{|c|c|c|c|c|c|c|c|c|c|}
\hline Designation & $\begin{array}{c}\text { glass mass } \\
{[\mathrm{g}]} \\
\end{array}$ & $\begin{array}{c}\text { water mass } \\
{[\mathrm{g}]} \\
\end{array}$ & $\begin{array}{c}\text { pre-test } \\
\text { vessel mass } \\
{[\mathrm{g}]} \\
\end{array}$ & $\begin{array}{c}\text { post-test } \\
\text { vessel mass } \\
{[\mathrm{g}]}\end{array}$ & $\begin{array}{c}\text { LPE tare } \\
{[\mathrm{g}]} \\
\end{array}$ & $\begin{array}{c}\text { LPE+soln } \\
\text { [g] }\end{array}$ & $\begin{array}{c}\text { LPE+soln+acid } \\
{[\mathrm{g}]}\end{array}$ & $\begin{array}{c}\text { total soln } \\
{[\mathrm{g}]}\end{array}$ & $\mathrm{df}$ \\
\hline P-A-B-1 & 0.00 & 10.00 & 324.64 & 324.64 & 10.79 & 19.92 & 20.03 & 9.24 & 1.01 \\
\hline P-A-B-2 & 0.00 & 10.00 & 325.13 & 325.13 & 10.64 & 19.66 & 19.76 & 9.12 & 1.01 \\
\hline P-A-B-3 & 0.00 & 10.00 & 324.34 & 324.34 & 10.98 & 20.02 & 20.12 & 9.14 & 1.01 \\
\hline P-B-B-1 & 0.00 & 10.00 & 324.83 & 324.84 & 11.06 & 20.31 & 20.41 & 9.35 & 1.01 \\
\hline P-B-B-2 & 0.00 & 10.00 & 323.95 & 323.95 & 10.51 & 19.66 & 19.76 & 9.25 & 1.01 \\
\hline P-B-B-3 & 0.00 & 10.00 & 325.05 & 325.05 & 10.64 & 19.77 & 19.87 & 9.23 & 1.01 \\
\hline P-C-B-1 & 0.00 & 10.00 & 325.13 & 325.12 & 10.84 & 20.09 & 20.19 & 9.35 & 1.01 \\
\hline P-C-B-2 & 0.00 & 10.00 & 324.80 & 324.79 & 10.66 & 19.86 & 19.96 & 9.30 & 1.01 \\
\hline P-C-B-3 & 0.00 & 10.00 & 324.20 & 324.20 & 11.04 & 20.11 & 20.21 & 9.17 & 1.01 \\
\hline P-D-B-1 & 0.00 & 5.00 & 320.14 & 320.15 & 10.75 & 14.76 & 14.86 & 4.11 & 1.02 \\
\hline P-D-B-2 & 0.00 & 5.00 & 319.78 & 319.78 & 10.48 & 14.57 & 14.67 & 4.19 & 1.02 \\
\hline P-D-B-3 & 0.00 & 5.00 & 319.11 & 319.11 & 10.88 & 14.99 & 15.10 & 4.22 & 1.03 \\
\hline P-E-B-1 & 0.00 & 5.00 & 319.90 & 319.90 & 10.78 & 14.87 & 14.97 & 4.19 & 1.02 \\
\hline P-E-B-2 & 0.00 & 5.00 & 319.99 & 319.99 & 10.66 & 14.83 & 14.93 & 4.27 & 1.02 \\
\hline P-E-B-3 & 0.00 & 5.00 & 319.67 & 319.67 & 11.07 & 15.32 & 15.42 & 4.35 & 1.02 \\
\hline P-F-B-1 & 0.00 & 5.00 & 321.70 & 321.69 & 10.84 & 14.87 & 14.96 & 4.12 & 1.02 \\
\hline P-F-B-2 & 0.00 & 5.00 & 319.57 & 319.56 & 11.08 & 15.29 & 15.39 & 4.31 & 1.02 \\
\hline P-F-B-3 & 0.00 & 5.00 & 320.10 & 320.09 & 10.76 & 14.95 & 15.04 & 4.28 & 1.02 \\
\hline P-G-B-1 & 0.00 & 10.01 & 324.41 & 324.41 & 10.67 & 19.67 & 19.77 & 9.10 & 1.01 \\
\hline P-G-B-2 & 0.00 & 10.00 & 324.59 & 324.59 & 10.65 & 19.73 & 19.83 & 9.18 & 1.01 \\
\hline P-G-B-3 & 0.00 & 10.01 & 324.49 & 324.48 & 10.84 & 19.96 & 20.06 & 9.22 & 1.01 \\
\hline P-H-B-1 & 0.00 & 10.01 & 324.69 & 324.69 & 10.51 & 19.67 & 19.77 & 9.26 & 1.01 \\
\hline P-H-B-2 & 0.00 & 10.00 & 323.99 & 324.00 & 10.76 & 19.91 & 20.01 & 9.25 & 1.01 \\
\hline P-H-B-3 & 0.00 & 10.00 & 324.50 & 324.49 & 10.90 & 20.05 & 20.15 & 9.25 & 1.01 \\
\hline P-I-B-1 & 0.00 & 10.00 & 324.30 & 324.30 & 10.93 & 20.08 & 20.18 & 9.25 & 1.01 \\
\hline P-I-B-2 & 0.00 & 10.00 & 324.20 & 324.19 & 11.00 & 20.14 & 20.23 & 9.23 & 1.01 \\
\hline P-I-B-3 & 0.00 & 10.00 & 324.68 & 324.67 & 10.62 & 19.82 & 19.93 & 9.31 & 1.01 \\
\hline P-J-B-1 & 0.00 & 5.00 & 319.02 & 319.02 & 10.51 & 14.58 & 14.68 & 4.17 & 1.02 \\
\hline P-J-B-2 & 0.00 & 5.00 & 318.85 & 318.86 & 10.90 & 15.05 & 15.15 & 4.25 & 1.02 \\
\hline P-J-B-3 & 0.00 & 5.00 & 320.86 & 320.88 & 10.63 & 14.76 & 14.86 & 4.23 & 1.02 \\
\hline P-K-B-1 & 0.00 & 5.00 & 319.47 & 319.47 & 10.44 & 14.55 & 14.66 & 4.22 & 1.03 \\
\hline P-K-B-2 & 0.00 & 5.00 & .321 .48 & 321.48 & 10.89 & 15.03 & 15.13 & 4.24 & 1.02 \\
\hline P-K-B-3 & 0.00 & 5.00 & 319.39 & 319.38 & 10.95 & 15.14 & 15.23 & 4.28 & 1.02 \\
\hline P-L-B-1 & 0.00 & 5.00 & 320.07 & 320.06 & 10.64 & 14.83 & 14.93 & 4.29 & 1.02 \\
\hline P-L-B-2 & 0.00 & 5.00 & 319.99 & 319.99 & 10.46 & 14.65 & 14.76 & 4.30 & 1.03 \\
\hline P-L-B-3 & 0.00 & 5.00 & 319.68 & 319.66 & 10.97 & 15.20 & 15.30 & 4.33 & 1.02 \\
\hline
\end{tabular}


Table B-2. Test Initiation and Termination Data for PATs

\begin{tabular}{|c|c|c|c|c|c|c|c|c|c|}
\hline Designation & $\begin{array}{c}\text { glass mass } \\
{[\mathrm{g}]} \\
\end{array}$ & $\begin{array}{c}\text { water mass } \\
{[\mathrm{g}]}\end{array}$ & $\begin{array}{c}\text { pre-test } \\
\text { vessel mass } \\
\text { [g] }\end{array}$ & $\begin{array}{c}\text { post-test } \\
\text { vessel mass } \\
\cdot[\mathrm{g}] \\
\end{array}$ & $\begin{array}{l}\text { LPE tare } \\
{[\mathrm{g}]}\end{array}$ & $\begin{array}{c}\text { LPE+soln } \\
\text { [g] }\end{array}$ & $\begin{array}{c}\text { LPE+soln+acid } \\
{[\mathrm{g}]}\end{array}$ & $\begin{array}{c}\text { total soln } \\
\text { [g] }\end{array}$ & $\mathrm{df}$ \\
\hline P-A-T-1 & 1.00 & 10.01 & 325.70 & 325.70 & 10.92 & 19.69 & 19.79 & 8.87 & 1.01 \\
\hline P-A-T-2 & 1.00 & 10.00 & 324.57 & 324.58 & 10.86 & 19.43 & 19.54 & 8.68 & 1.01 \\
\hline P-A-T-3 & 1.00 & 10.00 & 324.82 & 324.82 & 11.11 & 19.73 & 19.86 & 8.75 & 1.02 \\
\hline P-A-T-4 & 1.00 & 10.00 & 325.59 & 325.59 & 10.51 & 19.21 & 19.32 & 8.81 & 1.01 \\
\hline P-A-T-S & 1.00 & 10.00 & 325.37 & 325.38 & 10.53 & 19.27 & 19.37 & 8.84 & 1.01 \\
\hline P-A-T-6 & 1.00 & 10.00 & 325.28 & 325.28 & 10.66 & 19.38 & 19.48 & 8.82 & 1.01 \\
\hline P-A-T-7 & 1.00 & 10.00 & 325.31 & 323.32 & 10.64 & 19.42 & 19.53 & 8.89 & 1.01 \\
\hline P-A-T-8 & 1.00 & 10.00 & 324.74 & 324.74 & 10.86 & 19.57 & 19.67 & 8.81 & 1.01 \\
\hline P-A-T-9 & 1.00 & 10.00 & 325.18 & 325.19 & 10.77 & 19.53 & 19.63 & 8.86 & 1.01 \\
\hline P-B-T-1 & 1.00 & 10.01 & 325.45 & 325.44 & 10.89 & 19.53 & 19.63 & 8.74 & 1.01 \\
\hline P-B-T-2 & 1.00 & 10.00 & 325.76 & 325.76 & 10.82 & 19.57 & 19.67 & 8.85 & 1.01 \\
\hline P-B-T-3 & 1.00 & 10.00 & 324.76 & 324.76 & 10.77 & 19.55 & 19.66 & 8.89 & 1.01 \\
\hline P-B-T-4 & 1.00 & 10.00 & 325.73 & 325.73 & 10.52 & 19.31 & 19.41 & 8.89 & 1.01 \\
\hline P-B-T-5 & 1.00 & 10.00 & 325.53 & 325.52 & 10.47 & 19.26 & 19.36 & 8.89 & 1.01 \\
\hline P-B-T-6 & 1.00 & 10.00 & 325.43 & 325.42 & 10.63 & 19.39 & 19.49 & 8.86 & 1.01 \\
\hline P-B-T-7 & 1.00 & 10.00 & 325.42 & 324.41 & 10.89 & 19.66 & 19.76 & 8.87 & 1.01 \\
\hline P-B-T-8 & 1.00 & 10.00 & 325.65 & 325.64 & 10.98 & 19.37 & 19.47 & 8.49 & 1.01 \\
\hline P-B-T-9 & 1.00 & 10.00 & 324.84 & 324.85 & 10.68 & 19.37 & 19.47 & 8.79 & 1.01 \\
\hline P-C-T-1 & 1.00 & 10.00 & 325.33 & 325.33 & 11.02 & 19.85 & 19.95 & 8.93 & 1.01 \\
\hline P-C-T-2 & 1.00 & 10.00 & 324.90 & 324.89 & 11.04 & 19.71 & 19.81 & 8.77 & 1.01 \\
\hline P-C-T-3 & 1.00 & 10.00 & 324.67 & 324.67 & 10.83 & 19.32 & 19.42 & 8.59 & 1.01 \\
\hline P-C-T-4 & 1.00 & 10.00 & 323.23 & 323.22 & 10.67 & 19.47 & 19.57 & 8.90 & 1.01 \\
\hline P-C-T-5 & 1.00 & 10.01 & 325.00 & 324.99 & 10.50 & 19.21 & 19.30 & 8.80 & 1.01 \\
\hline P-C-T-6 & 1.00 & 10.00 & 325.00 & 324.99 & 10.53 & 19.37 & 19.46 & 8.93 & 1.01 \\
\hline P-C-T-7 & 1.00 & 10.00 & 323.22 & 323.22 & 10.99 & 19.82 & 19.92 & 8.93 & 1.01 \\
\hline P-C-T-8 & 1.00 & 10.00 & 324.98 & 324.98 & 10.88 & 19.69 & 19.79 & 8.91 & 1.01 \\
\hline P-C-T-9 & 1.00 & 10.00 & 325.79 & 325.79 & 11.05 & 19.85 & 19.95 & 8.90 & 1.01 \\
\hline
\end{tabular}


Table B-2, contd. Test Initiation and Termination Data for PATs

\begin{tabular}{|c|c|c|c|c|c|c|c|c|c|}
\hline Designation & $\begin{array}{c}\text { glass mass } \\
{[\mathrm{g}]} \\
\end{array}$ & $\begin{array}{c}\text { water mass } \\
{[\mathrm{g}]}\end{array}$ & $\begin{array}{c}\text { pre-test } \\
\text { vessel mass } \\
\text { [g] }\end{array}$ & $\begin{array}{c}\text { post-test } \\
\text { vessel mass } \\
{[\mathrm{g}]} \\
\end{array}$ & $\begin{array}{c}\text { LPE tare } \\
{[\mathrm{g}]}\end{array}$ & $\begin{array}{c}\text { LPE+soln } \\
{[\mathrm{g}]}\end{array}$ & $\begin{array}{c}\text { LPE+soln+acid } \\
{[\mathrm{g}]}\end{array}$ & $\begin{array}{c}\text { total soln } \\
{[\mathrm{g}]}\end{array}$ & df \\
\hline P-D-T-1 & 5.00 & 5.00 & 324.57 & 324.58 & 10.76 & 13.25 & 13.35 & 2.59 & 1.04 \\
\hline P-D-T-2 & 5.00 & 5.00 & 324.33 & 324.34 & 10.88 & 13.38 & 13.48 & 2.60 & 1.04 \\
\hline P-D-T-3 & 5.00 & 5.00 & 324.45 & 324.46 & 10.88 & 13.44 & 13.54 & 2.66 & 1.04 \\
\hline P-D-T-4 & 5.00 & 5.00 & 324.63 & 324.63 & 10.52 & 12.96 & 13.06 & 2.54 & 1.04 \\
\hline P-D-T-5 & 5.00 & 5.00 & 324.82 & 324.83 & 10.57 & 13.07 & 13.18 & 2.61 & 1.04 \\
\hline P-D-T-6 & 5.00 & 5.00 & 325.30 & 325.31 & 10.52 & 13.02 & 13.12 & 2.60 & 1.04 \\
\hline P-D-T-7 & 5.00 & 5.00 & 324.95 & 324.96 & 10.87 & 13.46 & 13.56 & 2.69 & 1.04 \\
\hline P-D-T-8 & 5.00 & 5.00 & 323.77 & 323.78 & 10.87 & 13.49 & 13.59 & 2.72 & 1.04 \\
\hline P-D-T-9 & 5.00 & 5.00 & 324.47 & 324.47 & 10.82 & 13.43 & 13.53 & 2.71 & 1.04 \\
\hline P-E-T-I & 5.00 & 5.00 & 324.65 & 324.65 & 10.98 & 13.73 & 13.83 & 2.85 & 1.04 \\
\hline P-E-T-2 & 5.00 & 5.00 & 323.79 & 323.76 & 10.85 & 13.40 & 13.50 & 2.65 & 1.04 \\
\hline P-E-T-3 & 5.00 & 5.00 & 324.52 & 324.52 & 11.00 & 13.60 & 13.69 & 2.69 & 1.03 \\
\hline P-E-T-4 & 5.00 & 5.00 & 324.80 & 324.79 & 10.80 & 13.42 & 13.51 & 2.71 & 1.03 \\
\hline P-E-T-5 & 5.00 & 5.00 & 323.99 & 323.98 & 11.00 & 13.60 & 13.70 & 2.70 & 1.04 \\
\hline P-E-T-6 & 5.00 & 5.00 & 323.69 & 323.69 & 10.63 & 13.26 & 13.36 & 2.73 & 1.04 \\
\hline P-E-T-7 & 5.00 & 5.00 & 324.73 & 324.73 & 10.80 & 13.42 & 13.52 & 2.72 & 1.04 \\
\hline P-E-T-8 & 5.00 & 5.00 & 324.10 & 324.09 & 10.72 & 13.32 & 13.42 & 2.70 & 1.04 \\
\hline P-E-T-9 & 5.00 & 5.00 & 324.04 & 324.04 & 10.99 & 13.64 & 13.74 & 2.75 & 1.04 \\
\hline P-F-T-1 & 5.00 & 5.00 & 324.42 & 324.42 & 11.05 & 13.58 & 13.67 & 2.62 & 1.04 \\
\hline P-F-T-2 & 5.00 & 5.00 & 324.37 & 324.36 & 10.88 & 13.47 & 13.58 & 2.70 & 1.04 \\
\hline P-F-T-3 & 5.00 & 5.00 & 324.19 & 324.18 & 10.86 & 13.44 & 13.54 & 2.68 & 1.04 \\
\hline P-F-T-4 & 5.00 & 5.00 & 324.87 & 324.87 & 10.59 & 13.21 & 13.32 & 2.73 & 1.04 \\
\hline P-F-T-5 & 5.00 & 5.00 & 323.70 & 323.69 & 11.04 & 13.71 & 13.81 & 2.77 & 1.04 \\
\hline P-F-T-6 & 5.00 & 5.00 & 324.30 & 324.30 & 10.98 & 13.58 & 13.68 & 2.70 & 1.04 \\
\hline P-F-T-7 & 5.00 & 5.00 & 324.80 & 324.80 & 11.00 & 13.69 & 13.79 & 2.79 & 1.04 \\
\hline P-F-T-8 & 5.00 & 5.00 & 324.52 & 324.52 & 10.90 & 13.57 & 13.67 & 2.77 & 1.04 \\
\hline P-F-T-9 & 5.00 & 5.00 & 324.77 & 324.77 & 10.93 & 13.57 & 13.67 & 2.74 & 1.04 \\
\hline
\end{tabular}


Table B-2, contd. Test Initiation and Termination Data for PATs

\begin{tabular}{|c|c|c|c|c|c|c|c|c|c|}
\hline Designation & $\begin{array}{c}\text { glass mass } \\
{[\mathrm{g}]}\end{array}$ & $\begin{array}{c}\text { water mass } \\
{[\mathrm{g}]}\end{array}$ & $\begin{array}{c}\text { pre-test } \\
\text { vessel mass } \\
{[\mathrm{g}]}\end{array}$ & $\begin{array}{c}\text { post-test } \\
\text { vessel mass } \\
{[\mathrm{g}]}\end{array}$ & $\begin{array}{l}\text { LPE tare } \\
{[\mathrm{g}]}\end{array}$ & $\begin{array}{c}\text { LPE+soln } \\
{[\mathrm{g}]}\end{array}$ & $\begin{array}{c}\text { LPE+soln+acid } \\
{[\mathrm{g}]}\end{array}$ & $\begin{array}{c}\text { total soln } \\
{[\mathrm{g}]}\end{array}$ & df \\
\hline P-G-T-I & 1.00 & 10.00 & 324.93 & 324.93 & 10.50 & 19.27 & 19.38 & 8.88 & 1.01 \\
\hline P-G-T-2 & 1.00 & 10.00 & 325.02 & 325.02 & 10.54 & 19.01 & 19.11 & 8.57 & 1.01 \\
\hline P-G-T-3 & 1.00 & 10.00 & 324.62 & 324.62 & 10.59 & 19.32 & 19.42 & 8.83 & 1.01 \\
\hline P-G-T-4 & 1.00 & 10.00 & 325.18 & 325.19 & 10.89 & 19.60 & 19.70 & 8.81 & 1.01 \\
\hline P-G-T-5 & 1.00 & 10.00 & 324.99 & 325.00 & 10.81 & 19.49 & 19.59 & 8.78 & 1.01 \\
\hline P-G-T-6 & 1.00 & 10.00 & 324.75 & 324.76 & 10.51 & 19.17 & 19.26 & 8.75 & 1.01 \\
\hline P-G-T-7 & 1.00 & 10.00 & 325.20 & 325.21 & 11.02 & 19.75 & 19.86 & 8.84 & 1.01 \\
\hline P-G-T-8 & 1.00 & 10.00 & 324.97 & 324.96 & 11.11 & 19.93 & 20.03 & 8.92 & 1.01 \\
\hline P-G-T-9 & 1.00 & 10.00 & 324.91 & 324.92 & 10.87 & 19.68 & 19.78 & 8.91 & 1.01 \\
\hline P-H-T-I & 1.00 & 10.00 & 325.85 & 325.84 & 10.56 & 19.32 & 19.42 & 8.86 & 1.01 \\
\hline P-H-T-2 & 1.00 & 10.01 & 325.70 & 325.70 & 10.48 & 19.05 & 19.15 & 8.67 & 1.01 \\
\hline P-H-T-3 & 1.00 & 10.01 & 326.63 & 326.62 & 10.47 & 19.05 & 19.16 & 8.69 & 1.01 \\
\hline P-H-T-4 & 1.00 & 10.00 & 326.16 & 326.16 & 10.77 & 19.55 & 19.65 & 8.88 & 1.01 \\
\hline P-H-T-5 & 1.00 & 10.00 & 324.60 & 324.60 & 10.91 & 19.70 & 19.80 & 8.89 & 1.01 \\
\hline P-H-T-6 & 1.00 & 10.00 & 325.78 & 325.78 & 10.98 & 19.66 & 19.78 & 8.80 & 1.01 \\
\hline P-H-T-7 & 1.00 & 10.00 & 325.76 & 323.75 & 10.87 & 19.65 & 19.75 & 8.88 & 1.01 \\
\hline P-H-T-8 & 1.00 & 10.00 & 325.28 & 325.27 & 10.80 & 19.56 & 19.66 & 8.86 & 1.01 \\
\hline P-H-T-9 & 1.00 & 10.00 & 325.14 & 325.15 & 10.88 & 19.67 & 19.77 & 8.89 & 1.01 \\
\hline P-I-T-1 & 1.00 & 10.00 & 325.80 & 325.80 & 10.56 & 19.35 & 19.46 & 8.90 & 1.01 \\
\hline P-I-T-2 & 1.00 & 10.00 & 325.42 & 325.41 & 10.54 & 19.25 & 19.35 & 8.81 & 1.01 \\
\hline P-I-T-3 & 1.00 & 10.00 & 325.12 & 325.12 & 11.04 & 19.73 & 19.83 & 8.79 & 1.01 \\
\hline P-I-T-4 & 1.00 & 10.00 & 325.46 & 324.45 & 10.91 & 19.74 & 19.84 & 8.93 & 1.01 \\
\hline P-I-T-5 & 1.00 & 10.03 & 325.21 & 325.21 & 11.00 & 19.28 & 19.39 & 8.39 & 1.01 \\
\hline P-I-T-6 & 1.00 & 10.00 & 325.12 & 325.11 & 10.73 & 19.50 & 19.60 & 8.87 & 1.01 \\
\hline P-I-T-7 & 1.00 & 10.00 & 325.37 & 325.37 & 11.04 & 19.80 & 19.90 & 8.86 & 1.01 \\
\hline P-I-T-8 & 1.00 & 10.00 & 325.37 & 325.37 & 11.00 & 19.79 & 19.90 & 8.90 & 1.01 \\
\hline P-I-T-9 & 1.00 & 10.00 & 324.13 & 324.12 & 10.74 & 19.60 & 19.70 & 8.96 & 1.01 \\
\hline
\end{tabular}


Table B-2, contd. Test Initiation and Termination Data for PATs

\begin{tabular}{|c|c|c|c|c|c|c|c|c|c|}
\hline Designation & $\begin{array}{c}\text { glass mass } \\
{[\mathrm{g}]} \\
\end{array}$ & $\begin{array}{c}\text { water mass } \\
{[\mathrm{g}]}\end{array}$ & $\begin{array}{c}\text { pre-test } \\
\text { vessel mass } \\
\text { [g] }\end{array}$ & $\begin{array}{c}\text { post-test } \\
\text { vessel mass } \\
{[\mathrm{g}]}\end{array}$ & $\begin{array}{c}\text { LPE tare } \\
{[\mathrm{g}]}\end{array}$ & $\begin{array}{c}\text { LPE+soln } \\
{[\mathrm{g}]}\end{array}$ & $\begin{array}{c}\text { LPE+soln+acid } \\
{[\mathrm{g}]}\end{array}$ & $\begin{array}{c}\text { total soln } \\
{[\mathrm{g}]}\end{array}$ & $\mathrm{df}$ \\
\hline P-J-T-1 & 5.00 & 5.00 & 323.80 & 323.80 & 10.65 & 13.2 & 13.3 & 2.64 & 1.04 \\
\hline P-J-T-2 & 5.00 & 5.00 & 324.94 & 324.94 & 10.61 & 13.1 & 13.2 & 2.57 & 1.04 \\
\hline P-J-T-3 & 5.00 & 5.00 & 324.27 & 324.27 & 10.45 & 13.0 & 13.1 & 2.62 & 1.04 \\
\hline P-J-T-4 & 5.00 & 5.00 & 324.27 & 324.28 & 11.07 & 13.6 & 13.7 & 2.61 & 1.04 \\
\hline P-J-T-5 & 5.00 & 5.00 & 324.84 & 324.85 & 11.00 & 13.6 & 13.70 & 2.70 & 1.04 \\
\hline P-J-T-6 & 5.00 & 5.00 & 323.71 & 323.72 & 10.58 & 13.2 & 13.3 & 2.71 & 1.04 \\
\hline P-J-T-7 & 5.00 & 5.00 & 324.33 & 324.34 & 10.98 & 13.6 & 13.7 & 2.68 & 1.04 \\
\hline P-J-T-8 & 5.00 & 5.00 & 324.52 & 324.52 & 10.52 & 13.1 & 13.24 & 2.72 & 1.04 \\
\hline P-J-T-9 & 5.00 & 5.00 & 323.75 & 323.76 & 10.69 & 13.3 & 13.4 & 2.73 & 1.04 \\
\hline P-K-T-1 & 5.00 & 5.00 & 324.61 & 324.61 & 10.55 & 13.1 & 13.2 & 2.63 & 1.04 \\
\hline P-K-T-2 & 5.00 & 5.00 & 324.70 & 324.69 & 10.62 & 13.2 & 13.3 & 2.63 & 1.04 \\
\hline P-K-T-3 & 5.00 & 5.00 & 323.93 & 323.93 & 10.35 & 12.9 & 13.0 & 2.64 & 1.04 \\
\hline P-K-T-4 & 5.00 & 5.00 & 324.68 & 324.66 & 11.08 & 13.7 & 13.8 & 2.72 & 1.04 \\
\hline P-K-T-5 & 5.00 & 5.00 & 324.37 & 324.37 & 10.57 & 13.2 & 13.3 & 2.71 & 1.04 \\
\hline P-K-T-6 & 5.00 & 5.00 & 323.94 & 323.93 & 10.54 & 13.2 & 13.3 & 2.73 & 1.04 \\
\hline P-K-T-7 & 5.00 & 5.00 & 325.16 & 325.16 & 11.05 & 13.7 & 13.8 & 2.79 & 1.04 \\
\hline P-K-T-8 & 5.00 & 5.00 & 323.77 & 323.76 & 10.66 & 13.3 & 13.4 & 2.73 & 1.04 \\
\hline P-K-T-9 & 5.00 & 5.00 & 324.08 & 324.08 & 10.92 & 13.7 & 13.8 & 2.83 & 1.03 \\
\hline P-L-T-1 & 5.00 & 5.00 & 325.46 & 325.46 & 10.67 & 13 & 13 & 2.7 & 1.04 \\
\hline P-L-T-2 & 5.00 & 5.00 & 325.05 & 325.04 & 10.69 & 13 & 13 & 2.7 & 1.0 \\
\hline P-L-T-3 & 5.00 & 5.00 & 324.68 & 324.67 & 10.64 & 13 & 13 & 2.7 & 1.0 \\
\hline P-L-T-4 & 5.00 & 5.00 & 324.71 & 324.69 & 11.03 & 14 & 13.8 & 2.8 & 1.04 \\
\hline P-L-T-5 & 5.00 & 5.00 & 324.87 & 324.86 & 11.27 & 14 & 14.0 & 2.7 & 1.04 \\
\hline P-L-T-6 & 5.00 & 5.00 & 324.37 & 324.35 & 10.33 & 13 & 13.0 & 2.7 & 1.03 \\
\hline P-L-T-7 & 5.00 & 5.00 & 324.79 & 324.79 & 11.00 & 14 & 13.7 & 2.7 & 1.03 \\
\hline P-L-T-8 & 5.00 & 5.00 & 325.42 & 325.40 & 10.89 & 14 & 13.8 & 2.9 & 1.04 \\
\hline P-L-T-9 & 5.00 & 5.00 & 325.23 & 325.22 & 10.99 & 14 & 13.8 & 2.8 & 1.04 \\
\hline
\end{tabular}




\section{APPENDIX C. RESULTS OF ANALYSES OF MINOR ELEMENTS}

Table C-1. Concentrations of $\mathrm{Li}, \mathrm{Mg}, \mathrm{Ca}, \mathrm{Ti}, \mathrm{Cr}, \mathrm{Mn}, \mathrm{Fe}, \mathrm{Ni}, \mathrm{Zr}, \mathrm{Mo}, \mathrm{Cd}, \mathrm{Sn}, \mathrm{Ba}, \mathrm{La}$, and $\mathrm{Pb}$ in Water Used in PATs. Concentrations listed as upper limits are lower than the LOQ.

(a)

\begin{tabular}{|c|c|c|c|c|c|c|}
\hline Designation & $\begin{array}{r}\mathrm{Li} \\
\mu \mathrm{g} / \mathrm{L} \\
\end{array}$ & $\begin{array}{r}\mathrm{Mg} \\
\mu \mathrm{g} / \mathrm{L}\end{array}$ & $\begin{array}{c}\mathrm{Ca} \\
\mu \mathrm{g} / \mathrm{L} \\
\end{array}$ & $\begin{array}{c}\mathrm{Ti} \\
\mu \mathrm{g} / \mathrm{L} \\
\end{array}$ & $\begin{array}{r}\mathrm{Cr} \\
\mu \mathrm{g} / \mathrm{L} \\
\end{array}$ & $\begin{array}{r}\mathrm{Mn} \\
\mu \mathrm{g} / \mathrm{L} \\
\end{array}$ \\
\hline water $(8 / 11 / 97)$ & $<10$ & $<0.5$ & $<100$ & $<0.1$ & $<0.1$ & $<0.2$ \\
\hline water $(8 / 26 / 97)$ & $<30$ & $<0.7$ & $<40$ & $<0.1$ & $<0.3$ & 0.313 \\
\hline water $(9 / 8 / 97)$ & $<4$ & $<0.9$ & $<500$ & $<0.1$ & $<0.2$ & $<0.3$ \\
\hline
\end{tabular}

(b)

\begin{tabular}{|c|c|c|c|c|c|c|}
\hline Designation & $\begin{array}{c}\mathrm{Fe} \\
\mu \mathrm{g} / \mathrm{L}\end{array}$ & $\begin{array}{c}\mathrm{Ni} \\
\mu \mathrm{g} / \mathrm{L}\end{array}$ & $\begin{array}{c}\mathrm{Zr} \\
\mu \mathrm{g} / \mathrm{L} \\
\end{array}$ & $\begin{array}{c}\text { Mo } \\
\mu \mathrm{g} / \mathrm{L}\end{array}$ & $\begin{array}{c}\mathrm{Cd} \\
\mu \mathrm{g} / \mathrm{L}\end{array}$ & $\begin{array}{c}\mathrm{Sn} \\
\mu \mathrm{g} / \mathrm{L}\end{array}$ \\
\hline water $(8 / 11 / 97)$ & $<30$ & $<3$ & $<0.04$ & $<0.2$ & $<0.3$ & $<0.05$ \\
\hline water $(8 / 26 / 97)$ & $<30$ & $<3$ & $<0.04$ & $<0.1$ & $<0.3$ & $<0.08$ \\
\hline water $(9 / 8 / 97)$ & $<30$ & $<3$ & $<0.04$ & $<0.1$ & $<0.3$ & $<0.08$ \\
\hline
\end{tabular}

(c)

\begin{tabular}{lccc}
\hline Designation & $\mathrm{Ba}$ & $\mathrm{La}$ & $\mathrm{Pb}$ \\
& $\mu \mathrm{g} / \mathrm{L}$ & $\mu \mathrm{g} / \mathrm{L}$ & $\mu \mathrm{g} / \mathrm{L}$ \\
\hline & & & \\
water $(8 / 11 / 97)$ & $<0.05$ & $<0.03$ & $<0.07$ \\
water (8/26/97) & 0.15 & $<0.04$ & $<0.1$ \\
water (9/8/97) & $<0.04$ & $<0.02$ & 0.01 \\
& & & \\
\hline
\end{tabular}


Table C-2. Final Concentrations of $\mathrm{Li}, \mathrm{Mg}, \mathrm{Ca}, \mathrm{Ti}, \mathrm{Cr}$, and $\mathrm{Mn}$ in Leachates from Experimental Blanks. Means, sample standard deviations, and relative standard deviations are calculated for three sets of triplicate tests and illustrated in bold type.

\begin{tabular}{|c|c|c|c|c|c|c|c|c|c|c|}
\hline Designation & $\begin{array}{l}\text { temp. } \\
{\left[{ }^{\circ} \mathrm{C}\right]}\end{array}$ & $\begin{array}{c}\text { water mass } \\
{[\mathrm{g}]}\end{array}$ & $\begin{array}{c}\text { duration } \\
\text { [d] }\end{array}$ & & $\begin{array}{c}\mathrm{Li} \\
\mu \mathrm{g} / \mathrm{L} \\
\end{array}$ & $\begin{array}{c}\mathrm{Mg} \\
\mu \mathrm{g} / \mathrm{L}\end{array}$ & $\begin{array}{c}\mathrm{Ca} \\
\mu \mathrm{g} / \mathrm{L} \\
\end{array}$ & $\begin{array}{c}\mathrm{Ti} \\
\mu \mathrm{g} / \mathrm{L}\end{array}$ & $\begin{array}{c}\mathrm{Cr} \\
\mu \mathrm{g} / \mathrm{L}\end{array}$ & $\begin{array}{c}\mathrm{Mn} \\
\mu \mathrm{g} / \mathrm{L}\end{array}$ \\
\hline P-A-B-1 & 20 & 10 & 3 & & $<10$ & 4.65 & $<100$ & $<0.1$ & 0.13 & 455 \\
\hline P-A-B-2 & 20 & 10 & 3 & & $<30$ & 6.97 & $<40$ & 0.17 & 3.97 & 0 \\
\hline$P-A-B-3$ & 20 & 10 & 3 & & $<4$ & 11.22 & $<500$ & 0.14 & 2.57 & 322 \\
\hline P-B-B-1 & 40 & 10 & 3 & & $<10$ & 5.63 & $<100$ & 0.11 & 1.52 & 156 \\
\hline P-B-B-2 & 40 & 10 & 3 & & $<30$ & 6.55 & $<40$ & 0.14 & 0.78 & 211 \\
\hline P-B-B-3 & 40 & 10 & 3 & & $<4$ & 10.21 & $<500$ & 0.19 & 0.39 & 343 \\
\hline P-C-B-1 & 70 & 10 & 3 & & $<10$ & 6.53 & $<100$ & 0.21 & 2.36 & 275 \\
\hline P-C-B-2 & 70 & 10 & 3 & & $<30$ & 8.92 & 70.46 & 0.38 & 1.66 & 584 \\
\hline P-C-B-3 & 70 & 10 & 3 & & $<4$ & 13.65 & $<500$ & 0.19 & 0.48 & 195 \\
\hline P-D-B-1 & 20 & 5 & 3 & & $<10$ & 14.86 & $<100$ & 0.44 & 2.20 & 766 \\
\hline P-D-B-2 & 20 & 5 & 3 & & $<30$ & 19.98 & 61.36 & 0.34 & 64.85 & 1049 \\
\hline P-D-B-3 & 20 & 5 & 3 & & $<4$ & 15.40 & $<500$ & 0.25 & 25.57 & 602 \\
\hline P-E-B-1 & 40 & 5 & 3 & & $<10$ & 10.19 & $<100$ & 0.24 & 0.55 & 328 \\
\hline P-E-B-2 & 40 & 5 & 3 & & $<30$ & 17.71 & 93.08 & 0.42 & 0.32 & 459 \\
\hline P-E-B-3 & 40 & 5 & 3 & & $<4$ & 20.27 & $<500$ & 0.34 & $<0.2$ & 610 \\
\hline P-F-B-I & 70 & 5 & 3 & & $<10$ & 12.88 & $<100$ & 0.33 & 0.47 & 994 \\
\hline P-F-B-2 & 70 & 5 & 3 & & $<30$ & 14.23 & 119.78 & 0.56 & 0.65 & 1485 \\
\hline P-F-B-3 & 70 & 5 & 3 & & $<4$ & 21.66 & $<500$ & 0.31 & 0.36 & 467 \\
\hline P-G-B-1 & 20 & 10 & 7 & & $<10$ & 4.36 & $<100$ & $<0.1$ & 0.42 & 440 \\
\hline P-G-B-2 & 20 & 10 & 7 & & $<30$ & 8.34 & $<40$ & 0.18 & 4.63 & 676 \\
\hline P-G-B-3 & 20 & 10 & 7 & & $<4$ & 11.63 & $<500$ & 0.19 & 0.49 & 370 \\
\hline P-H-B-1 & 40 & 10 & 7 & & $<10$ & 4.45 & $<100$ & $<0.1$ & 0.20 & 440 \\
\hline P-H-B-2 & 40 & 10 & 7 & & $<30$ & 10.21 & $<40$ & 0.24 & 0.51 & 361 \\
\hline P-H-B-3 & 40 & 10 & 7 & & $<4$ & 12.03 & $<500$ & 0.17 & $<0.2$ & 298 \\
\hline P-I-B-I & 70 & 10 & 7 & & $<10$ & 6.08 & $<100$ & 0.20 & 0.17 & 496 \\
\hline P-I-B-2 & 70 & 10 & 7 & & $<30$ & 7.20 & $<40$ & 0.22 & 0.78 & 1416 \\
\hline P-I-B-3 & 70 & 10 & 7 & & $<4$ & 13.56 & $<500$ & 0.22 & 0.50 & 338 \\
\hline P-J-B-1 & 20 & 5 & 7 & & $<10$ & 8.93 & $<100$ & 0.22 & 0.59 & 685 \\
\hline P-J-B-2 & 20 & 5 & 7 & & $<30$ & 14.75 & 50.08 & 0.23 & 43.63 & 1623 \\
\hline P-J-B-3 & 20 & 5 & 7 & & $<4$ & 19.15 & $<500$ & 0.27 & 0.60 & 778 \\
\hline P-K-B-1 & 40 & 5 & 7 & & $<10$ & 11.91 & $<100$ & 0.29 & 0.19 & 682 \\
\hline P-K-B-2 & 40 & 5 & 7 & & $<30$ & 15.67 & 57.46 & 0.32 & 6.09 & 1863 \\
\hline P-K-B-3 & 40 & 5 & 7 & & $<4$ & 21.45 & $<500$ & 0.30 & 0.30 & 507 \\
\hline P-L-B-1 & 70 & 5 & 7 & & $<10$ & 11.26 & $<100$ & 0.27 & 0.53 & 851 \\
\hline P-L-B-2 & 70 & 5 & 7 & & $<30$ & 25.76 & 72.04 & 0.31 & 0.83 & 1743 \\
\hline \multirow[t]{3}{*}{ P-L-B-3 } & 70 & 5 & 7 & & $<4$ & 21.60 & $<500$ & 0.37 & 0.59 & 896 \\
\hline & & & & mean & - & 12.5 & 74.9 & 0.27 & 5.0 & 660 \\
\hline & & & & $\begin{array}{l}\mathrm{s} \\
\% \mathrm{rsd}\end{array}$ & - & $\begin{array}{r}5.7 \\
45.3\end{array}$ & $\begin{array}{l}24.1 \\
32.1\end{array}$ & $\begin{array}{l}0.10 \\
36.8\end{array}$ & $\begin{array}{c}13.5 \\
270.2\end{array}$ & $\begin{array}{l}461 \\
69.9\end{array}$ \\
\hline
\end{tabular}


Table $\mathrm{C}-2$, contd. Final Concentrations of $\mathrm{Fe}, \mathrm{Ni}, \mathrm{Zr}, \mathrm{Mo}, \mathrm{Cd}$, and $\mathrm{Sn}$ in Leachates from Experimental Blanks. Means, sample standard deviations, and relative standard deviations are calculated for three sets of triplicate tests and illustrated in bold type.

\begin{tabular}{|c|c|c|c|c|c|c|c|c|c|c|}
\hline Designation & $\begin{array}{l}\text { temp. } \\
{\left[{ }^{\circ} \mathrm{C}\right]}\end{array}$ & $\begin{array}{c}\text { water mass } \\
{[\mathrm{g}]}\end{array}$ & $\begin{array}{c}\text { duration } \\
\text { [d] }\end{array}$ & & $\begin{array}{c}\mathrm{Fe} \\
\mu \mathrm{g} / \mathrm{L}\end{array}$ & $\begin{array}{c}\mathrm{Ni} \\
\mu \mathrm{g} / \mathrm{L}\end{array}$ & $\begin{array}{c}\mathrm{Zr} \\
\mu \mathrm{g} / \mathrm{L}\end{array}$ & $\begin{array}{r}\mathrm{Mo} \\
\mu \mathrm{g} / \mathrm{L}\end{array}$ & $\begin{array}{c}\mathrm{Cd} \\
\mu \mathrm{g} / \mathrm{L}\end{array}$ & $\begin{array}{c}\begin{array}{c}\mathrm{Sn} \\
\mu \mathrm{g} / \mathrm{L}\end{array} \\
\end{array}$ \\
\hline P-A-B-1 & 20 & 10 & 3 & & $<30$ & 11.8 & $<0.04$ & $<0.2$ & $<0.3$ & $<0.05$ \\
\hline $\begin{array}{l}\text { P-A-B-2 } \\
\text { P-A-B-3 }\end{array}$ & $\begin{array}{l}20 \\
20\end{array}$ & $\begin{array}{l}10 \\
10\end{array}$ & $\begin{array}{l}3 \\
3\end{array}$ & & $\begin{array}{l}77 \\
77\end{array}$ & $\begin{array}{l}22.9 \\
77.2\end{array}$ & $\begin{array}{l}<0.04 \\
<0.04\end{array}$ & $\begin{array}{l}<0.1 \\
<0.1\end{array}$ & $\begin{array}{l}<0.3 \\
<0.3\end{array}$ & $\begin{array}{l}<0.08 \\
<0.04\end{array}$ \\
\hline $\begin{array}{l}\text { P-B-B-1 } \\
\text { P-B-B-2 }\end{array}$ & $\begin{array}{l}40 \\
40\end{array}$ & $\begin{array}{l}10 \\
10\end{array}$ & $\begin{array}{l}3 \\
3\end{array}$ & & $\begin{array}{l}<30 \\
<30\end{array}$ & $\begin{array}{c}7.0 \\
25.6\end{array}$ & $\begin{array}{l}<0.04 \\
<0.04\end{array}$ & $\begin{array}{l}<0.2 \\
<0.1\end{array}$ & $\begin{array}{l}<0.3 \\
<0.3\end{array}$ & $\begin{array}{l}0.06 \\
0.21\end{array}$ \\
\hline $\begin{array}{l}\text { P-B-B-3 } \\
\text { P-C-B-1 }\end{array}$ & $\begin{array}{l}40 \\
70\end{array}$ & $\begin{array}{l}10 \\
10\end{array}$ & $\begin{array}{l}3 \\
3\end{array}$ & & $\begin{array}{l}<30 \\
<30\end{array}$ & $\begin{array}{l}42.5 \\
27.3\end{array}$ & $\begin{array}{l}<0.04 \\
0.07\end{array}$ & $\begin{array}{l}<0.1 \\
<0.2\end{array}$ & $\begin{array}{l}<0.3 \\
<0.3\end{array}$ & $\begin{array}{l}<0.04 \\
<0.05\end{array}$ \\
\hline $\begin{array}{l}\text { P-C-B-2 } \\
\text { P-C-B-3 }\end{array}$ & $\begin{array}{l}70 \\
70\end{array}$ & $\begin{array}{l}10 \\
10\end{array}$ & $\begin{array}{l}3 \\
3\end{array}$ & & $\begin{array}{l}<30 \\
<30\end{array}$ & $\begin{array}{l}41.5 \\
29.9\end{array}$ & $\begin{array}{l}<0.04 \\
<0.04\end{array}$ & $\begin{array}{l}<0.1 \\
<0.1\end{array}$ & $\begin{array}{l}<0.3 \\
<0.3\end{array}$ & $\begin{array}{l}<0.08 \\
<0.04\end{array}$ \\
\hline $\begin{array}{l}\text { P-D-B-1 } \\
\text { P-D-B-2 }\end{array}$ & $\begin{array}{l}20 \\
20\end{array}$ & $\begin{array}{l}5 \\
5\end{array}$ & $\begin{array}{l}3 \\
3\end{array}$ & & $\begin{array}{l}<30 \\
226\end{array}$ & $\begin{array}{c}30 \\
77.4\end{array}$ & $\begin{array}{l}<0.04 \\
<0.04\end{array}$ & $\begin{array}{l}<0.2 \\
<0.1\end{array}$ & $\begin{array}{c}<0.3 \\
2.1\end{array}$ & $\begin{array}{l}<0.05 \\
0.12\end{array}$ \\
\hline $\begin{array}{l}\text { P-D-B-3 } \\
\text { P-E-B-1 }\end{array}$ & $\begin{array}{l}20 \\
40\end{array}$ & $\begin{array}{l}5 \\
5\end{array}$ & $\begin{array}{l}3 \\
3\end{array}$ & & $\begin{array}{l}153 \\
<30\end{array}$ & $\begin{array}{c}103.0 \\
5\end{array}$ & $\begin{array}{l}<0.04 \\
<0.04\end{array}$ & $\begin{array}{l}<0.1 \\
<0.2\end{array}$ & $\begin{array}{l}<0.3 \\
<0.3\end{array}$ & $\begin{array}{l}<0.04 \\
<0.05\end{array}$ \\
\hline $\begin{array}{l}\text { P-E-B-2 } \\
\text { P-E-B-3 }\end{array}$ & $\begin{array}{l}40 \\
40\end{array}$ & $\begin{array}{l}5 \\
5\end{array}$ & $\begin{array}{l}3 \\
3\end{array}$ & & $\begin{array}{l}<30 \\
<30\end{array}$ & $\begin{array}{l}50.6 \\
70.7\end{array}$ & $\begin{array}{l}<0.04 \\
<0.04\end{array}$ & $\begin{array}{c}<0.1 \\
0.1\end{array}$ & $\begin{array}{l}<0.3 \\
<0.3\end{array}$ & $\begin{array}{l}<0.08 \\
<0.04\end{array}$ \\
\hline P-F-B-1 & 70 & 5 & 3 & & $<30$ & 29 & $<0.04$ & 0.4 & $<0.3$ & $\begin{array}{l}0.07 \\
<008\end{array}$ \\
\hline P-F-B-2 & 70 & 5 & 3 & & 71 & 72.0 & $<0.04$ & $<0.1$ & $<0.3$ & $<0.08$ \\
\hline $\begin{array}{l}\text { P-F-B-3 } \\
\text { P-G-B-1 }\end{array}$ & $\begin{array}{l}70 \\
20\end{array}$ & $\begin{array}{c}5 \\
10\end{array}$ & $\begin{array}{l}3 \\
7\end{array}$ & & $\begin{array}{l}<30 \\
<30\end{array}$ & $\begin{array}{c}38.0 \\
7.4\end{array}$ & $\begin{array}{l}<0.04 \\
<0.04\end{array}$ & $\begin{array}{l}<0.1 \\
<0.2\end{array}$ & $\begin{array}{l}<0.3 \\
<0.3\end{array}$ & $\begin{array}{l}<0.04 \\
<0.05\end{array}$ \\
\hline P-G-B-2 & 20 & 10 & 7 & & 44 & 33.0 & $<0.04$ & $<0.1$ & 1.9 & $<0.08$ \\
\hline P-G-B-3 & 20 & 10 & 7 & & $<30$ & 21.1 & $<0.04$ & $<0.1$ & $<0.3$ & $<0.04$ \\
\hline $\begin{array}{l}\text { P-H-B-1 } \\
\text { P-H-B-2 }\end{array}$ & $\begin{array}{l}40 \\
40\end{array}$ & $\begin{array}{l}10 \\
10\end{array}$ & $\begin{array}{l}7 \\
7\end{array}$ & & $\begin{array}{l}<30 \\
<30\end{array}$ & $\begin{array}{c}7.9 \\
22.4\end{array}$ & $\begin{array}{l}<0.04 \\
<0.04\end{array}$ & $\begin{array}{l}0.2 \\
0.1\end{array}$ & $\begin{array}{l}<0.3 \\
<0.3\end{array}$ & $\begin{array}{l}<0.05 \\
0.06\end{array}$ \\
\hline P-H-B-3 & 40 & 10 & 7 & & $<30$ & 19.7 & $<0.04$ & $<0.1$ & $<0.3$ & $<0.04$ \\
\hline P-I-B-1 & 70 & 10 & 7 & & $<30$ & 17.8 & 0.09 & 0.7 & $<0.3$ & $<0.05$ \\
\hline P-I-B-2 & 70 & 10 & 7 & & $<30$ & 51.4 & $<0.04$ & $<0.1$ & $<0.3$ & $<0.08$ \\
\hline P-1-B-3 & 70 & 10 & 7 & & $<30$ & 21.5 & $<0.04$ & $<0.1$ & $<0.3$ & $<0.04$ \\
\hline P-J-B-1 & 20 & 5 & 7 & & $<30$ & 11 & $<0.04$ & $<0.2$ & $<0.3$ & $<0.05$ \\
\hline P-J-B-2 & 20 & 5 & 7 & & 108 & 112.7 & $<0.04$ & $<0.1$ & 1.7 & $<0.08$ \\
\hline P-J-B-3 & 20 & 5 & 7 & & 110 & 136.0 & $<0.04$ & $<0.1$ & $<0.3$ & $<0.04$ \\
\hline P-K-B-1 & 40 & 5 & 7 & & $<30$ & 6.4 & $<0.04$ & $<0.2$ & $<0.3$ & 0.11 \\
\hline P-K-B-2 & 40 & 5 & 7 & & $<30$ & 79.0 & $<0.04$ & $<0.1$ & $<0.3$ & $<0.08$ \\
\hline P-K-B-3 & 40 & 5 & 7 & & $<30$ & 73.6 & $<0.04$ & $<0.1$ & $<0.3$ & $<0.04$ \\
\hline P-L-B-1 & 70 & 5 & 7 & & $<30$ & 21 & $<0.04$ & $<0.2$ & $<0.3$ & 0.05 \\
\hline P-L-B-2 & 70 & 5 & 7 & & $<30$ & 51.5 & $<0.04$ & 0.7 & $<0.3$ & $<0.08$ \\
\hline \multirow[t]{4}{*}{ P-L-B-3 } & 70 & 5 & 7 & & 63 & 63.3 & $<0.04$ & $<0.1$ & $<0.3$ & $<0.04$ \\
\hline & & & & mean & 103 & 42 & 0.1 & 0.4 & 1.9 & 0.1 \\
\hline & & & & & 56 & 33 & 0.01 & 0.3 & 0.2 & 0.06 \\
\hline & & & & $\%$ rsd & 54 & 77 & 14.6 & 70.7 & 10.4 & 57.2 \\
\hline
\end{tabular}


Table $\mathrm{C}-2$, contd. Final Concentrations of $\mathrm{Ba}, \mathrm{La}$, and $\mathrm{Pb}$ in Leachates from Experimental Blanks. Means, sample standard deviations, and relative standard deviations are calculated for three sets of triplicate tests and illustrated in bold type.

\begin{tabular}{|c|c|c|c|c|c|c|c|}
\hline Designation & $\begin{array}{l}\text { temp. } \\
{\left[{ }^{\circ} \mathrm{C}\right]}\end{array}$ & $\begin{array}{c}\text { water mass } \\
{[\mathrm{g}]}\end{array}$ & $\begin{array}{c}\text { duration } \\
\text { [d] }\end{array}$ & & $\begin{array}{c}\mathrm{Ba} \\
\mu \mathrm{g} / \mathrm{L} \\
\end{array}$ & $\begin{array}{c}\mathrm{La} \\
\mu \mathrm{g} / \mathrm{L} \\
\end{array}$ & $\begin{array}{c}\mathrm{Pb} \\
\mu \mathrm{g} / \mathrm{L} \\
\end{array}$ \\
\hline P-A-B-1 & 20 & 10 & 3 & & 0.07 & $<0.03$ & $<0.07$ \\
\hline P-A-B-2 & 20 & 10 & 3 & & 0.20 & $<0.04$ & 0.23 \\
\hline P-A-B-3 & 20 & 10 & 3 & & 0.41 & $<0.02$ & 0.24 \\
\hline P-B-B-1 & 40 & 10 & 3 & & 0.12 & $<0.03$ & $<0.07$ \\
\hline P-B-B-2 & 40 & 10 & 3 & & 0.17 & $<0.04$ & 0.11 \\
\hline P-B-B-3 & 40 & 10 & 3 & & 0.25 & $<0.02$ & 0.09 \\
\hline P-C-B-1 & 70 & 10 & 3 & & 0.31 & $<0.03$ & 0.17 \\
\hline P-C-B-2 & 70 & 10 & 3 & & 0.44 & $<0.04$ & 0.36 \\
\hline P-C-B-3, & 70 & 10 & 3 & & 0.38 & $<0.02$ & 0.96 \\
\hline P-D-B-I & 20 & 5 & 3 & & 0.15 & 0.03 & 0.18 \\
\hline P-D-B-2 & 20 & 5 & 3 & & 0.18 & $<0.04$ & 5.60 \\
\hline P-D-B-3 & 20 & 5 & 3 & & 0.21 & $<0.02$ & 0.09 \\
\hline P-E-B-1 & 40 & 5 & 3 & & 0.13 & $<0.03$ & $<0.07$ \\
\hline P-E-B-2 & 40 & 5 & 3 & & 0.33 & $<0.04$ & 0.44 \\
\hline P-E-B-3 & 40 & 5 & 3 & & 0.23 & $<0.02$ & 0.20 \\
\hline P-F-B-1 & 70 & 5 & 3 & & 0.14 & $<0.03$ & $<0.07$ \\
\hline P-F-B-2 & 70 & 5 & 3 & & 0.36 & $<0.04$ & $<0.1$ \\
\hline P-F-B-3 & 70 & 5 & 3 & & 0.25 & $<0.02$ & 0.29 \\
\hline P-G-B-1 & 20 & 10 & 7 & & 0.10 & $<0.03$ & $<0.07$ \\
\hline P-G-B-2 & 20 & 10 & 7 & & 0.23 & $<0.04$ & $<0.1$ \\
\hline P-G-B-3 & 20 & 10 & 7 & & 0.25 & $<0.02$ & 0.19 \\
\hline P-H-B-1 & 40 & 10 & 7 & & 0.12 & $<0.03$ & $<0.07$ \\
\hline P-H-B-2 & 40 & 10 & 7 & & 0.16 & 0.10 & $<0.1$ \\
\hline P-H-B-3 & 40 & 10 & 7 & & 0.25 & $<0.02$ & 0.09 \\
\hline P-I-B-1 & 70 & 10 & 7 & & 0.20 & $<0.03$ & 0.23 \\
\hline P-I-B-2 & 70 & 10 & 7 & & 0.31 & $<0.04$ & $<0.1$ \\
\hline P-I-B-3 & 70 & 10 & 7 & & 0.37 & $<0.02$ & 0.29 \\
\hline P-J-B-1 & 20 & 5 & 7 & & 0.13 & 0.12 & 0.26 \\
\hline P-J-B-2 & 20 & 5 & 7 & & 0.16 & $<0.04$ & 0.28 \\
\hline P-J-B-3 & 20 & 5 & 7 & & 0.20 & $<0.02$ & 0.19 \\
\hline P-K-B-1 & 40 & 5 & 7 & & 0.39 & $<0.03$ & 0.10 \\
\hline P-K-B-2 & 40 & 5 & 7 & & 0.26 & $<0.04$ & 0.11 \\
\hline P-K-B-3 & 40 & 5 & 7 & & 0.35 & $<0.02$ & 0.15 \\
\hline P-L-B-1 & 70 & 5 & 7 & & 0.25 & $<0.03$ & 0.36 \\
\hline P-L-B-2 & 70 & 5 & 7 & & 0.27 & $<0.04$ & $<0.1$ \\
\hline \multirow[t]{4}{*}{ P-L-B-3 } & 70 & 5 & 7 & & 0.25 & $<0.02$ & 0.12 \\
\hline & & & & mean & 0.2 & 0.1 & 0.5 \\
\hline & & & & & 0.1 & 0.04 & 1.1 \\
\hline & & & & $\%$ rsd & 40.1 & 53.2 & 239.6 \\
\hline
\end{tabular}


Table C-3. Final Concentrations of $\mathrm{Li}, \mathrm{Mg}, \mathrm{Ca}, \mathrm{Ti}, \mathrm{Cr}$, and $\mathrm{Mn}$ in Leachates from 3-day, 1:10 Tests. Means, sample standard deviations, and relative standard deviations are calculated for three sets of triplicate tests and illustrated in bold type.

\begin{tabular}{|c|c|c|c|c|c|c|c|c|c|c|}
\hline Designation & $\begin{array}{l}\text { temp. } \\
{\left[{ }^{\circ} \mathrm{C}\right]}\end{array}$ & $\begin{array}{c}\text { glass/water } \\
{[\mathrm{g} / \mathrm{g}]}\end{array}$ & $\begin{array}{c}\text { duration } \\
\text { [d] }\end{array}$ & & $\begin{array}{c}\mathrm{Li} \\
\mu \mathrm{g} / \mathrm{L}\end{array}$ & $\begin{array}{c}\mathrm{Mg} \\
\mu \mathrm{g} / \mathrm{L}\end{array}$ & $\begin{array}{c}\mathrm{Ca} \\
\mu \mathrm{g} / \mathrm{L} \\
\end{array}$ & $\begin{array}{c}\mathrm{Ti} \\
\mu \mathrm{g} / \mathrm{L} \\
\end{array}$ & $\begin{array}{c}\mathrm{Cr} \\
\mu \mathrm{g} / \mathrm{L} \\
\end{array}$ & $\begin{array}{c}\mathrm{Mn} \\
\mu \mathrm{g} / \mathrm{L}\end{array}$ \\
\hline P-A-T-1 & 20 & $1: 10$ & 3 & & $<70$ & 4.8 & $<80$ & 1.0 & 3.3 & 12 \\
\hline P-A-T-2 & 20 & $1: 10$ & 3 & & $<70$ & 7.1 & $<80$ & 1.0 & 2.5 & 6 \\
\hline P-A-T-3 & 20 & 1:10 & 3 & & $<70$ & 6.5 & $<80$ & 0.9 & 3.1 & 20 \\
\hline P-A-T-4 & 20 & $1: 10$ & 3 & & 39.3 & 3.9 & $<100$ & 0.6 & 14.5 & 86 \\
\hline P-A-T-5 & 20 & 1:10 & 3 & & 27.8 & 3.3 & $<100$ & $<0.4$ & 7.5 & 90 \\
\hline P-A-T-6 & 20 & $1: 10$ & 3 & & 21.5 & 5.9 & $<100$ & $<0.4$ & 12.6 & 108 \\
\hline P-A-T-7 & 20 & 1:10 & 3 & & $<20$ & 4.6 & $<100$ & 0.5 & 39.1 & 24 \\
\hline P-A-T-8 & 20 & $1: 10$ & 3 & & $<20$ & 35.1 & $<100$ & 1.4 & 2.0 & 92 \\
\hline \multirow[t]{4}{*}{ P-A-T-9 } & 20 & $1: 10$ & 3 & & $<20$ & 26.1 & $<100$ & 1.3 & 6.6 & 74 \\
\hline & & & & mean & 29.5 & 10.8 & - & 0.95 & 10.1 & 57 \\
\hline & & & & & 9.0 & 11.5 & - & 0.31 & 11.7 & 41 \\
\hline & & & & $\%$ rsd & 30.5 & 106.2 & - & 32.93 & 116.1 & 71 \\
\hline P-B-T-1 & 40 & 1:10 & 3 & & $<60$ & 4.1 & $<80$ & 1.7 & 9.1 & 36 \\
\hline P-B-T-2 & 40 & $1: 10$ & 3 & & $<60$ & 3.7 & $<80$ & 1.5 & 8.1 & 48 \\
\hline P-B-T-3 & 40 & 1:10 & 3 & & $<60$ & 6.1 & $<80$ & 1.6 & 10.5 & 39 \\
\hline P-B-T-4 & 40 & $1: 10$ & 3 & & 46.2 & 3.7 & $<100$ & 0.6 & 13.1 & 31 \\
\hline P-B-T-5 & 40 & 1:10 & 3 & & 19.1 & 2.3 & $<100$ & 0.7 & 11.5 & 7 \\
\hline P-B-T-6 & 40 & 1:10 & 3 & & 13.7 & 4.8 & $<100$ & 0.8 & 7.8 & 15 \\
\hline P-B-T-7 & 40 & $1: 10$ & 3 & & $<20$ & 5.7 & $<100$ & 2.2 & 27.6 & 33 \\
\hline P-B-T-8 & 40 & $1: 10$ & 3 & & $<20$ & 4.1 & $<100$ & 0.8 & 43.0 & 19 \\
\hline \multirow[t]{4}{*}{ P-B-T-9 } & 40 & 1:10 & 3 & & $<20$ & 6.3 & $<100$ & 0.8 & 7.8 & 21 \\
\hline & & & & mean & 26.3 & 4.5 & - & 1.2 & 15.4 & 28 \\
\hline & & & & & 17.4 & 1.3 & - & 0.5 & 12.1 & 13 \\
\hline & & & & $\%$ rsd & 66.2 & 28.8 & - & 46.1 & 78.3 & 47 \\
\hline P-C-T-1 & 70 & $1: 10$ & 3 & & $<70$ & 6.9 & 286 & 24.5 & 52.7 & 29 \\
\hline P-C-T-2 & 70 & $1: 10$ & 3 & & $<70$ & 8.9 & 291 & 25.4 & 54.0 & 54 \\
\hline P-C-T-3 & 70 & $1: 10$ & 3 & & $<70$ & 6.3 & 278 & 27.4 & 55.9 & 78 \\
\hline P-C-T-4 & 70 & $1: 10$ & 3 & & $<10$ & 8.6 & 172 & 17.7 & 43.3 & 37 \\
\hline P-C-T-5 & 70 & $1: 10$ & 3 & & $<10$ & 4.8 & 149 & 17.4 & 46.8 & 17 \\
\hline P-C-T-6 & 70 & $1: 10$ & 3 & & $<10$ & 6.2 & 170 & 20.0 & 63.0 & 29 \\
\hline P-C-T-7 & 70 & $1: 10$ & 3 & & $<20$ & 10.7 & 404 & 24.1 & 57.4 & 116 \\
\hline P-C-T-8 & 70 & $1: 10$ & 3 & & $<20$ & 8.9 & 393 & 24.7 & 51.2 & 13 \\
\hline \multirow[t]{4}{*}{ P-C-T-9 } & 70 & $1: 10$ & 3 & & $<20$ & 24.6 & 482 & 26.4 & 54.5 & 18 \\
\hline & & - & & mean & - & 9.5 & 292 & 23.1 & 53.2 & 43 \\
\hline & & & & & - & 5.9 & 117 & 3.7 & 5.8 & 34 \\
\hline & & & & $\%$ rsd & - & 62.0 & 40 & 16.2 & 10.9 & 79 \\
\hline
\end{tabular}


Table C-3, contd. Final Concentrations of $\mathrm{Fe}, \mathrm{Ni}, \mathrm{Zr}, \mathrm{Mo}, \mathrm{Cd}$, and $\mathrm{Sn}$ in Leachates from 3-day, 1:10 Tests. Means, sample standard deviations, and relative standard deviations are calculated for three sets of triplicate tests and illustrated in bold type.

\begin{tabular}{|c|c|c|c|c|c|c|c|c|c|c|}
\hline Designation & $\begin{array}{l}\text { temp. } \\
{\left[{ }^{\circ} \mathrm{C}\right]}\end{array}$ & $\begin{array}{c}\text { glass/water } \\
{[\mathrm{g} / \mathrm{g}]}\end{array}$ & $\begin{array}{c}\text { duration } \\
\text { [d] }\end{array}$ & & $\begin{array}{c}\mathrm{Fe} \\
\mu \mathrm{g} / \mathrm{L}\end{array}$ & $\begin{array}{c}\mathrm{Ni} \\
\mu \mathrm{g} / \mathrm{L} \\
\end{array}$ & $\begin{array}{c}\mathrm{Zr} \\
\mu \mathrm{g} / \mathrm{L} \\
\end{array}$ & $\begin{array}{r}\text { Mo } \\
\mu \mathrm{g} / \mathrm{L} \\
\end{array}$ & $\begin{array}{r}\text { Cd } \\
\mu \mathrm{g} / \mathrm{L}\end{array}$ & $\begin{array}{c}\mathrm{Sn} \\
\mu \mathrm{g} / \mathrm{L}\end{array}$ \\
\hline P-A-T-I & 20 & $1: 10$ & 3 & & $<70$ & $<3$ & $<0.3$ & 2.1 & $<0.3$ & 0.34 \\
\hline P-A-T-2 & 20 & $1: 10$ & 3 & & $<70$ & $<3$ & $<0.3$ & 2.0 & $<0.3$ & 0.24 \\
\hline P-A-T-3 & 20 & $1: 10$ & 3 & & $<70$ & $<3$ & 0.59 & 3.8 & $<0.3$ & 0.48 \\
\hline P-A-T-4 & 20 & $1: 10$ & 3 & & 51 & 16.5 & 0.17 & 9.3 & $<0.6$ & 0.51 \\
\hline P-A-T-5 & 20 & $1: 10$ & 3 & & $<40$ & 14.6 & $<0.1$ & 12.0 & $<0.6$ & $<0.2$ \\
\hline P-A-T-6 & 20 & $1: 10$ & 3 & & 54 & 13.4 & 0.11 & 7.9 & $<0.6$ & 0.25 \\
\hline P-A-T-7 & 20 & $1: 10$ & 3 & & 107 & 15.8 & 0.62 & 13.1 & 0.4 & 0.28 \\
\hline P-A-T-8 & 20 & $1: 10$ & 3 & & $<20$ & 18.0 & 0.13 & 14.7 & 26.5 & 8.54 \\
\hline \multirow[t]{4}{*}{ P-A-T-9 } & 20 & $1: 10$ & 3 & & 47 & 21.9 & 0.23 & 20.1 & 45.3 & 9.72 \\
\hline & & & & mean & 65 & 16.7 & 0.3 & 9.5 & 24.1 & 2.5 \\
\hline & & & & & 29 & 3.0 & 0.2 & 6.2 & 22.6 & 4.1 \\
\hline & & & & $\%$ rsd & 44 & 18.1 & 76.3 & 65.3 & 93.7 & 160.2 \\
\hline P-B-T-1 & 40 & $1: 10$ & 3 & & $<70$ & $<3$ & 1.45 & 20.1 & 0.5 & 3.64 \\
\hline P-B-T-2 & 40 & $1: 10$ & 3 & & $<70$ & $<3$ & 1.21 & 25.2 & 0.4 & 3.67 \\
\hline P-B-T-3 & 40 & $1: 10$ & 3 & & $<70$ & $<3$ & 1.32 & 17.9 & $<0.3$ & 4.31 \\
\hline P-B-T-4 & 40 & $1: 10$ & 3 & & $<40$ & $<4$ & 0.72 & 26.7 & 0.4 & 2.24 \\
\hline P-B-T-5 & 40 & $1: 10$ & 3 & & $<40$ & $<4$ & 0.71 & 29.5 & 0.4 & 2.21 \\
\hline P-B-T-6 & 40 & $1: 10$ & 3 & & $<40$ & $<4$ & 1.07 & 28.3 & 0.4 & 2.76 \\
\hline P-B-T-7 & 40 & $1: 10$ & 3 & & 150 & 18.0 & 1.30 & 32.3 & 0.8 & 2.13 \\
\hline P-B-T-8 & 40 & $1: 10$ & 3 & & 60 & 14.7 & 0.77 & 42.5 & 0.9 & 1.03 \\
\hline \multirow[t]{4}{*}{ P-B-T-9 } & 40 & $1: 10$ & 3 & & 40 & 8.94 & 0.72 & 16.0 & 0.4 & 4.54 \\
\hline & & & & mean & 83 & 13.9 & 1.0 & 26.5 & 0.5 & 2.9 \\
\hline & & & & & 58 & 4.6 & 0.3 & 8.1 & 0.2 & 1.2 \\
\hline & & & & $\%$ rsd & 70 & 33.0 & 29.2 & 30.7 & 35.2 & 39.4 \\
\hline P-C-T-1 & 70 & $1: 10$ & 3 & & 284 & 13.6 & 201 & 78.6 & 14.3 & 32.9 \\
\hline P-C-T-2 & 70 & $1: 10$ & 3 & & 273 & 12.1 & 209 & 77.4 & 15.0 & 32.5 \\
\hline P-C-T-3 & 70 & $1: 10$ & 3 & & 346 & 14.1 & 209 & 81.8 & 17.7 & 31.9 \\
\hline P-C-T-4 & 70 & $1: 10$ & 3 & & 168 & 12.6 & 178 & 118.3 & 10.7 & 26.7 \\
\hline P-C-T-5 & 70 & $1: 10$ & 3 & & 162 & 11.8 & 173 & 116.2 & 10.2 & 26.9 \\
\hline P-C-T-6 & 70 & $1: 10$ & 3 & & 209 & 14.7 & 200 & 110.1 & 11.2 & 22.7 \\
\hline P-C-T-7 & 70 & $1: 10$ & 3 & & 256 & 42.9 & 187 & 87.1 & 30.5 & 30.5 \\
\hline P-C-T-8 & 70 & $1: 10$ & 3 & & 299 & 19.6 & 204 & 79.5 & 14.6 & 37.0 \\
\hline \multirow[t]{4}{*}{ P-C-T-9 } & 70 & $1: 10$ & 3 & & 307 & 20.9 & 206 & 85.1 & 15.8 & 37.6 \\
\hline & & . & & mean & 256 & 18 & 197 & 93 & 16 & 31 \\
\hline & & & & & 64 & 10 & 14 & 17 & 6 & 5 \\
\hline & & & & $\%$ rsd & 25 & 55 & 7 & 18 & 40 & 16 \\
\hline
\end{tabular}


Table C-3, contd. Final Concentrations of $\mathrm{Ba}, \mathrm{La}$, and $\mathrm{Pb}$ in Leachates from 3-day, 1:10 Tests. Means, sample standard deviations, and relative standard deviations are calculated for three sets of triplicate tests and illustrated in bold type.

\begin{tabular}{|c|c|c|c|c|c|c|c|}
\hline Designation & $\begin{array}{l}\text { temp. } \\
{\left[{ }^{\circ} \mathrm{C}\right]}\end{array}$ & $\begin{array}{c}\text { glass/water } \\
{[\mathrm{g} / \mathrm{g}]}\end{array}$ & $\begin{array}{c}\text { duration } \\
\text { [d] }\end{array}$ & & $\begin{array}{c}\mathrm{Ba} \\
\mu \mathrm{g} / \mathrm{L} \\
\end{array}$ & $\begin{array}{c}\mathrm{La} \\
\mu \mathrm{g} / \mathrm{L} \\
\end{array}$ & $\begin{array}{c}\mathrm{Pb} \\
\mu \mathrm{g} / \mathrm{L}\end{array}$ \\
\hline P-A-T-1 & 20 & $1: 10$ & 3 & & 0.14 & 0.05 & 0.68 \\
\hline P-A-T-2 & 20 & 1:10 & 3 & & 0.27 & $<0.04$ & 0.24 \\
\hline P-A-T-3 & 20 & $1: 10$ & 3 & & 0.11 & 0.04 & 0.23 \\
\hline P-A-T-4 & 20 & $1: 10$ & 3 & & $<0.1$ & $<0.06$ & 1.95 \\
\hline P-A-T-5 & 20 & $1: 10$ & 3 & & $<0.1$ & $<0.06$ & 0.48 \\
\hline P-A-T-6 & 20 & $1: 10$ & 3 & & 0.11 & 0.15 & 23.57 \\
\hline P-A-T-7 & 20 & $1: 10$ & 3 & & $<1$ & 0.22 & 0.57 \\
\hline P-A-T-8 & 20 & 1:10 & 3 & & 1.41 & 0.20 & 72.12 \\
\hline \multirow[t]{4}{*}{ P-A-T-9 } & 20 & 1:10 & 3 & & 1.18 & 0.33 & 122.4 \\
\hline & & & & mean & 0.5 & 0.2 & 24.7 \\
\hline & & & & & 0.6 & 0.1 & 43.7 \\
\hline & & & & $\%$ rsd & 111.2 & 66.6 & 176.8 \\
\hline P-B-T-1 & 40 & $1: 10$ & 3 & & 0.08 & 0.59 & 0.89 \\
\hline P-B-T-2 & 40 & $1: 10$ & 3 & & 0.07 & $<0.04$ & 0.93 \\
\hline P-B-T-3 & 40 & $1: 10$ & 3 & & 0.12 & $<0.04$ & 0.56 \\
\hline P-B-T-4 & 40 & 1:10 & 3 & & 0.11 & $<0.06$ & 1.67 \\
\hline P-B-T-5 & 40 & 1:10 & 3 & & $<0.1$ & $<0.06$ & 0.71 \\
\hline P-B-T-6 & 40 & $1: 10$ & 3 & & 0.12 & $<0.06$ & 0.80 \\
\hline P-B-T-7 & 40 & $1: 10$ & 3 & & $<1$ & 0.04 & 1.77 \\
\hline P-B-T-8 & 40 & $1: 10$ & 3 & & $<1$ & $<0.02$ & 0.37 \\
\hline \multirow[t]{4}{*}{ P-B-T-9 } & 40 & $1: 10$ & 3. & & $<1$ & 0.03 & 0.84 \\
\hline & & & & mean & 0.1 & 0.2 & 0.9 \\
\hline & & & & & 0.0 & 0.3 & 0.5 \\
\hline & & & & $\%$ rsd & 24.1 & 147.5 & 49.6 \\
\hline P-C-T-1 & 70 & $1: 10$ & 3 & & 0.48 & 3.31 & 17.5 \\
\hline P-C-T-2 & 70 & $1: 10$ & 3 & & 0.40 & 3.52 & 18.7 \\
\hline P-C-T-3 & 70 & $1: 10$ & 3 & & 0.49 & 3.55 & 21.2 \\
\hline P-C-T-4 & 70 & $1: 10$ & 3 & & 0.30 & 3.14 & 20.4 \\
\hline P-C-T-5 & 70 & $1: 10$ & 3 & & 0.30 & 3.18 & 15.6 \\
\hline P-C-T-6 & 70 & $1: 10$ & 3 & & 0.34 & 3.72 & 17.0 \\
\hline P-C-T-7 & 70 & $1: 10$ & 3 & & $<1$ & 3.39 & 17.6 \\
\hline P-C-T-8 & 70 & $1: 10$ & 3 & & $<1$ & 3.51 & 18.6 \\
\hline \multirow[t]{4}{*}{ P-C-T-9 } & 70 & $1: 10$ & 3 & & $<1$ & 3.56 & 20.3 \\
\hline & & & & mean & 0.4 & 3.4 & 18.6 \\
\hline & & & & s & 0.1 & 0.2 & 1.9 \\
\hline & & & & $\%$ rsd & 22.4 & 5.6 & 10.0 \\
\hline
\end{tabular}


Table C-4. Final Concentrations of $\mathrm{Li}, \mathrm{Mg}, \mathrm{Ca}, \mathrm{Ti}, \mathrm{Cr}$, and $\mathrm{Mn}$ in Leachates from 3-day, 1:1 Tests. Means, sample standard deviations, and relative standard deviations are calculated for three sets of triplicate tests and illustrated in bold type.

\begin{tabular}{|c|c|c|c|c|c|c|c|c|c|c|}
\hline Designation & $\begin{array}{l}\text { temp. } \\
{\left[{ }^{\circ} \mathrm{C}\right]}\end{array}$ & $\begin{array}{c}\text { glass/water } \\
{[\mathrm{g} / \mathrm{g}]}\end{array}$ & $\begin{array}{c}\text { duration } \\
\text { [d] }\end{array}$ & & $\begin{array}{c}\mathrm{Li} \\
\mu \mathrm{g} / \mathrm{L} \\
\end{array}$ & $\begin{array}{c}\mathrm{Mg} \\
\mu \mathrm{g} / \mathrm{L}\end{array}$ & $\begin{array}{c}\mathrm{Ca} \\
\mu \mathrm{g} / \mathrm{L} \\
\end{array}$ & $\begin{array}{c}\mathrm{Ti} \\
\mu \mathrm{g} / \mathrm{L}\end{array}$ & $\begin{array}{c}\mathrm{Cr} \\
\mu \mathrm{g} / \mathrm{L} \\
\end{array}$ & $\begin{array}{c}\mathrm{Mn} \\
\mu \mathrm{g} / \mathrm{L}\end{array}$ \\
\hline P-D-T-1 & 20 & $1: 1$ & 3 & & $<70$ & 8.8 & 159 & 6.5 & 24.3 & 58 \\
\hline P-D-T-2 & 20 & $1: 1$ & 3 & & $<70$ & 9.0 & 155 & 5.9 & 24.3 & 46 \\
\hline P-D-T-3 & 20 & $1: 1$ & 3 & & $<70$ & 23.8 & 175 & 6.8 & 25.8 & 43 \\
\hline P-D-T-4 & 20 & $1: 1$ & 3 & & $<10$ & 6.6 & $<100$ & 2.2 & 18.2 & 15 \\
\hline P-D-T-5 & 20 & $1: 1$ & 3 & & $<10$ & 8.1 & $<100$ & 2.5 & 23.5 & 31 \\
\hline P-D-T-6 & 20 & $1: 1$ & 3 & & $<10$ & 11.5 & 106 & 1.4 & 21.6 & 43 \\
\hline P-D-T-7 & 20 & $1: 1$ & 3 & & $<20$ & 26.4 & 424 & 3.9 & 28.6 & 42 \\
\hline P-D-T-8 & 20 & $1: 1$ & 3 & & $<20$ & 15.7 & 185 & 2.6 & 25.5 & 41 \\
\hline \multirow[t]{4}{*}{ P-D-T-9 } & 20 & 1:1 & 3 & & $<20$ & 12.1 & 134 & 2.6 & 30.3 & 21 \\
\hline & & & & mean & - & 13.6 & 191 & 3.8 & 24.7 & 38 \\
\hline & & & & & - & 7.1 & 106 & 2.0 & 3.6 & 13 \\
\hline & & & & $\%$ rsd & - & 52.1 & 55.4 & 53.3 & 14.4 & 35 \\
\hline P-E-T-1 & 40 & $1: 1$ & 3 & & $<70$ & 13.0 & 395 & 5.5 & 42.7 & 80 \\
\hline P-E-T-2 & 40 & $1: 1$ & 3 & & $<70$ & 13.9 & 444 & 11.3 & 42.2 & 49 \\
\hline P-E-T-3 & 40 & $1: 1$ & 3 & & $<70$ & 18.5 & 455 & 9.4 & 50.7 & 60 \\
\hline P-E-T-4 & 40 & $1: 1$ & 3 & & $<10$ & 12.2 & 296 & 6.2 & 38.2 & 14 \\
\hline P-E-T-5 & 40 & $1: 1$ & 3 & & $<10$ & 12.4 & 234 & 5.7 & 32.8 & 37 \\
\hline P-E-T-6 & 40 & $1: 1$ & 3 & & $<10$ & 11.8 & 235 & 5.7 & 33.1 & 19 \\
\hline P-E-T-7 & 40 & 1:1 & 3 & & $<20$ & 17.1 & 594 & 7.4 & 35.3 & 24 \\
\hline P-E-T-8 & 40 & $1: 1$ & 3 & & $<20$ & 19.1 & 540 & 6.2 & 40.5 & 47 \\
\hline \multirow[t]{4}{*}{ P-E-T-9 } & 40 & $1: 1$ & 3 & & $<20$ & 24.4 & 602 & 6.6 & 35.8 & 20 \\
\hline & & & & mean & - & 15.8 & 422 & 7.1 & 39.0 & 39 \\
\hline & & & & & - & 4.3 & 143 & 2.0 & 5.7 & 22 \\
\hline & & & & $\%$ rsd & - & 27.0 & 34 & 28.0 & 14.6 & 56 \\
\hline P-F-T-1 & 70 & $1: 1$ & 3 & & $<70$ & 18.5 & 1172 & 26.6 & 86.4 & 20 \\
\hline P-F-T-2 & 70 & $1: 1$ & 3 & & $<70$ & 19.3 & 1157 & 27.5 & 90.0 & 23 \\
\hline P-F-T-3 & 70 & $1: 1$ & 3 & & $<70$ & 16.7 & 1004 & 17.6 & 77.2 & 14 \\
\hline P-F-T-4 & 70 & $1: 1$ & 3 & & $<10$ & 17.4 & 620 & 17.0 & 57.6 & 31 \\
\hline P-F-T-5 & 70 & $1: 1$ & 3 & & $<10$ & 17.8 & 721 & 18.7 & 67.1 & 27 \\
\hline P-F-T-6 & 70 & $1: 1$ & 3 & & $<10$ & 20.5 & 727 & 21.7 & 69.0 & 20 \\
\hline P-F-T-7 & 70 & 1:1 & 3 & & $<20$ & 31.8 & 1545 & 20.6 & 75.8 & 37 \\
\hline P-F-T-8 & 70 & $1: 1$ & 3 & & $<20$ & 34.1 & 1645 & 21.0 & 72.7 & 19 \\
\hline \multirow[t]{4}{*}{ P-F-T-9 } & 70 & $1: 1$ & 3 & & $<20$ & 27.1 & 1445 & 21.3 & 77.1 & 18 \\
\hline & & & & mean & - & 22.6 & 1115 & 21.3 & 74.8 & 23 \\
\hline & & & & & - & 6.7 & 378 & 3.7 & 9.8 & 7 \\
\hline & & & & $\%$ rsd & - & 29.5 & 33.9 & 17.2 & 13.1 & 30 \\
\hline
\end{tabular}


Table C-4, contd. Final Concentrations of $\mathrm{Fe}, \mathrm{Ni}, \mathrm{Zr}, \mathrm{Mo}, \mathrm{Cd}$, and $\mathrm{Sn}$ in Leachates from 3-day, 1:1 Tests. Means, sample standard deviations, and relative standard deviations are calculated for three sets of triplicate tests and illustrated in bold type.

\begin{tabular}{|c|c|c|c|c|c|c|c|c|c|c|}
\hline Designation & $\begin{array}{l}\text { temp. } \\
{\left[{ }^{\circ} \mathrm{C}\right]}\end{array}$ & $\begin{array}{c}\text { glass/water } \\
{[\mathrm{g} / \mathrm{g}]}\end{array}$ & $\begin{array}{c}\text { duration } \\
\text { [d] }\end{array}$ & & $\begin{array}{c}\mathrm{Fe} \\
\mu \mathrm{g} / \mathrm{L}\end{array}$ & $\begin{array}{c}\mathrm{Ni} \\
\mu \mathrm{g} / \mathrm{L}\end{array}$ & $\begin{array}{c}\mathrm{Zr} \\
\mu \mathrm{g} / \mathrm{L} \\
\end{array}$ & $\begin{array}{c}\mathrm{Mo} \\
\mu \mathrm{g} / \mathrm{L}\end{array}$ & $\begin{array}{c}\mathrm{Cd} \\
\mu \mathrm{g} / \mathrm{L}\end{array}$ & $\begin{array}{c}\mathrm{Sn} \\
\mu \mathrm{g} / \mathrm{L}\end{array}$ \\
\hline P-D-T-1 & 20 & 1:1 & 3 & & 134 & 4.5 & 3.3 & 22 & 3.4 & 24 \\
\hline P-D-T-2 & 20 & $1: 1$ & 3 & & 116 & 3.2 & 3.0 & 23 & 3.3 & 22 \\
\hline P-D-T-3 & 20 & $1: 1$ & 3 & & 143 & 4.6 & 10.7 & 23 & 4.6 & 24 \\
\hline P-D-T-4 & 20 & $1: 1$ & 3 & & 56 & 7.2 & 1.3 & 37 & 3.8 & 13 \\
\hline P-D-T-5 & 20 & 1:1 & 3 & & 52 & 6.8 & 1.3 & 60 & 5.3 & 7 \\
\hline $\begin{array}{l}\text { P-D-T-6 } \\
\text { P-D-T-7 }\end{array}$ & $\begin{array}{l}20 \\
20\end{array}$ & $\begin{array}{l}1: 1 \\
1: 1\end{array}$ & $\begin{array}{l}3 \\
3\end{array}$ & & $\begin{array}{l}<40 \\
72\end{array}$ & $\begin{array}{l}26.0 \\
13.4\end{array}$ & $\begin{array}{l}0.9 \\
0.9\end{array}$ & $\begin{array}{l}42 \\
54\end{array}$ & $\begin{array}{l}5.3 \\
3.3\end{array}$ & $\begin{array}{l}5 \\
14\end{array}$ \\
\hline P-D-T-8 & 20 & 1:1 & 3 & & 69 & 14.2 & 0.9 & 50 & 2.7 & 14 \\
\hline \multirow[t]{4}{*}{ P-D-T-9 } & 20 & $1: 1$ & 3 & & 95 & 9.3 & 0.9 & 52 & 2.5 & 13 \\
\hline & & & & mean & 92 & 9.9 & 2.6 & 40 & 3.8 & 15 \\
\hline & & & & $\mathbf{s}$ & 36 & 7.2 & 3.2 & 15 & 1.0 & 7 \\
\hline & & & & $\%$ rsd & 39 & 72.2 & 122.9 & 37 & 27.7 & 46 \\
\hline P-E-T-1 & 40 & $1: 1$ & 3 & & 92 & 5.5 & 9.1 & 90 & 2.9 & 31 \\
\hline P-E-T-2 & 40 & $1: 1$ & 3 & & 190 & 7.0 & 14.0 & 84 & 5.1 & 44 \\
\hline P-E-T-3 & 40 & $1: 1$ & 3 & & 132 & 4.9 & 12.4 & 102 & 5.1 & 35 \\
\hline P-E-T-4 & 40 & $1: 1$ & 3 & & 131 & 5.5 & 9.2 & 150 & 3.7 & 55 \\
\hline P-E-T-5 & 40 & $1: 1$ & 3 & & 137 & 19.2 & 13.6 & 125 & 4.4 & 58 \\
\hline P-E-T-6 & 40 & $1: 1$ & 3 & & 99 & 7.1 & 9.7 & 136 & 3.8 & 56 \\
\hline P-E-T-7 & 40 & 1:1 & 3 & & 155 & 19.5 & 9.7 & 91 & 3.0 & 61 \\
\hline P-E-T-8 & 40 & 1:1 & 3 & & 164 & 26.6 & 9.2 & 117 & 2.9 & 61 \\
\hline \multirow[t]{4}{*}{ P-E-T-9 } & 40 & $1: 1$ & 3 & & 145 & 16.4 & 9.5 & 95 & 2.7 & 62 \\
\hline & & & & mean & 138 & 12.4 & 10.7 & 110 & 3.8 & 51.6 \\
\hline & & & & & 31 & 8.1 & 2.0 & 23 & 0.9 & 11.9 \\
\hline & & & & $\%$ rsd & 22.1 & 65.1 & 19.0 & 20.9 & 25.1 & 23.1 \\
\hline P-F-T-1 & 70 & $1: 1$ & 3 & & 445 & 21.5 & 85.8 & 371 & 12.5 & 127 \\
\hline P-F-T-2 & 70 & 1:1 & 3 & & 505 & 22.3 & 82.0 & 347 & 12.7 & 131 \\
\hline P-F-T-3 & 70 & $1: 1$ & 3 & & 360 & 14.2 & 73.0 & 339 & 7.7 & 123 \\
\hline P-F-T-4 & 70 & $1: 1$ & 3 & & 364 & 24.0 & 74.8 & 348 & 10.9 & 140 \\
\hline P-F-T-5 & 70 & $1: 1$ & 3 & & 356 & 23.3 & 72.5 & 339 & 9.5 & 134 \\
\hline P-F-T-6 & 70 & $1: 1$ & 3 & & 401 & 20.1 & 79.9 & 363 & 10.2 & 133 \\
\hline P-F-T-7 & 70 & $\mathrm{I}: 1$ & 3 & & 429 & 32.5 & 77.5 & 410 & 11.2 & 147 \\
\hline P-F-T-8 & 70 & 1:1 & 3 & & 409 & 25.0 & 76.9 & 357 & 10.6 & 145 \\
\hline \multirow[t]{4}{*}{ P-F-T-9 } & 70 & $1: 1$ & 3 & & 440 & 22.8 & 76.2 & 374 & 10.6 & 149 \\
\hline & & - & & mean & 412 & 22.9 & 77.6 & 361 & 10.7 & 137 \\
\hline & & & & & 48.8 & 4.8 & 4.3 & 22.3 & 1.5 & 9.3 \\
\hline & & & & $\%$ rsd & 11.8 & 20.9 & 5.6 & 6.2 & 14.1 & 6.8 \\
\hline
\end{tabular}


Table $\mathrm{C}-4$, contd. Final Concentrations of $\mathrm{Ba}, \mathrm{La}$, and $\mathrm{Pb}$ in Leachates from 3-day, 1:1 Tests. Means, sample standard deviations, and relative standard deviations are calculated for three sets of triplicate tests and illustrated in bold type.

\begin{tabular}{|c|c|c|c|c|c|c|c|}
\hline Designation & $\begin{array}{l}\text { temp. } \\
{\left[{ }^{\circ} \mathrm{C}\right]}\end{array}$ & $\begin{array}{c}\text { glass/water } \\
{[\mathrm{g} / \mathrm{g}]}\end{array}$ & $\begin{array}{c}\text { duration } \\
\text { [d] }\end{array}$ & & $\begin{array}{c}\mathrm{Ba} \\
\mu \mathrm{g} / \mathrm{L} \\
\end{array}$ & $\begin{array}{r}\mathrm{La} \\
\mu \mathrm{g} / \mathrm{L} \\
\end{array}$ & $\begin{array}{c}\mathrm{Pb} \\
\mu \mathrm{g} / \mathrm{L} \\
\end{array}$ \\
\hline P-D-T-1 & 20 & $1: 1$ & 3 & & 0.15 & 0.29 & 4.2 \\
\hline P-D-T-2 & 20 & $1: 1$ & 3 & & 0.11 & 0.41 & 4.2 \\
\hline P-D-T-3 & 20 & $1: 1$ & 3 & & 1.62 & 0.36 & 4.7 \\
\hline P-D-T-4 & 20 & $1: 1$ & 3 & & $<0.1$ & 0.27 & 3.0 \\
\hline P-D-T-5 & 20 & 1:1 & 3 & & $<0.1$ & 0.46 & 2.7 \\
\hline P-D-T-6 & 20 & $1: 1$ & 3 & & $<0.1$ & 0.20 & 1.8 \\
\hline P-D-T-7 & 20 & $1: 1$ & 3 & & $<1$ & 0.27 & 2.9 \\
\hline P-D-T-8 & 20 & 1:1 & 3 & & $<1$ & 0.20 & 2.8 \\
\hline \multirow[t]{4}{*}{ P-D-T-9 } & 20 & $1: 1$ & 3 & & $<1$ & 0.21 & 2.2 \\
\hline & & & & mean & 0.6 & 0.3 & 3.2 \\
\hline & & & & $s$ & 0.9 & 0.1 & 1.0 \\
\hline & & & & $\%$ rsd & 137.3 & 31.0 & 30.8 \\
\hline P-E-T-1 & 40 & $1: 1$ & 3 & & 0.17 & 0.39 & 6.5 \\
\hline P-E-T-2 & 40 & $1: 1$ & 3 & & 0.25 & 0.55 & 8.0 \\
\hline P-E-T-3 & 40 & $1: 1$ & 3 & & 0.30 & 0.48 & 6.4 \\
\hline P-E-T-4 & 40 & $1: 1$ & 3 & & 0.19 & 0.55 & 6.0 \\
\hline P-E-T-5 & 40 & $1: 1$ & 3 & & 0.27 & 0.59 & 5.7 \\
\hline P-E-T-6 & 40 & $1: 1$ & 3 & & 0.14 & 0.49 & 5.9 \\
\hline P-E-T-7 & 40 & $1: 1$ & 3 & & $<1$ & 0.51 & 7.4 \\
\hline P-E-T-8 & 40 & $1: 1$ & 3 & & $<1$ & 0.47 & 5.2 \\
\hline \multirow[t]{4}{*}{ P-E-T-9 } & 40 & $1: 1$ & 3 & & $<1$ & 0.52 & 6.5 \\
\hline & & & & mean & 0.2 & 0.5 & 6.4 \\
\hline & & & & & 0.1 & 0.1 & 0.8 \\
\hline & & & & $\%$ rsd & 27.5 & 11.6 & 13.3 \\
\hline P-F-T-I & 70 & $1: 1$ & 3 & & 0.42 & 2.1 & 14.3 \\
\hline P-F-T-2 & 70 & $1: 1$ & 3 & & 0.33 & 1.2 & 14.5 \\
\hline P-F-T-3 & 70 & 1:1 & 3 & & 0.27 & 1.8 & 9.8 \\
\hline P-F-T-4 & 70 & $1: 1$ & 3 & & 0.49 & 1.8 & 13.5 \\
\hline P-F-T-5 & 70 & $1: 1$ & 3 & & 0.38 & 1.7 & 11.9 \\
\hline P-F-T-6 & 70 & 1:1 & 3 & & 2.06 & 2.3 & 13.5 \\
\hline P-F-T-7 & 70 & $1: 1$ & 3 & & $<1$ & 1.9 & 14.1 \\
\hline P-F-T-8 & 70 & $1: 1$ & 3 & & $<1$ & 2.0 & 13.9 \\
\hline \multirow[t]{4}{*}{ P-F-T-9 } & 70 & $1: 1$ & 3 & & $<1$ & 1.8 & 12.9 \\
\hline & & & & mean & 0.7 & 1.8 & 13.2 \\
\hline & & & & & 0.7 & 0.3 & 1.5 \\
\hline & & & & $\%$ rsd & 104.6 & 15.8 & 11.2 \\
\hline
\end{tabular}


Table C-5. Final Concentrations of $\mathrm{Li}, \mathrm{Mg}, \mathrm{Ca}, \mathrm{Ti}, \mathrm{Cr}$, and $\mathrm{Mn}$ in Leachates from 7-day, 1:10 Tests. Means, sample standard deviations, and relative standard deviations are calculated for three sets of triplicate tests and illustrated in bold type.

\begin{tabular}{|c|c|c|c|c|c|c|c|c|c|c|}
\hline Designation & $\begin{array}{l}\text { temp. } \\
{\left[{ }^{\circ} \mathrm{C}\right]}\end{array}$ & $\begin{array}{c}\text { glass/water } \\
{[\mathrm{g} / \mathrm{g}]}\end{array}$ & $\begin{array}{c}\text { duration } \\
\text { [d] }\end{array}$ & & $\begin{array}{r}\mathrm{Li} \\
\mu \mathrm{g} / \mathrm{L}\end{array}$ & $\begin{array}{c}\mathrm{Mg} \\
\mu \mathrm{g} / \mathrm{L}\end{array}$ & $\begin{array}{c}\mathrm{Ca} \\
\mu \mathrm{g} / \mathrm{L}\end{array}$ & $\begin{array}{r}\mathrm{Ti} \\
\mu \mathrm{g} / \mathrm{L}\end{array}$ & $\begin{array}{c}\mathrm{Cr} \\
\mu \mathrm{g} / \mathrm{L}\end{array}$ & $\begin{array}{c}\mathrm{Mn} \\
\mu \mathrm{g} / \mathrm{L}\end{array}$ \\
\hline P-G-T-1 & 20 & $1: 10$ & 7 & & 6.3 & 5.4 & $<100$ & 0.7 & 3.8 & 74 \\
\hline P-G-T-2 & 20 & $1: 10$ & 7 & & 6.7 & 3.3 & $<100$ & 0.8 & 4.0 & 51 \\
\hline P-G-T-3 & 20 & $1: 10$ & 7 & & 7.0 & 4.6 & $<100$ & 0.7 & 5.0 & 50 \\
\hline P-G-T-4 & 20 & $1: 10$ & 7 & & 12.9 & 4.5 & $<70$ & 0.5 & 18.5 & 92 \\
\hline P-G-T-5 & 20 & $1: 10$ & 7 & & 17.9 & 4.7 & $<70$ & 0.4 & 10.8 & 66 \\
\hline P-G-T-6 & 20 & $1: 10$ & 7 & & 15.6 & 3.7 & $<70$ & 0.6 & 6.9 & 57 \\
\hline P-G-T-7 & 20 & $1: 10$ & 7 & & $<4$ & 3.2 & $<100$ & 0.2 & 4.9 & 191 \\
\hline P-G-T-8 & 20 & $1: 10$ & 7 & & $<4$ & 6.0 & $<100$ & 0.8 & 49.3 & 127 \\
\hline \multirow[t]{4}{*}{ P-G-T-9 } & 20 & $1: 10$ & 7 & & $<4$ & 5.1 & $<100$ & 0.9 & 3.8 & 31 \\
\hline & & & & mean & 11.1 & 4.5 & - & 0.6 & 11.9 & 82 \\
\hline & & & & $\mathbf{s}$ & 5.1 & 1.0 & - & 0.2 & 14.8 & 50 \\
\hline & & & & $\%$ rsd & 45.9 & 21.2 & - & 38.7 & 124.7 & 60 \\
\hline P-H-T-1 & 40 & $1: 10$ & 7 & & 8.7 & 3.9 & $<100$ & 2.5 & 8.4 & 5 \\
\hline P-H-T-2 & 40 & $1: 10$ & 7 & & 8.6 & 7.0 & $<100$ & 2.4 & 12.3 & 15 \\
\hline P-H-T-3 & 40 & $1: 10$ & 7 & & 7.9 & 4.0 & $<100$ & 2.6 & 14.7 & 27 \\
\hline P-H-T-4 & 40 & $1: 10$ & 7 & & 16.9 & 4.2 & $<70$ & 1.4 & 7.4 & 8 \\
\hline P-H-T-5 & 40 & $1: 10$ & 7 & & 15.1 & 3.4 & $<70$ & 1.2 & 7.5 & 7 \\
\hline P-H-T-6 & 40 & $1: 10$ & 7 & & 14.5 & 4.8 & $<70$ & 1.5 & 17.2 & 11 \\
\hline P-H-T-7 & 40 & $1: 10$ & 7 & & $<4$ & 4.8 & $<100$ & 1.6 & 18.5 & 28 \\
\hline P-H-T-8 & 40 & $1: 10$ & 7 & & $<4$ & 3.9 & $<100$ & 1.3 & 30.8 & 26 \\
\hline \multirow[t]{4}{*}{ P-H-T-9 } & 40 & $1: 10$ & 7 & & $<4$ & 4.3 & $<100$ & 2.8 & 11.8 & 16 \\
\hline & & & & mean & 11.9 & 4.5 & - & 1.9 & 14.3 & 16 \\
\hline & & & & $s$ & 4.0 & 1.0 & - & 0.6 & 7.4 & 9 \\
\hline & & & & $\%$ rsd & 33.2 & 23.2 & - & 32.7 & 51.9 & 57 \\
\hline P-I-T-I & 70 & $1: 10$ & 7 & & 15.9 & 19.5 & 332 & 48.6 & 104 & 46 \\
\hline P-I-T-2 & 70 & $1: 10$ & 7 & & 15.5 & 9.5 & 292 & 46.7 & 107 & 39 \\
\hline P-I-T-3 & 70 & $1: 10$ & 7 & & 13.9 & 13.8 & 327 & 49.3 & 108 & 50 \\
\hline P-I-T-4 & 70 & $1: 10$ & 7 & & 18.8 & 9.8 & 221 & 43.4 & 92 & 69 \\
\hline P-I-T-5 & 70 & $1: 10$ & 7 & & 14.1 & 9.2 & 235 & 42.8 & 94 & 48 \\
\hline P-I-T-6 & 70 & $1: 10$ & 7 & & 14.0 & 8.2 & 208 & 46.7 & 99 & 86 \\
\hline P-I-T-7 & 70 & $1: 10$ & 7 & & $<4$ & 12.1 & 377 & 62.1 & 131 & 87 \\
\hline P-I-T-8 & 70 & $1: 10$ & 7 & & $<4$ & 12.0 & 405 & 66.7 & 129 & 80 \\
\hline \multirow[t]{4}{*}{ P-I-T-9 } & 70 & $1: 10$ & 7 & & $<4$ & 11.5 & 361 & 57.9 & 111 & 36 \\
\hline & & . & & mean & 15.3 & 11.8 & 307 & 51.6 & 108 & 60 \\
\hline & & & & $\mathbf{s}$ & 1.9 & 3.4 & 72 & 8.6 & 14 & 21 \\
\hline & & & & $\%$ rsd & 12.4 & 28.9 & 23 & 16.6 & 13 & 34 \\
\hline
\end{tabular}


Table C-5, contd. Final Concentrations of $\mathrm{Fe}, \mathrm{Ni}, \mathrm{Zr}, \mathrm{Mo}, \mathrm{Cd}$, and $\mathrm{Sn}$ in Leachates from 7-day, 1:10 Tests. Means, sample standard deviations, and relative standard deviations are calculated for three sets of triplicate tests and illustrated in bold type.

\begin{tabular}{|c|c|c|c|c|c|c|c|c|c|c|}
\hline Designation & $\begin{array}{l}\text { temp. } \\
{\left[{ }^{\circ} \mathrm{C}\right]}\end{array}$ & $\begin{array}{c}\text { glass/water } \\
{[\mathrm{g} / \mathrm{g}]}\end{array}$ & $\begin{array}{l}\text { duration } \\
\text { [d] }\end{array}$ & & $\begin{array}{c}\mathrm{Fe} \\
\mu \mathrm{g} / \mathrm{L}\end{array}$ & $\begin{array}{c}\mathrm{Ni} \\
\mu \mathrm{g} / \mathrm{L} \\
\end{array}$ & $\begin{array}{c}\mathrm{Zr} \\
\mu \mathrm{g} / \mathrm{L}\end{array}$ & $\begin{array}{c}\text { Mo } \\
\mu \mathrm{g} / \mathrm{L}\end{array}$ & $\begin{array}{c}\mathrm{Cd} \\
\mu \mathrm{g} / \mathrm{L}\end{array}$ & $\begin{array}{r}\mathrm{Sn} \\
\mu \mathrm{g} / \mathrm{L} \\
\end{array}$ \\
\hline P-G-T-1 & 20 & $1: 10$ & 7 & & $<40$ & 1.87 & 0.84 & 6.4 & $<0.4$ & 0.49 \\
\hline P-G-T-2 & 20 & $1: 10$ & 7 & & $<40$ & 1.72 & 0.43 & 18.2 & $<0.4$ & 0.83 \\
\hline P-G-T-3 & 20 & $1: 10$ & 7 & & $<40$ & 5.39 & 0.34 & 13.5 & $<0.4$ & 0.51 \\
\hline P-G-T-4 & 20 & $1: 10$ & 7 & & $<60$ & 17.50 & 0.27 & 26.8 & 0.8 & 0.17 \\
\hline P-G-T-5 & 20 & $1: 10$ & 7 & & $<60$ & 9.99 & 0.23 & 12.4 & 0.9 & 0.16 \\
\hline P-G-T-6 & 20 & $1: 10$ & 7 & & $<60$ & 7.27 & 0.28 & 15.4 & 1.6 & 0.74 \\
\hline P-G-T-7 & 20 & $1: 10$ & 7 & & $<20$ & 29.2 & $<0.06$ & 20.2 & $<0.3$ & $<0.1$ \\
\hline P-G-T-8 & 20 & $1: 10$ & 7 & & 249 & 27.0 & 0.26 & 21.6 & 0.9 & 0.23 \\
\hline \multirow[t]{4}{*}{ P-G-T-9 } & 20 & $1: 10$ & 7 & & $<20$ & 8.08 & 0.26 & 28.5 & 0.4 & 1.25 \\
\hline & & & & mean & 249 & 12.0 & 0.4 & 18.1 & 0.9 & 0.5 \\
\hline & & & & & - & 10.3 & 0.2 & 7.1 & 0.4 & 0.4 \\
\hline & & & & $\%$ rsd & - & 85.6 & 55.6 & 39.0 & 47.4 & 69.5 \\
\hline P-H-T-1 & 40 & $1: 10$ & 7 & & $<40$ & $<1$ & 6.66 & 20.8 & 0.7 & 8.67 \\
\hline P-H-T-2 & 40 & $1: 10$ & 7 & & $<40$ & 107.24 & 7.21 & 32.2 & 0.7 & 7.34 \\
\hline P-H-T-3 & 40 & $1: 10$ & 7 & & 91 & 1.62 & 9.60 & 23.7 & 0.8 & 7.18 \\
\hline P-H-T-4 & 40 & $1: 10$ & 7 & & $<60$ & $<4$ & 3.46 & 28.5 & 0.9 & 9.13 \\
\hline P-H-T-5 & 40 & $1: 10$ & 7 & & $<60$ & $<4^{\circ}$ & 4.34 & 32.7 & 0.7 & 10.8 \\
\hline P-H-T-6 & 40 & $1: 10$ & 7 & & $<60$ & $<4$ & 3.65 & 61.5 & 0.3 & 6.87 \\
\hline P-H-T-7 & 40 & $1: 10$ & 7 & & 47 & 9.88 & 4.14 & 47.4 & 0.9 & 5.10 \\
\hline P-H-T-8 & 40 & $1: 10$ & 7 & & 40 & 6.39 & 3.78 & 59.5 & 0.3 & 2.92 \\
\hline \multirow[t]{4}{*}{ P-H-T-9 } & 40 & $1: 10$ & 7 & & 67 & 6.81 & 4.47 & 40.6 & 0.7 & 9.90 \\
\hline & & & & mean & 61 & 26.4 & 5.3 & 38.5 & 0.7 & 7.5 \\
\hline & & & & & 23 & 45.3 & 2.1 & 14.8 & 0.2 & 2.5 \\
\hline & & & & $\%$ rsd & 38 & 171.6 & 40.0 & 38.5 & 35.4 & 32.5 \\
\hline P-I-T-I & 70 & $1: 10$ & 7 & & 644 & 43.3 & 542 & 93.2 & 43.0 & 59.4 \\
\hline P-I-T-2 & 70 & $1: 10$ & 7 & & 599 & 39.7 & 520 & 93.8 & 39.8 & 58.0 \\
\hline P-I-T-3 & 70 & $1: 10$ & 7 & & 619 & 40.8 & 534 & 92.0 & 43.3 & 58.5 \\
\hline P-I-T-4 & 70 & $1: 10$ & 7 & & 524 & 45.7 & 435 & 151.7 & 34.2 & 55.6 \\
\hline P-I-T-5 & 70 & $1: 10$ & 7 & & 434 & 34.9 & 398 & 141.9 & 28.0 & 46.5 \\
\hline P-I-T-6 & 70 & $1: 10$ & 7 & & 508 & 39.4 & 435 & 115.3 & 34.8 & 47.4 \\
\hline P-I-T-7 & 70 & $1: 10$ & 7 & & 609 & 67.8 & 500 & 142.6 & 41.0 & 54.1 \\
\hline P-I-T-8 & 70 & $1: 10$ & 7 & & 715 & 59.0 & 530 & 130.6 & 47.4 & 60.9 \\
\hline \multirow[t]{3}{*}{ P-I-T-9 } & 70 & $1: 10$ & 7 & & 625 & 52.2 & 488 & 153.7 & 41.3 & 63.5 \\
\hline & & - & & mean & 586 & 47.0 & 487 & 124 & 39.2 & 56.0 \\
\hline & & & & $\begin{array}{l}\text { s } \\
\text { \% rsd }\end{array}$ & $\begin{array}{c}84 \\
14.3\end{array}$ & $\begin{array}{l}10.7 \\
22.8\end{array}$ & $\begin{array}{c}52 \\
10.7\end{array}$ & $\begin{array}{c}26 \\
20.8\end{array}$ & $\begin{array}{c}5.9 \\
15.0\end{array}$ & $\begin{array}{c}5.8 \\
10.4\end{array}$ \\
\hline
\end{tabular}


Table C-5, contd. Final Concentrations of $\mathrm{Ba}, \mathrm{La}$, and $\mathrm{Pb}$ in Leachates from 7-day, 1:10 Tests. Means, sample standard deviations, and relative standard deviations are calculated for three sets of triplicate tests and illustrated in bold type.

\begin{tabular}{|c|c|c|c|c|c|c|c|}
\hline Designation & $\begin{array}{l}\text { temp. } \\
{\left[{ }^{\circ} \mathrm{C}\right]}\end{array}$ & $\begin{array}{c}\text { glass/water } \\
{[\mathrm{g} / \mathrm{g}]}\end{array}$ & $\begin{array}{c}\text { duration } \\
\text { [d] }\end{array}$ & & $\begin{array}{c}\mathrm{Ba} \\
\mu \mathrm{g} / \mathrm{L} \\
\end{array}$ & $\begin{array}{r}\mathrm{La} \\
\mu \mathrm{g} / \mathrm{L} \\
\end{array}$ & $\begin{array}{c}\mathrm{Pb} \\
\mu \mathrm{g} / \mathrm{L} \\
\end{array}$ \\
\hline P-G-T-1 & 20 & $1: 10$ & 7 & & 1.72 & 0.11 & 0.98 \\
\hline P-G-T-2 & 20 & $1: 10$ & 7 & & $<0.09$ & 1.78 & 0.50 \\
\hline P-G-T-3 & 20 & $1: 10$ & 7 & & $<0.09$ & $<0.05$ & 0.40 \\
\hline P-G-T-4 & 20 & $1: 10$ & 7 & & 0.12 & 0.10 & 0.61 \\
\hline P-G-T-5 & 20 & $1: 10$ & 7 & & 0.09 & 0.05 & 0.51 \\
\hline P-G-T-6 & 20 & $1: 10$ & 7 & & 0.13 & 0.05 & 1.86 \\
\hline P-G-T-7 & 20 & $1: 10$ & 7 & & $<0.2$ & 0.02 & $<0.2$ \\
\hline P-G-T-8 & 20 & $1: 10$ & 7 & & $<0.2$ & 0.29 & 0.32 \\
\hline \multirow[t]{4}{*}{ P-G-T-9 } & 20 & $1: 10$ & 7 & & $<0.2$ & 0.03 & 0.28 \\
\hline & & & & mean & 0.5 & 0.3 & 0.7 \\
\hline & & & & $\mathbf{s}$ & 0.8 & 0.6 & 0.5 \\
\hline & & & & $\%$ rsd & 156.1 & 199.2 & 76.6 \\
\hline P-H-T-1 & 40 & $1: 10$ & 7 & & 0.12 & 0.11 & 1.76 \\
\hline P-H-T-2 & 40 & $1: 10$ & 7 & & 0.12 & 0.14 & 16.0 \\
\hline P-H-T-3 & 40 & $1: 10$ & 7 & & $<0.09$ & 0.11 & 2.21 \\
\hline P-H-T-4 & 40 & $1: 10$ & 7 & & 0.11 & 0.09 & 1.19 \\
\hline P-H-T-5 & 40 & 1:10 & 7 & & 0.11 & 0.06 & 1.25 \\
\hline P-H-T-6 & 40 & $1: 10$ & 7 & & 0.12 & 0.06 & 1.71 \\
\hline P-H-T-7 & 40 & $1: 10$ & 7 & & $<0.2$ & 0.06 & 1.55 \\
\hline P-H-T-8 & 40 & $1: 10$ & 7 & & $<0.2$ & 0.06 & 0.49 \\
\hline \multirow[t]{4}{*}{ P-H-T-9 } & 40 & $1: 10$ & 7 & & $<0.2$ & 0.08 & 2.10 \\
\hline & & & & mean & 0.1 & 0.1 & 3.1 \\
\hline & & & & & 0.01 & 0.03 & 4.8 \\
\hline & & & & $\%$ rsd & 6.5 & 33.6 & 154.3 \\
\hline P-I-T-1 & 70 & $1: 10$ & 7 & & 0.72 & 8.60 & 48.7 \\
\hline P-I-T-2 & 70 & $1: 10$ & 7 & & 0.54 & 8.60 & 47.3 \\
\hline P-I-T-3 & 70 & $1: 10$ & 7 & & 0.62 & 9.39 & 48.0 \\
\hline P-I-T-4 & 70 & $1: 10$ & 7 & & 0.74 & 8.33 & 43.4 \\
\hline P-I-T-5 & 70 & $1: 10$ & 7 & & 0.60 & 7.69 & 37.8 \\
\hline P-I-T-6 & 70 & $1: 10$ & 7 & & 0.69 & 8.65 & 43.3 \\
\hline P-I-T-7 & 70 & $1: 10$ & 7 & & 0.57 & 8.63 & 45.3 \\
\hline P-I-T-8 & 70 & $1: 10$ & 7 & & 0.32 & 9.00 & 51.3 \\
\hline \multirow[t]{4}{*}{ P-I-T-9 } & 70 & $1: 10$ & 7 & & 1.08 & 8.50 & 44.8 \\
\hline & & & & mean & 0.7 & 8.6 & 45.6 \\
\hline & & & & & 0.2 & 0.5 & 3.9 \\
\hline & & & & $\%$ rsd & 31.1 & 5.3 & 8.6 \\
\hline
\end{tabular}


Table C-6. Final Concentrations of $\mathrm{Li}, \mathrm{Mg}, \mathrm{Ca}, \mathrm{Ti}, \mathrm{Cr}$, and $\mathrm{Mn}$ in Leachates from 7-day, 1:1 Tests. Means, sample standard deviations, and relative standard deviations are calculated for three sets of triplicate tests and illustrated in bold type.

\begin{tabular}{|c|c|c|c|c|c|c|c|c|c|c|}
\hline Designation & $\begin{array}{l}\text { temp. } \\
{\left[{ }^{\circ} \mathrm{C}\right]}\end{array}$ & $\begin{array}{c}\text { glass/water } \\
{[\mathrm{g} / \mathrm{g}]}\end{array}$ & $\begin{array}{c}\text { duration } \\
\text { [d] }\end{array}$ & & $\begin{array}{c}\mathrm{Li} \\
\mu \mathrm{g} / \mathrm{L} \\
\end{array}$ & $\begin{array}{c}\mathrm{Mg} \\
\mu \mathrm{g} / \mathrm{L} \\
\end{array}$ & $\begin{array}{c}\mathrm{Ca} \\
\mu \mathrm{g} / \mathrm{L}\end{array}$ & $\begin{array}{c}\mathrm{Ti} \\
\mu \mathrm{g} / \mathrm{L}\end{array}$ & $\begin{array}{c}\mathrm{Cr} \\
\mu \mathrm{g} / \mathrm{L}\end{array}$ & $\begin{array}{c}\mathrm{Mn} \\
\mu \mathrm{g} / \mathrm{L}\end{array}$ \\
\hline P-J-T-1 & 20 & $1: 1$ & 7 & & 8.77 & 10.0 & 132 & 3.78 & 24.6 & 37 \\
\hline P-J-T-2 & 20 & $1: 1$ & 7 & & 8.20 & 24.2 & 166 & 7.14 & 25.4 & 38 \\
\hline P-J-T-3 & 20 & $1: 1$ & 7 & & 7.70 & 26.6 & 226 & 5.45 & 22.7 & 27 \\
\hline P-J-T-4 & 20 & $1: 1$ & 7 & & $<10$ & 7.4 & 126 & 3.98 & 39.7 & 95 \\
\hline P-J-T-5 & 20 & $1: 1$ & 7 & & $<10$ & 6.8 & 79 & 3.35 & 30.4 & 46 \\
\hline P-J-T-6 & 20 & $1: 1$ & 7 & & $<10$ & 4.3 & 76 & 3.86 & 35.7 & 52 \\
\hline P-J-T-7 & 20 & $1: 1$ & 7 & & $<4$ & 13.5 & 131 & 4.61 & 67.4 & 206 \\
\hline P-J-T-8 & 20 & $1: 1$ & 7 & & $<4$ & 14.6 & 102 & 5.37 & 39.6 & 196 \\
\hline \multirow[t]{4}{*}{ P-J-T-9 } & 20 & $1: 1$ & 7 & & $<4$ & 19.0 & 126 & 5.10 & 58.5 & 223 \\
\hline & & & & mean & 8.23 & 14.1 & 129 & 4.7 & 38.2 & 102 \\
\hline & & & & & 0.53 & 7.9 & 46 & 1.2 & 15.5 & 82 \\
\hline & & & & $\%$ rsd & 6.50 & 56.0 & 36 & 24.7 & 40.6 & 80 \\
\hline P-K-T-1 & 40 & 1:1 & 7 & & 11.7 & 12.0 & 379 & 12.2 & 38.3 & 33 \\
\hline P-K-T-2 & 40 & $1: 1$ & 7 & & 10.2 & 10.8 & 363 & 11.0 & 34.8 & 32 \\
\hline P-K-T-3 & 40 & $1: 1$ & 7 & & 9.94 & 14.2 & 394 & 12.1 & 39.0 & 21 \\
\hline P-K-T-4 & 40 & $1: 1$ & 7 & & $<10$ & 8.9 & 219 & 8.5 & 36.4 & 13 \\
\hline P-K-T-5 & 40 & 1:1 & 7 & & $<10$ & 6.6 & 222 & 9.2 & 40.1 & 36 \\
\hline P-K-T-6 & 40 & 1:1 & 7 & & $<10$ & 12.8 & 340 & 12.9 & 65.3 & 45 \\
\hline P-K-T-7 & 40 & $1: 1$ & 7 & & $<4$ & 18.3 & 430 & 10.1 & 39.1 & 19 \\
\hline P-K-T-8 & 40 & 1:1 & 7 & & $<4$ & 21.9 & 487 & 11.0 & 40.8 & 24 \\
\hline \multirow[t]{4}{*}{ P-K-T-9 } & 40 & $1: 1$ & 7 & & $<4$ & 17.6 & 453 & 10.0 & 52.5 & 43 \\
\hline & & & & mean & 10.6 & 13.7 & 365 & 10.8 & 42.9 & 30 \\
\hline & & & & & 1.0 & 4.9 & 94 & 1.5 & 9.8 & 11 \\
\hline & & & & $\%$ rsd & 9.1 & 35.5 & 26 & 13.5 & 22.8 & 37 \\
\hline P-L-T-1 & 70 & $1: 1$ & 7 & & 38.9 & 26 & 1070 & 30.5 & 116 & 36 \\
\hline P-L-T-2 & 70 & 1:1 & 7 & & 40.6 & 30 & 1222 & 33.5 & 111 & 361 \\
\hline P-L-T-3 & 70 & $1: 1$ & 7 & & 40.8 & 31 & 1279 & 32.4 & 108 & 85 \\
\hline P-L-T-4 & 70 & $1: 1$ & 7 & & $<10$ & 14 & 420 & 25.6 & 106 & 51 \\
\hline P-L-T-5 & 70 & $1: 1$ & 7 & & $<10$ & 15 & 323 & 21.8 & 82 & 32 \\
\hline P-L-T-6 & 70 & $1: 1$ & 7 & & $<10$ & 13 & 442 & 27.1 & 101 & 41 \\
\hline P-L-T-7 & 70 & $1: 1$ & 7 & & 39.6 & 35 & 1259 & 39.1 & 106 & 56 \\
\hline P-L-T-8 & 70 & $1: 1$ & 7 & & 41.3 & 36 & 1259 & 31.3 & 96 & 32 \\
\hline \multirow[t]{4}{*}{ P-L-T-9 } & 70 & $1: 1$ & 7 & & 33.8 & 32 & 1203 & 28.0 & 98 & 29 \\
\hline & & . & & mean & 39.2 & 25.7 & 942 & 29.9 & 102.8 & 80 \\
\hline & & & & & 2.8 & 9.4 & 416 & 5.0 & 9.9 & 107 \\
\hline & & & & $\%$ rsd & 7.1 & 36.5 & 44 & 16.8 & 9.6 & 133 \\
\hline
\end{tabular}


Table C-6, contd. Final Concentrations of $\mathrm{Fe}, \mathrm{Ni}, \mathrm{Zr}, \mathrm{Mo}, \mathrm{Cd}$, and $\mathrm{Sn}$ in Leachates from 7-day, 1:1 Tests. Means, sample standard deviations, and relative standard deviations are calculated for three sets of triplicate tests and illustrated in bold type.

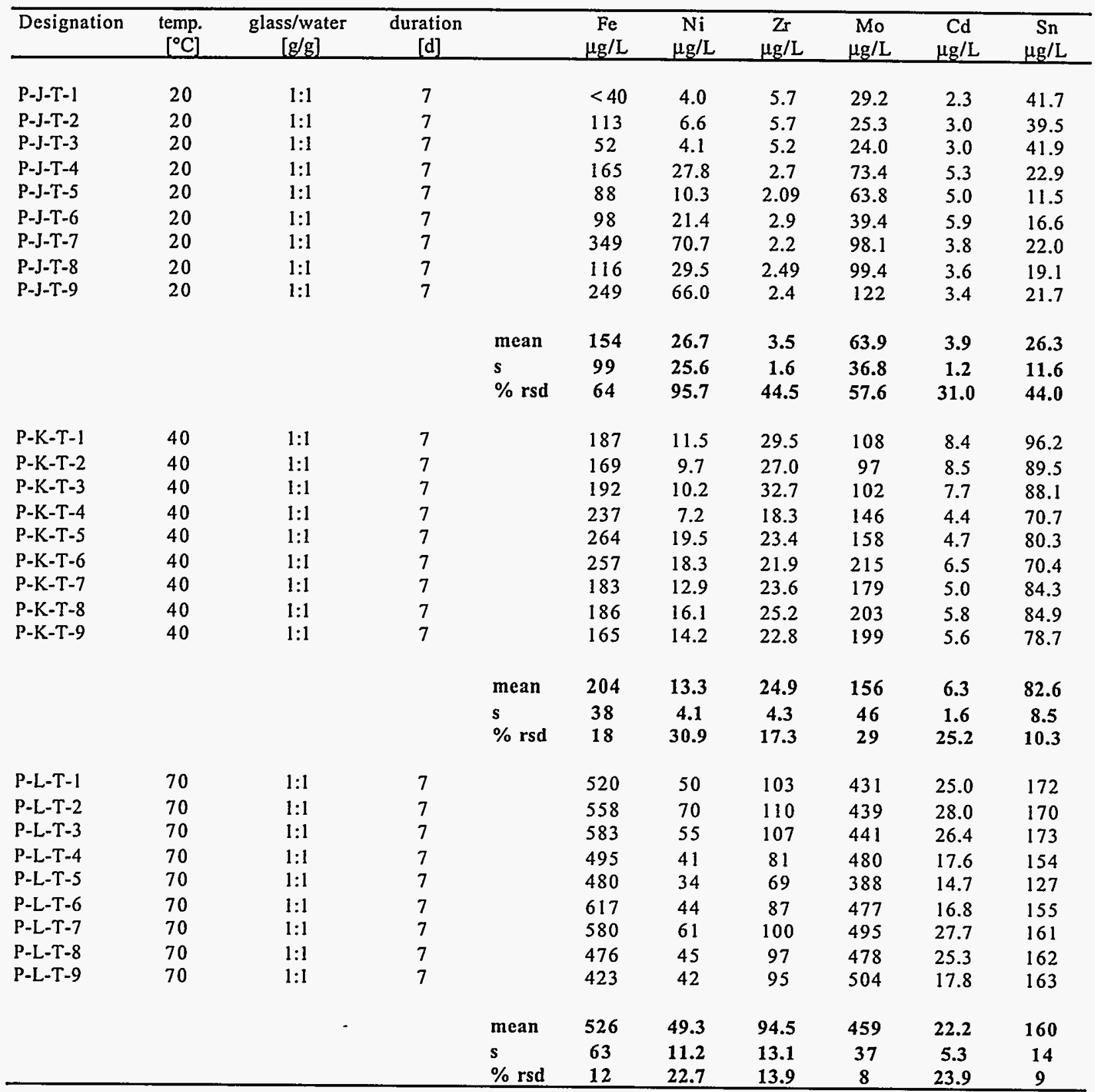


Table C-6, contd. Final Concentrations of $\mathrm{Ba}, \mathrm{La}$, and $\mathrm{Pb}$ in Leachates from 7-day, 1:1 Tests. Means, sample standard deviations, and relative standard deviations are calculated for three sets of triplicate tests and illustrated in bold type.

\begin{tabular}{|c|c|c|c|c|c|c|c|}
\hline Designation & $\begin{array}{l}\text { temp. } \\
{\left[{ }^{\circ} \mathrm{C}\right]}\end{array}$ & $\begin{array}{c}\text { glass/water } \\
{[\mathrm{g} / \mathrm{g}]}\end{array}$ & $\begin{array}{c}\text { duration } \\
\text { [d] }\end{array}$ & & $\begin{array}{c}\mathrm{Ba} \\
\mu \mathrm{g} / \mathrm{L} \\
\end{array}$ & $\begin{array}{c}\mathrm{La} \\
\mu \mathrm{g} / \mathrm{L} \\
\end{array}$ & $\begin{array}{c}\mathrm{Pb} \\
\mu \mathrm{g} / \mathrm{L}\end{array}$ \\
\hline P-J-T-1 & 20 & $1: 1$ & 7 & & 0.15 & 0.84 & 2.91 \\
\hline P-J-T-2 & 20 & $1: 1$ & 7 & & 0.38 & 0.41 & 3.68 \\
\hline P-J-T-3 & 20 & $1: 1$ & 7 & & 0.36 & 0.36 & 3.51 \\
\hline P-J-T-4 & 20 & $1: 1$ & 7 & & 0.38 & 0.58 & 6.33 \\
\hline P-J-T-5 & 20 & $1: 1$ & 7 & & 0.17 & 0.98 & 11.9 \\
\hline P-J-T-6 & 20 & $1: 1$ & 7 & & 0.15 & 0.68 & 4.59 \\
\hline P-J-T-7 & 20 & $1: 1$ & 7 & & 0.85 & 1.05 & 4.31 \\
\hline P-J-T-8 & 20 & $1: 1$ & 7 & & $<0.2$ & 0.61 & 5.10 \\
\hline \multirow[t]{4}{*}{ P-J-T-9 } & 20 & $1: 1$ & 7 & & $<0.2$ & 0.59 & 4.19 \\
\hline & & & & mean & 0.4 & 0.7 & 5.2 \\
\hline & & & & & 0.2 & 0.2 & 2.7 \\
\hline & & & & $\%$ rsd & 70.6 & 35.2 & 52.6 \\
\hline P-K-T-1 & 40 & $1: 1$ & 7 & & 0.41 & 0.90 & 10.0 \\
\hline P-K-T-2 & 40 & $1: 1$ & 7 & & 0.19 & 0.93 & 10.2 \\
\hline P-K-T-3 & 40 & $1: 1$ & 7 & & 0.21 & 0.86 & 10.1 \\
\hline P-K-T-4 & 40 & $1: 1$ & 7 & & 1.58 & 0.79 & 7.95 \\
\hline P-K-T-5 & 40 & 1:1 & 7 & & 0.35 & 0.77 & 8.65 \\
\hline P-K-T-6 & 40 & $1: 1$ & 7 & & 0.27 & 0.96 & 9.49 \\
\hline P-K-T-7 & 40 & 1:1 & 7 & & $<0.2$ & 0.81 & 8.25 \\
\hline P-K-T-8 & 40 & $1: 1$ & 7 & & $<0.2$ & 0.89 & 9.33 \\
\hline \multirow[t]{4}{*}{ P-K-T-9 } & 40 & $1: 1$ & 7 & & $<0.2$ & 0.84 & 7.97 \\
\hline & & & & mean & 0.5 & 0.9 & 9.1 \\
\hline & & & & & 0.5 & 0.1 & 0.9 \\
\hline & & & & $\%$ rsd & 106.7 & 7.6 & 10.1 \\
\hline P-L-T-1 & 70 & 1:1 & 7 & & 0.55 & 3.29 & 22.7 \\
\hline P-L-T-2 & 70 & $1: 1$ & 7 & & 0.55 & 3.56 & 22.4 \\
\hline P-L-T-3 & 70 & $1: 1$ & 7 & & 0.50 & 3.34 & 23.2 \\
\hline P-L-T-4 & 70 & $1: 1$ & 7 & & 0.63 & 2.42 & 17.9 \\
\hline P-L-T-5 & 70 & $1: 1$ & 7 & & 0.46 & 1.99 & 13.8 \\
\hline P-L-T-6 & 70 & $1: 1$ & 7 & & 0.49 & 2.40 & 19.7 \\
\hline P-L-T-7 & 70 & $1: 1$ & 7 & & $\bullet 0.35$ & 3.32 & 33.3 \\
\hline P-L-T-8 & 70 & $1: 1$ & 7 & & 0.26 & 2.83 & 23.3 \\
\hline \multirow[t]{4}{*}{ P-L-T-9 } & 70 & $1: 1$ & 7 & & $<0.2$ & 2.76 & 19.1 \\
\hline & & & & mean & 0.5 & 2.9 & 21.7 \\
\hline & & & & & 0.1 & 0.5 & 5.3 \\
\hline & & & & $\%$ rsd & 25.0 & 18.6 & 24.6 \\
\hline
\end{tabular}




\section{APPENDIX D. ANALYSIS OF VARIANCE BY GLASS/WATER MASS RATIO}

Figure D-1. One-Way ANOVA for Na Concentration in Leachates from 3-day, $20^{\circ} \mathrm{C}, 1: 1$, and 1:10 Tests by Glass/Water Mass Ratio Duration.

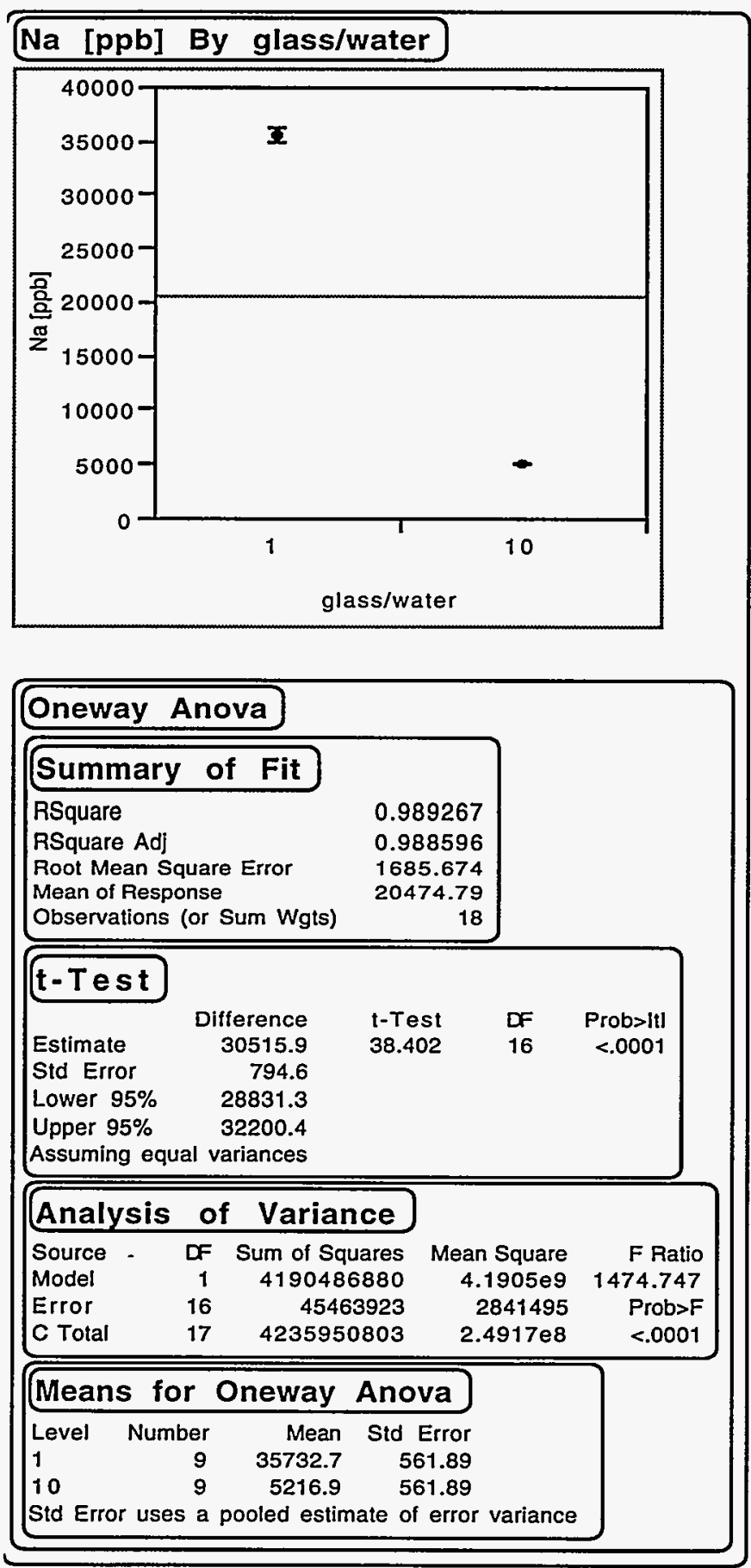


Figure D-1, contd. One-Way ANOVA for Si Concentration in Leachates from 3-day, $20^{\circ} \mathrm{C}, 1: 1$, and 1:10 Tests by Glass/Water Mass Ratio Duration.

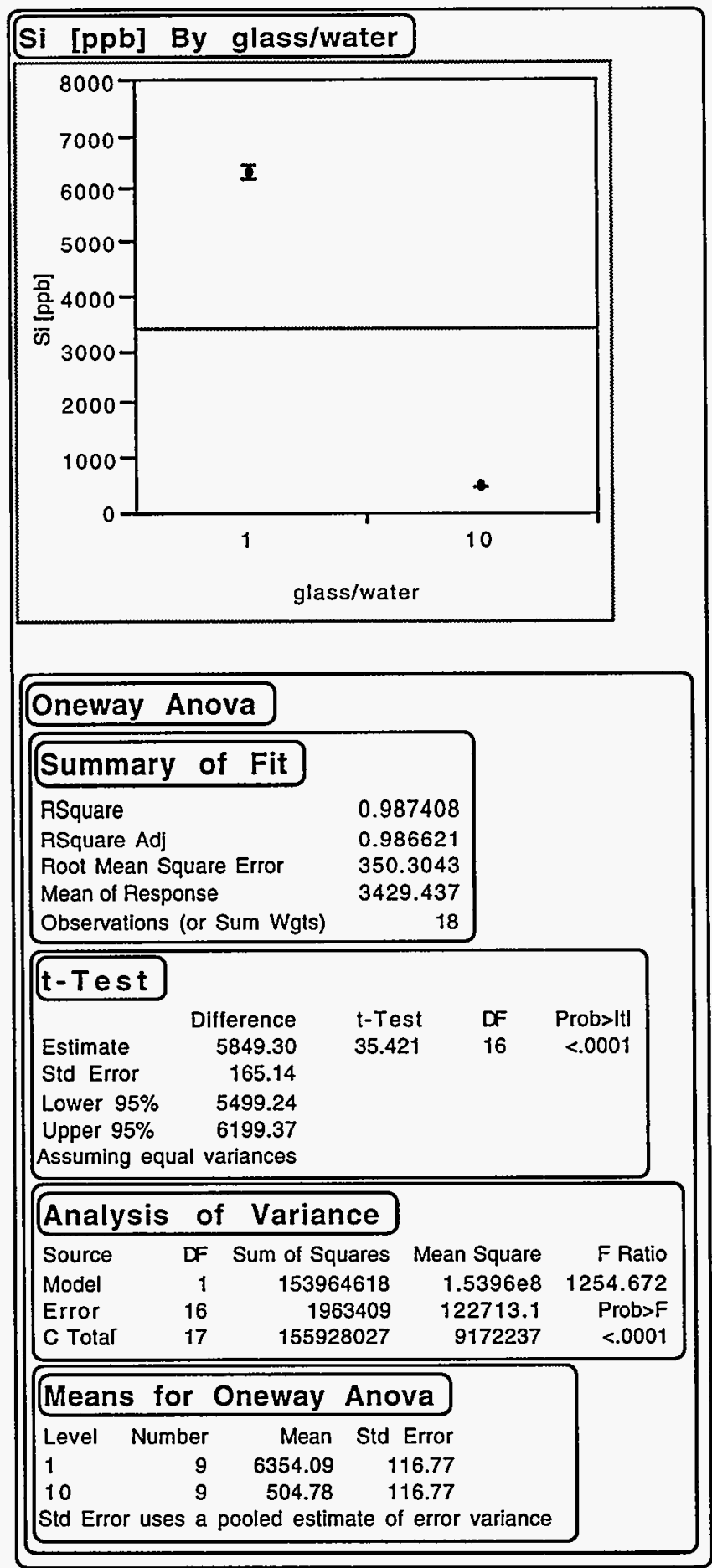


Figure D-1, contd. One-Way ANOVA for B Concentration in Leachates from 3-day, $20^{\circ} \mathrm{C}, 1: 1$, and 1:10 Tests by Glass/Water Mass Ratio Duration.

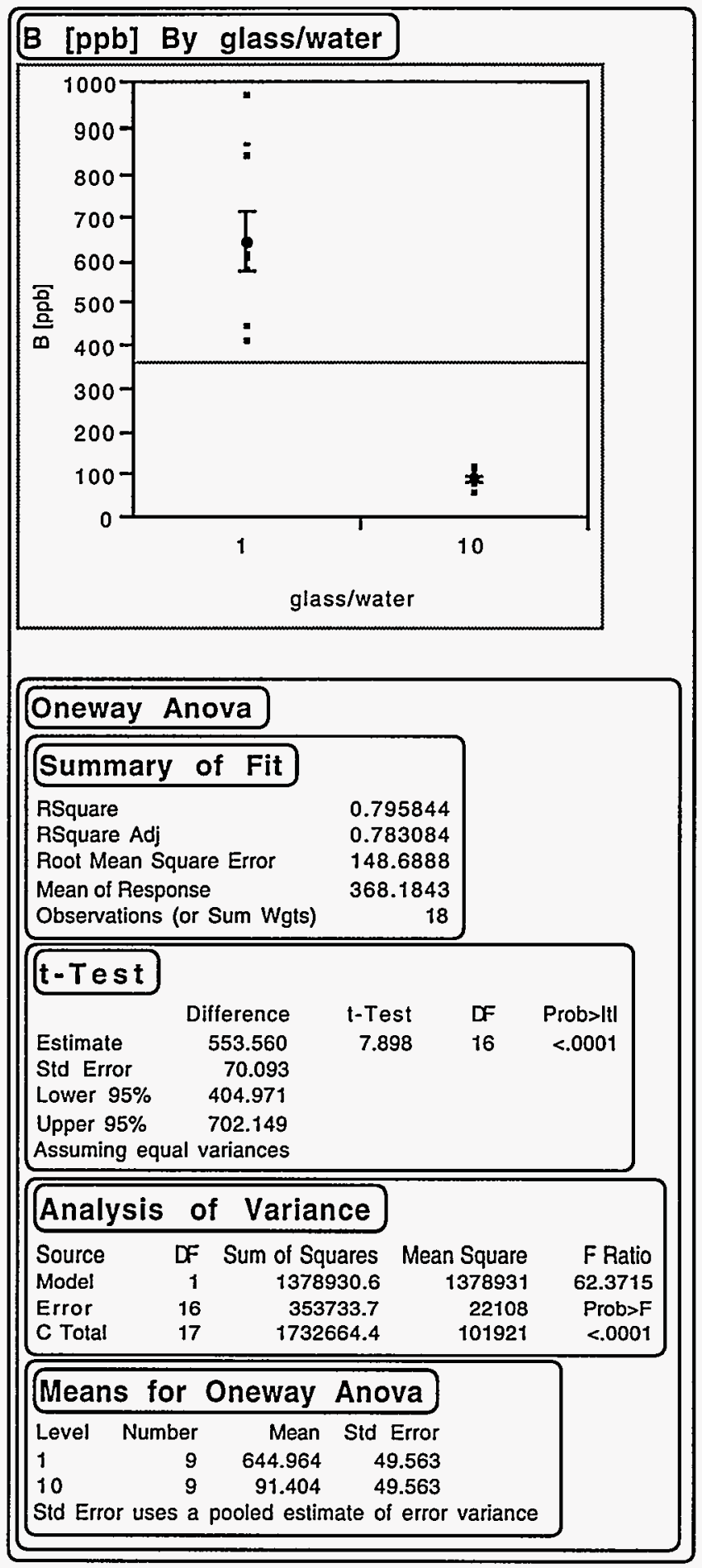


Figure D-2. One-Way ANOVA for Na Concentration in Leachates from 3-day, $40^{\circ} \mathrm{C}, 1: 1$, and 1:10 Tests by Glass/Water Mass Ratio Duration.

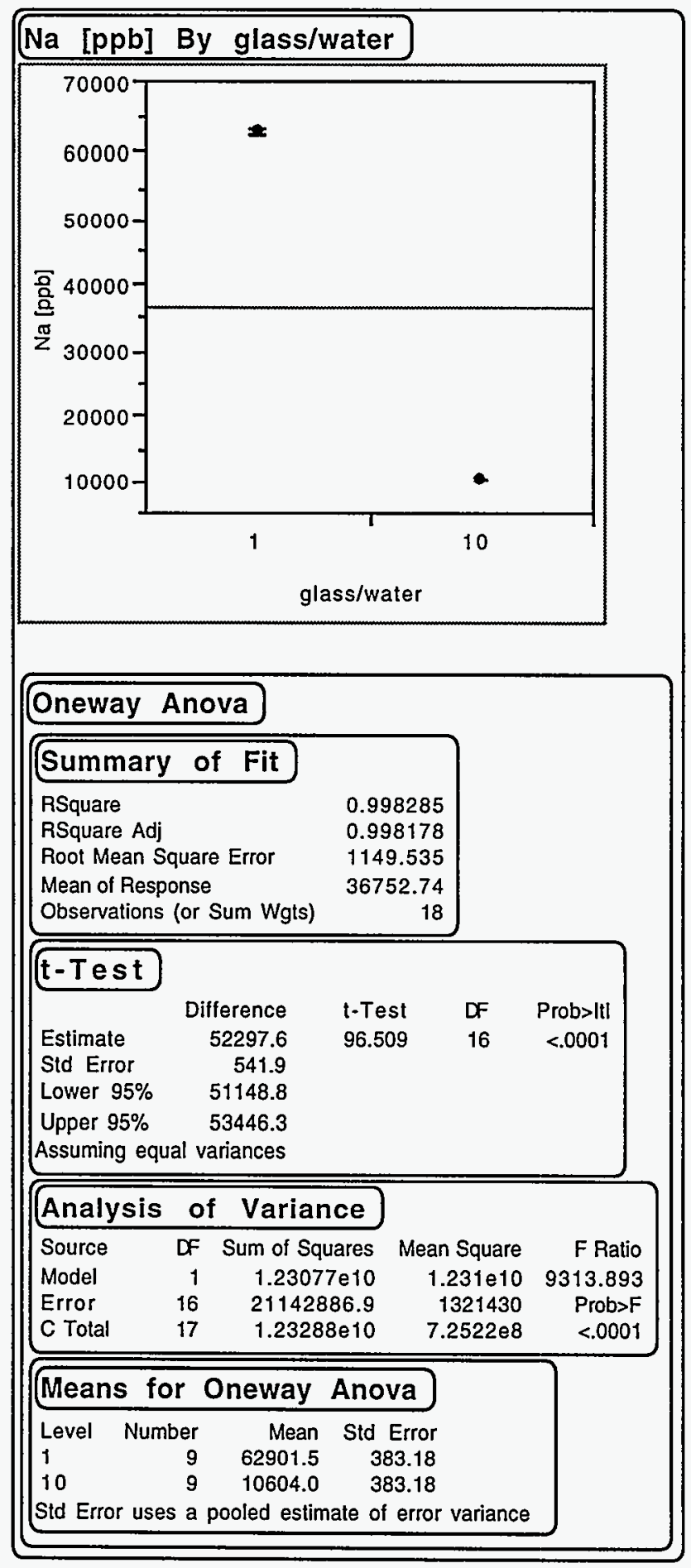


Figure D-2, contd. One-Way ANOVA for Si Concentration in Leachates from 3-day, $40^{\circ} \mathrm{C}, 1: 1$, and 1:10 Tests by Glass/Water Mass Ratio Duration.

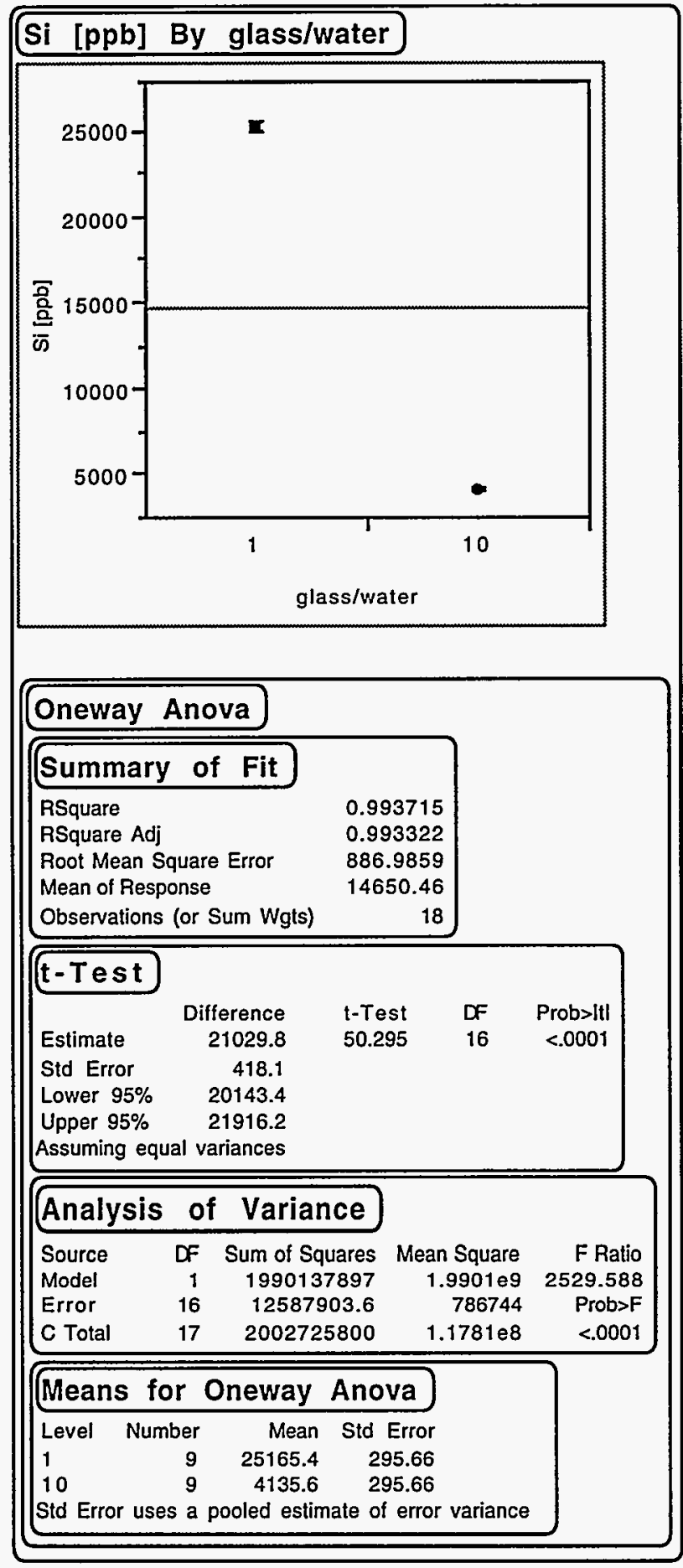


Figure D-2, contd. One-Way ANOVA for B Concentration in Leachates from 3-day, $40^{\circ} \mathrm{C}, 1: 1$, and 1:10 Tests by Glass/Water Mass Ratio Duration.

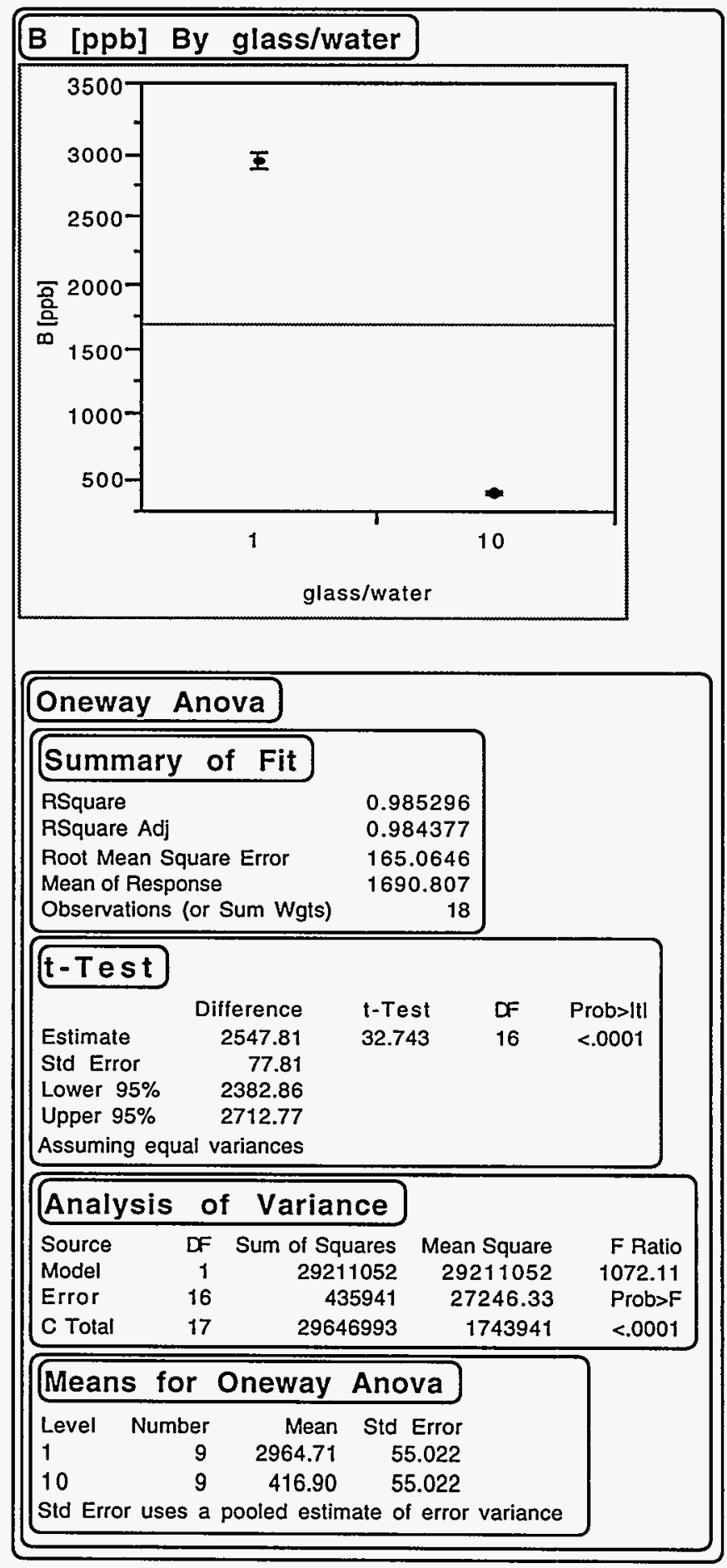


Figure D-3. One-Way ANOVA for Na Concentration in Leachates from 3-day, $70^{\circ} \mathrm{C}, 1: 1$, and 1:10 Tests by Glass/Water Mass Ratio Duration.

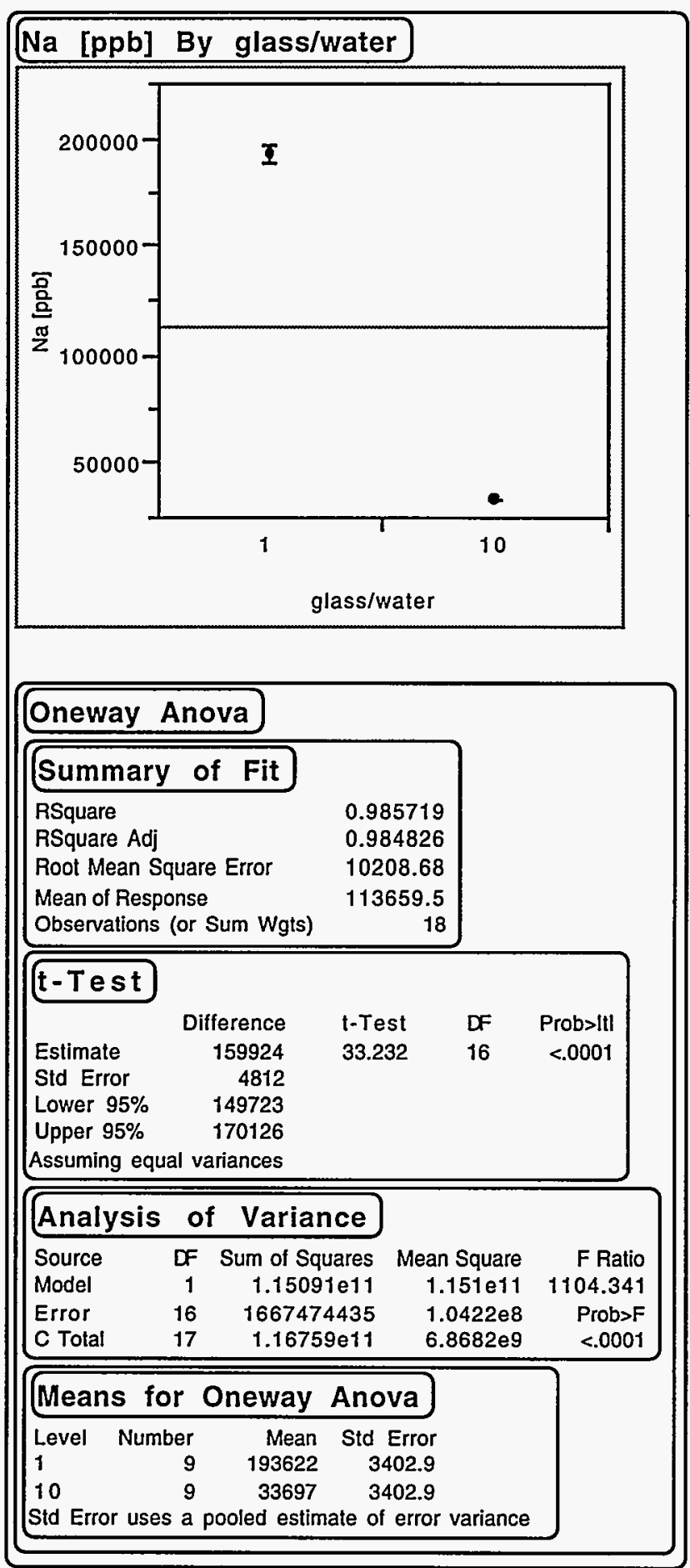


Figure D-3, contd. One-Way ANOVA for Si Concentration in Leachates from 3-day, $70^{\circ} \mathrm{C}, 1: 1$, and 1:10 Tests by Glass/Water Mass Ratio Duration.

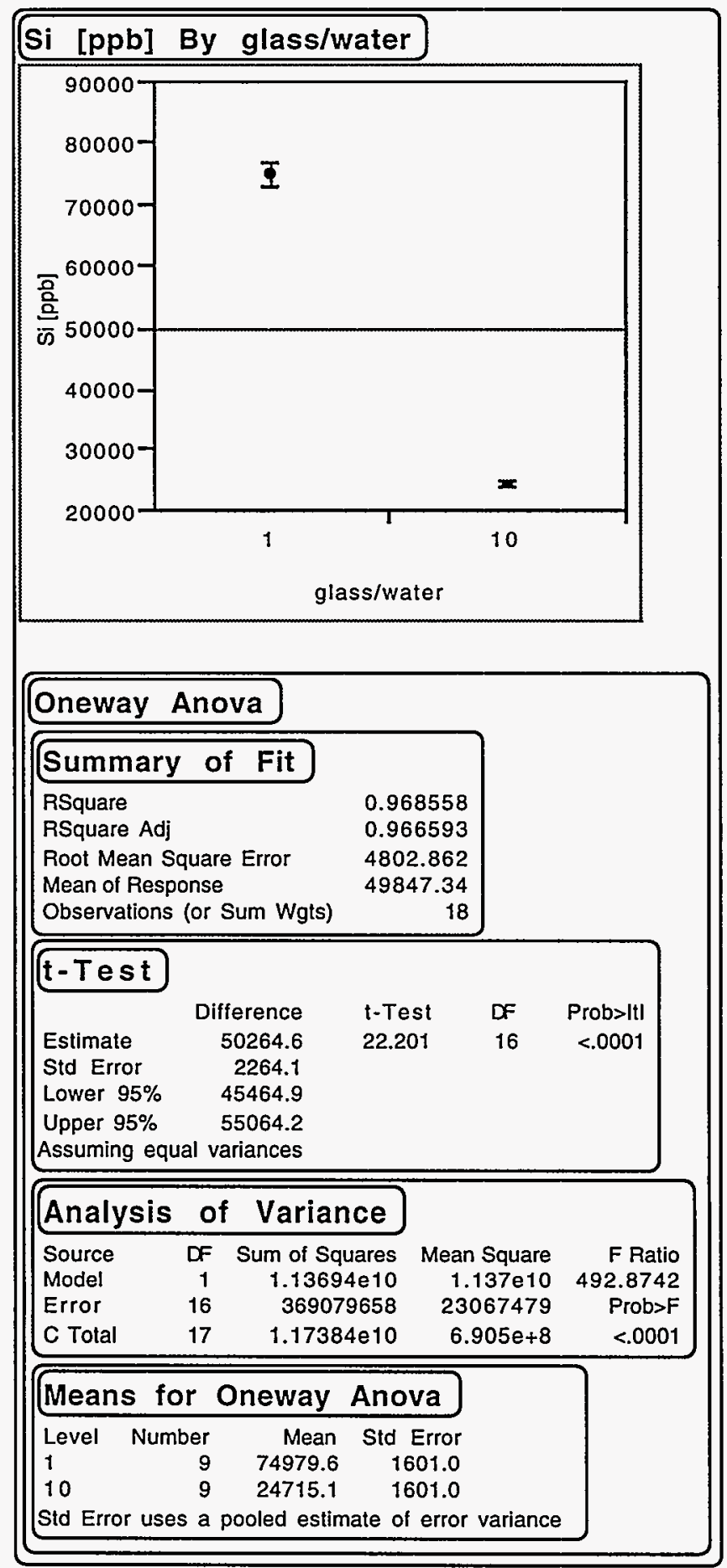


Figure D-3, contd. One-Way ANOVA for B Concentration in Leachates from 3-day, $70^{\circ} \mathrm{C}, 1: 1$, and 1:10 Tests by Glass/Water Mass Ratio Duration.

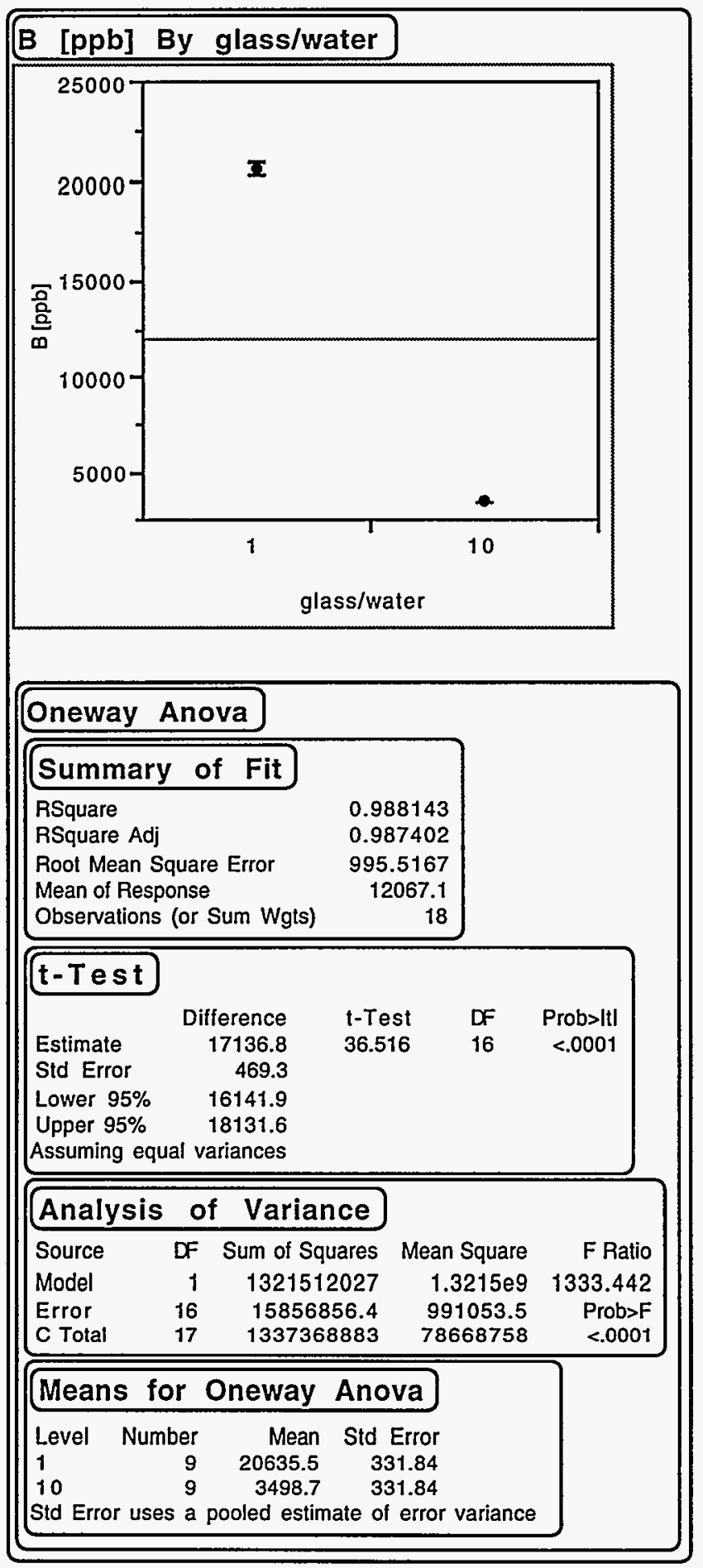


Figure D-4. One-Way ANOVA for Na Concentration in Leachates from 7-day, 20 ${ }^{\circ} \mathrm{C}, 1: 1$, and 1:10 Tests by Glass/Water Mass Ratio Duration.

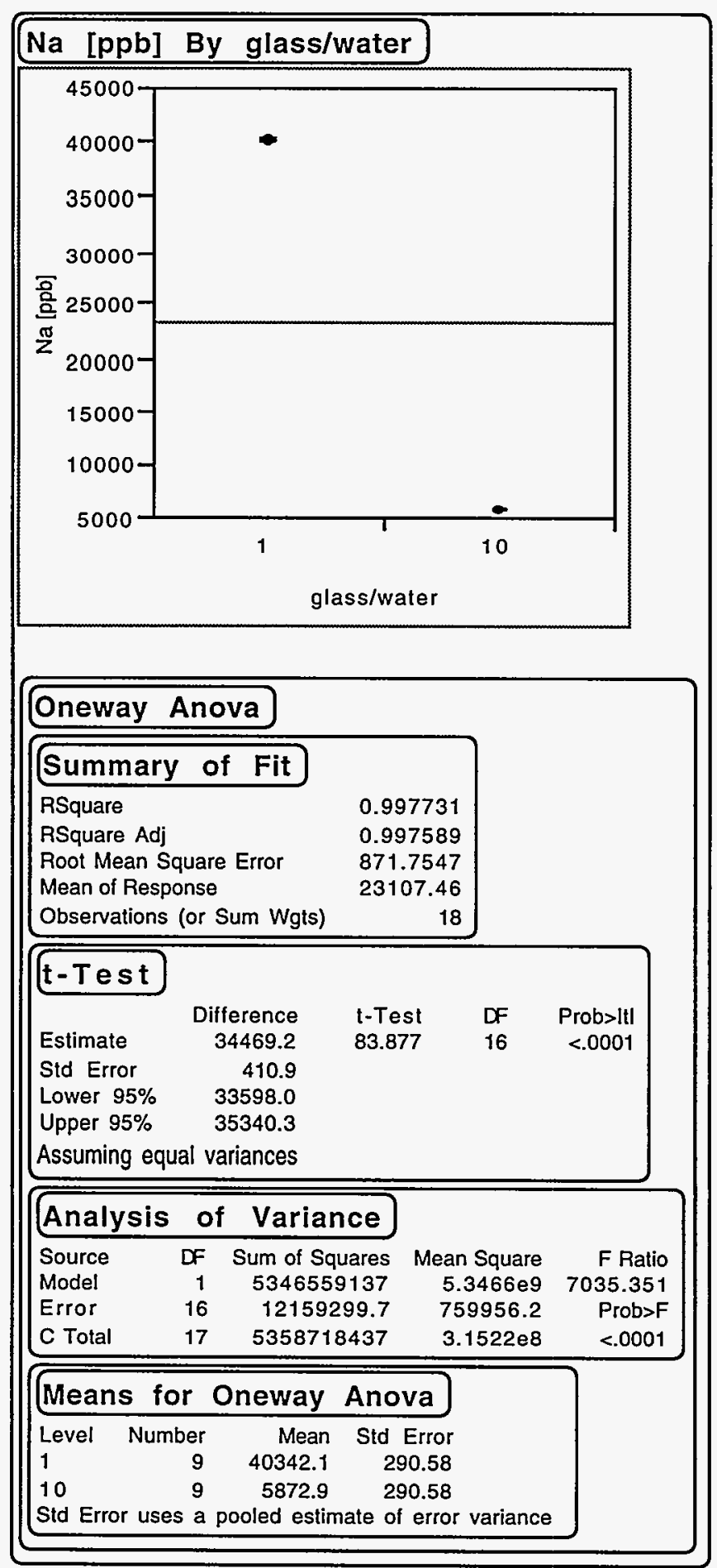


Figure D-4b. One-Way ANOVA for Si Concentration in Leachates from 7-day, $20^{\circ} \mathrm{C}, 1: 1$, and 1:10 Tests by Glass/Water Mass Ratio Duration.

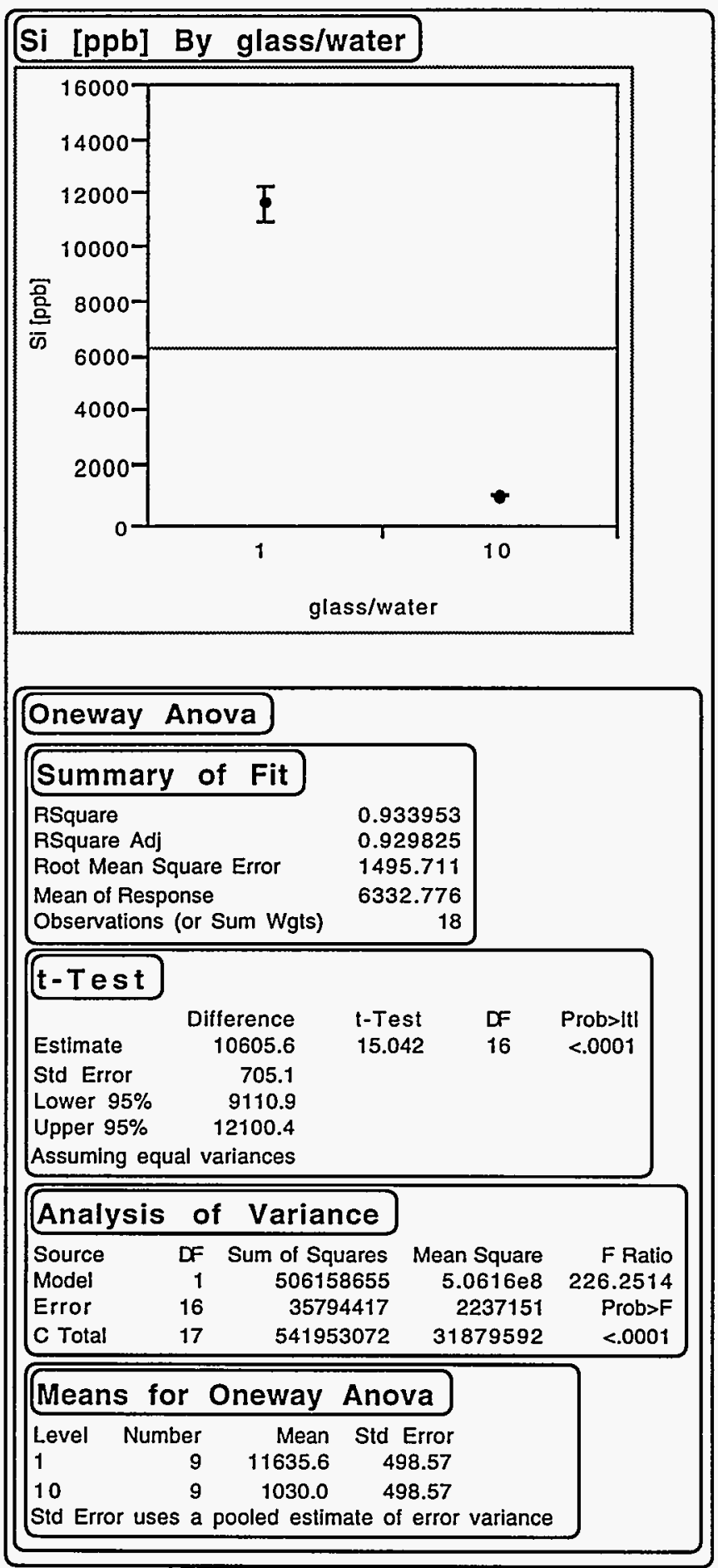


Figure D-4, contd. One-Way ANOVA for B Concentration in Leachates from 7-day, 20 ${ }^{\circ} \mathrm{C}, 1: 1$, and 1:10 Tests by Glass/Water Mass Ratio Duration.

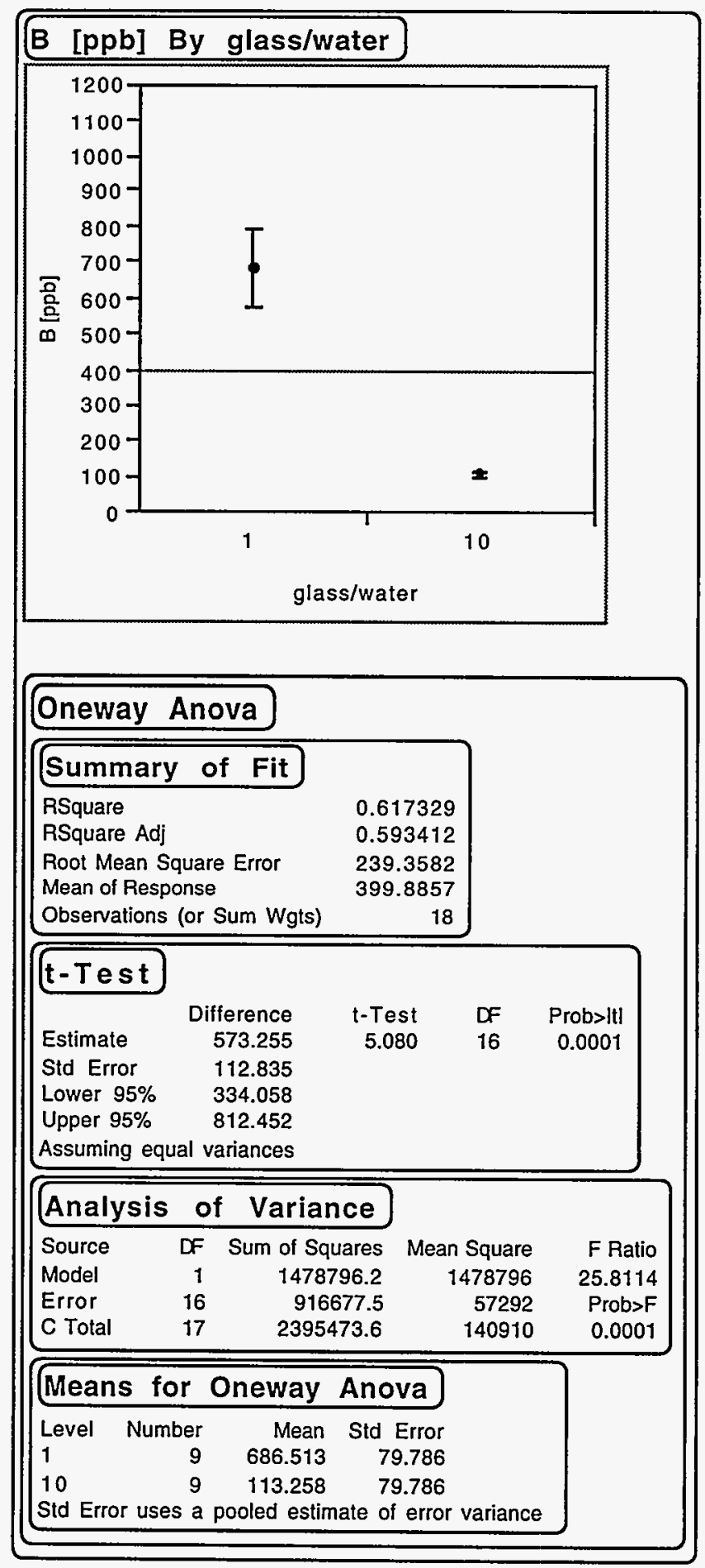


Figure D-5. One-Way ANOVA for Na Concentration in Leachates from 7-day, $40^{\circ} \mathrm{C}, 1: 1$, and 1:10 Tests by Glass/Water Mass Ratio Duration.

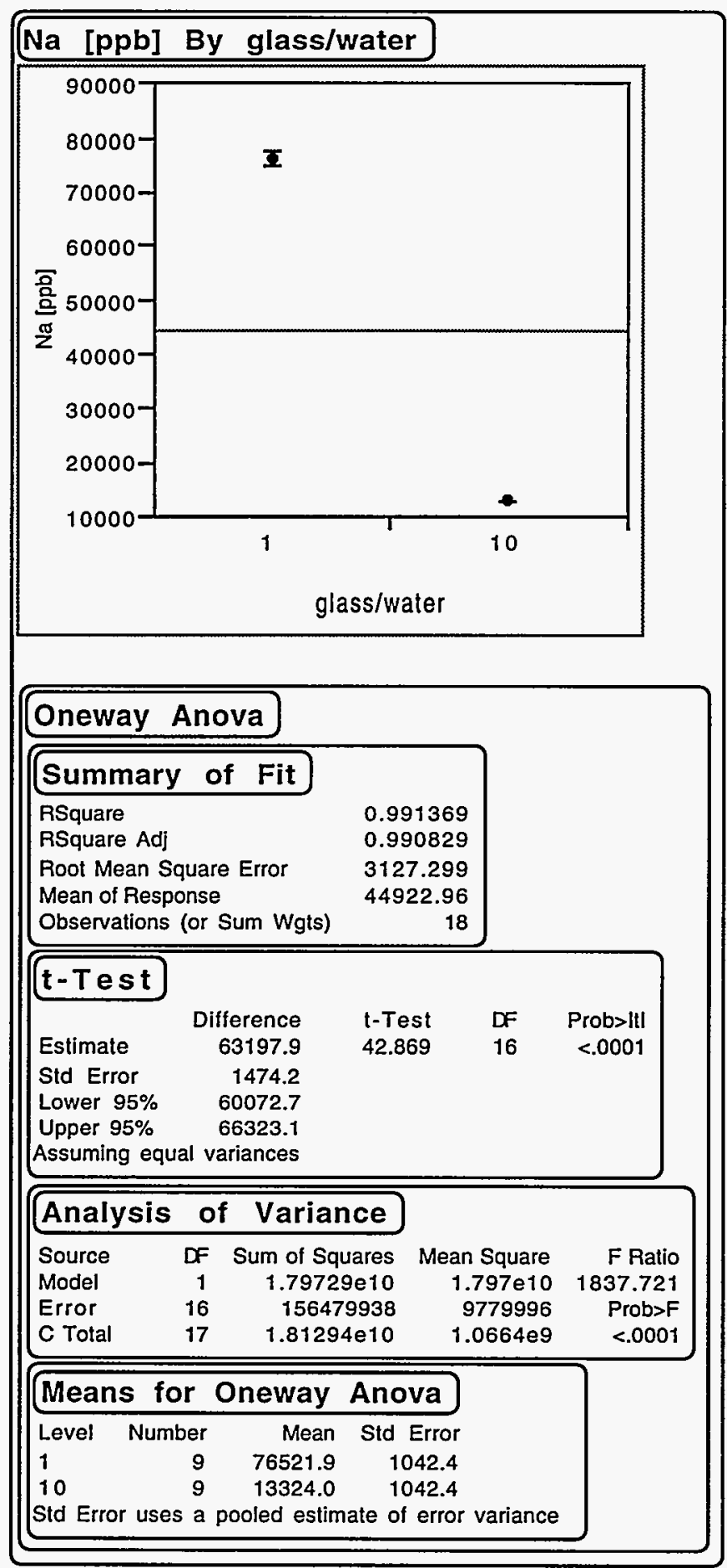


Figure D-5, contd. One-Way ANOVA for Si Concentration in Leachates from 7 -day, $40^{\circ} \mathrm{C}, 1: 1$, and 1:10 Tests by Glass/Water Mass Ratio Duration.

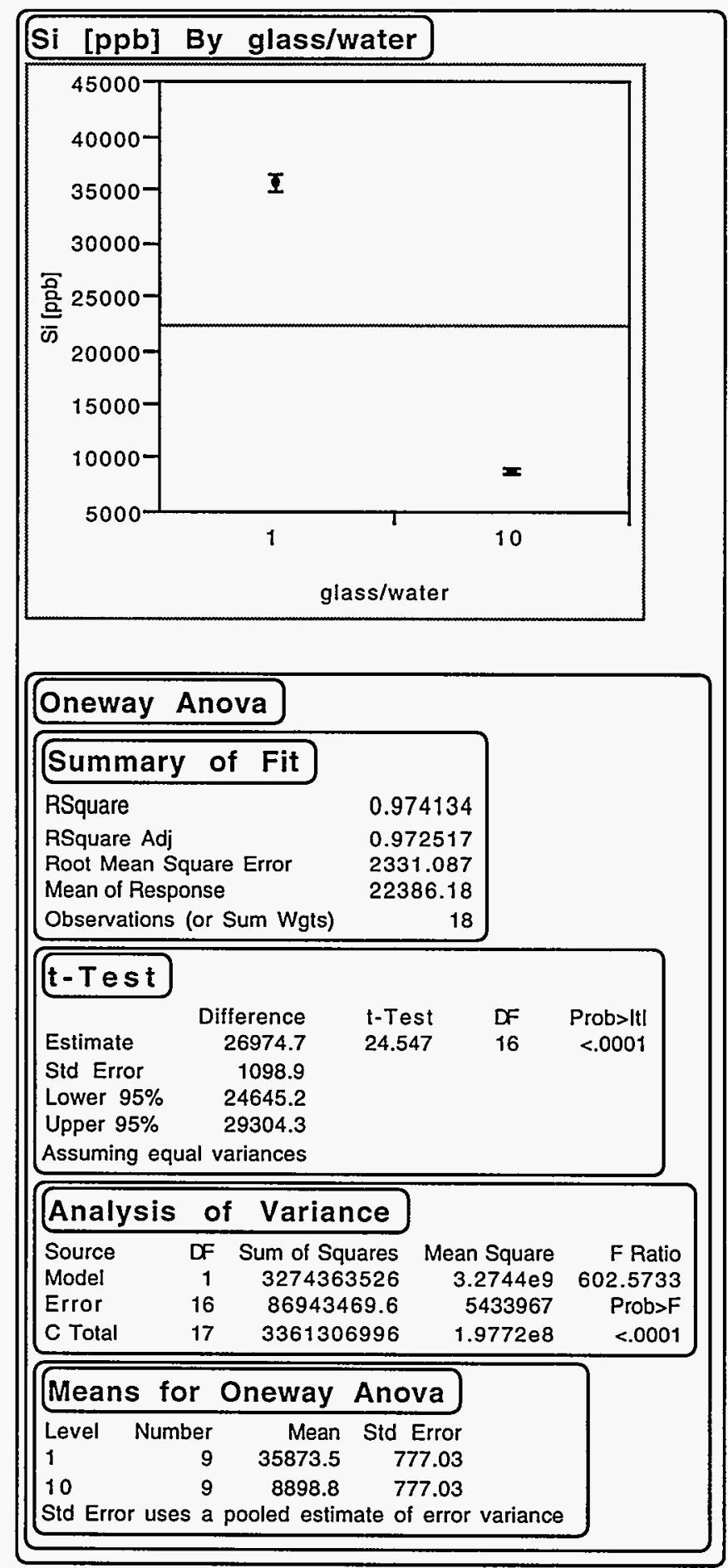


Figure D-5, contd. One-Way ANOVA for B Concentration in Leachates from 7-day, $40^{\circ} \mathrm{C}, 1: 1$, and 1:10 Tests by Glass/Water Mass Ratio Duration.

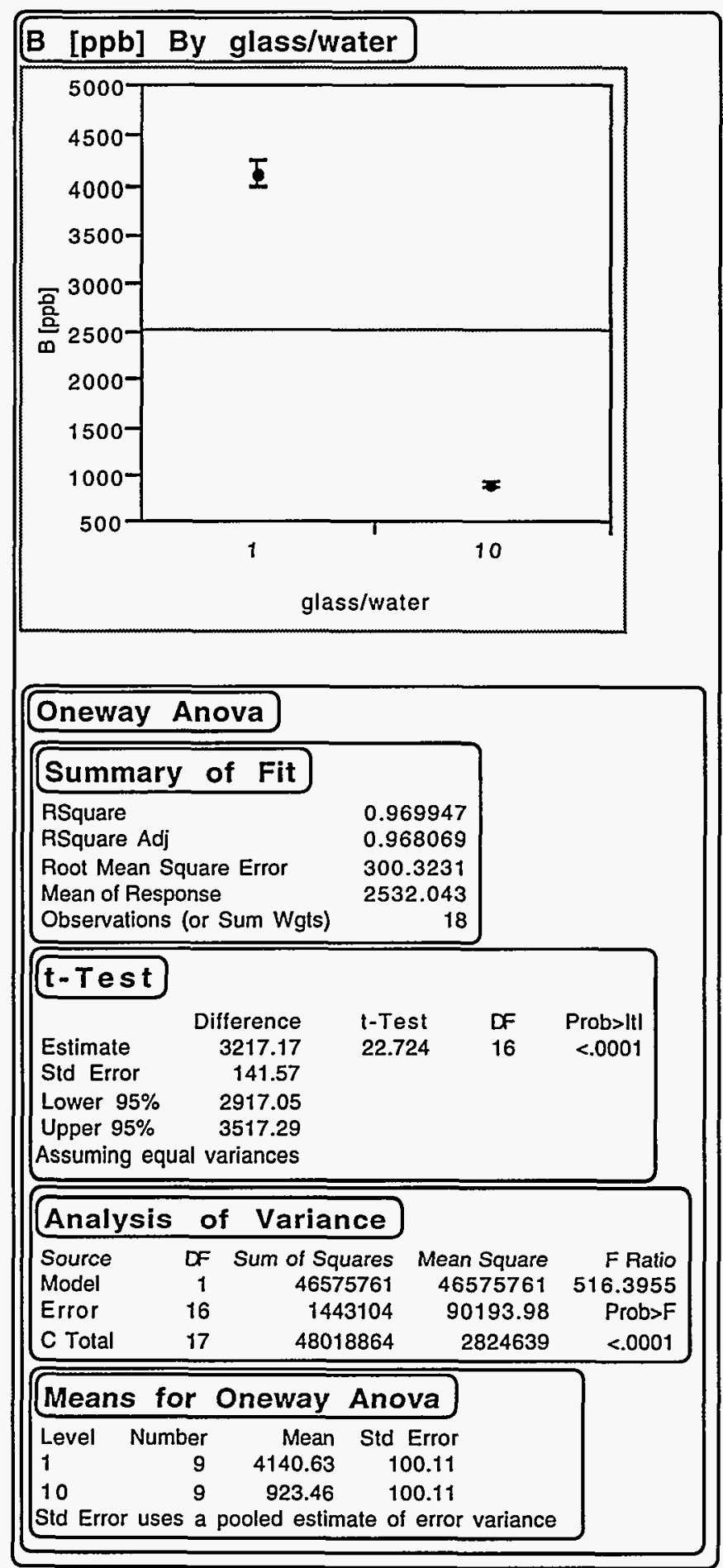


Figure D-6. One-Way ANOVA for Na Concentration in Leachates from 7-day, $70^{\circ} \mathrm{C}, 1: 1$, and 1:10 Tests by Glass/Water Mass Ratio Duration.

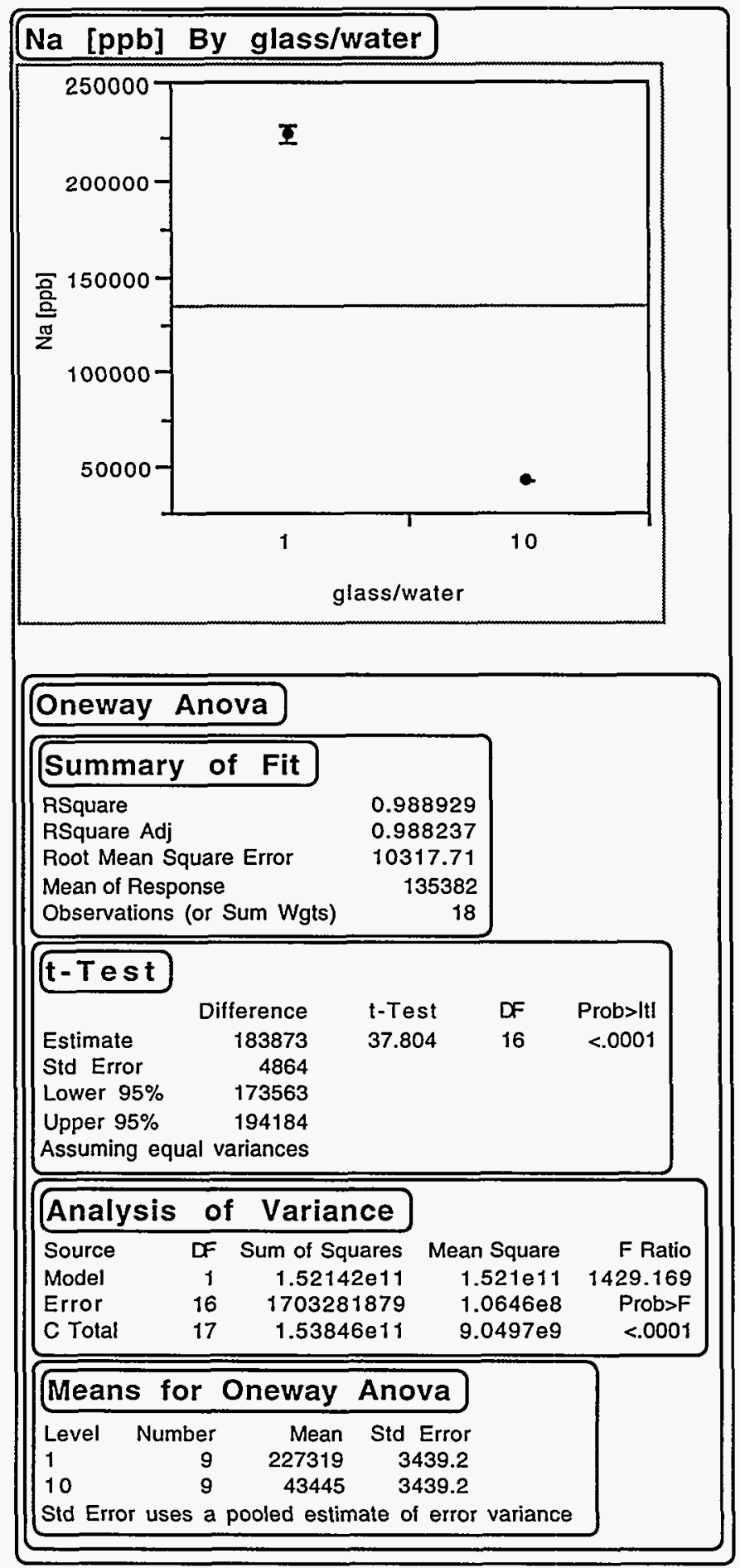


Figure D-6, contd. One-Way ANOVA for Si Concentration in Leachates from 7-day, 70 ${ }^{\circ} \mathrm{C}, 1: 1$, and 1:10 Tests by Glass/Water Mass Ratio Duration.

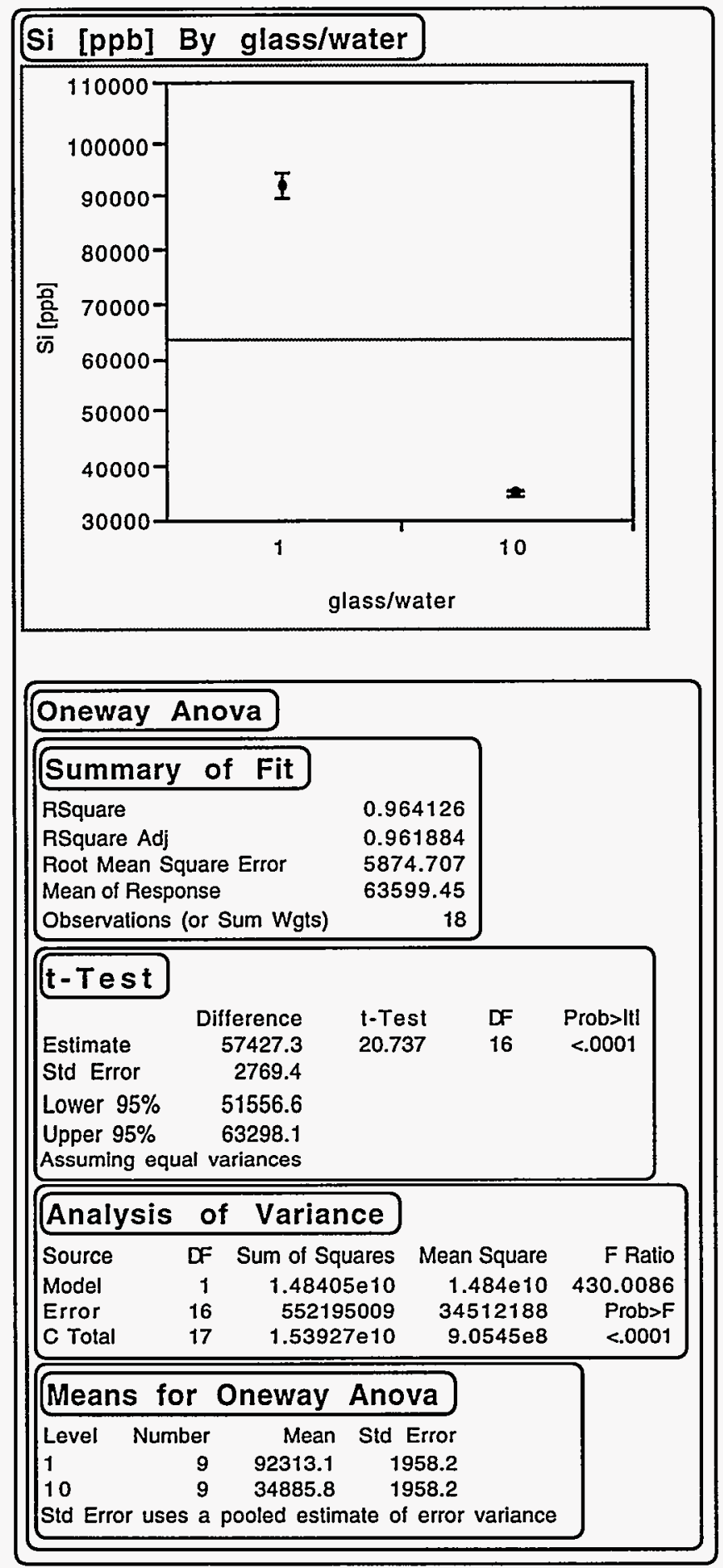


Figure D-6, contd. One-Way ANOVA for B Concentration in Leachates from 7-day, 70 ${ }^{\circ} \mathrm{C}, 1: 1$, and 1:10 Tests by Glass/Water Mass Ratio Duration.

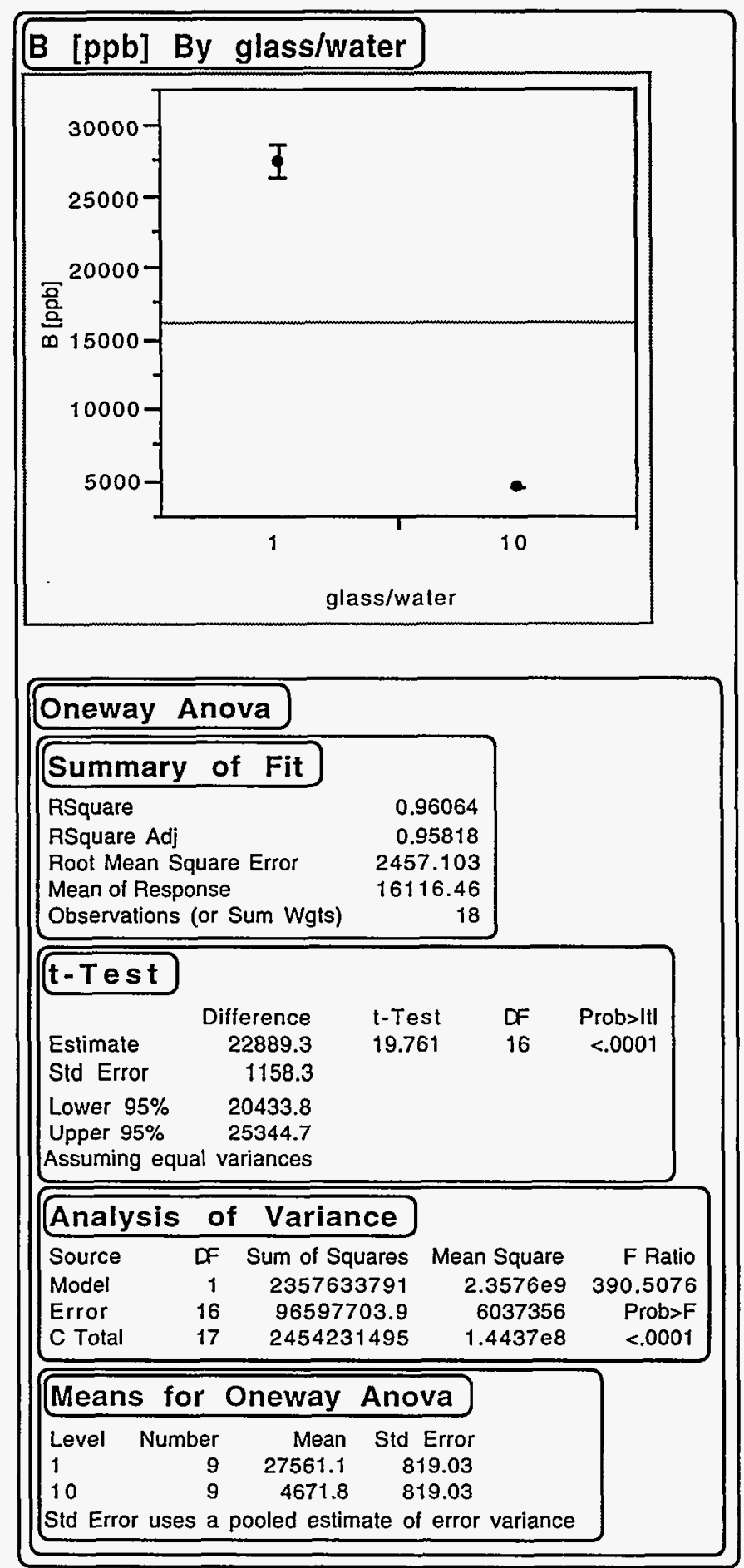




\section{APPENDIX E. ANALYSIS OF VARIANCE BY TEMPERATURE}

Figure E-1. One-Way ANOVA for Na Concentration in Leachates from 1:10, 3-day, 20, 40, and $70^{\circ} \mathrm{C}$ Tests by Test Temperature.

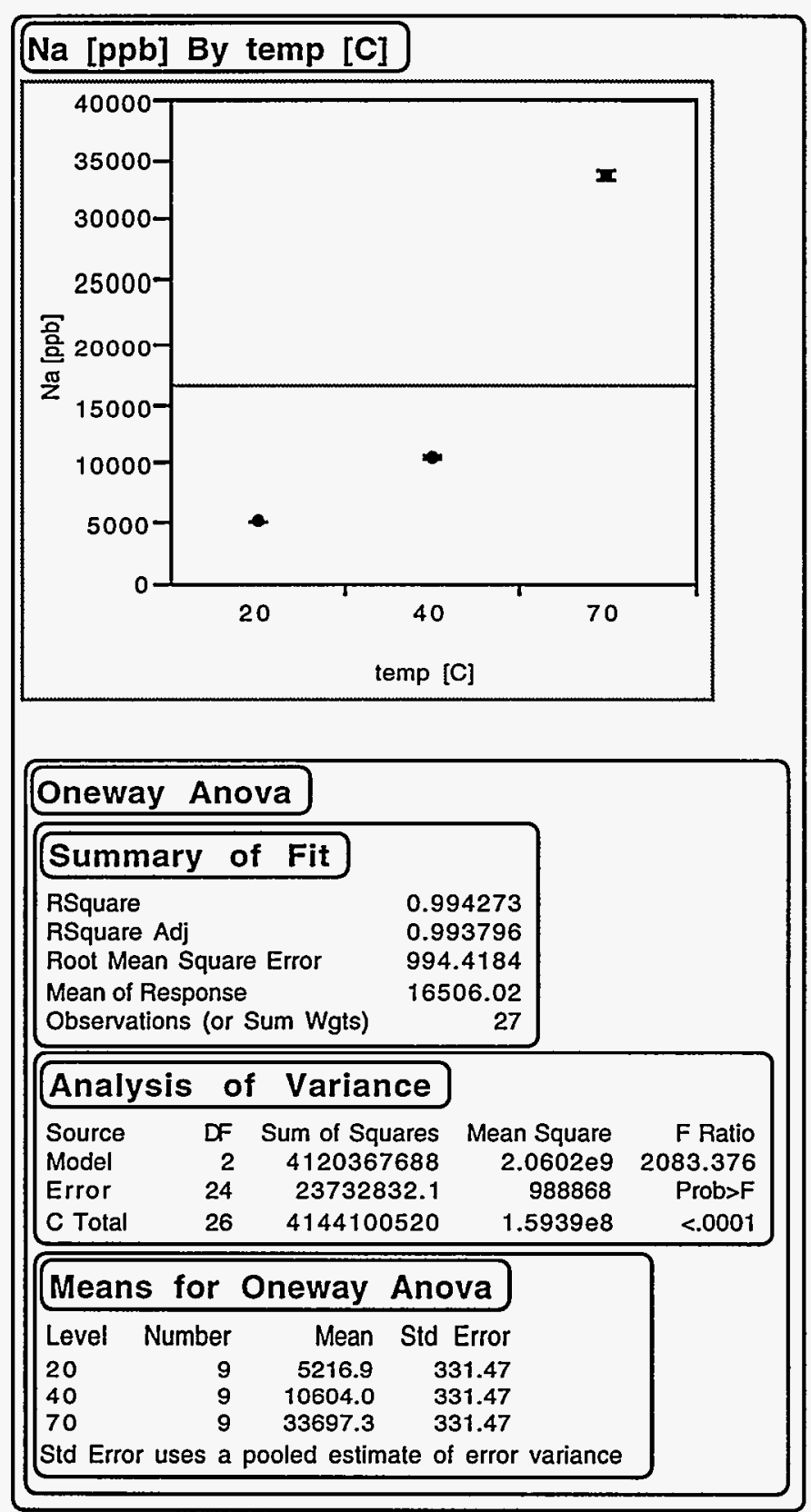


Figure E-1, contd. One-Way ANOVA for Si Concentration in Leachates from 1:10, 3-day, 20, 40 , and $70^{\circ} \mathrm{C}$ Tests by Test Temperature.

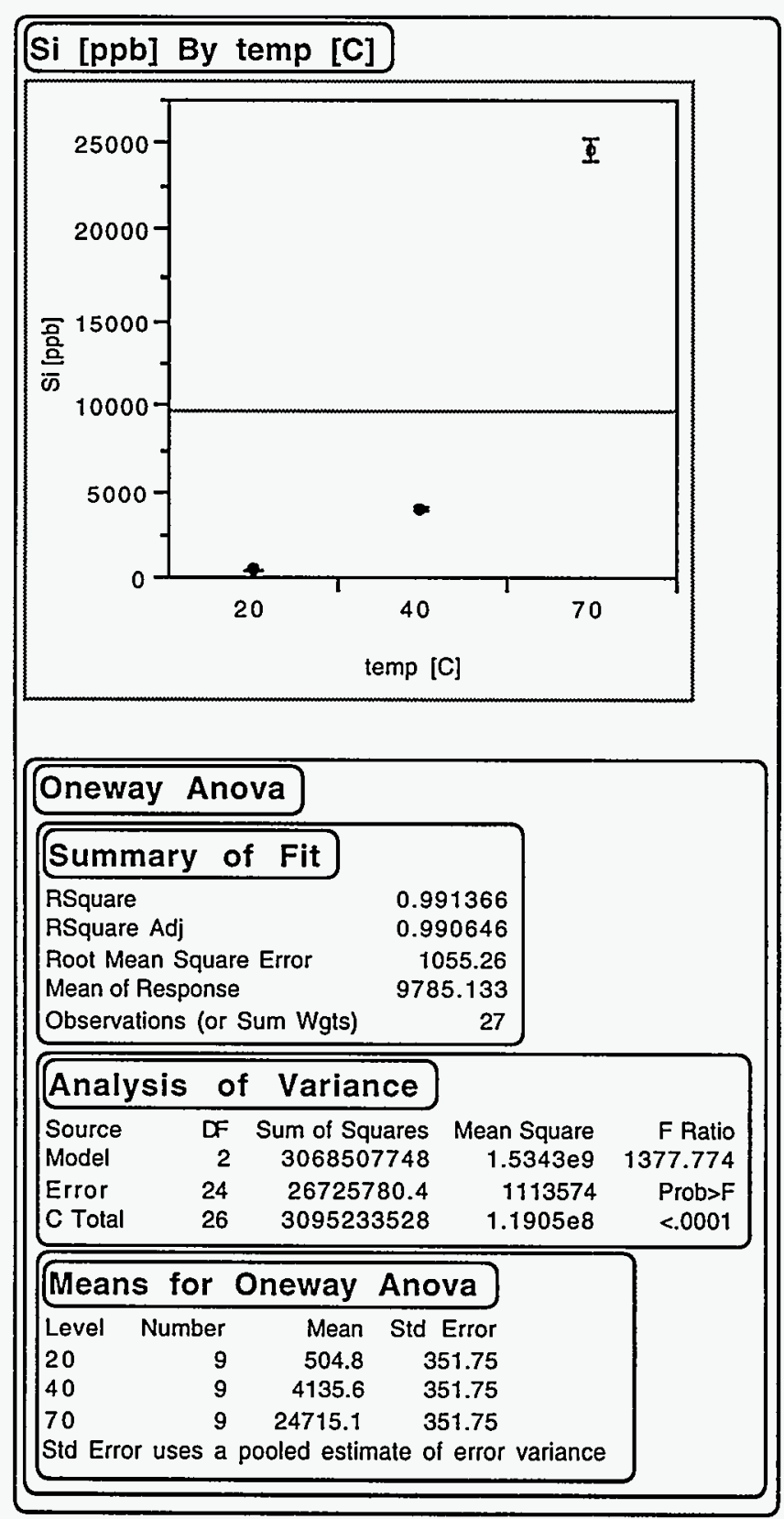


Figure E-1, contd. One-Way ANOVA for B Concentration in Leachates from 1:10, 3-day, 20, 40 , and $70^{\circ} \mathrm{C}$ Tests by Test Temperature.

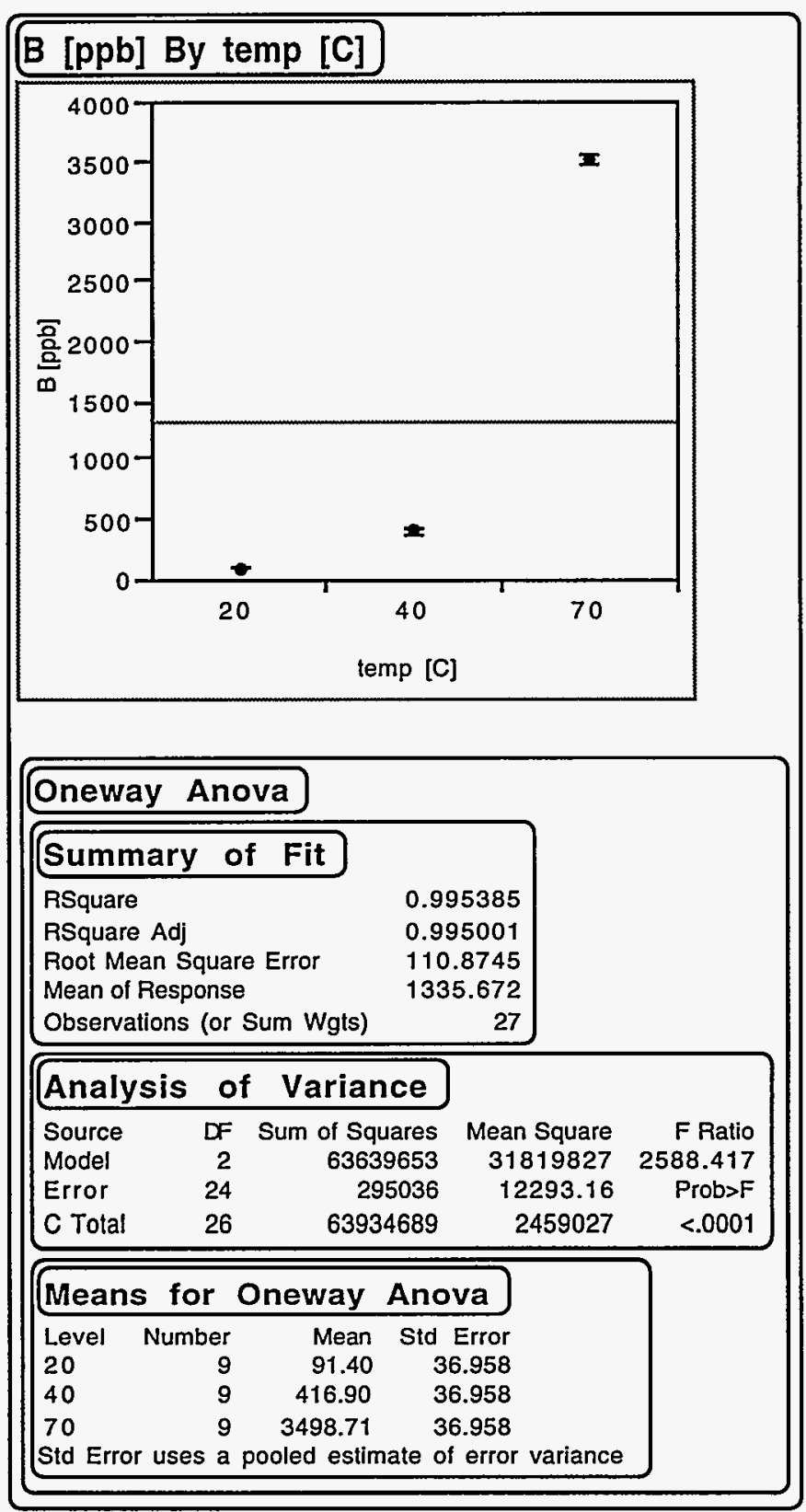


Figure E-2. One-Way ANOVA for Na Concentration in Leachates from 1:1, 3-day, 20, 40, and $70^{\circ} \mathrm{C}$ Tests by Test Temperature.

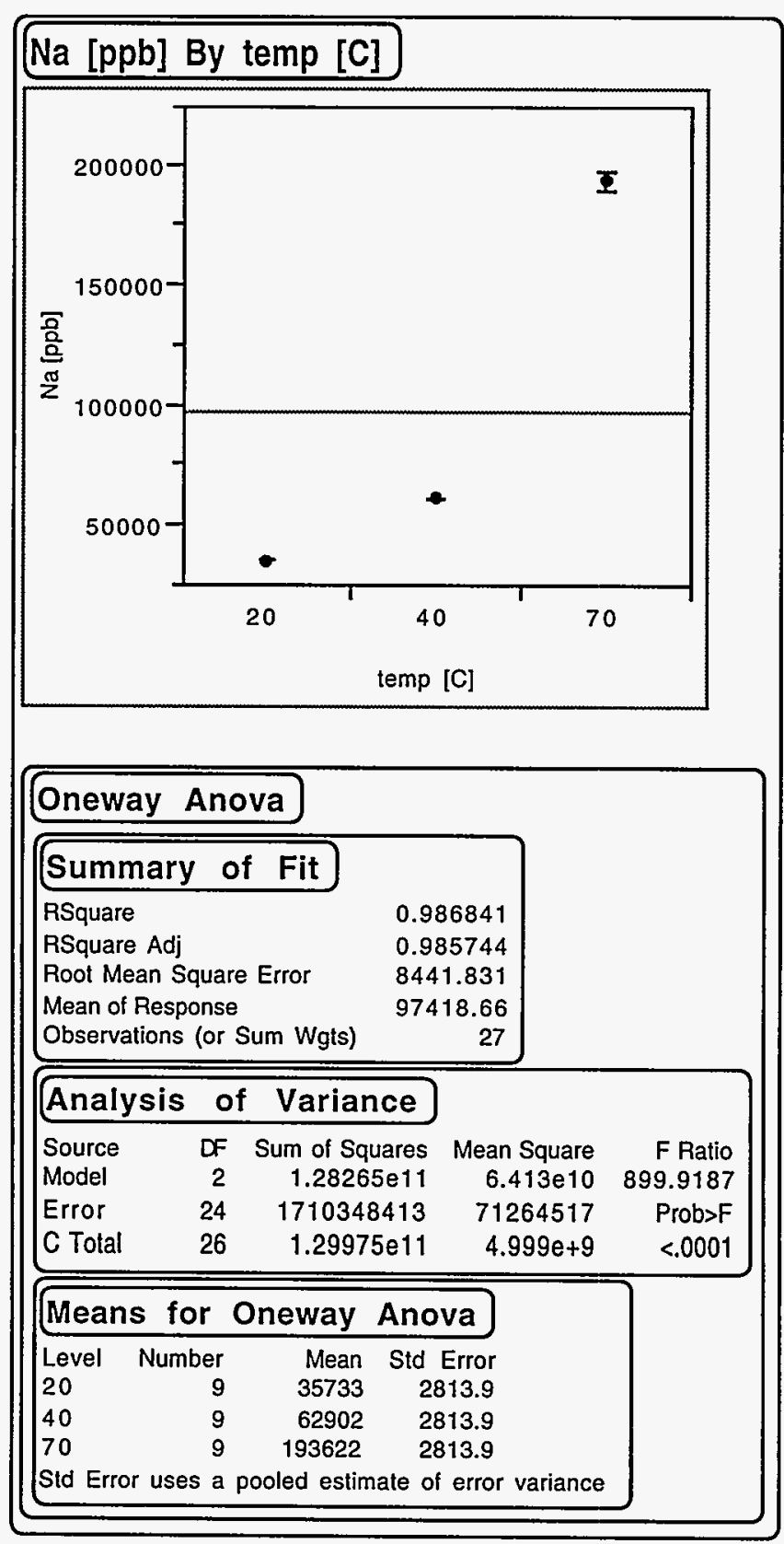


Figure E-2, contd. One-Way ANOVA for Si Concentration in Leachates from 1:1, 3-day, 20, 40, and $70^{\circ} \mathrm{C}$ Tests by Test Temperature.

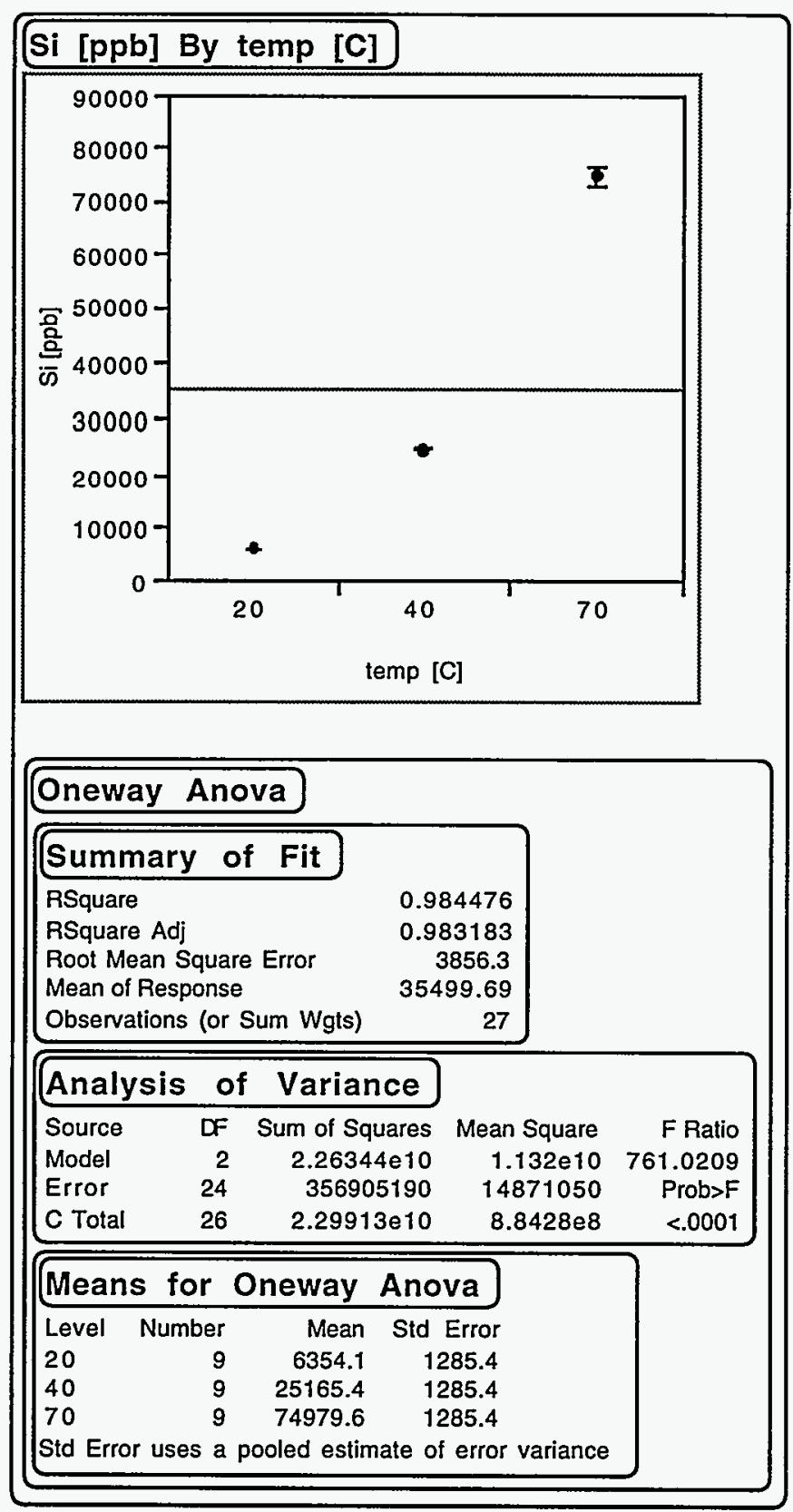


Figure E-2, contd. One-Way ANOVA for B Concentration in Leachates from 1:1, 3-day, 20, 40, and $70^{\circ} \mathrm{C}$ Tests by Test Temperature.

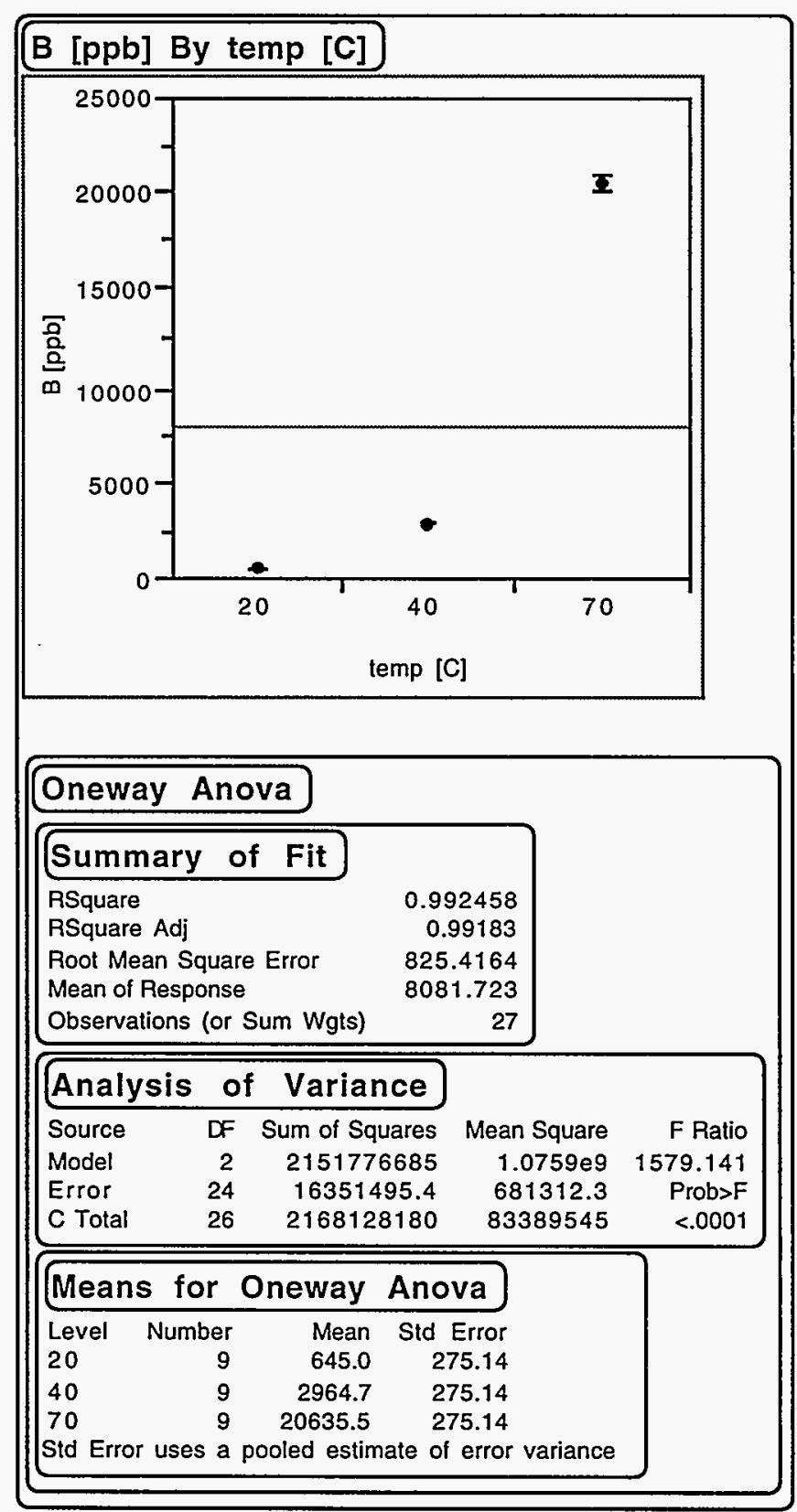


Figure E-3. One-Way ANOVA for Na Concentration in Leachates from 1:10, 7-day, 20, 40, and $70^{\circ} \mathrm{C}$ Tests by Test Temperature.

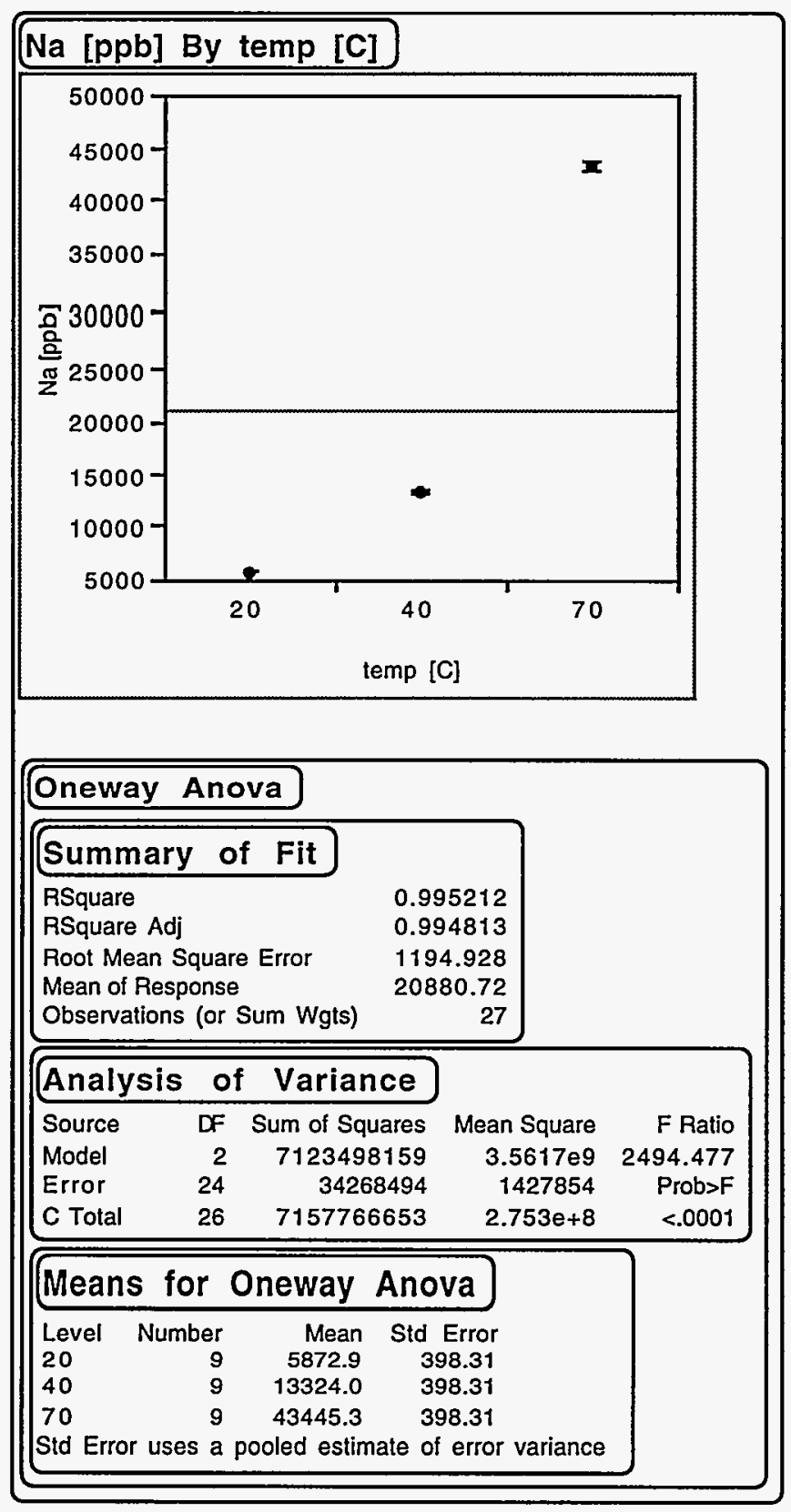


Figure E-3, contd. One-Way ANOVA for Si Concentration in Leachates from 1:10, 7-day, 20, 40 , and $70^{\circ} \mathrm{C}$ Tests by Test Temperature.

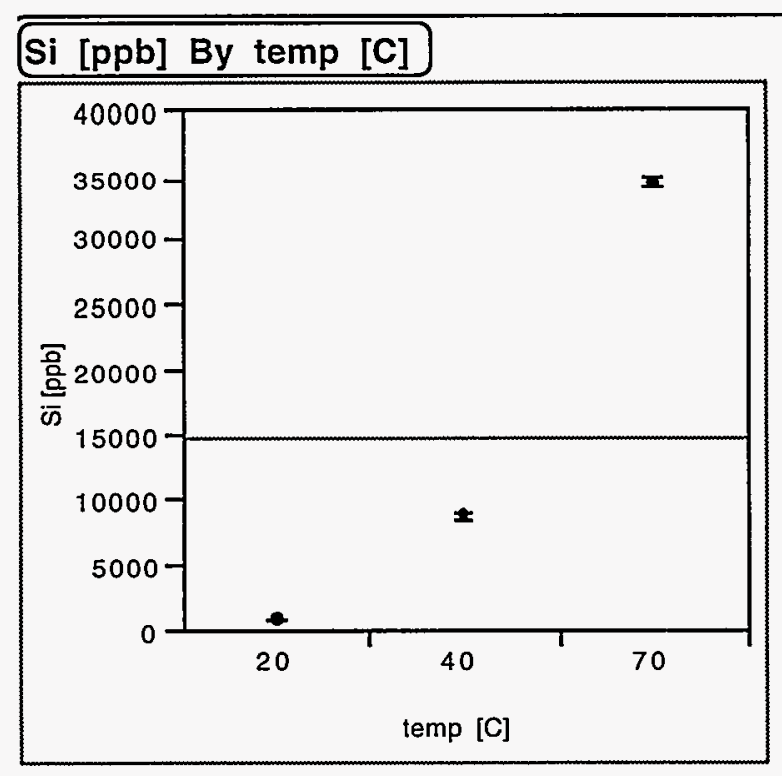

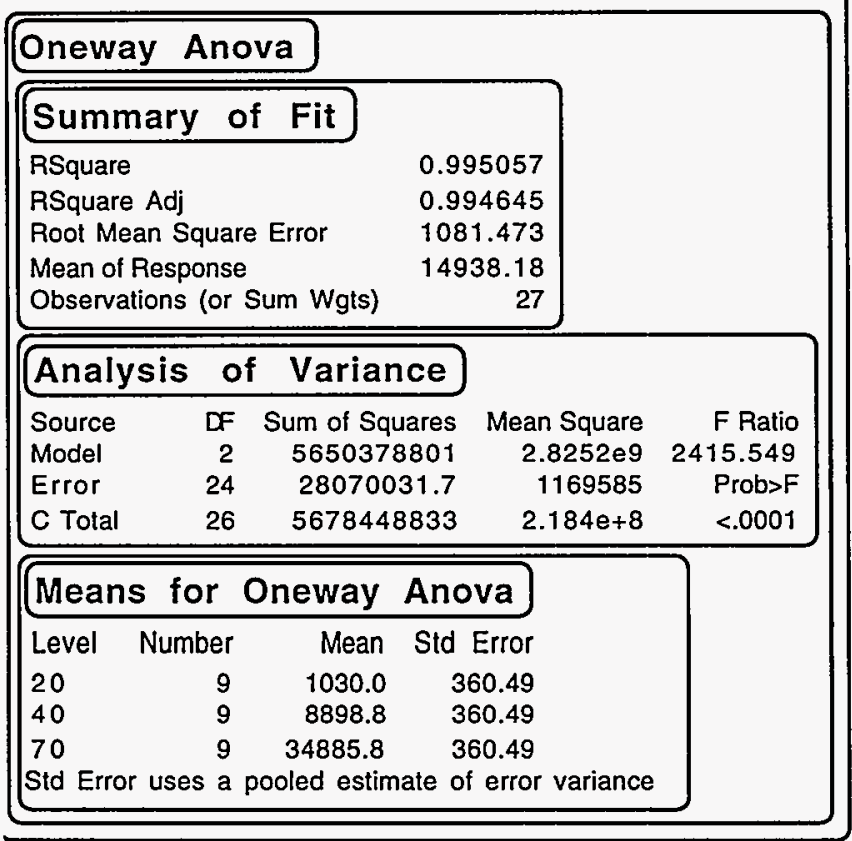


Figure E-3, contd. One-Way ANOVA for B Concentration in Leachates from 1:10, 7-day, 20, 40 , and $70^{\circ} \mathrm{C}$ Tests by Test Temperature.

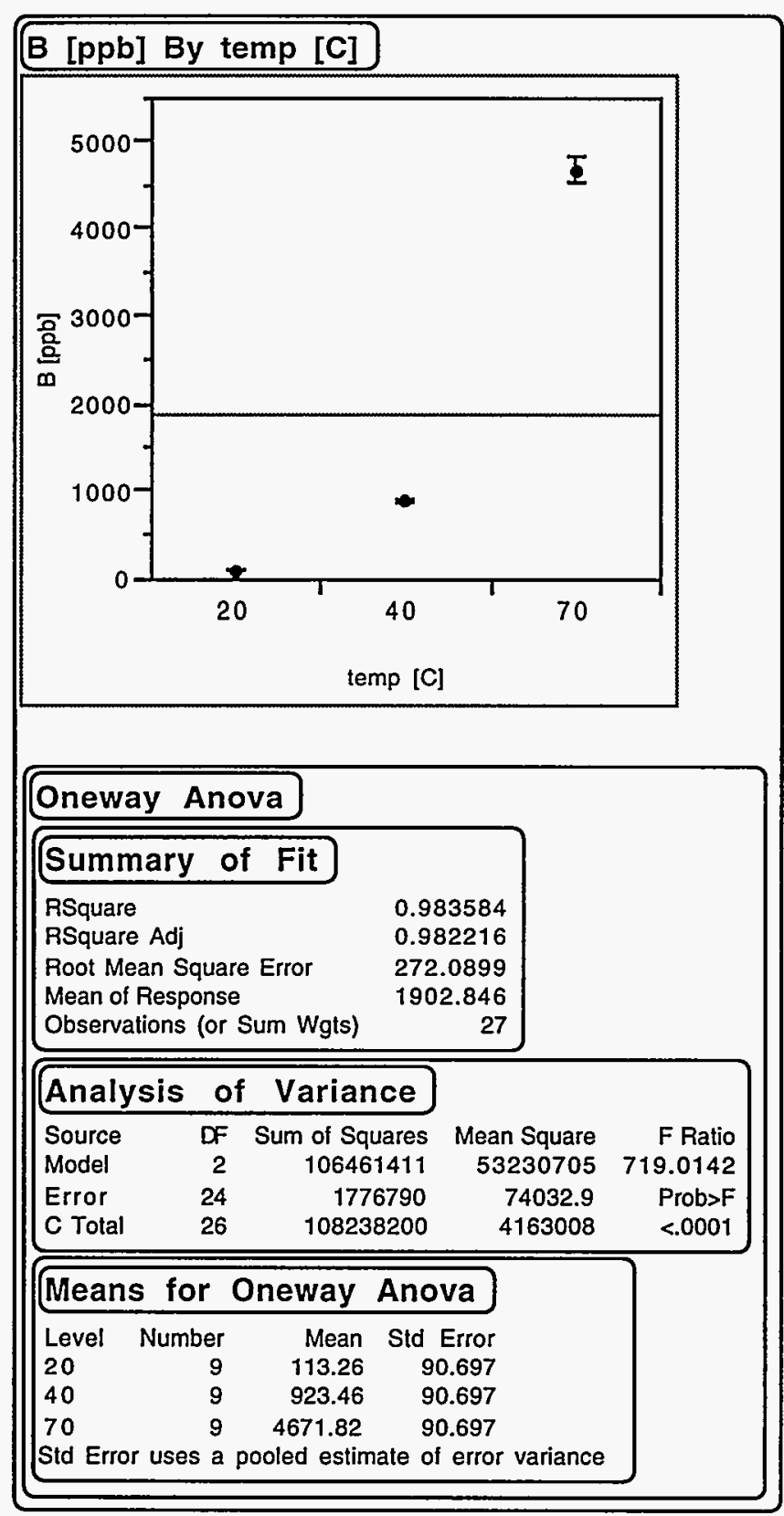


Figure E-4. One-Way ANOVA for Na Concentration in Leachates from 1:1, 7-day, 20, 40, and $70^{\circ} \mathrm{C}$ Tests by Test Temperature.

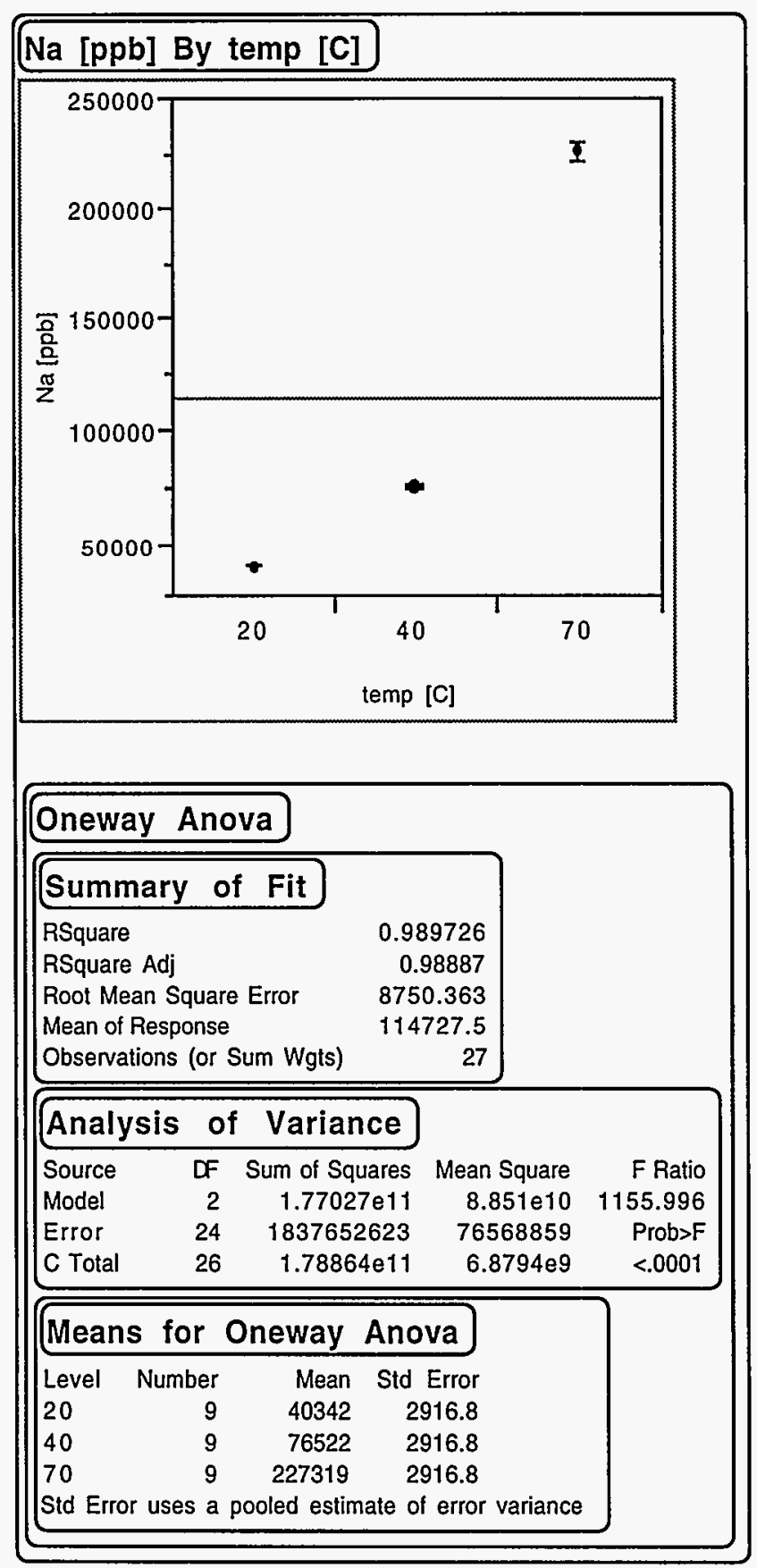


Figure E-4, contd. One-Way ANOVA for Si Concentration in Leachates from 1:1, 7-day, 20, 40, and $70^{\circ} \mathrm{C}$ Tests by Test Temperature.

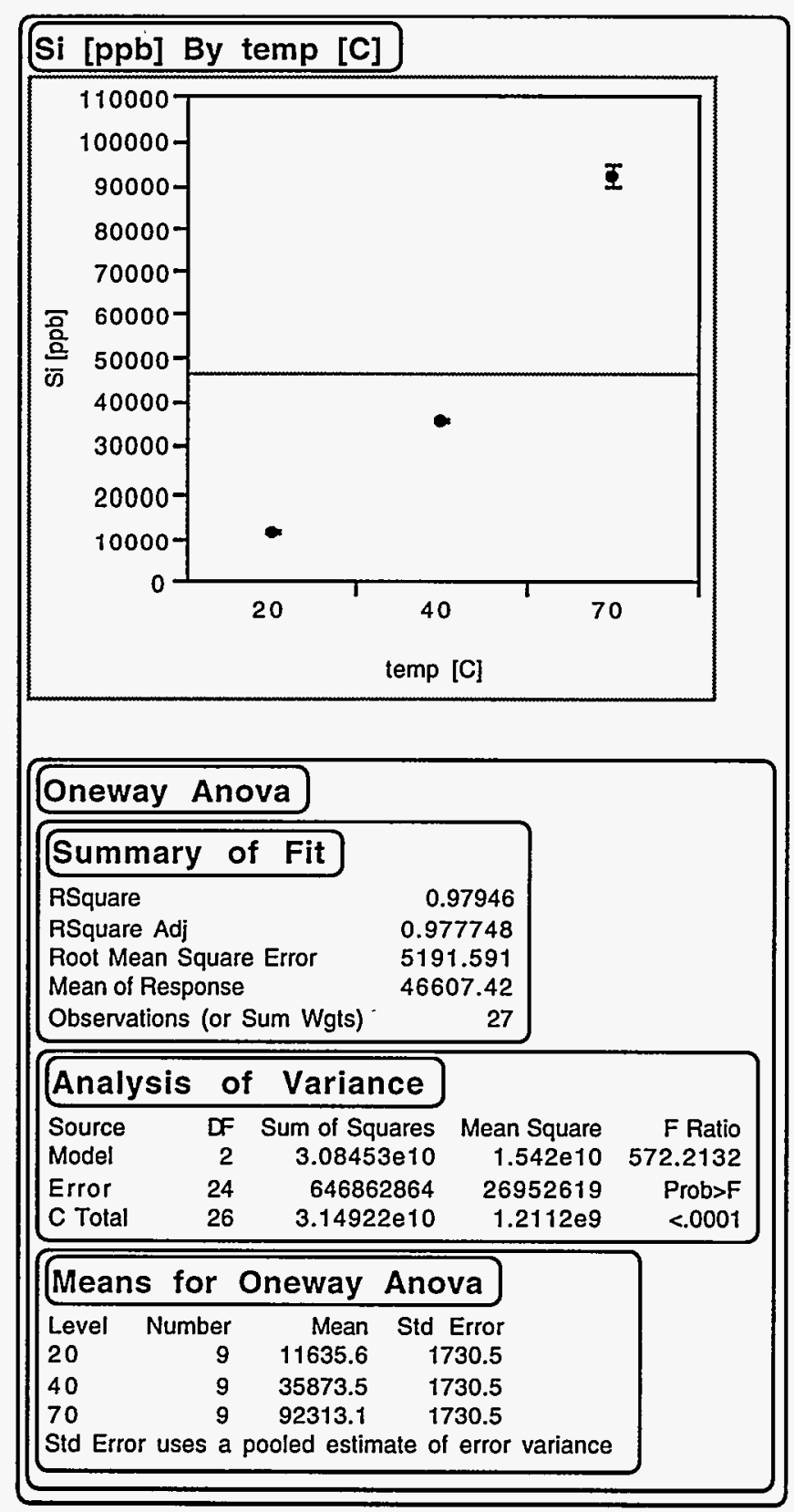


Table E-4, contd. One-Way ANOVA for B Concentration in Leachates from 1:1, 7-day, 20, 40, and $70^{\circ} \mathrm{C}$ Tests by Test Temperature.

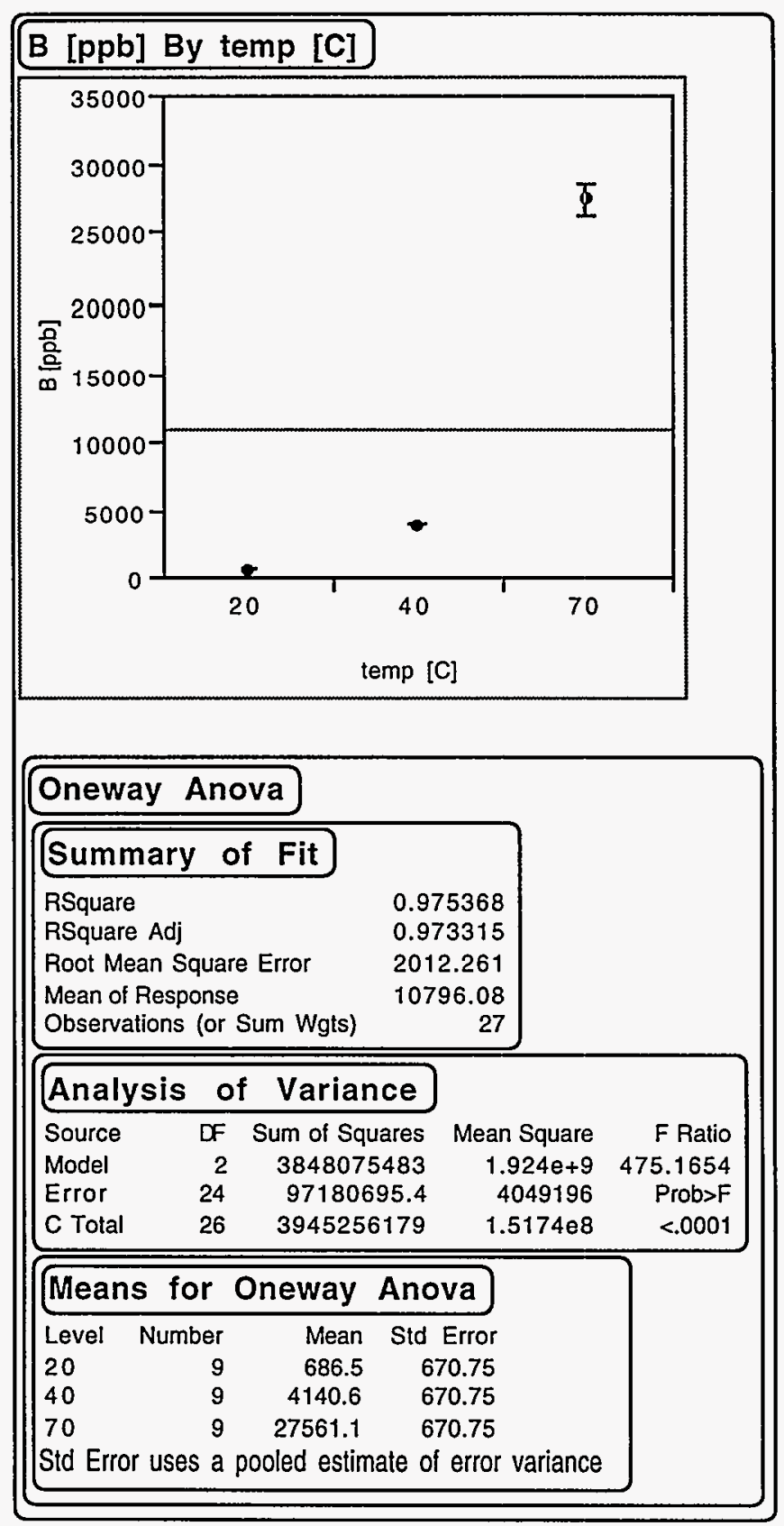




\section{APPENDIX F. ANALYSIS OF VARIANCE BY DURATION}

Figure F-1. One-Way ANOVA for Na Concentration in Leachates from $1: 10,20^{\circ} \mathrm{C}$ Tests by Test Duration.

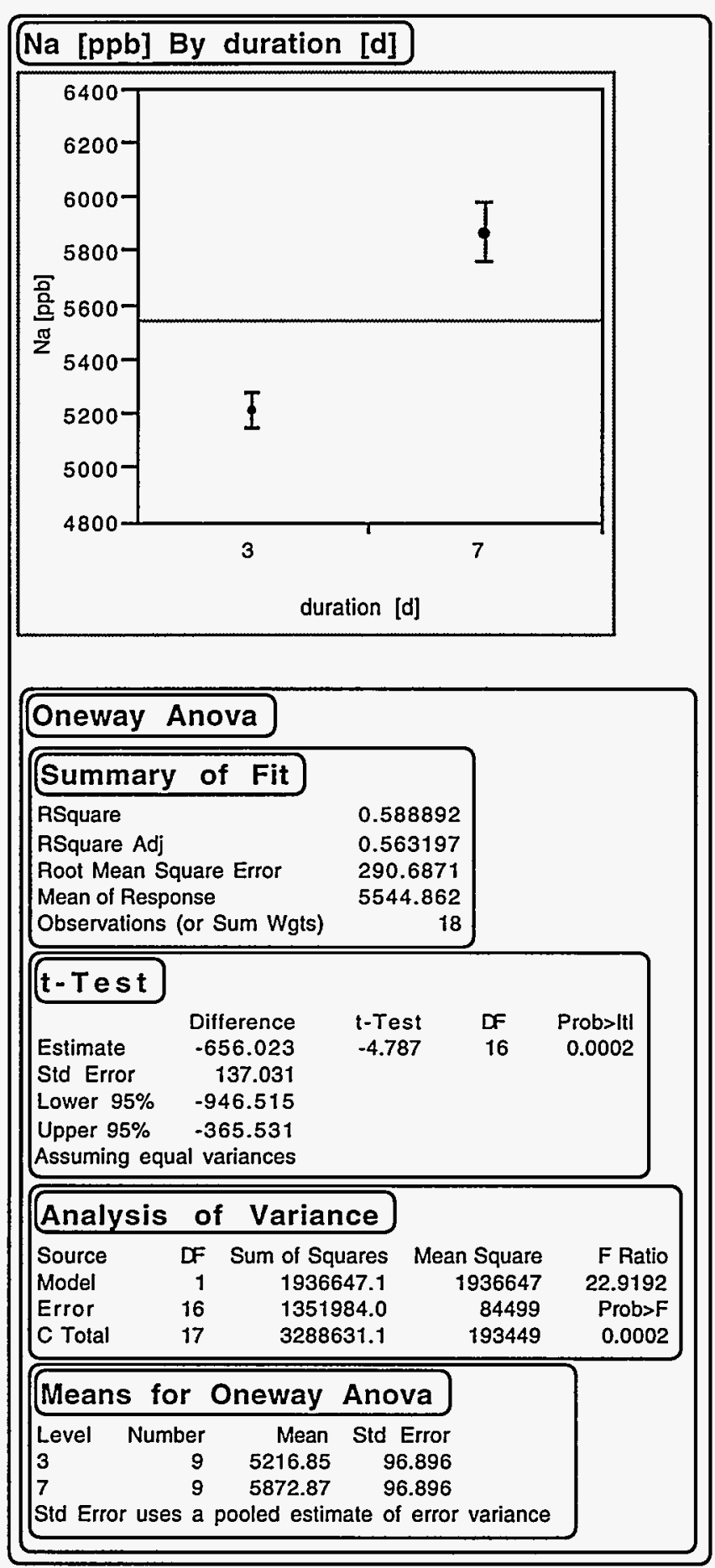


Figure F-1, contd. One-Way ANOVA for Si Concentration in Leachates from 1:10, $20^{\circ} \mathrm{C}$ Tests by Test Duration.

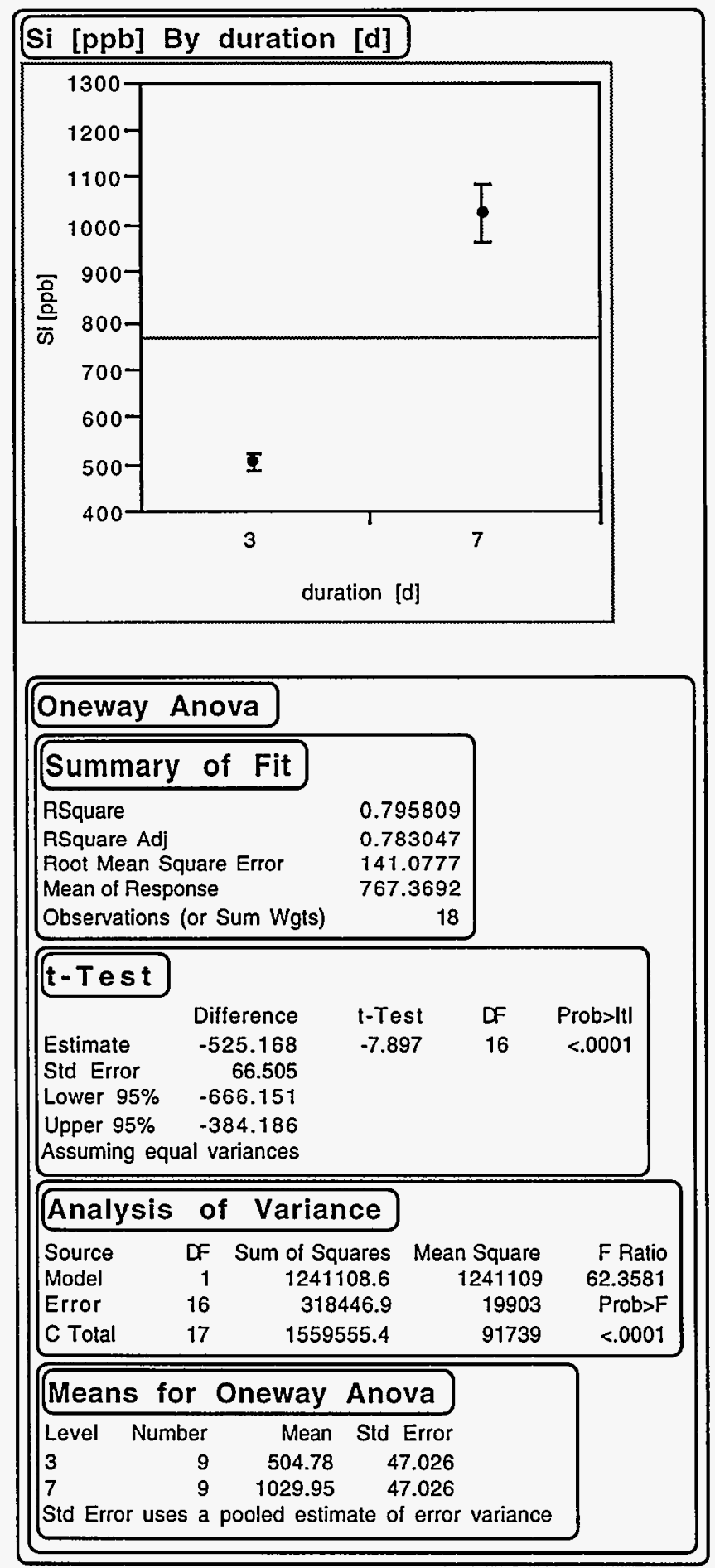


Figure F-1, contd. One-Way ANOVA for B Concentration in Leachates from 1:10, $20^{\circ} \mathrm{C}$ Tests by Test Duration.

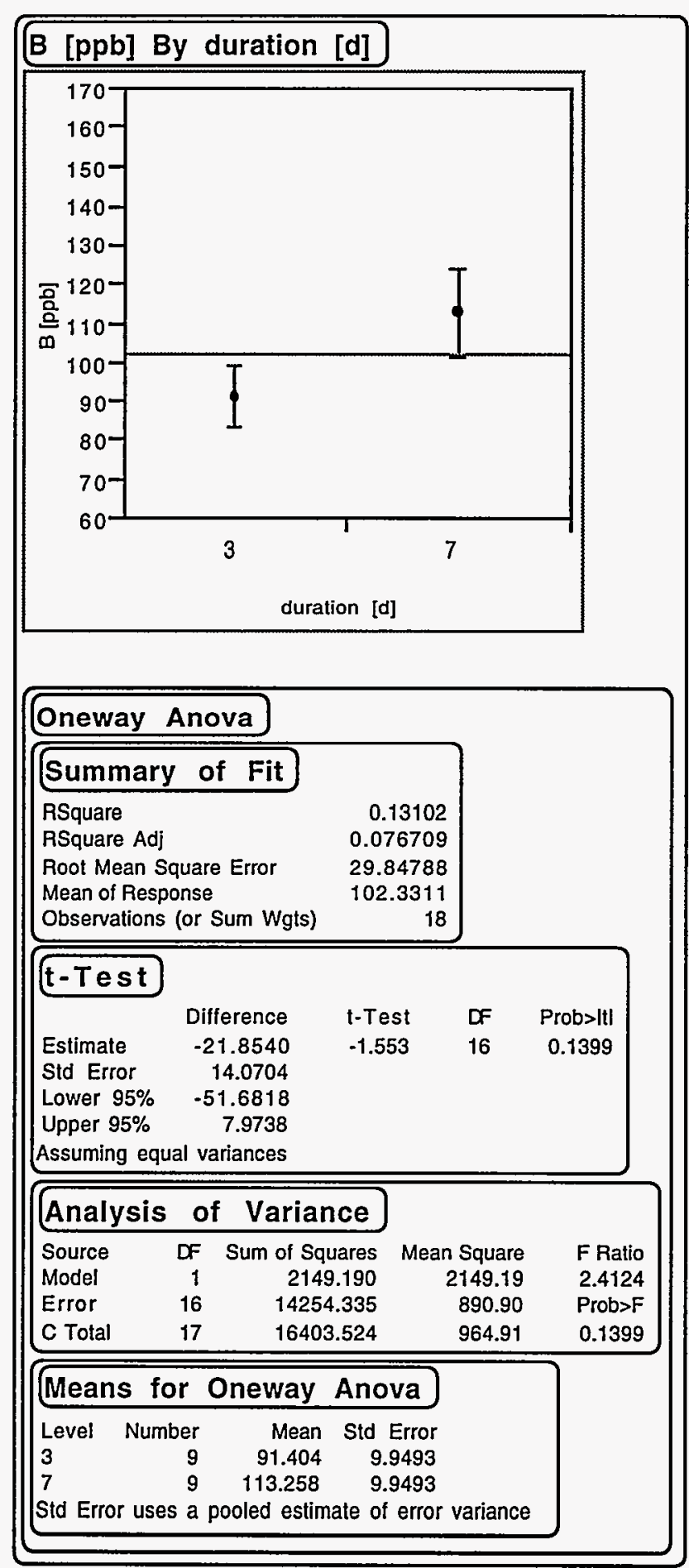


Figure F-2. One-Way ANOVA for Na Concentration in Leachates from $1: 10,40^{\circ} \mathrm{C}$ Tests by Test Duration.

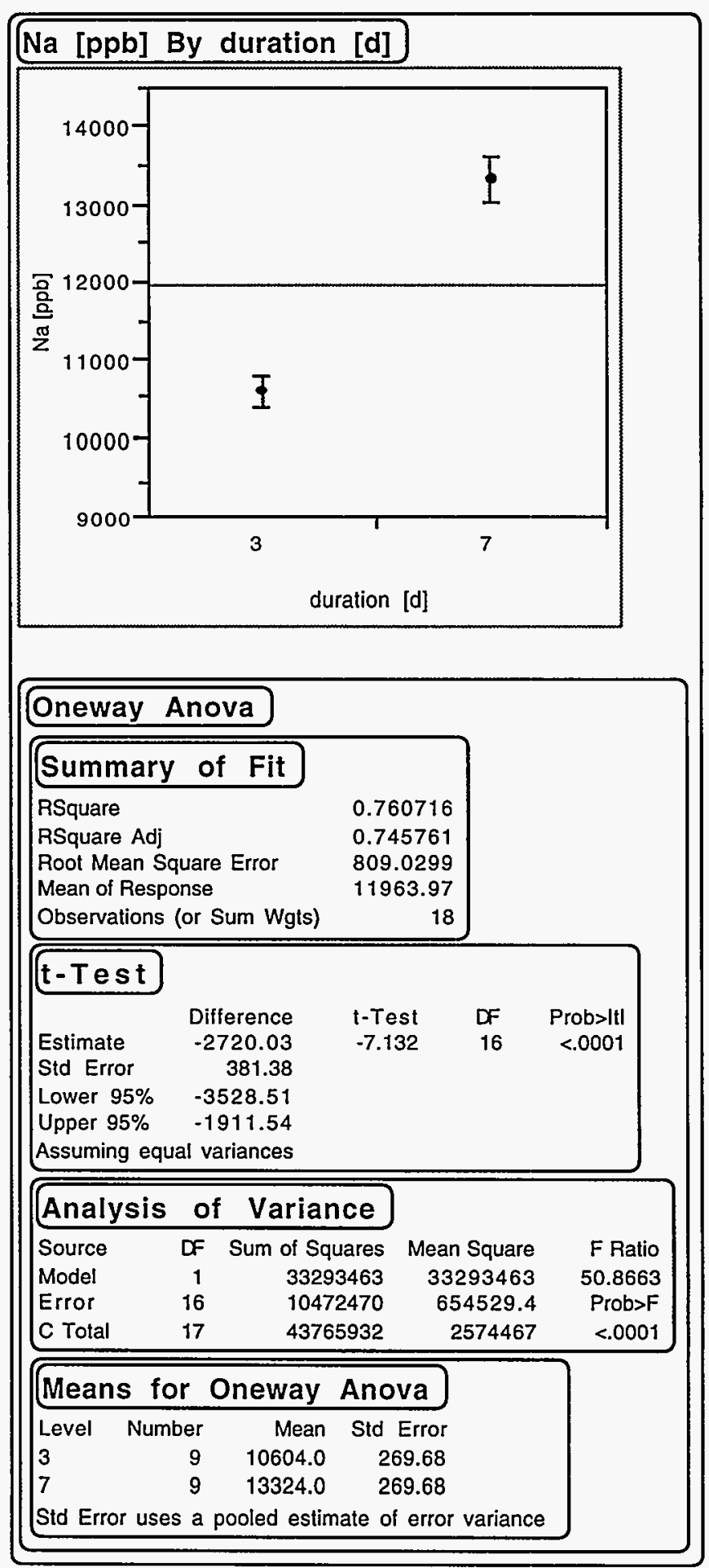


Figure 2, contd. One-Way ANOVA for Si Concentration in Leachates from 1:10, $40^{\circ} \mathrm{C}$ Tests by Test Duration.

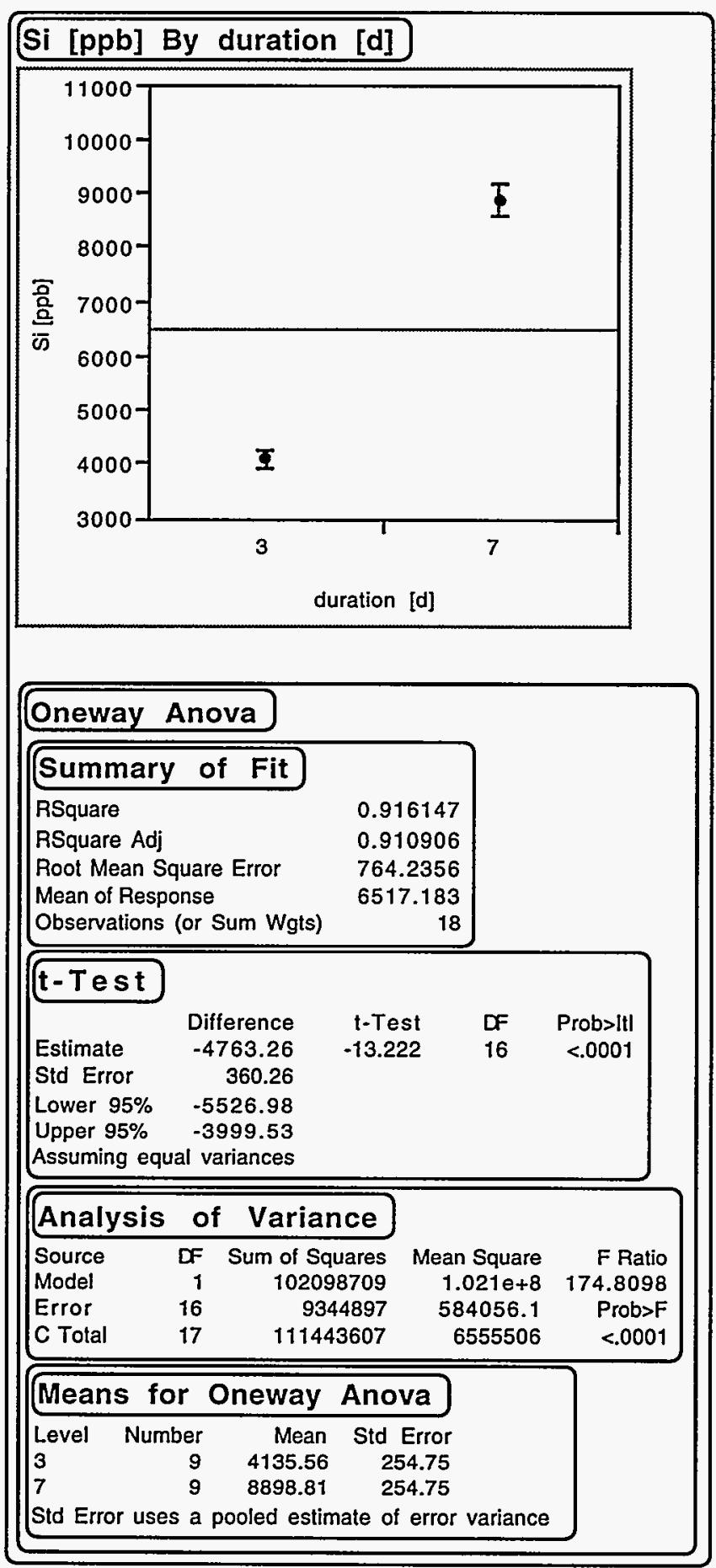


Figure F-2, contd. One-Way ANOVA for B Concentration in Leachates from 1:10, $40^{\circ} \mathrm{C}$ Tests by Test Duration.

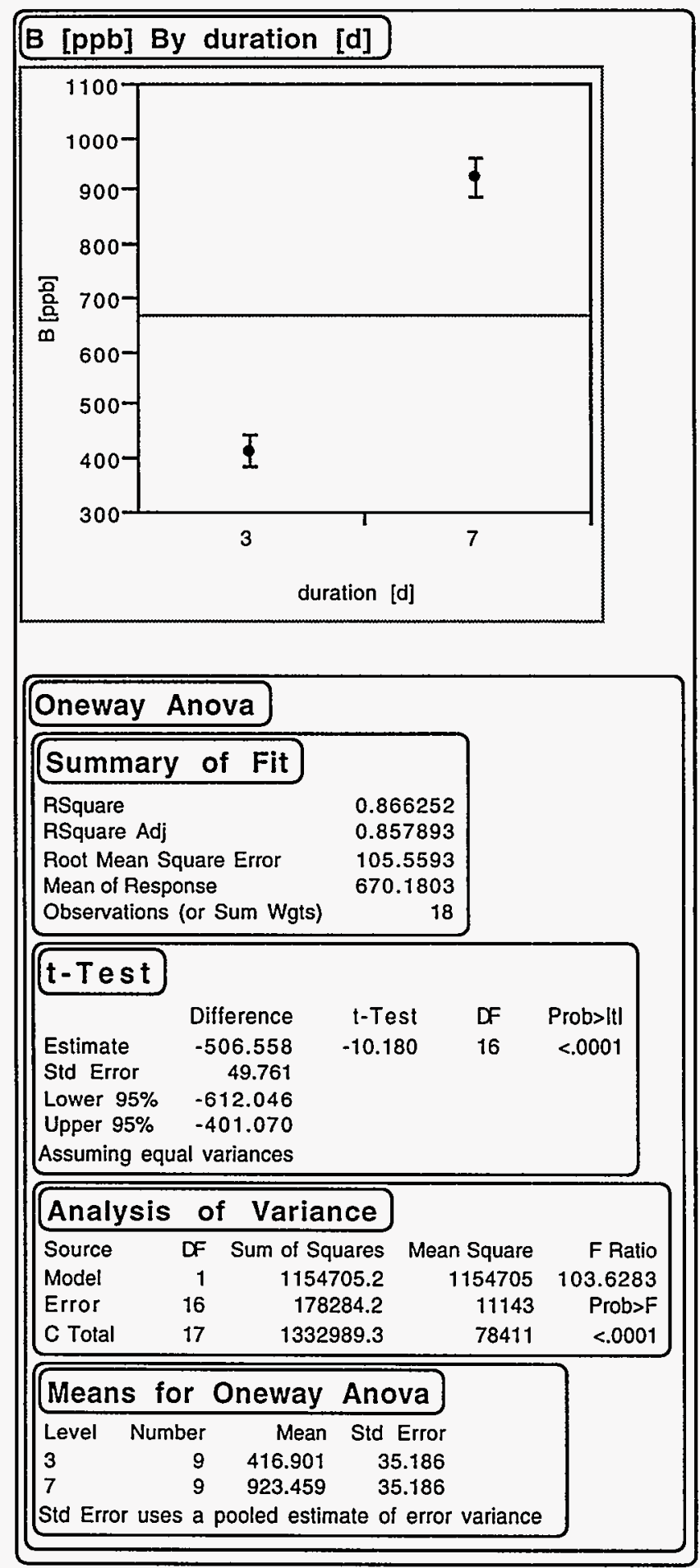


Figure F-3. One-Way ANOVA for $\mathrm{Na}$ Concentration in Leachates from $1: 10,70^{\circ} \mathrm{C}$ Tests by Test Duration.

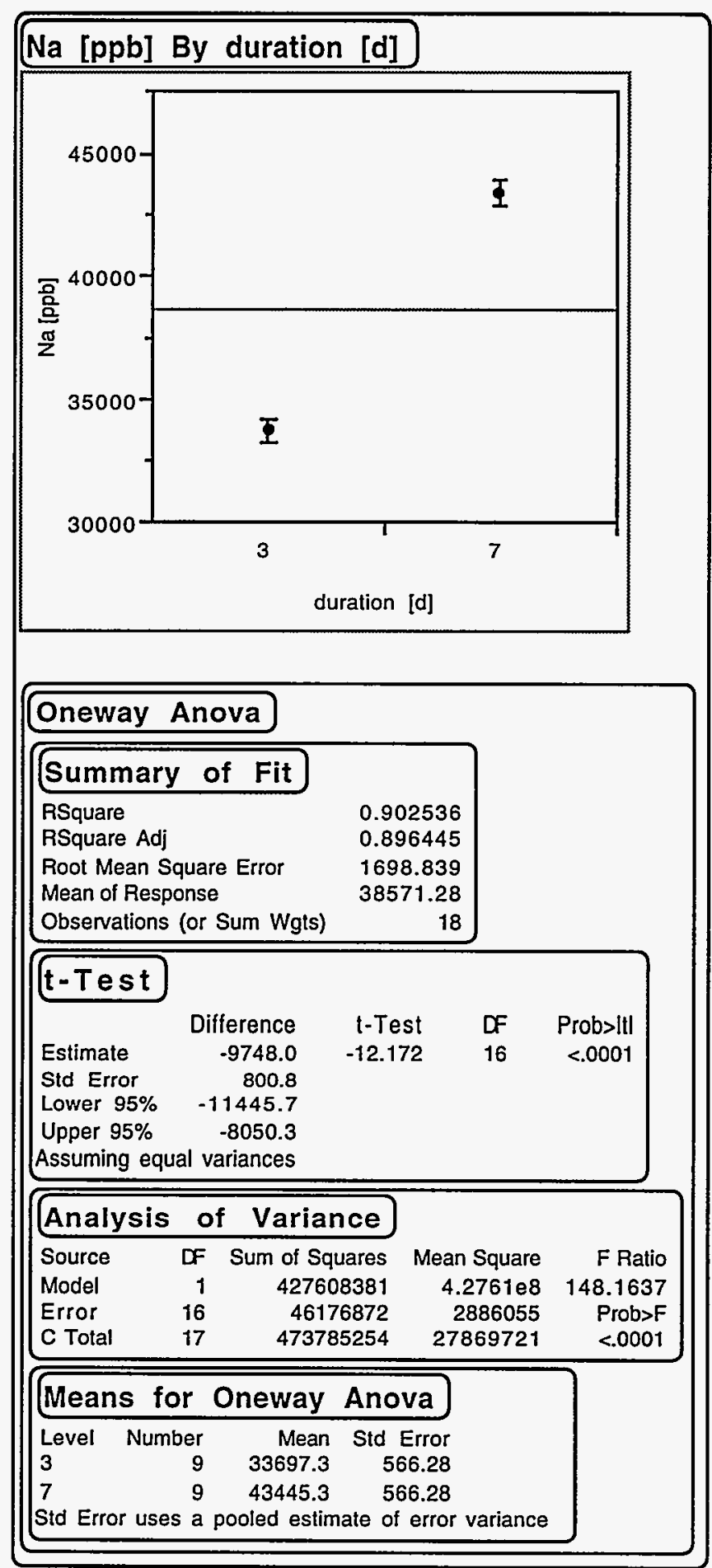


Figure F-3, contd. One-Way ANOVA for Si Concentration in Leachates from $1: 10,70^{\circ} \mathrm{C}$ Tests by Test Duration.

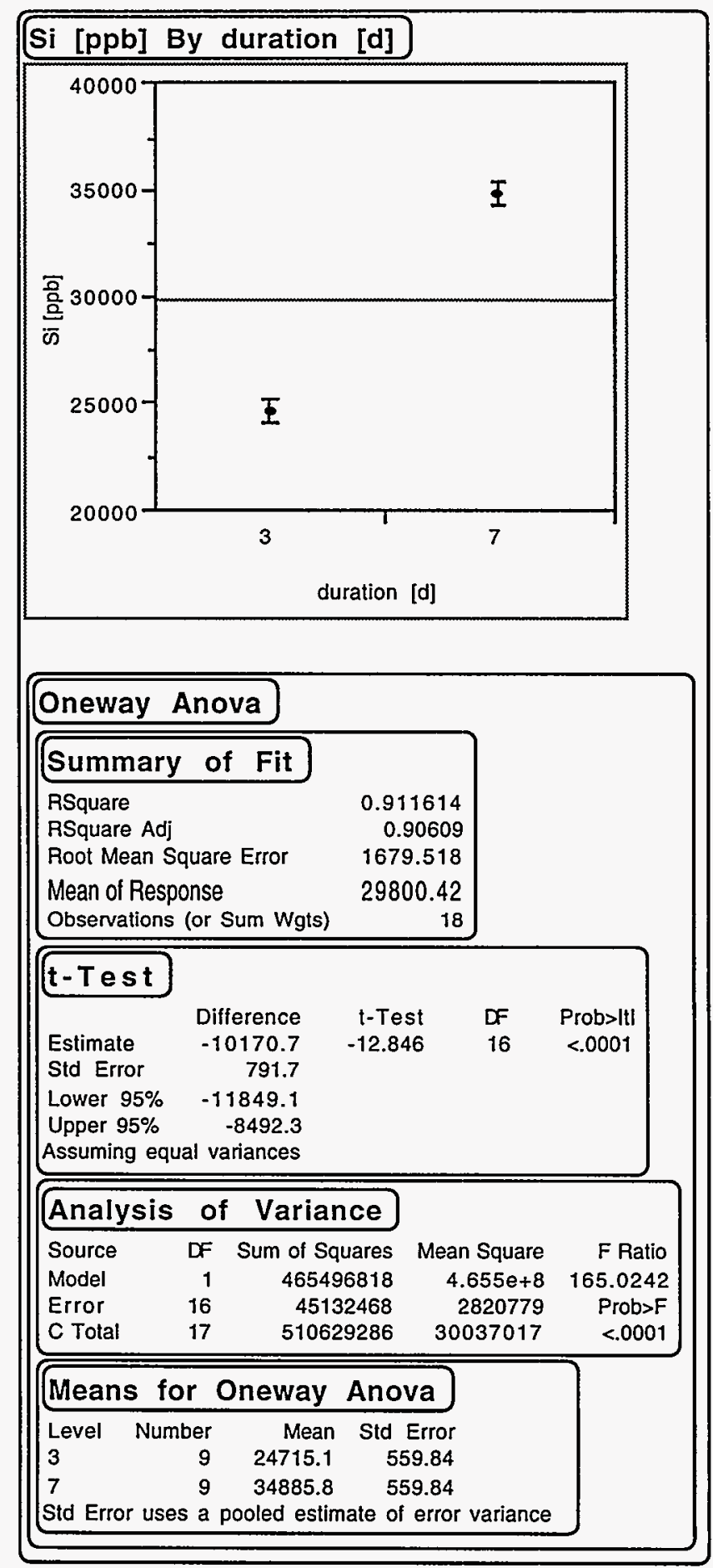


Figure F-3, contd. One-Way ANOVA for B Concentration in Leachates from $1: 10,70^{\circ} \mathrm{C}$ Tests by Test Duration.

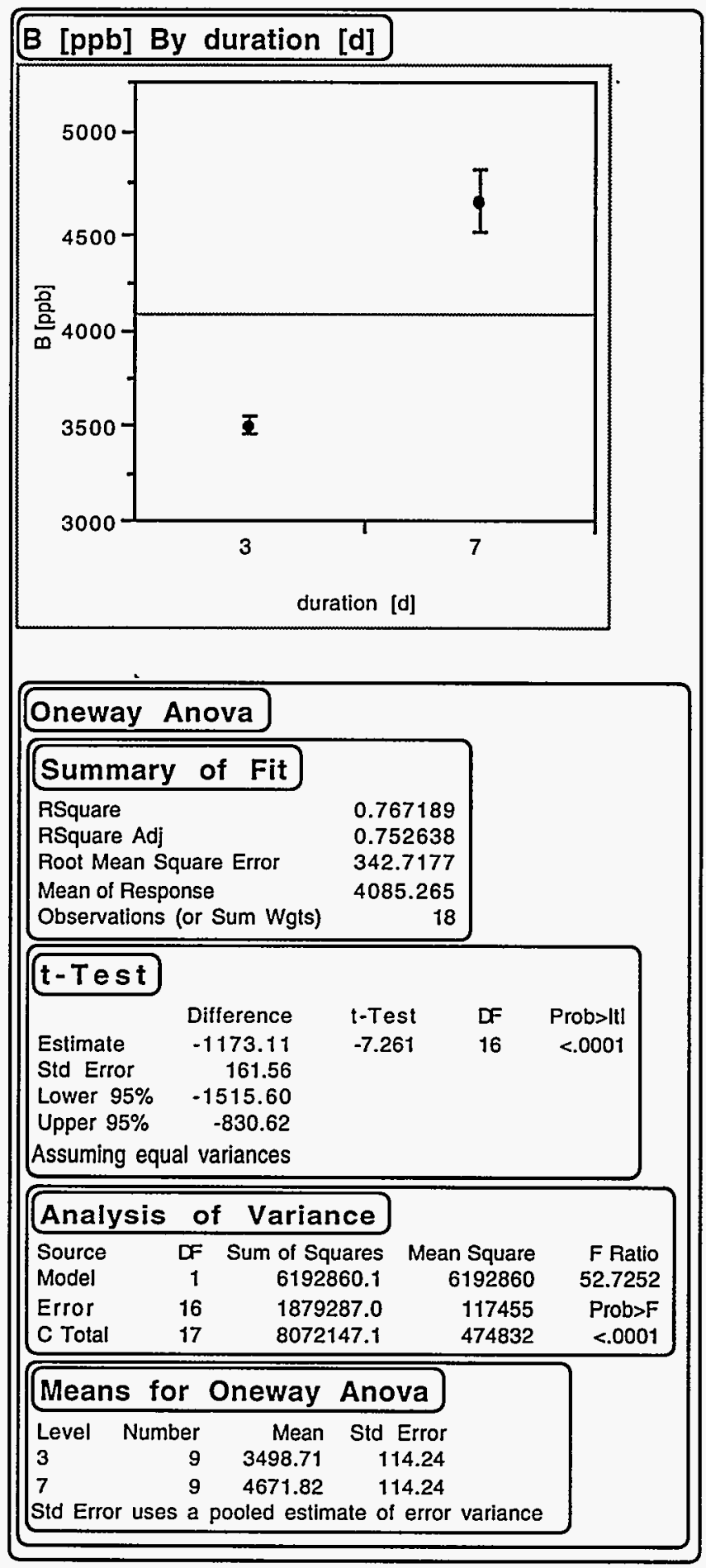


Figure F-4. One-Way ANOVA for Na Concentration in Leachates from $1: 1,20^{\circ} \mathrm{C}$ Tests by Test Duration.

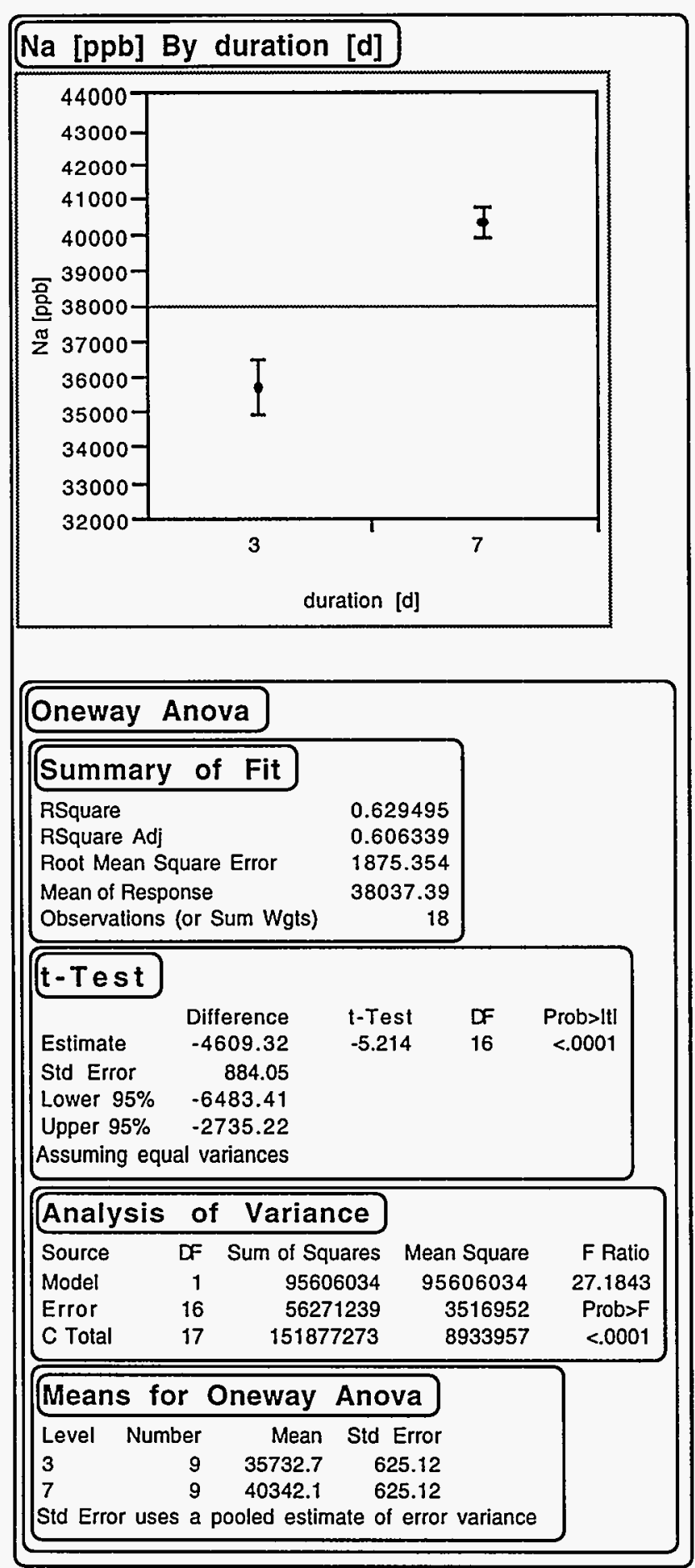


Figure F-4, contd. One-Way ANOVA for Si Concentration in Leachates from $1: 1,20^{\circ} \mathrm{C}$ Tests by Test Duration.

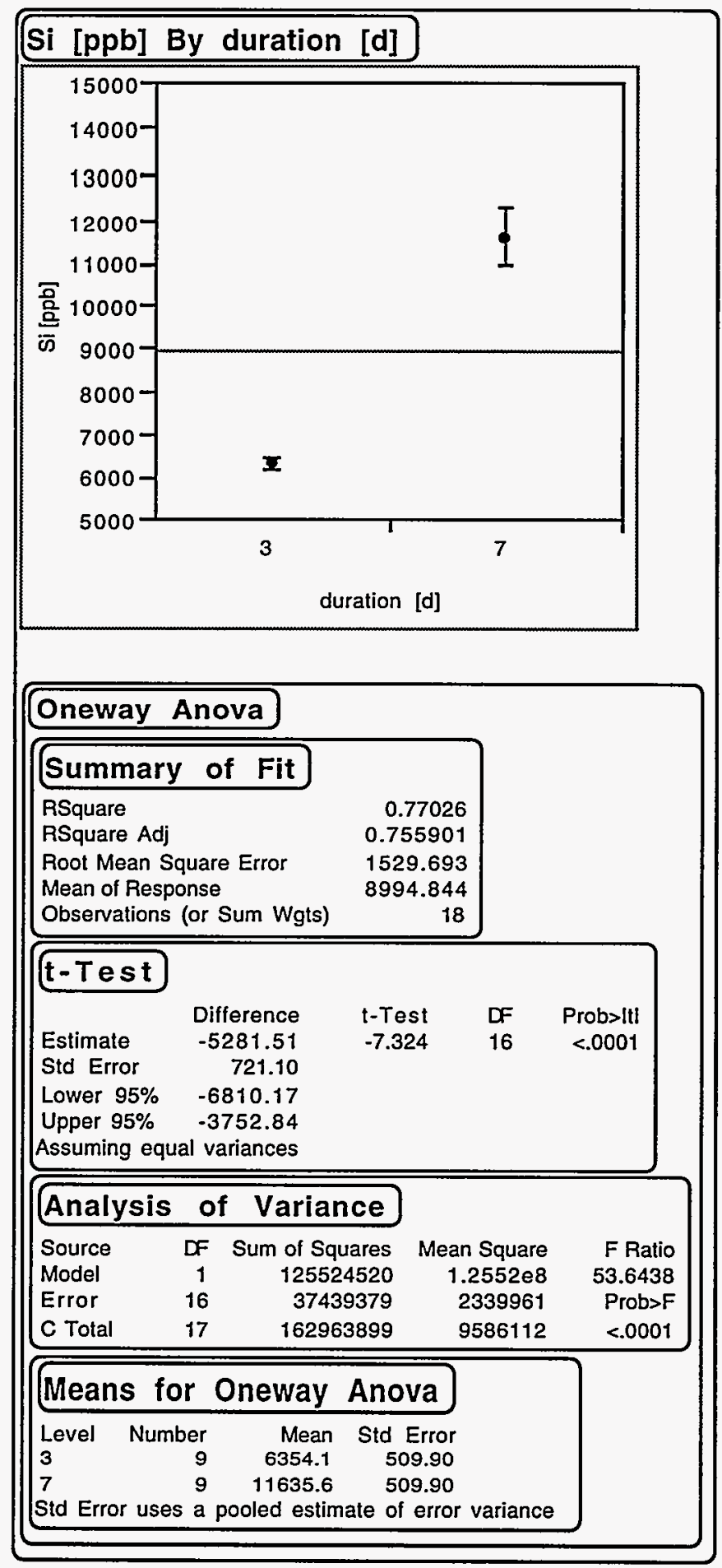


Figure F-4, contd. One-Way ANOVA for B Concentration in Leachates from $1: 1,20^{\circ} \mathrm{C}$ Tests by Test Duration.

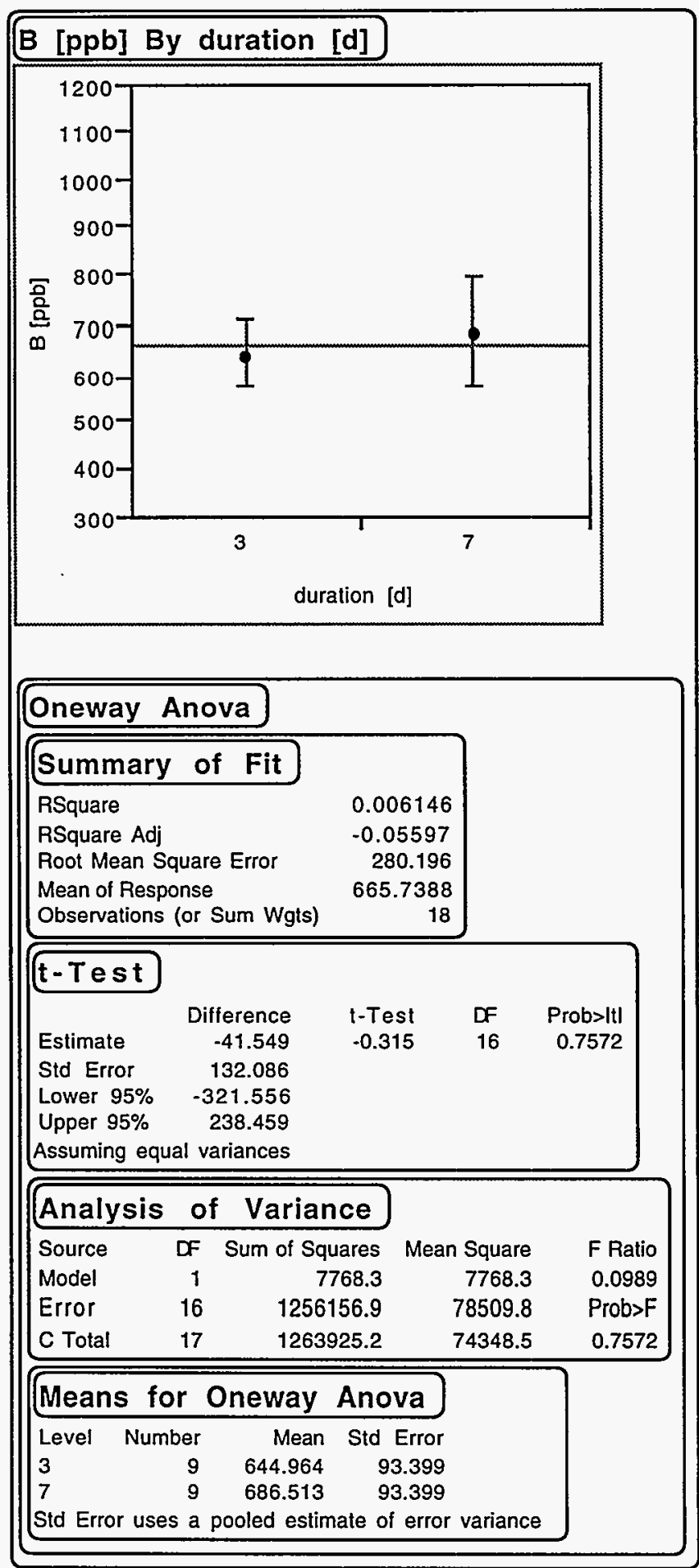


Figure F-5. One-Way ANOVA for $\mathrm{Na}$ Concentration in Leachates from $1: 1,40^{\circ} \mathrm{C}$ Tests by Test Duration.

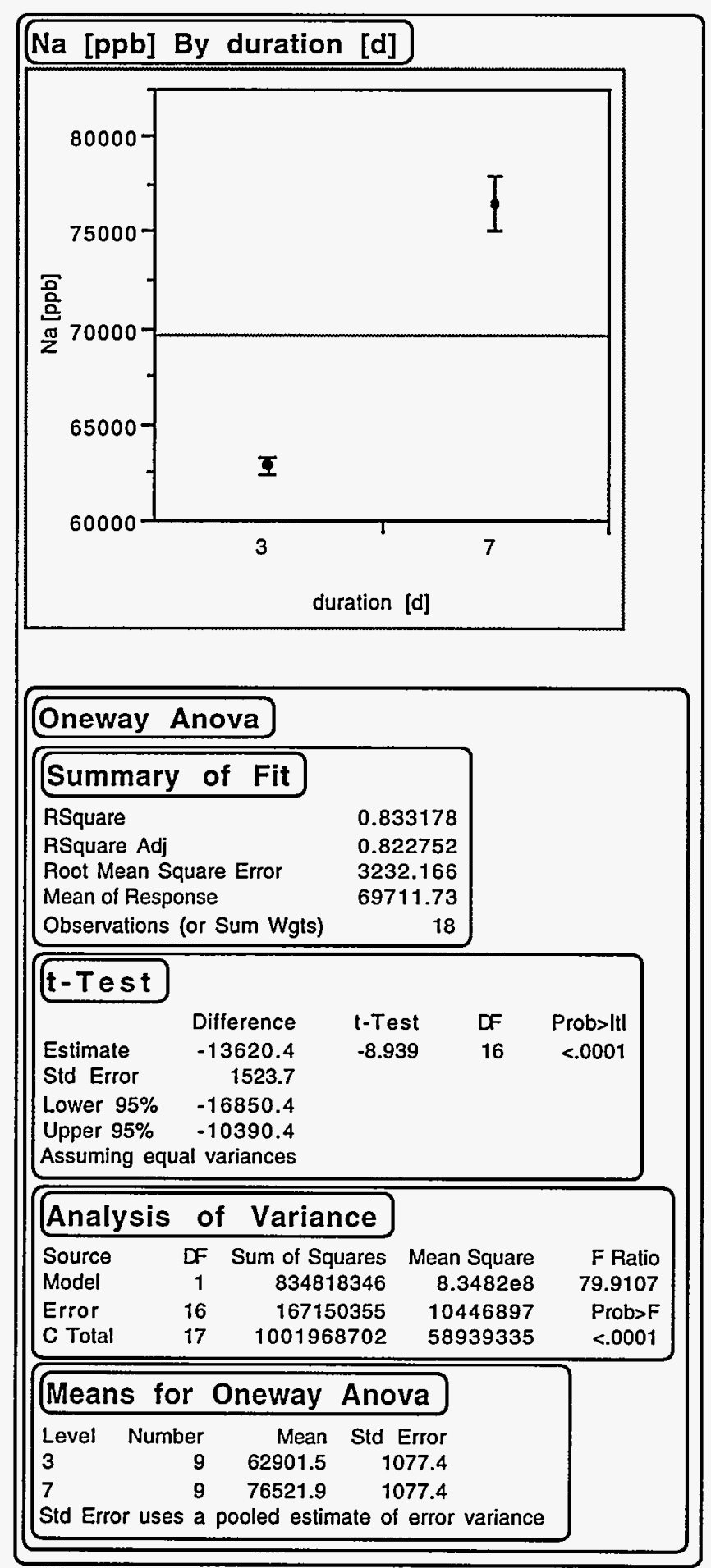


Figure F-5, contd. One-Way ANOVA for Si Concentration in Leachates from $1: 1,40^{\circ} \mathrm{C}$ Tests by Test Duration.

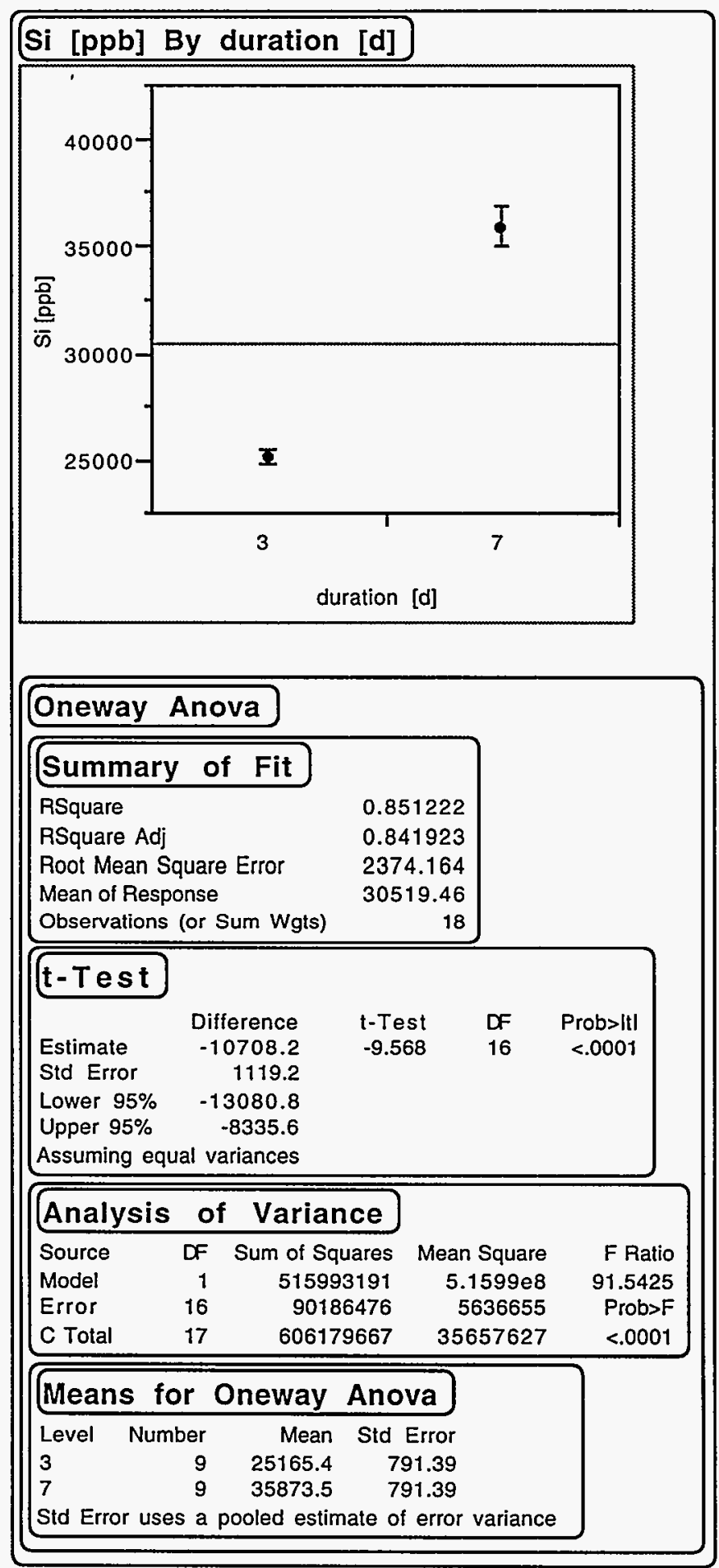


Figure F-5, contd. One-Way ANOVA for B Concentration in Leachates from $1: 1,40^{\circ} \mathrm{C}$ Tests by Test Duration.

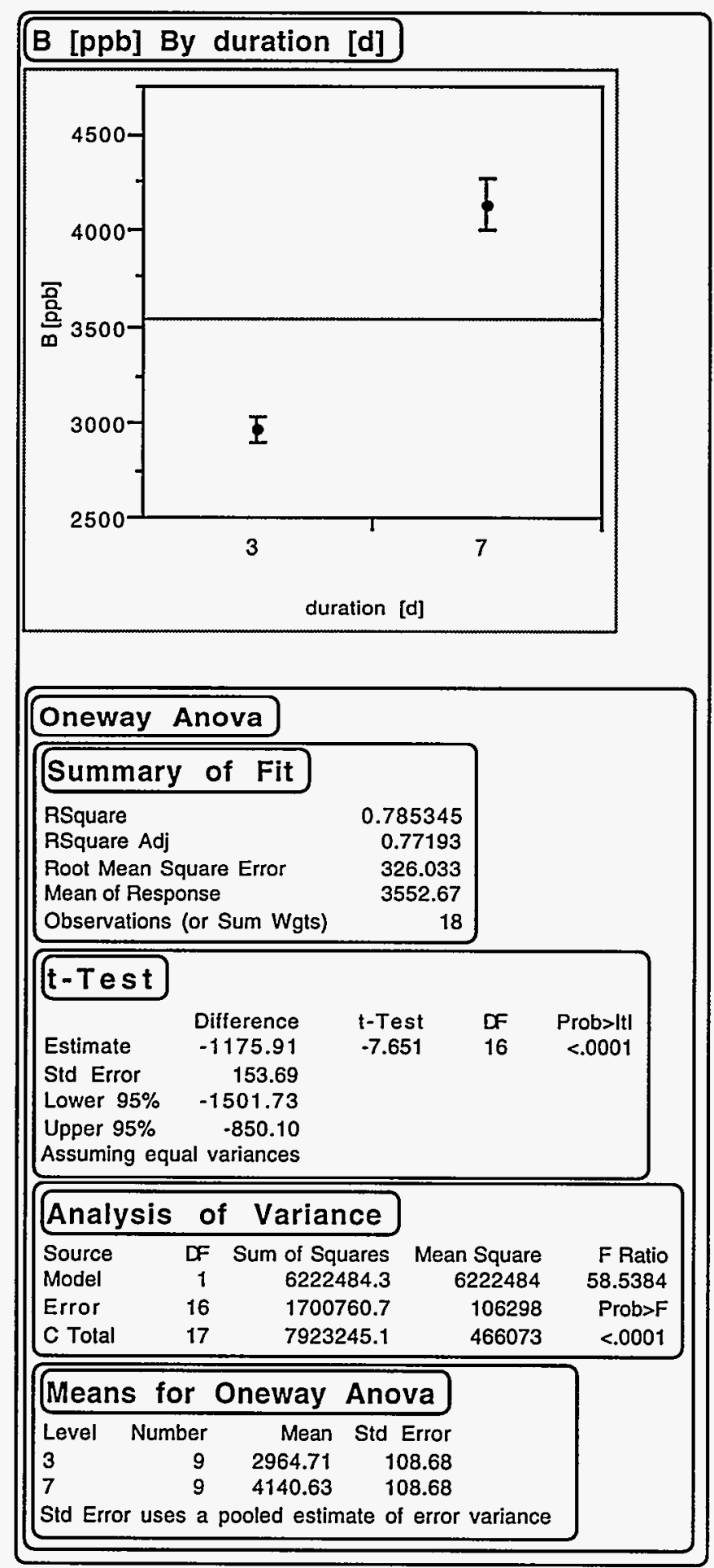


Figure F-6. One-Way ANOVA for Na Concentration in Leachates from $1: 1,70^{\circ} \mathrm{C}$ Tests by Test Duration.

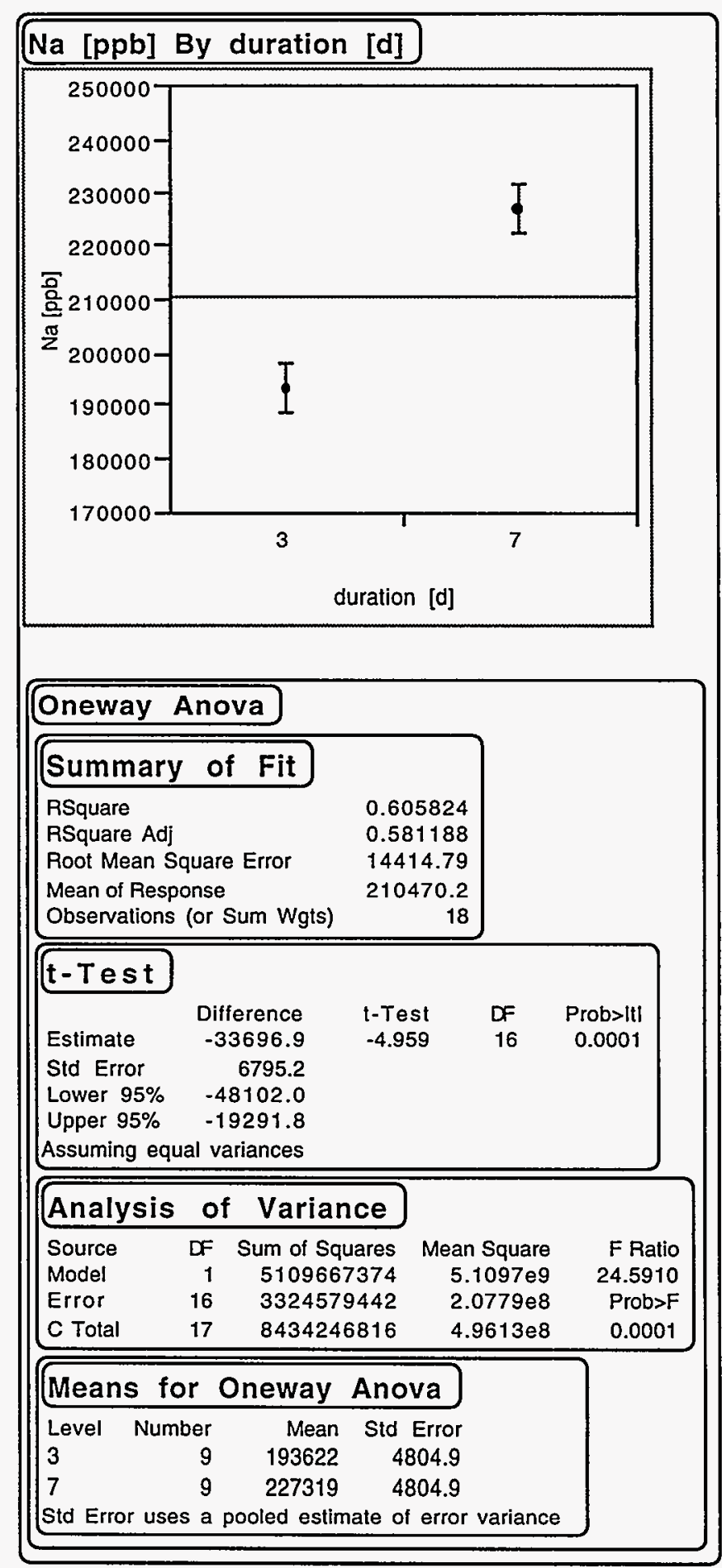


Figure F-6, contd. One-Way ANOVA for Si Concentration in Leachates from $1: 1,70^{\circ} \mathrm{C}$ Tests by Test Duration.

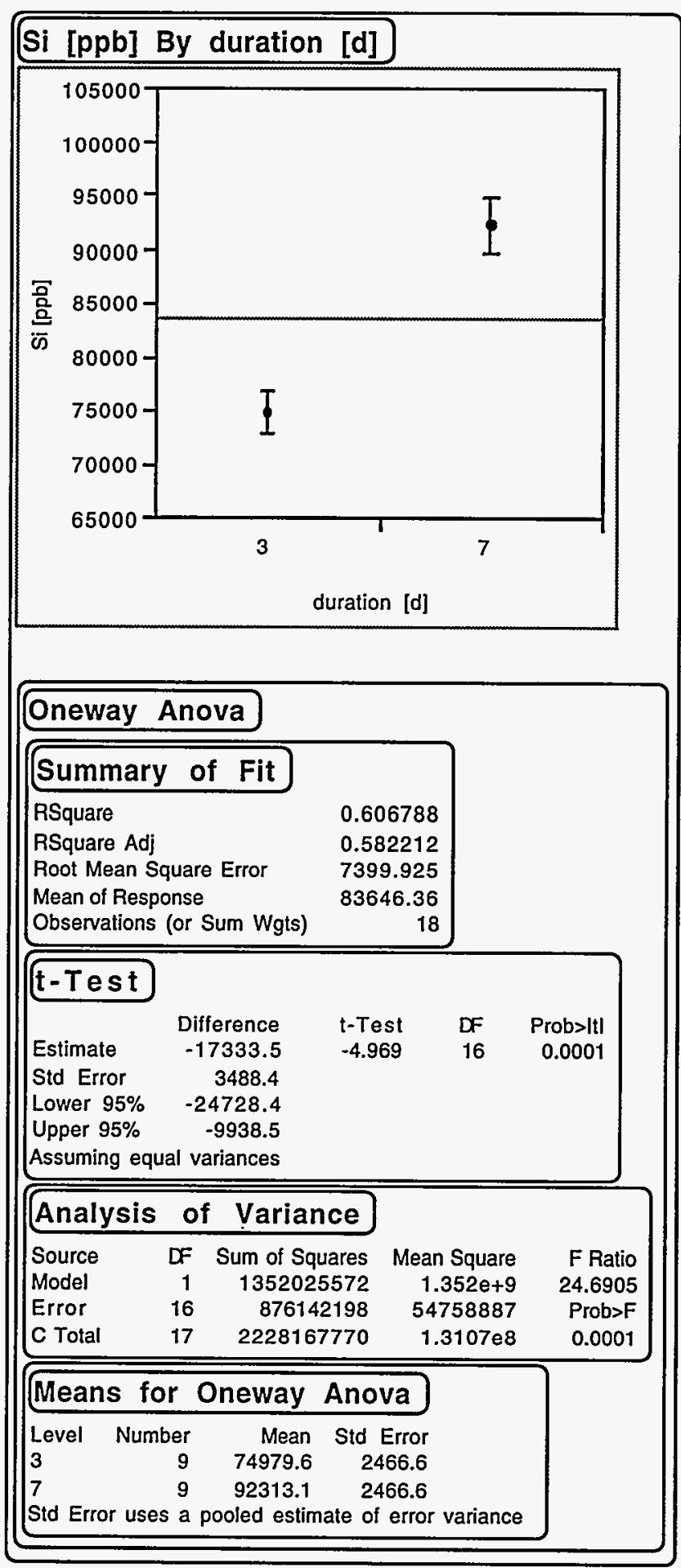


Figure F-6, contd. One-Way ANOVA for B Concentration in Leachates from $1: 1,70^{\circ} \mathrm{C}$ Tests by Test Duration.

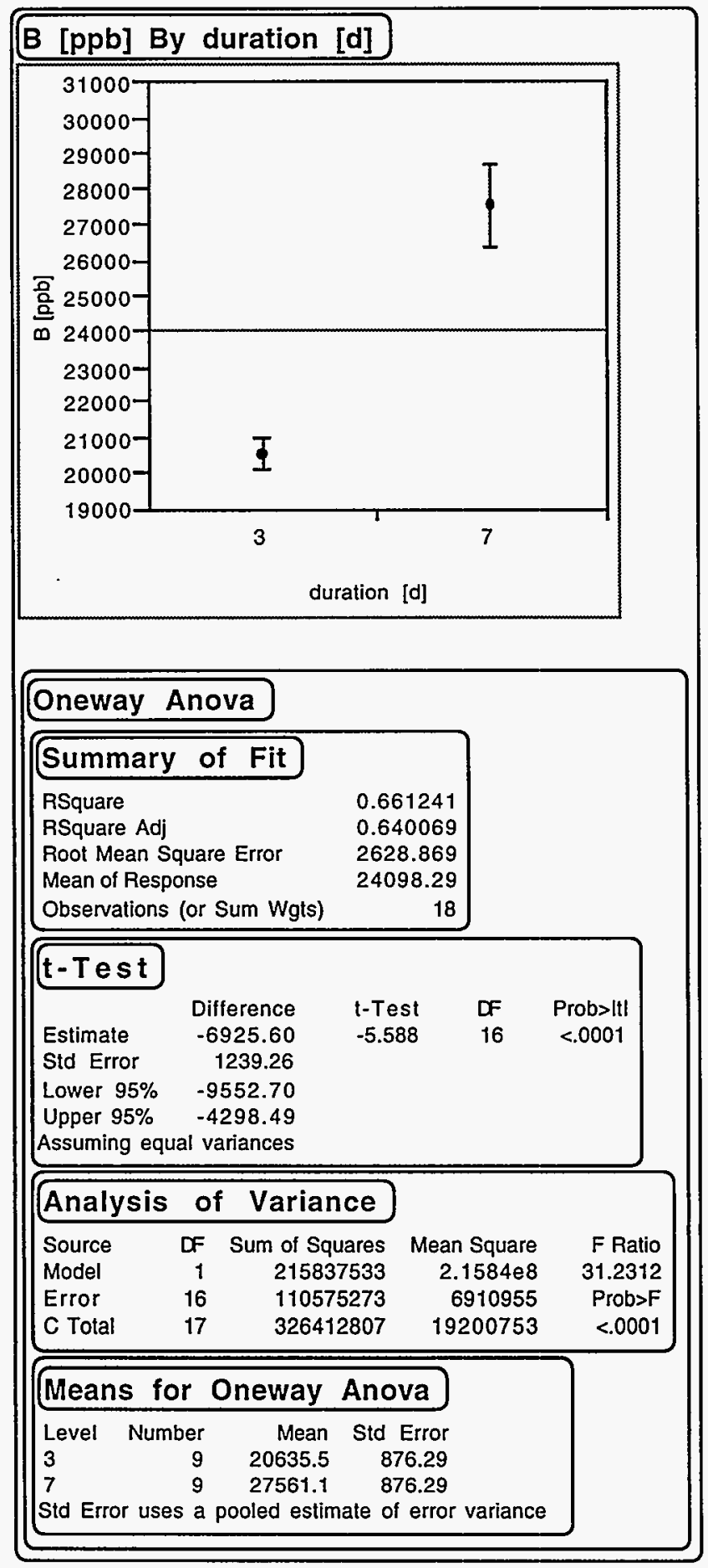




\section{APPENDIX G. ANALYSIS OF VARIANCE BY TRIPLICATE TEST}

Figure G-1. One-Way ANOVA for Na Concentration in Leachates from 3-day, 1:10, $20^{\circ} \mathrm{C}$ Tests by Set of Triplicate Tests.

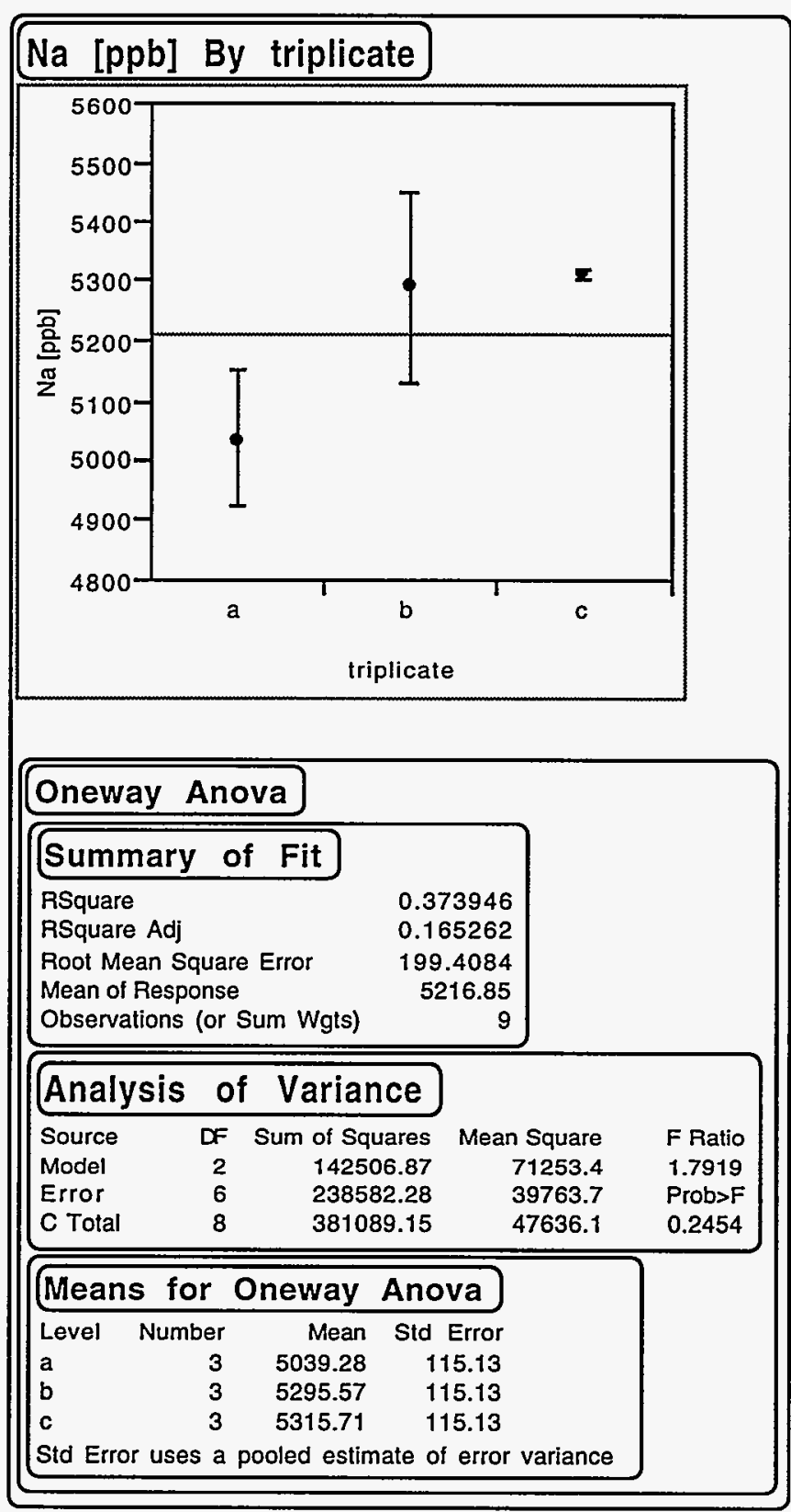


Figure G-1, contd. One-Way ANOVA for Si Concentration in Leachates from 3-day, 1:10, $20^{\circ} \mathrm{C}$ Tests by Set of Triplicate Tests.

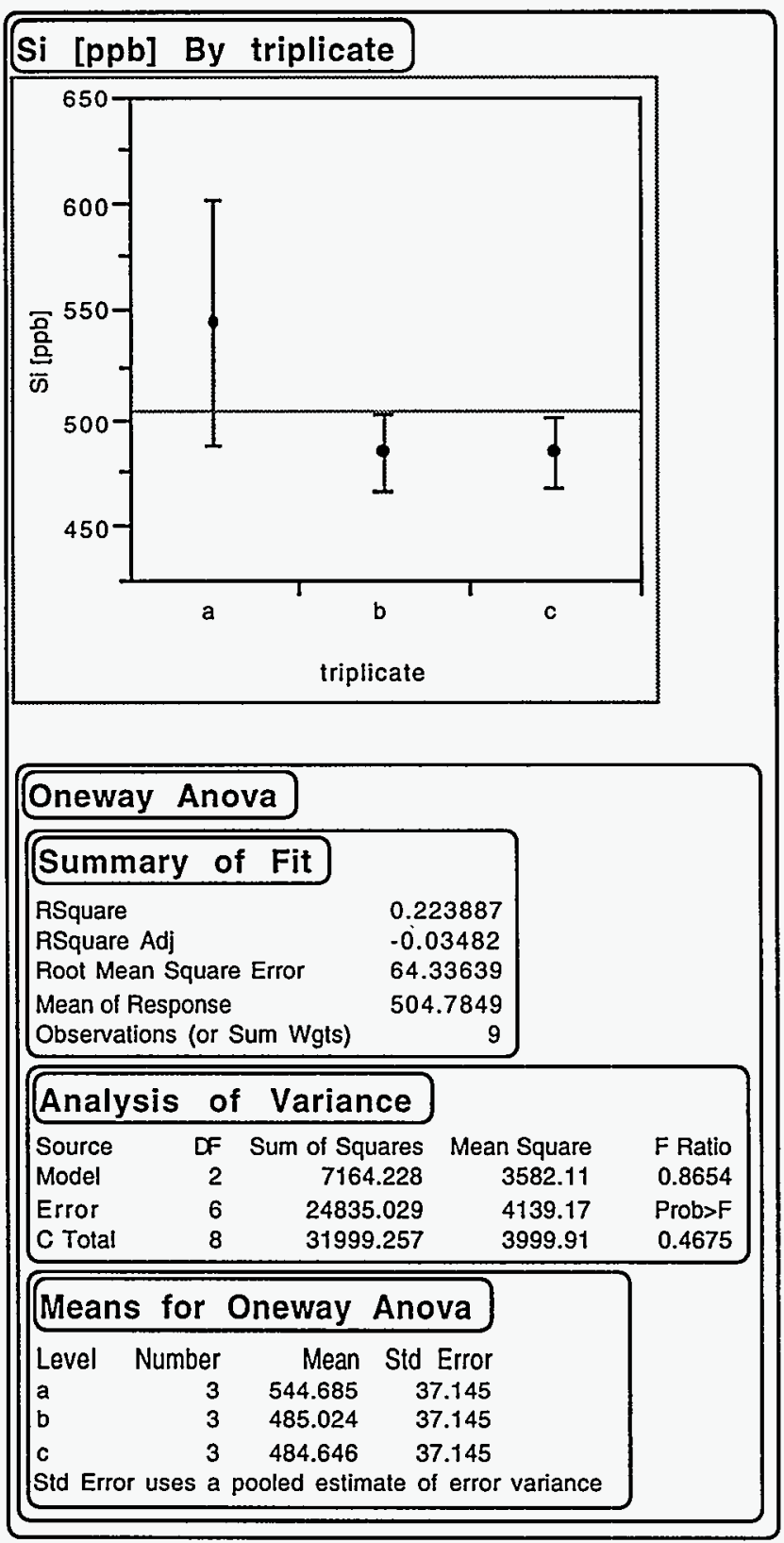


Figure G-1, contd. One-Way ANOVA for B Concentration in Leachates from 3-day, 1:10, $20^{\circ} \mathrm{C}$ Tests by Set of Triplicate Tests.

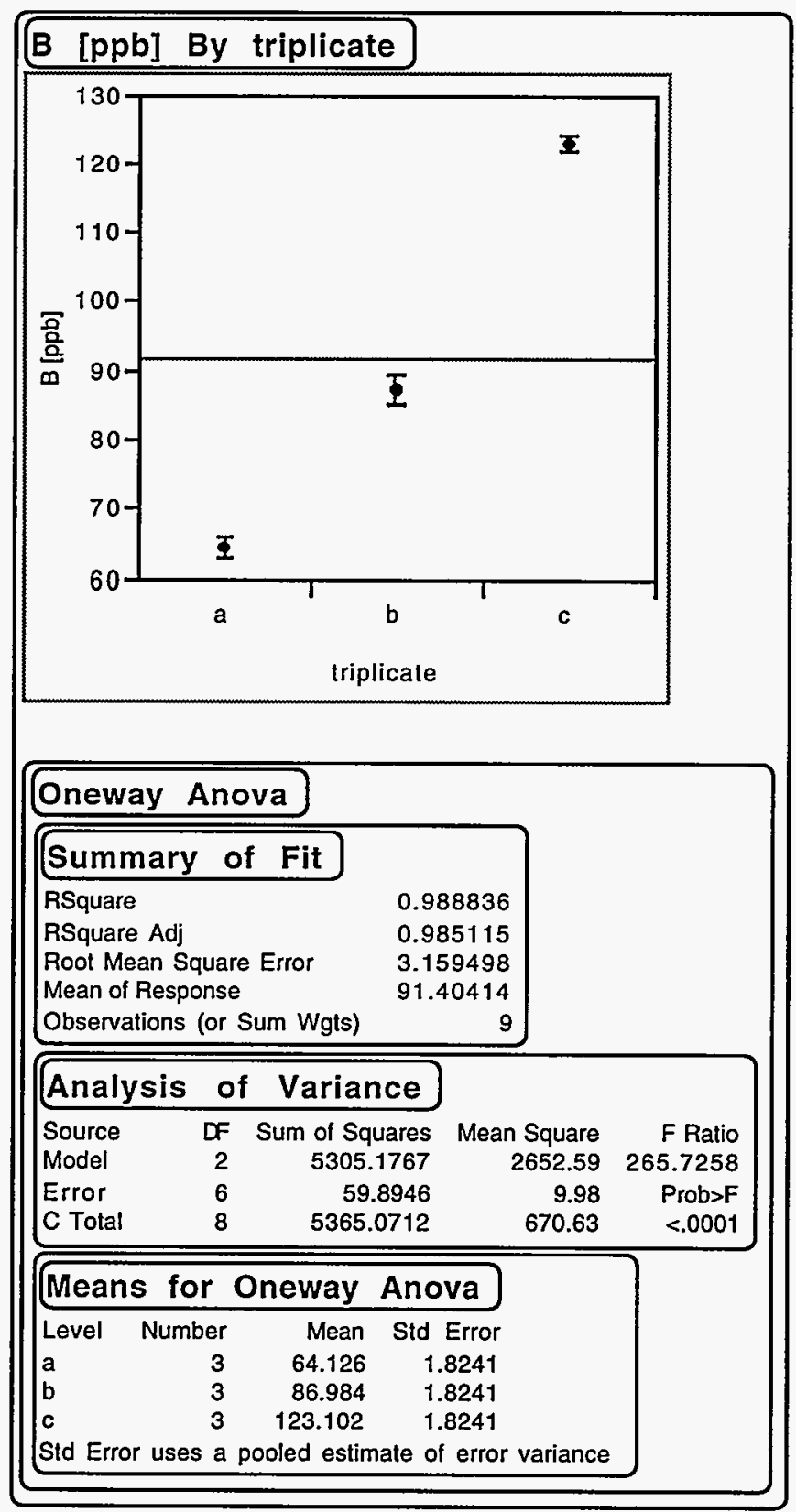


Figure G-2. One-Way ANOVA for Na Concentration in Leachates from 3-day, 1:10, $40^{\circ} \mathrm{C}$ Tests by Set of Triplicate Tests.

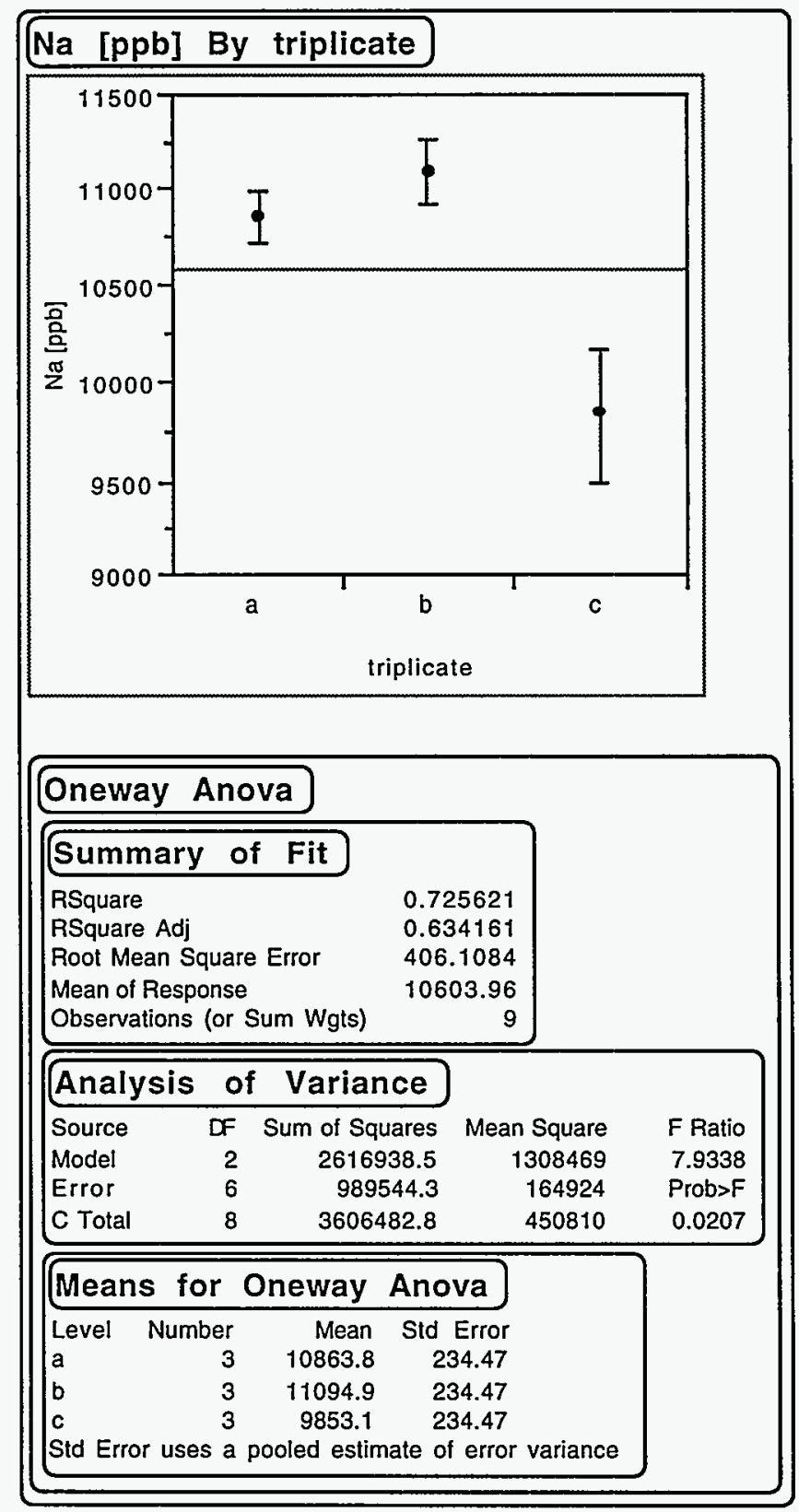


Figure G-2, contd. One-Way ANOVA for Si Concentration in Leachates from 3-day, 1:10, $40^{\circ} \mathrm{C}$ Tests by Set of Triplicate Tests.

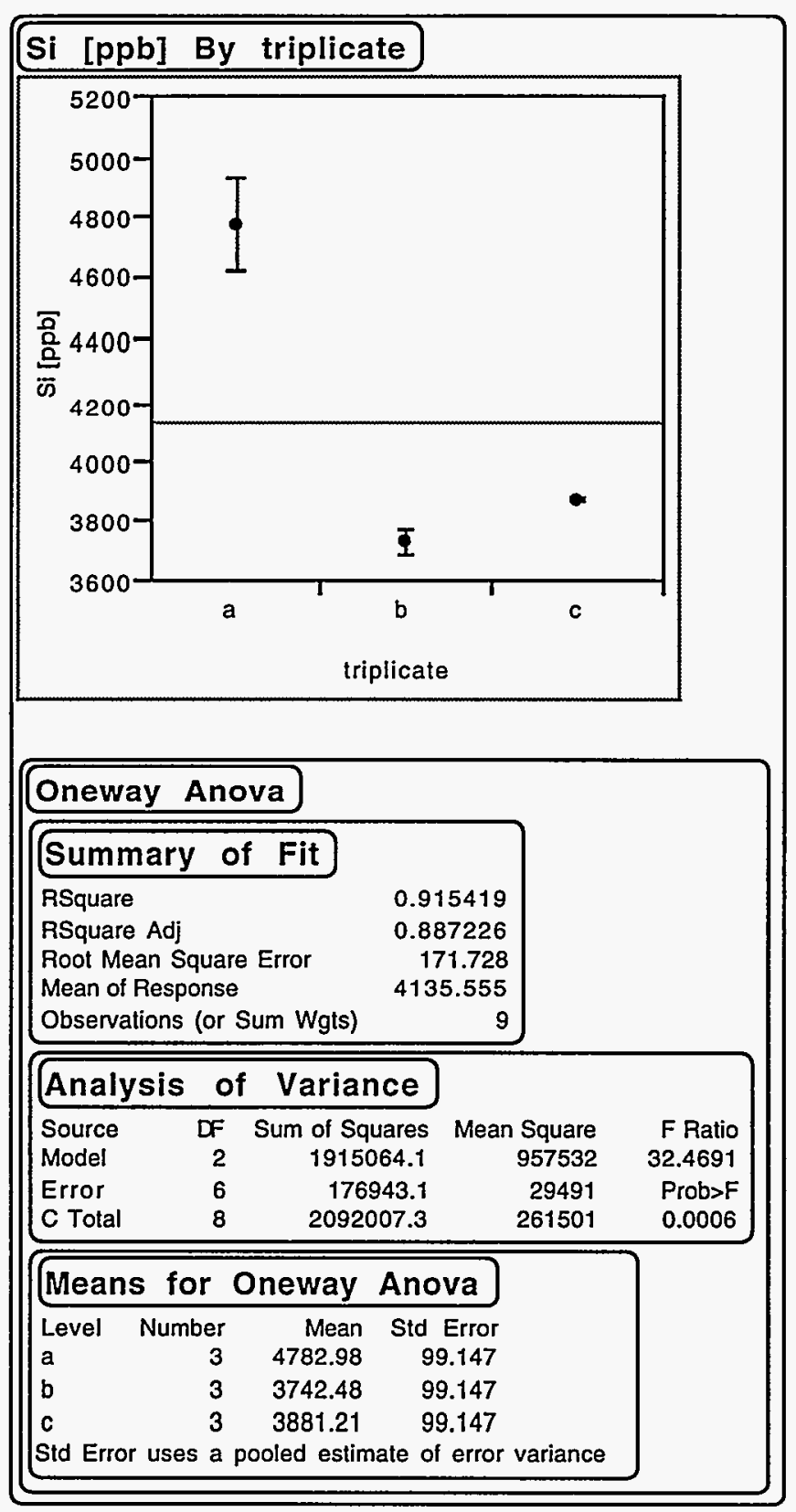


Figure G-2, contd. One-Way ANOVA for B Concentration in Leachates from 3-day, 1:10, $40^{\circ} \mathrm{C}$ Tests by Set of Triplicate Tests.

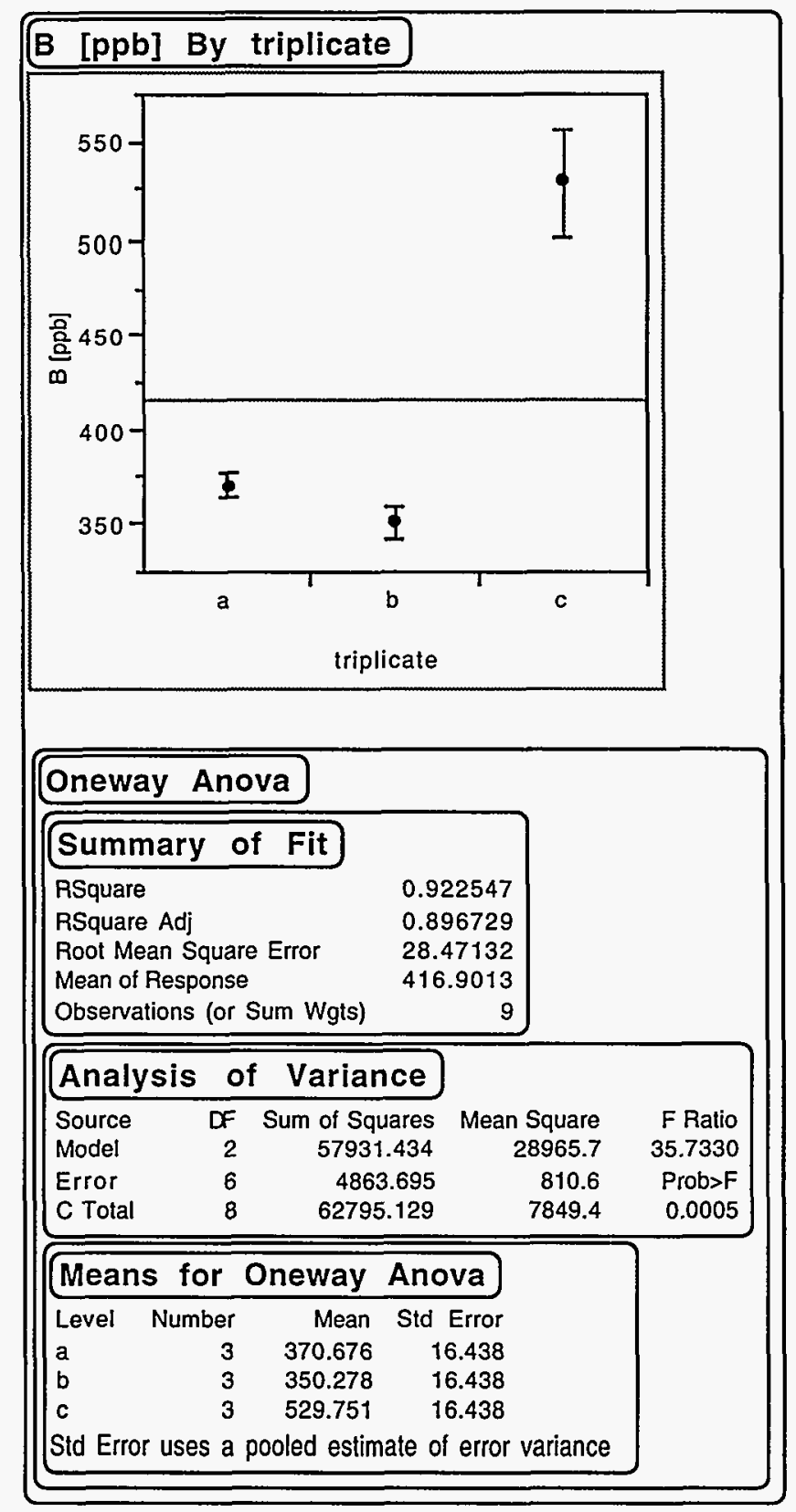


Figure G-3. One-Way ANOVA for Na Concentration in Leachates from 3-day, 1:10, $70^{\circ} \mathrm{C}$ Tests by Set of Triplicate Tests.

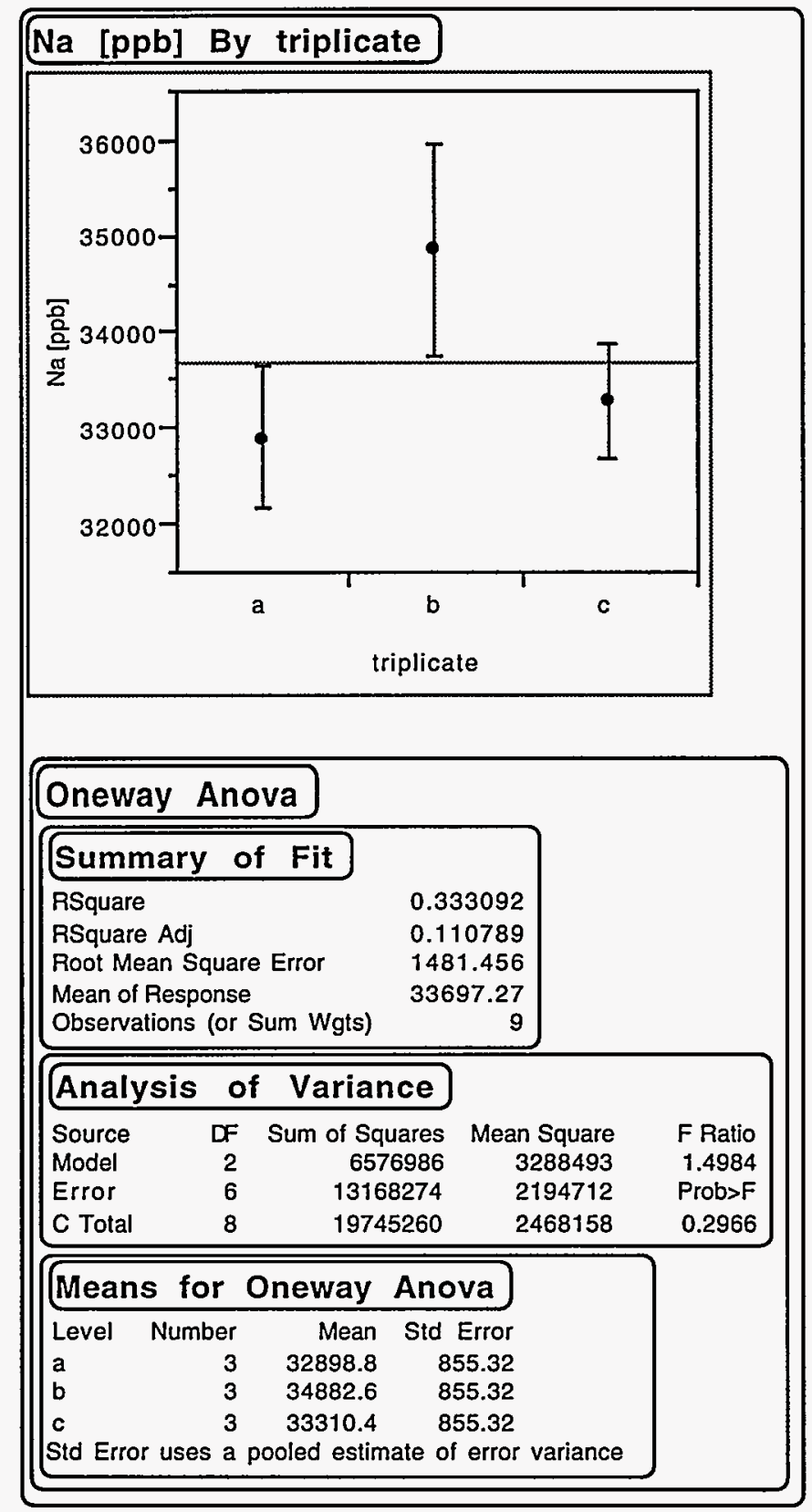


Figure G-3, contd. One-Way ANOVA for Si Concentration in Leachates from 3-day, 1:10, $70^{\circ} \mathrm{C}$ Tests by Set of Triplicate Tests.

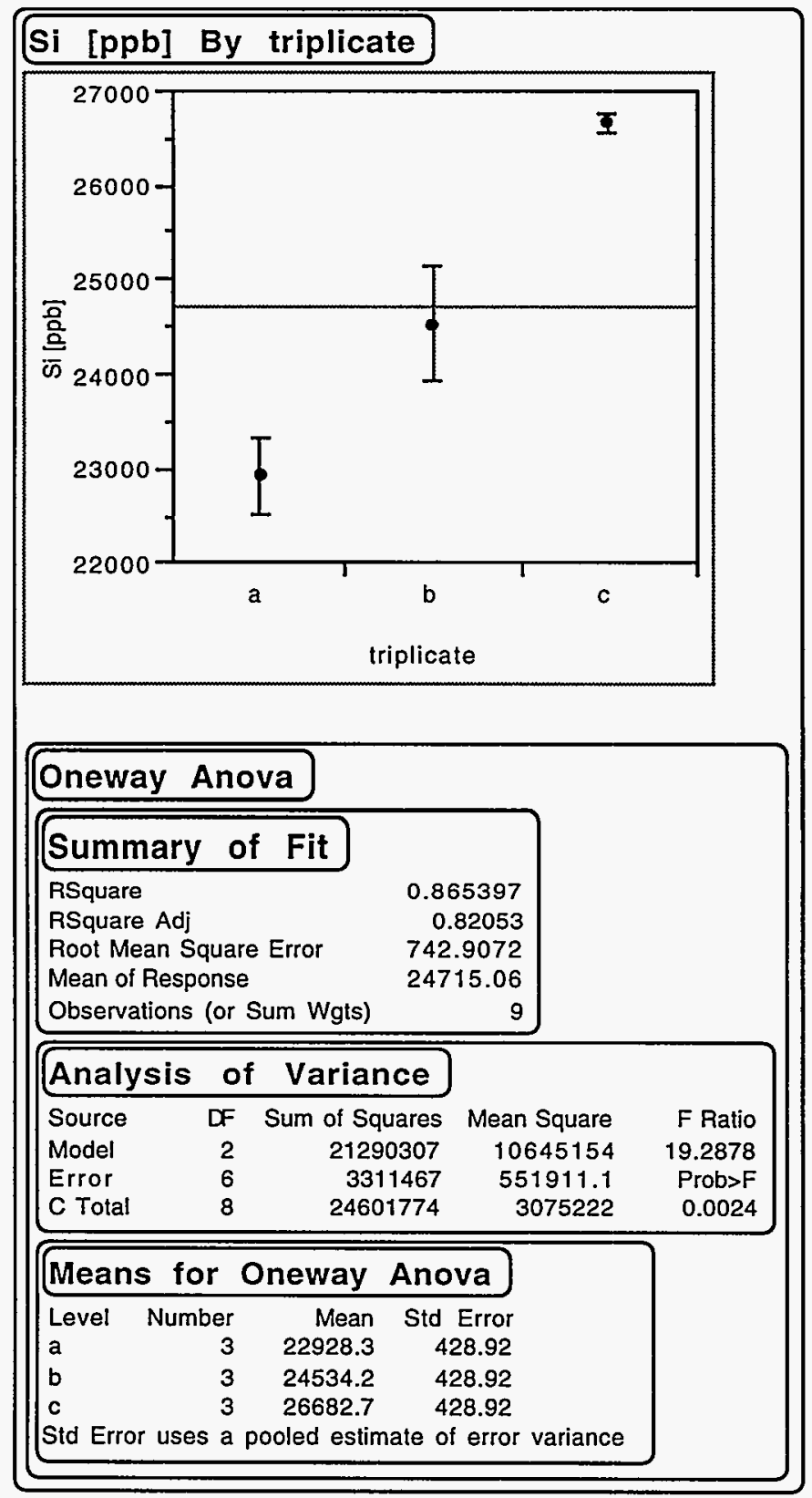


Figure G-3, contd. One-Way ANOVA for B Concentration in Leachates from 3-day, 1:10, $70^{\circ} \mathrm{C}$ Tests by Set of Triplicate Tests.

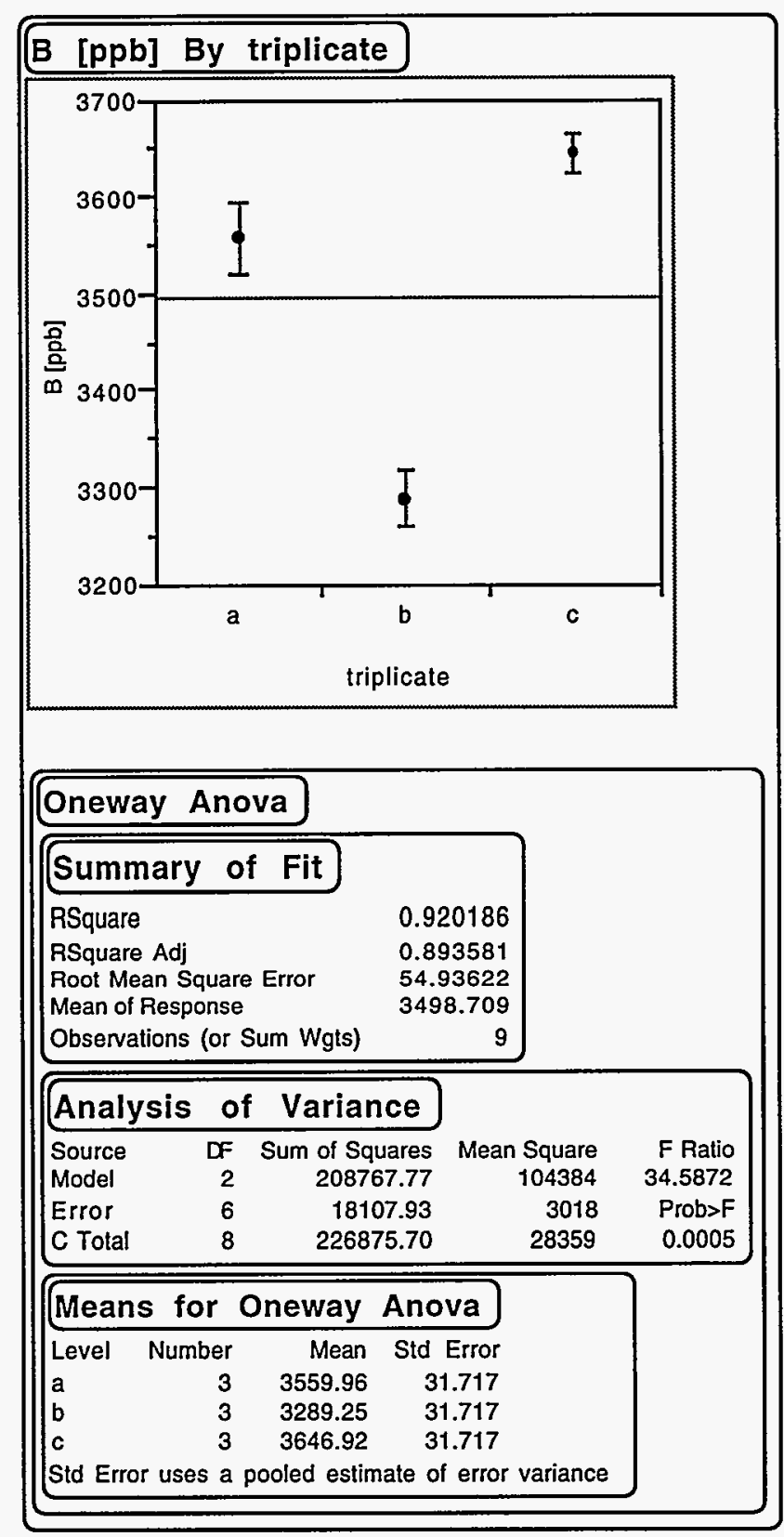


Figure G-4. One-Way ANOVA for $\mathrm{Na}$ Concentration in Leachates from 3-day, $1: 1,20^{\circ} \mathrm{C}$ Tests by Set of Triplicate Tests.

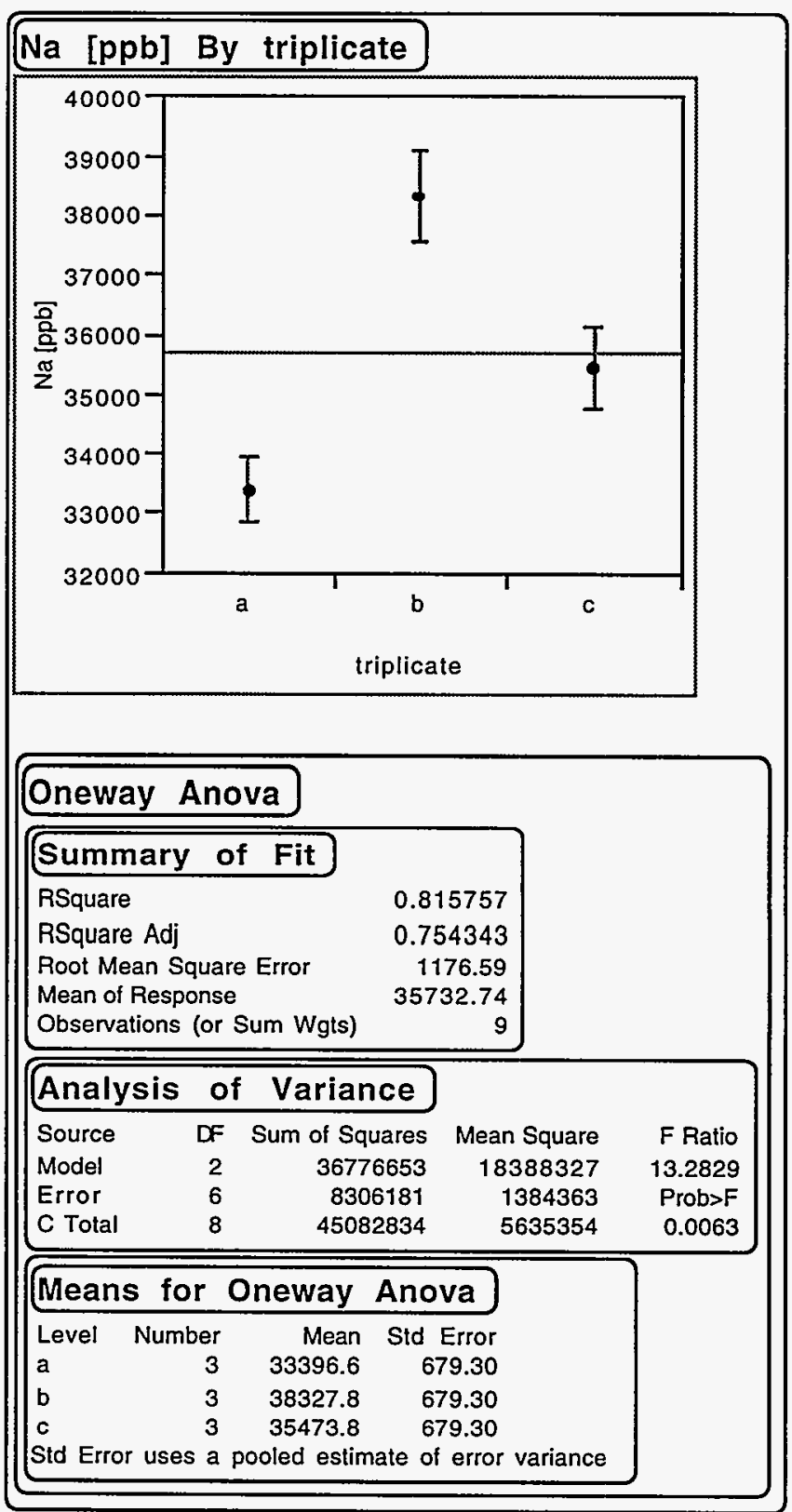


Figure G-4, contd. One-Way ANOVA for Si Concentration in Leachates from 3-day, 1:1, $20^{\circ} \mathrm{C}$ Tests by Set of Triplicate Tests.

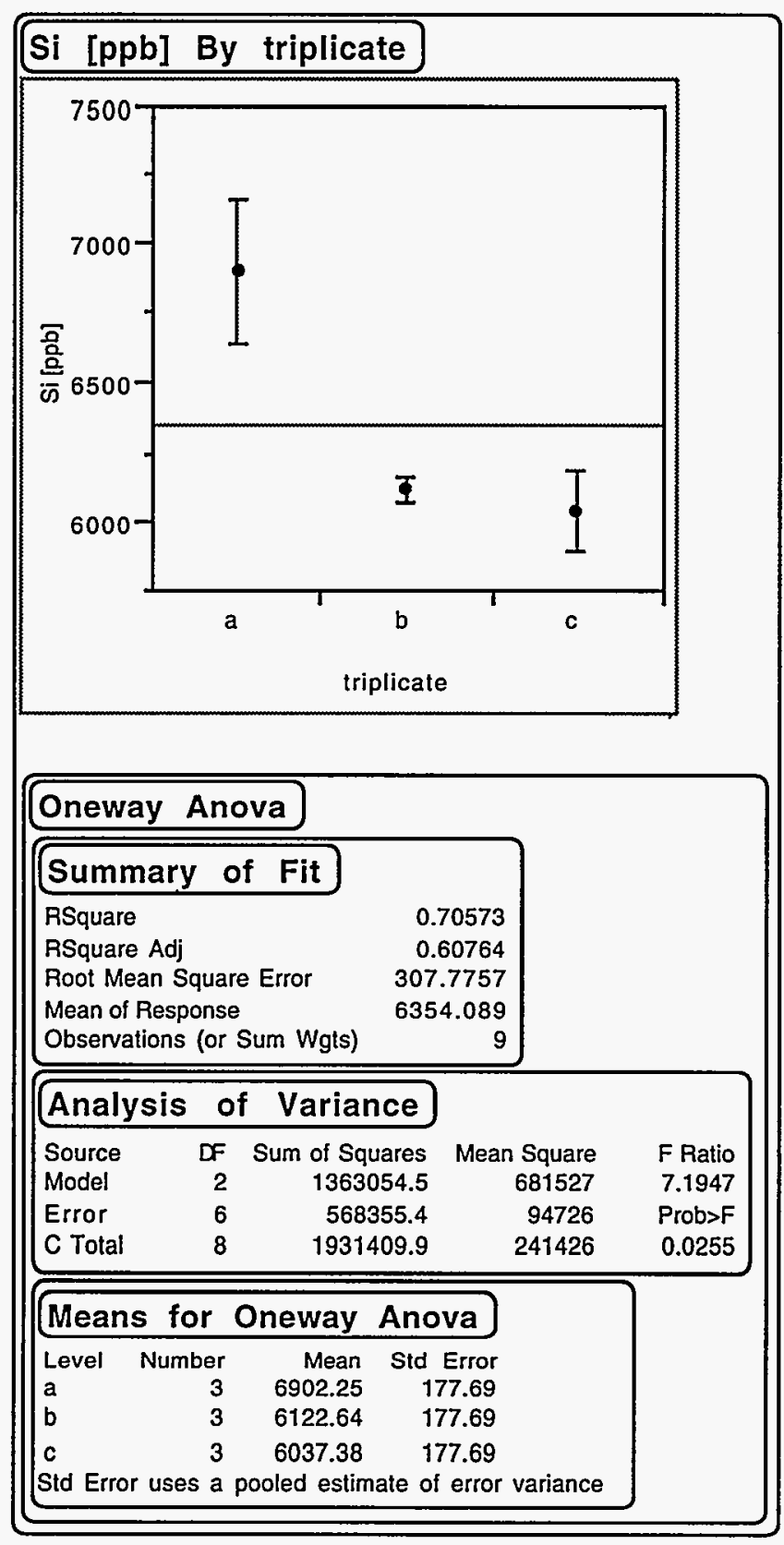


Figure G-4, contd. One-Way ANOVA for B Concentration in Leachates from 3-day, 1:1, $20^{\circ} \mathrm{C}$ Tests by Set of Triplicate Tests.

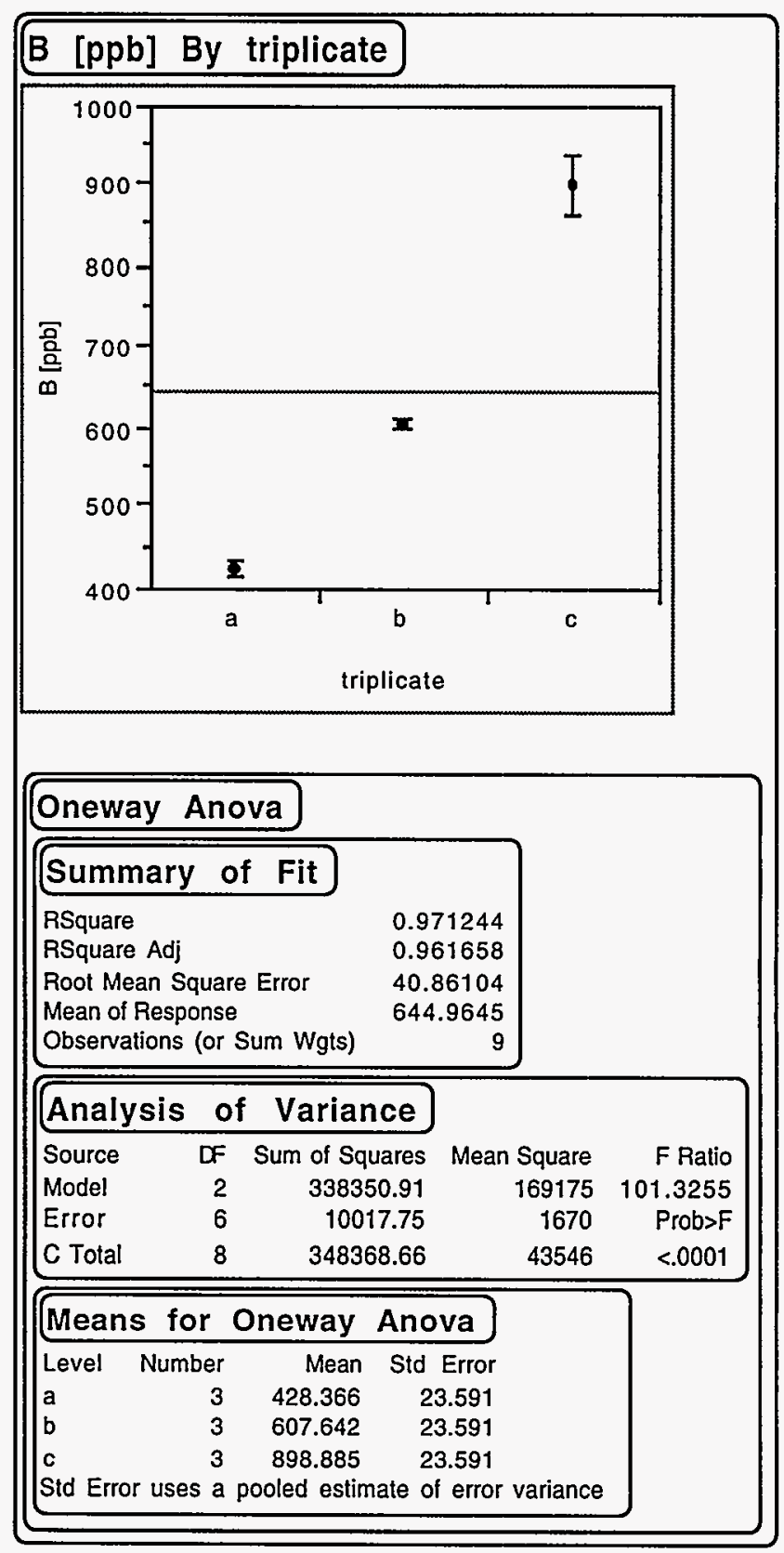


Figure G-5. One-Way ANOVA for Na Concentration in Leachates from 3-day, 1:1, $40^{\circ} \mathrm{C}$ Tests by Set of Triplicate Tests.

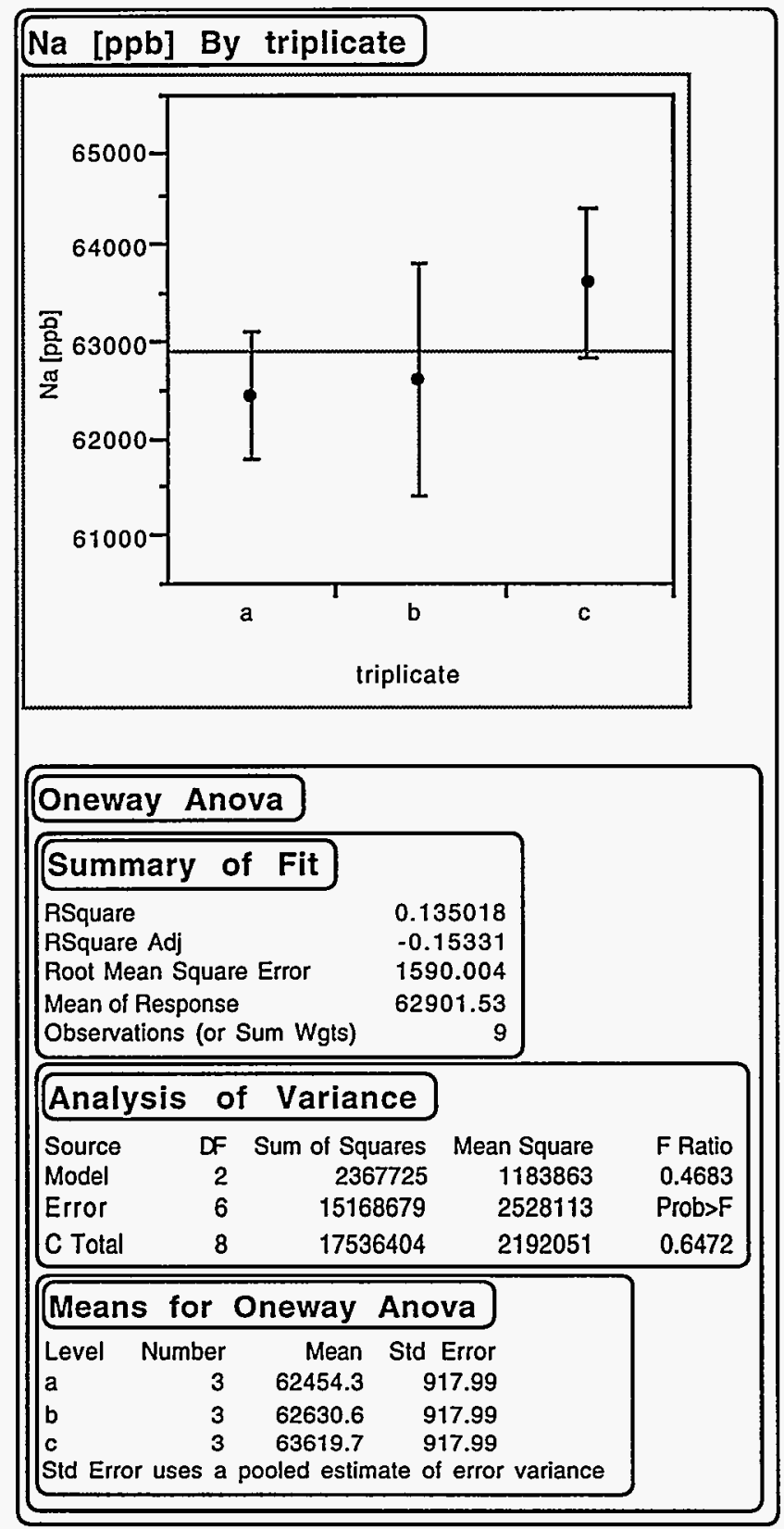


Figure G-5, contd. One-Way ANOVA for Si Concentration in Leachates from 3-day, 1:1, $40^{\circ} \mathrm{C}$ Tests by Set of Triplicate Tests.

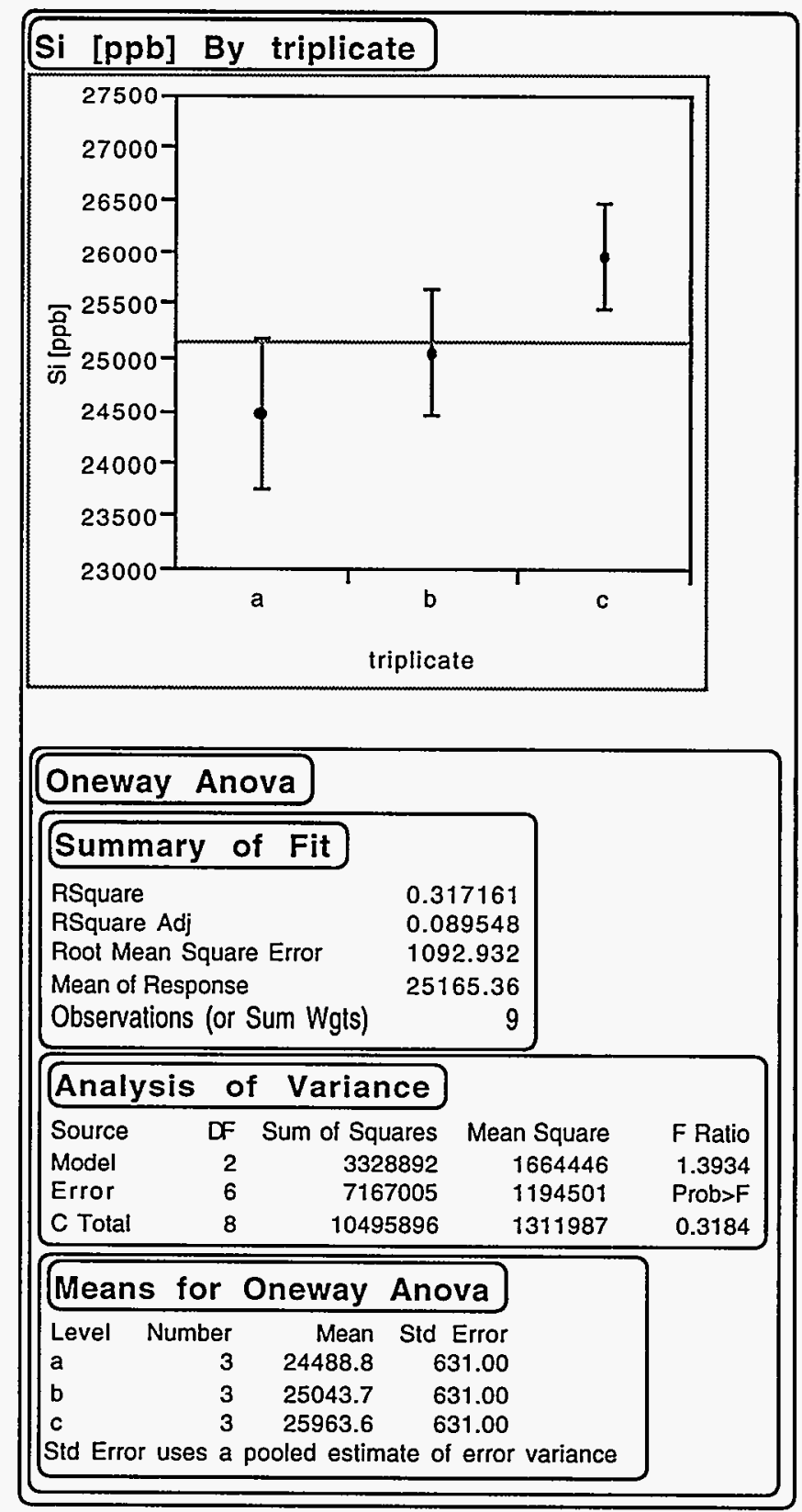


Figure G-5, contd. One-Way ANOVA for B Concentration in Leachates from 3-day, 1:1, $40^{\circ} \mathrm{C}$ Tests by Set of Triplicate Tests.

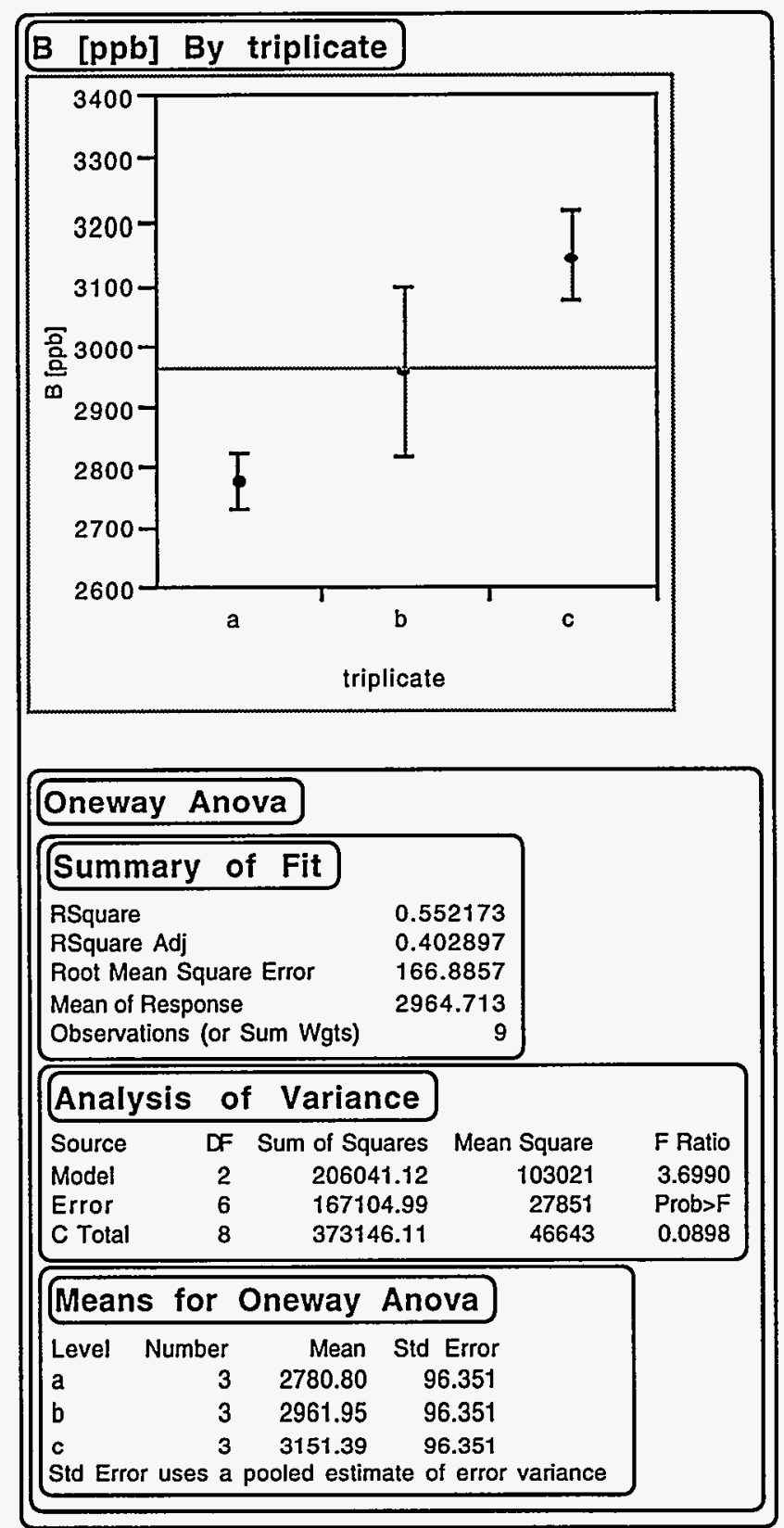


Figure G-6. One-Way ANOVA for Na Concentration in Leachates from 3-day, 1:1, 70 ${ }^{\circ} \mathrm{C}$ Tests by Set of Triplicate Tests.

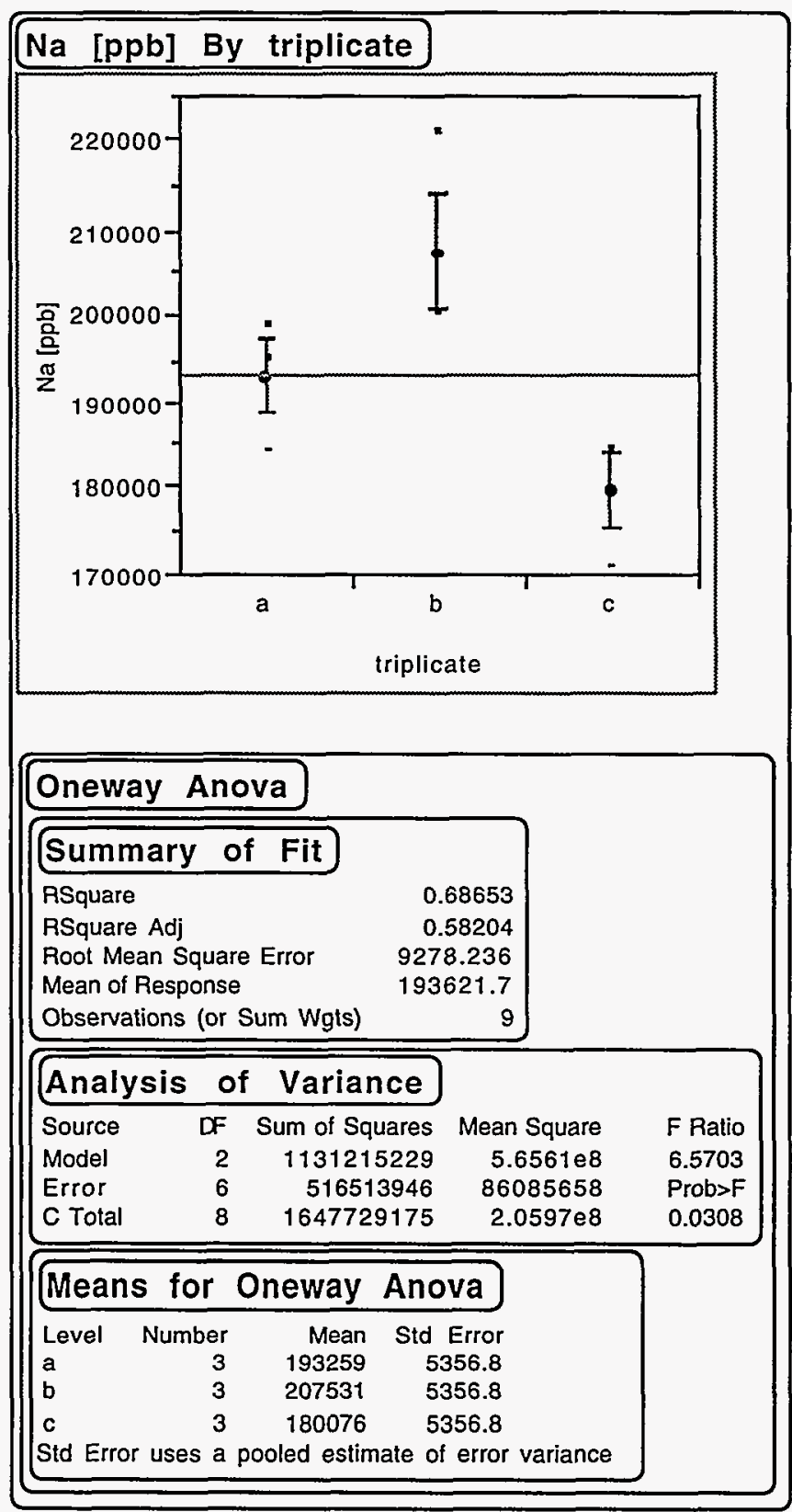


Figure G-6, contd. One-Way ANOVA for Si Concentration in Leachates from 3-day, 1:1, $70^{\circ} \mathrm{C}$ Tests by Set of Triplicate Tests.

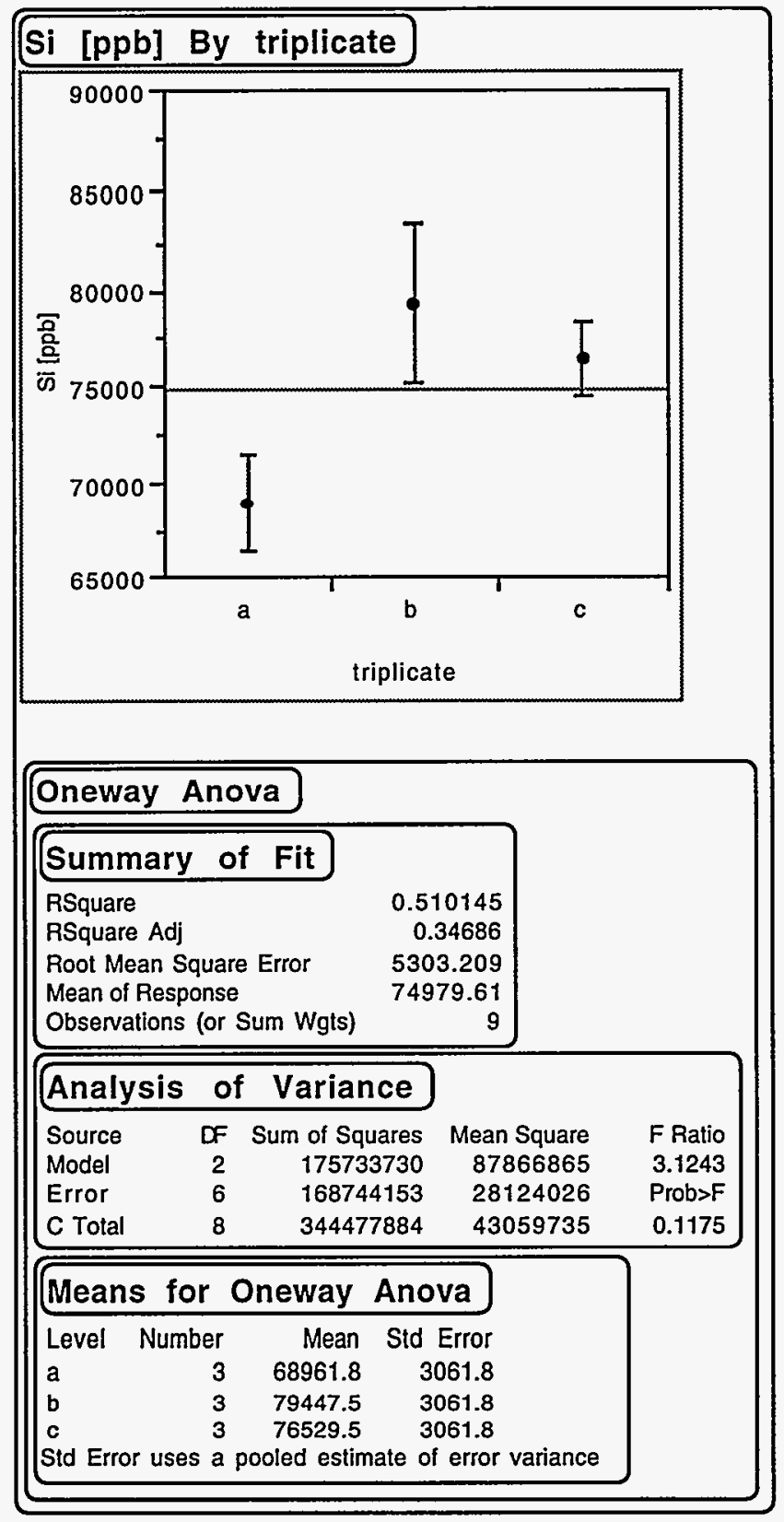


Figure G-6, contd. One-Way ANOVA for B Concentration in Leachates from 3-day, 1:1, 70 ${ }^{\circ} \mathrm{C}$ Tests by Set of Triplicate Tests.

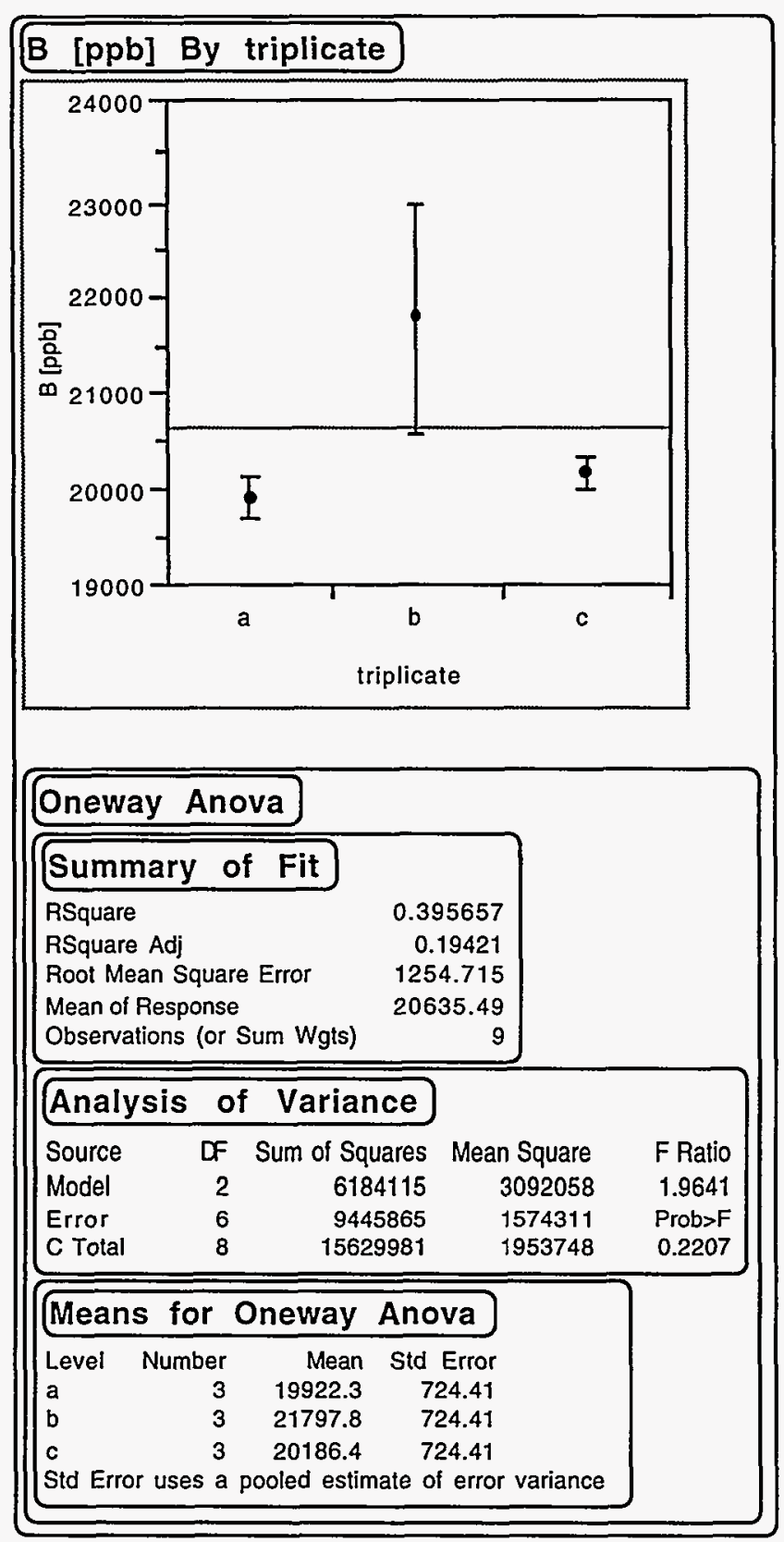


Figure G-7. One-Way ANOVA for Na Concentration in Leachates from 7-day, 1:10, $20^{\circ} \mathrm{C}$ Tests by Set of Triplicate Tests.

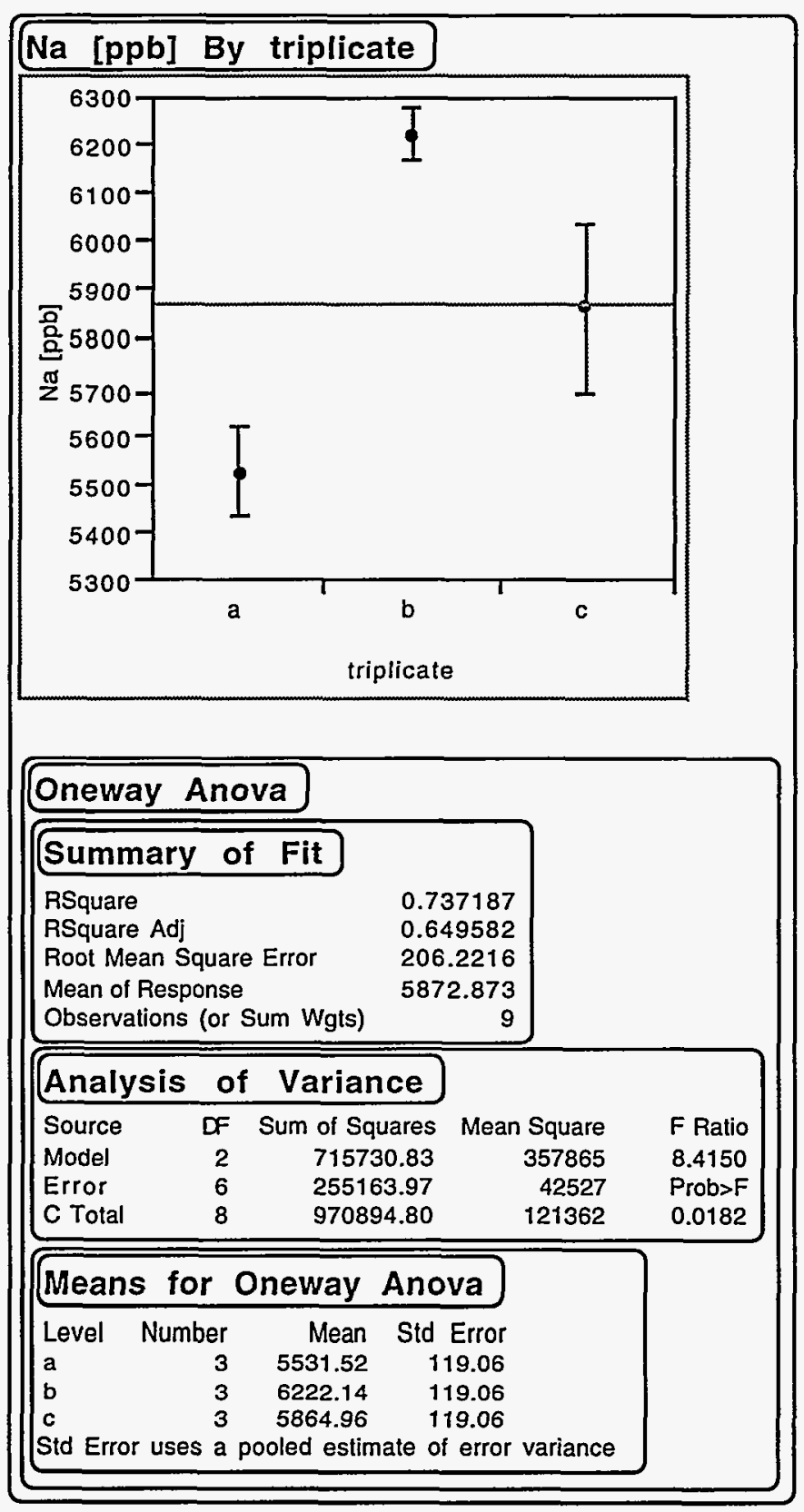


Figure G-7, contd. One-Way ANOVA for Si Concentration in Leachates from 7-day, 1:10, $20^{\circ} \mathrm{C}$ Tests by Set of Triplicate Tests.

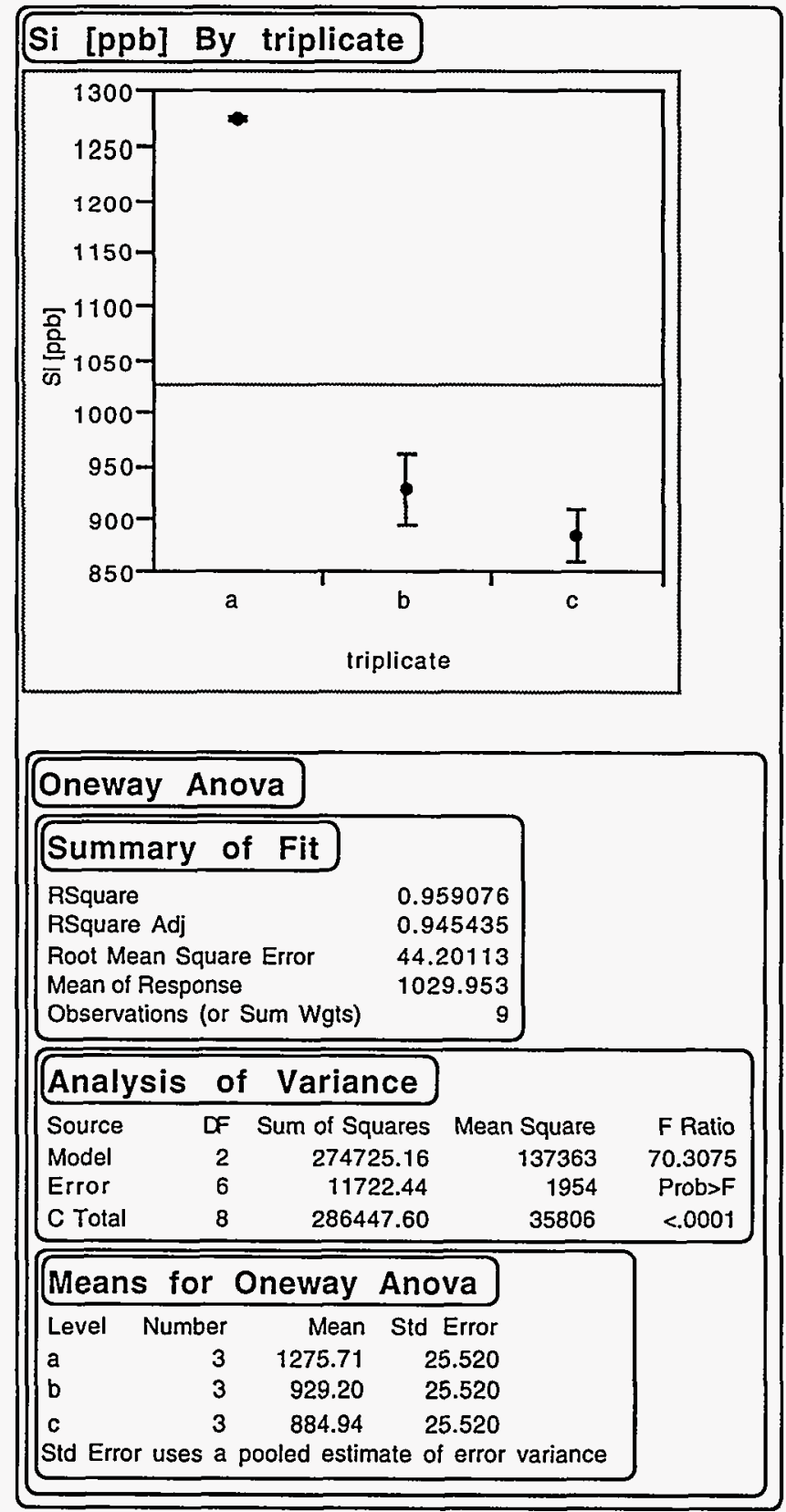


Figure G-7, contd. One-Way ANOVA for B Concentration in Leachates from 7-day, 1:10, $20^{\circ} \mathrm{C}$ Tests by Set of Triplicate Tests.

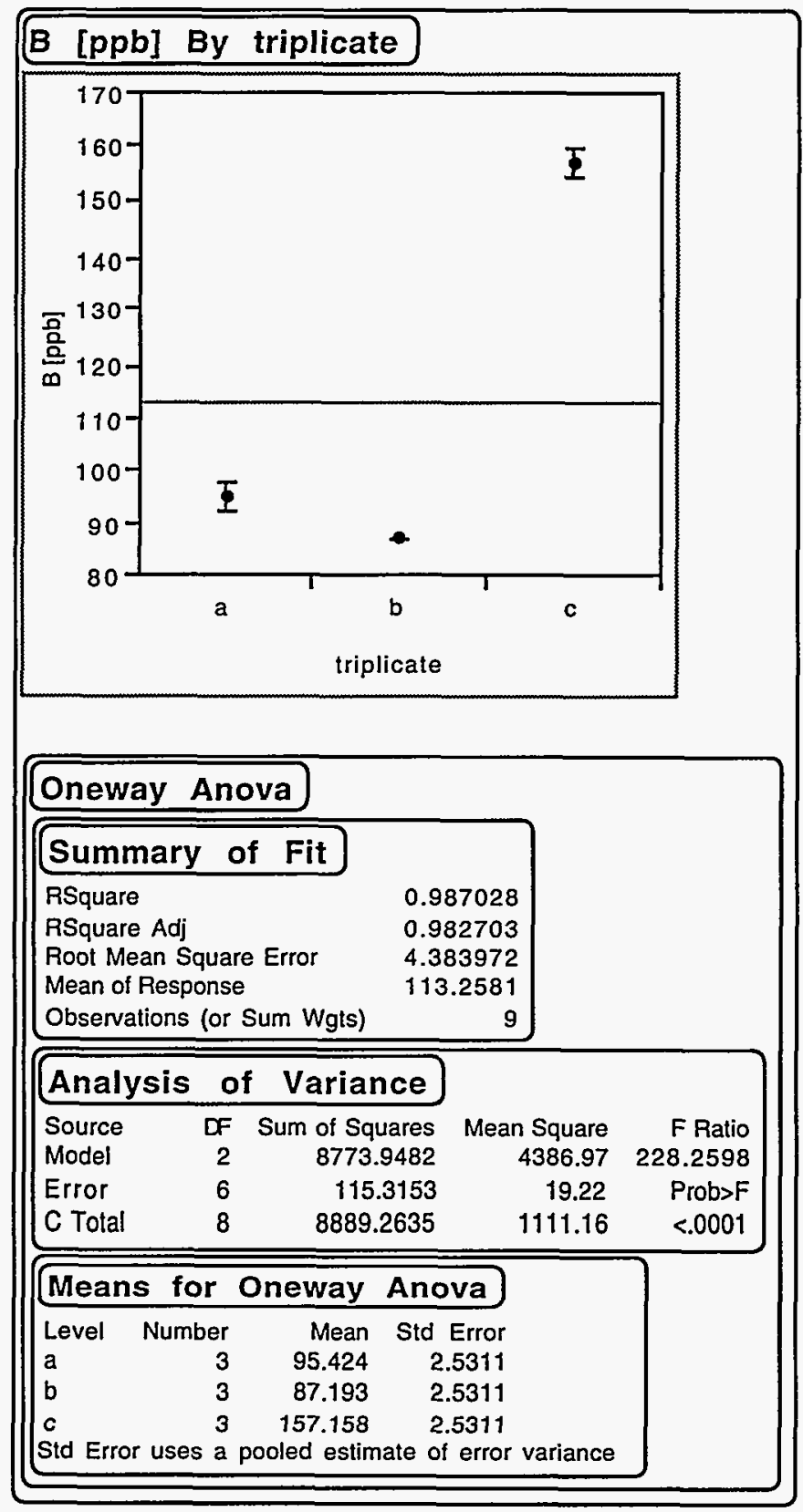


Figure G-8. One-Way ANOVA for Na Concentration in Leachates from 7-day, 1:10, $40^{\circ} \mathrm{C}$ Tests by Set of Triplicate Tests.

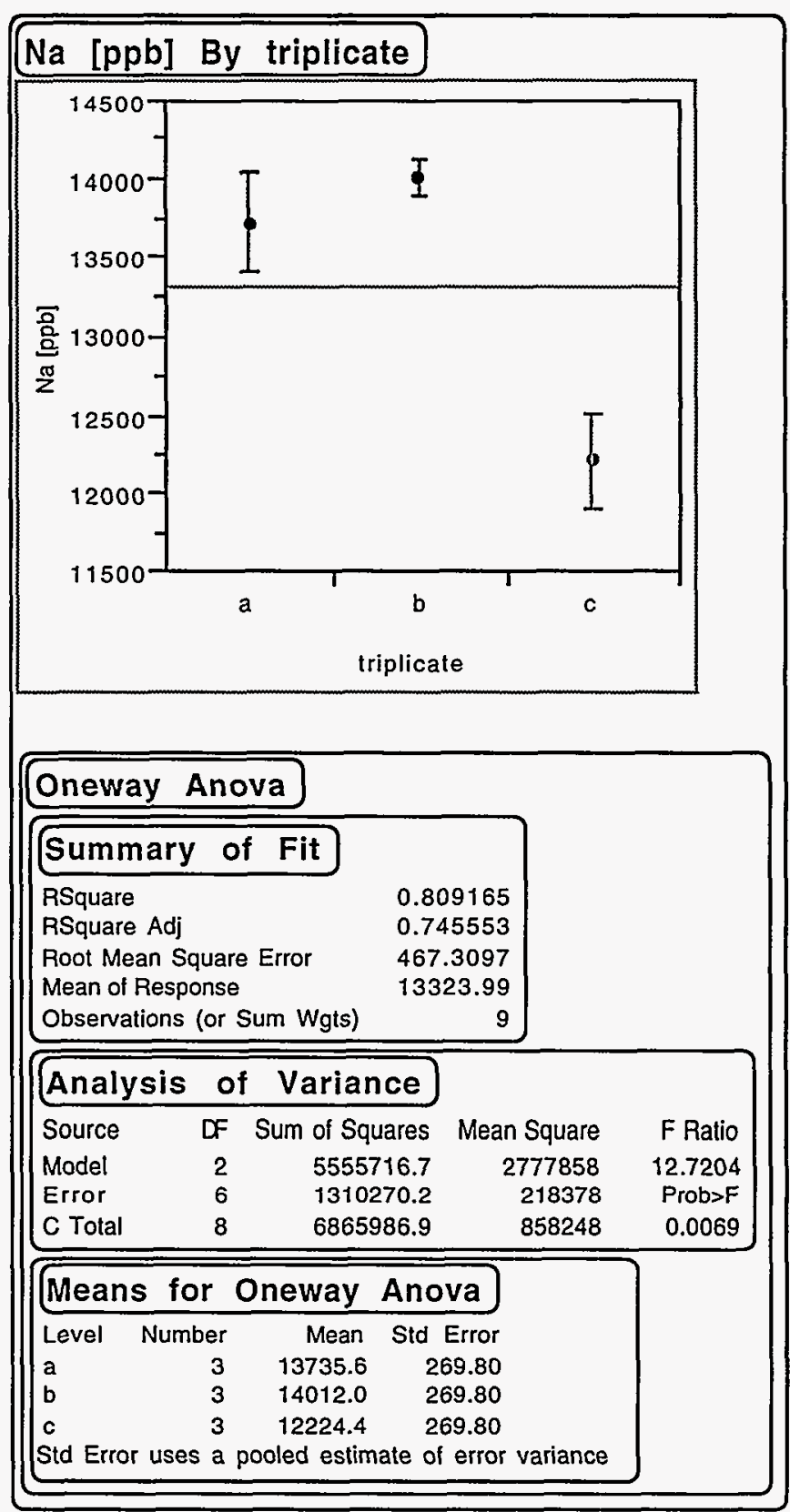


Figure G-8, contd. One-Way ANOVA for Si Concentration in Leachates from 7-day, 1:10, $40^{\circ} \mathrm{C}$ Tests by Set of Triplicate Tests.

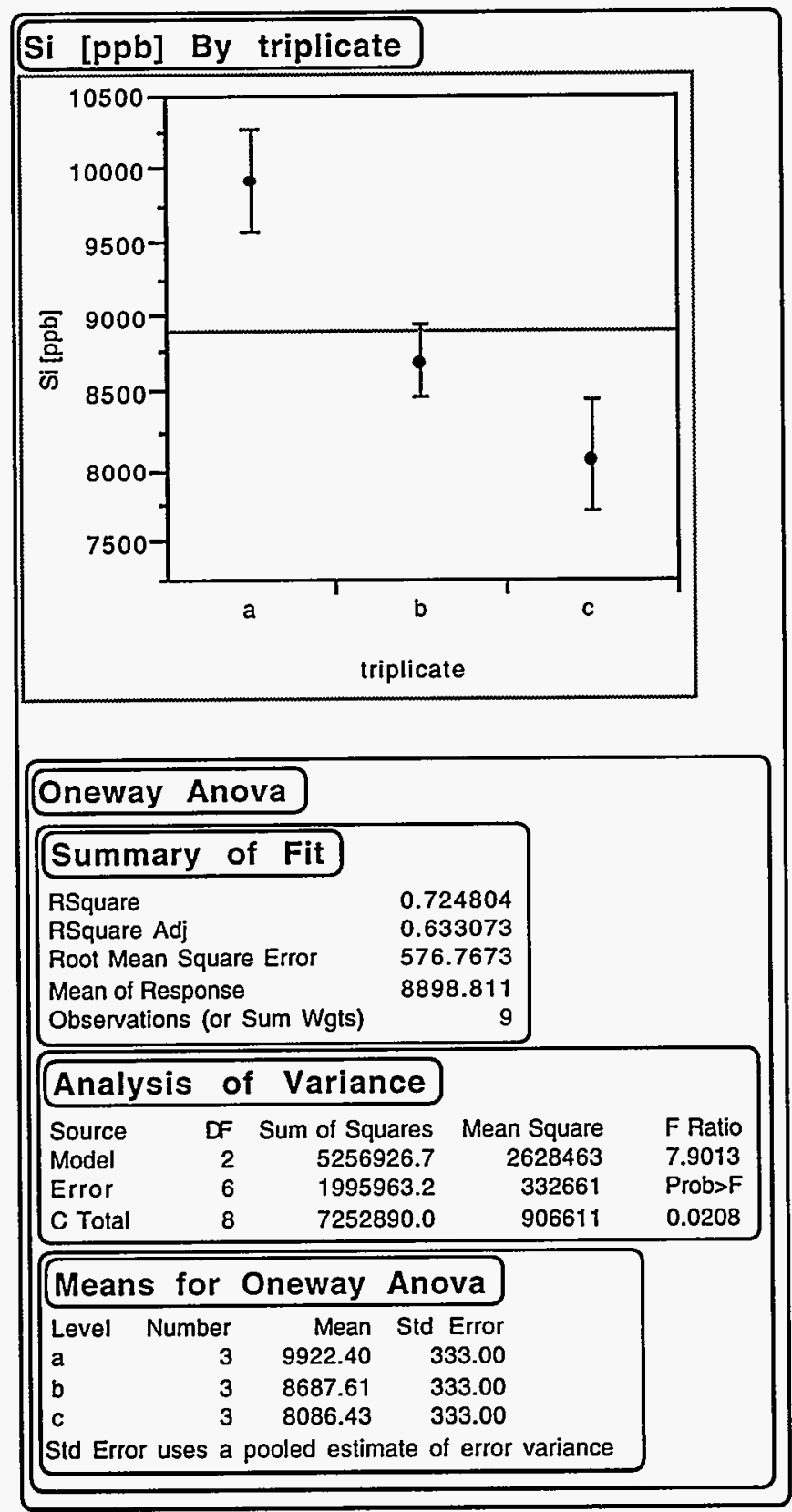


Figure G-8, contd. One-Way ANOVA for B Concentration in Leachates from 7-day, 1:10, $40^{\circ} \mathrm{C}$ Tests by Set of Triplicate Tests.

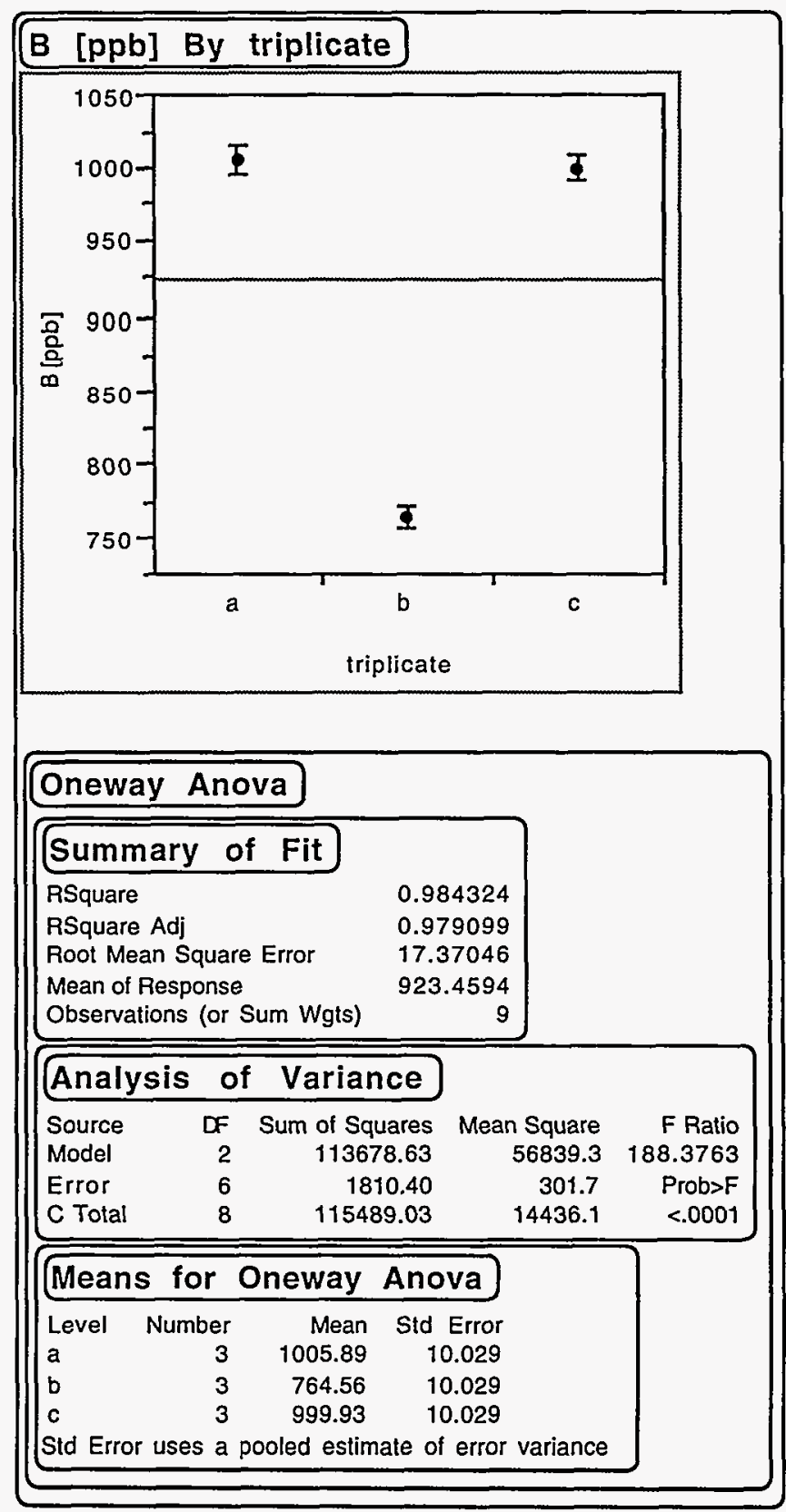


Figure G-9. One-Way ANOVA for Na Concentration in Leachates from 7-day, 1:10, $70^{\circ} \mathrm{C}$ Tests by Set of Triplicate Tests.

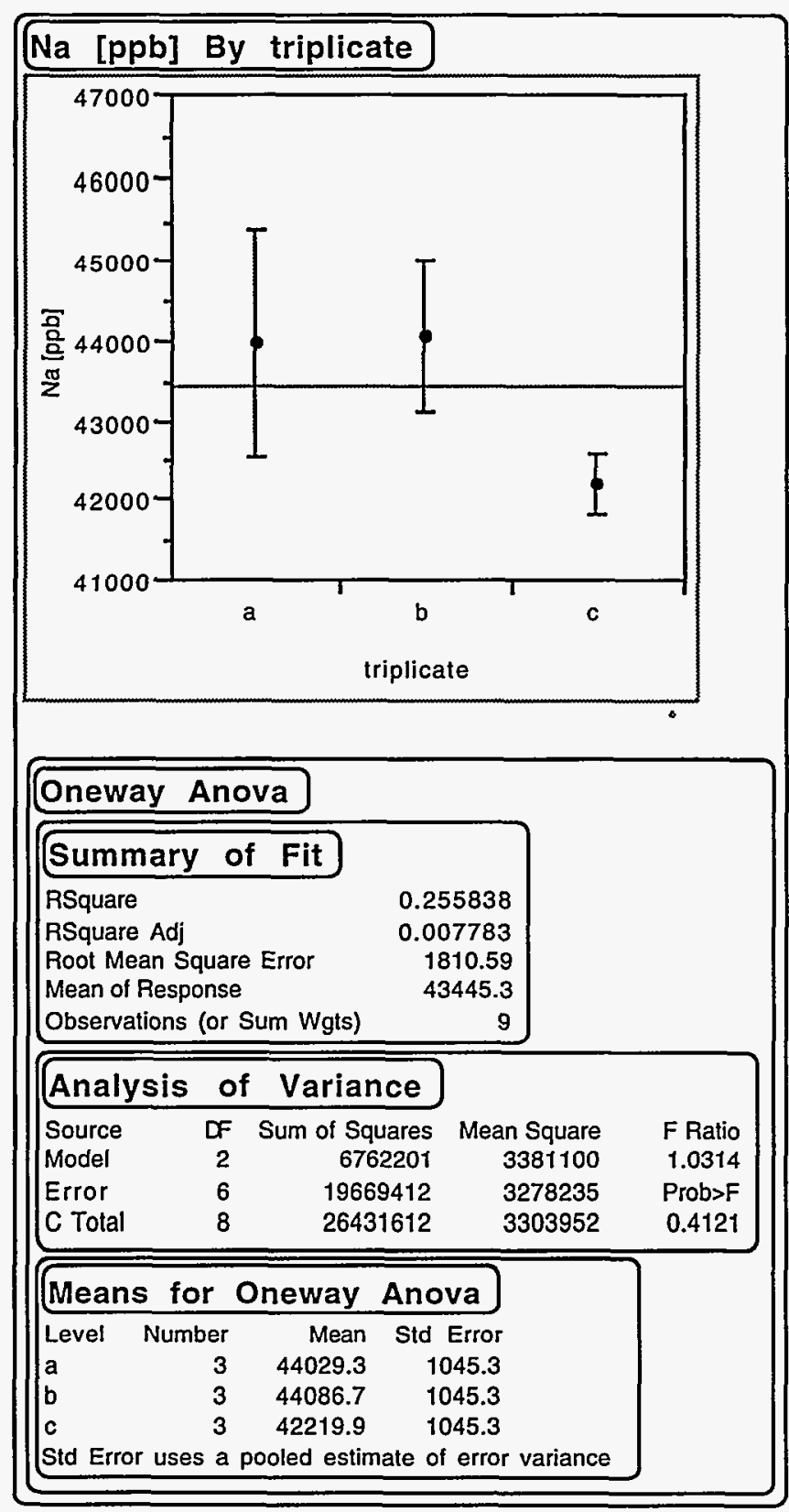


Figure G-9, contd. One-Way ANOVA for Si Concentration in Leachates from 7-day, 1:10, $70^{\circ} \mathrm{C}$ Tests by Set of Triplicate Tests.

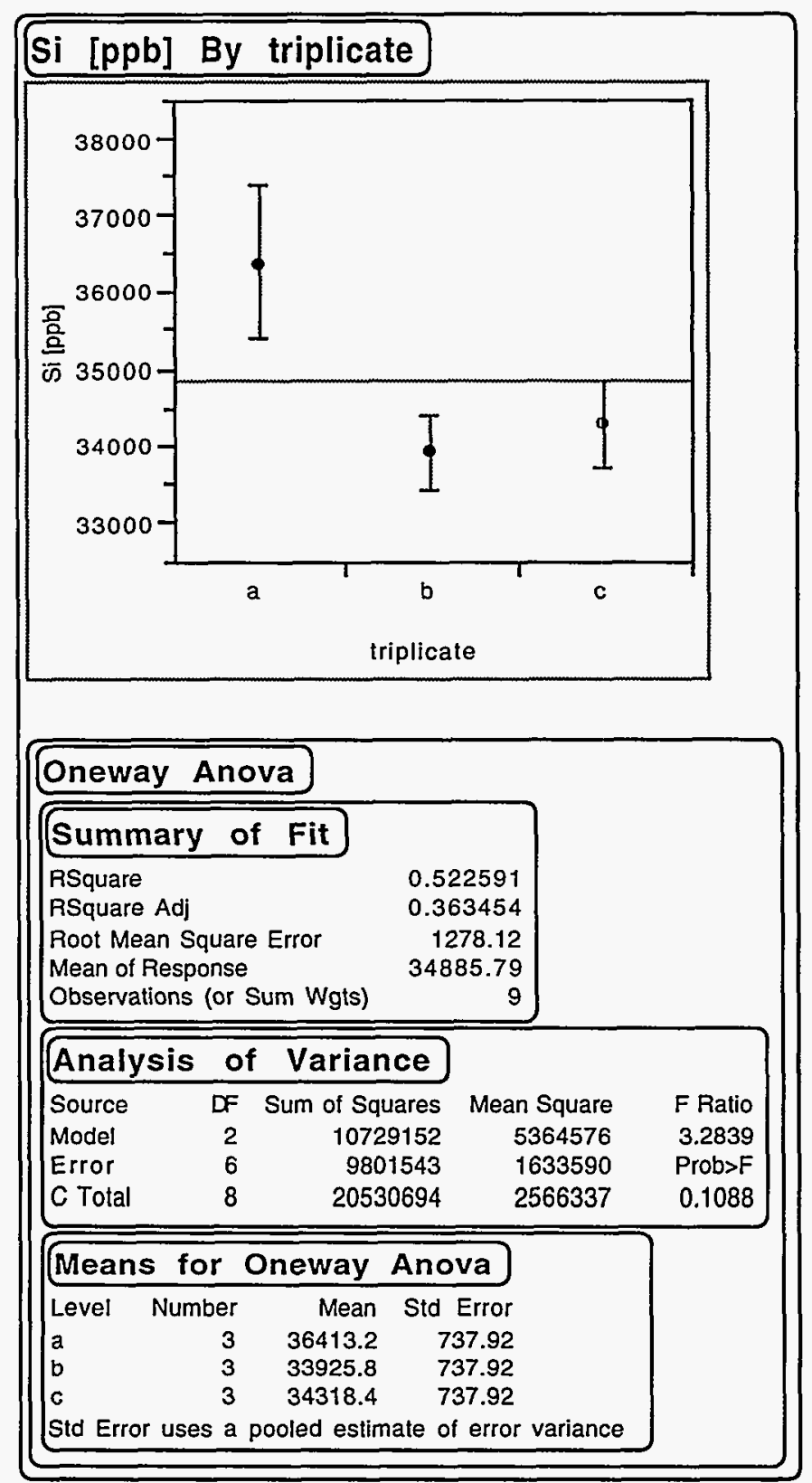


Figure G-9, contd. One-Way ANOVA for B Concentration in Leachates from 7-day, 1:10, $70^{\circ} \mathrm{C}$ Tests by Set of Triplicate Tests.

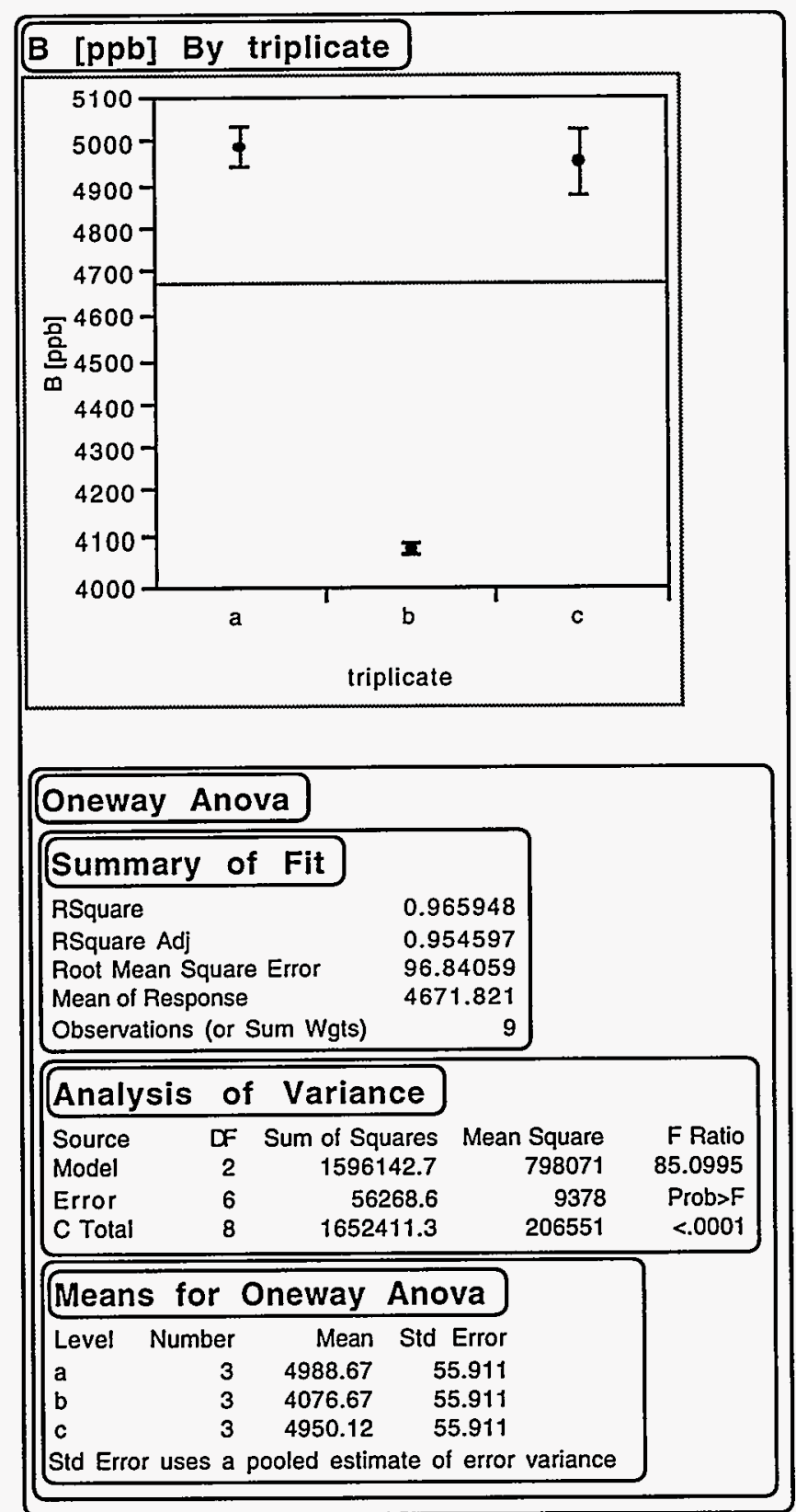


Figure G-10. One-Way ANOVA for Na Concentration in Leachates from 7-day, 1:1, $20^{\circ} \mathrm{C}$ Tests by Set of Triplicate Tests.

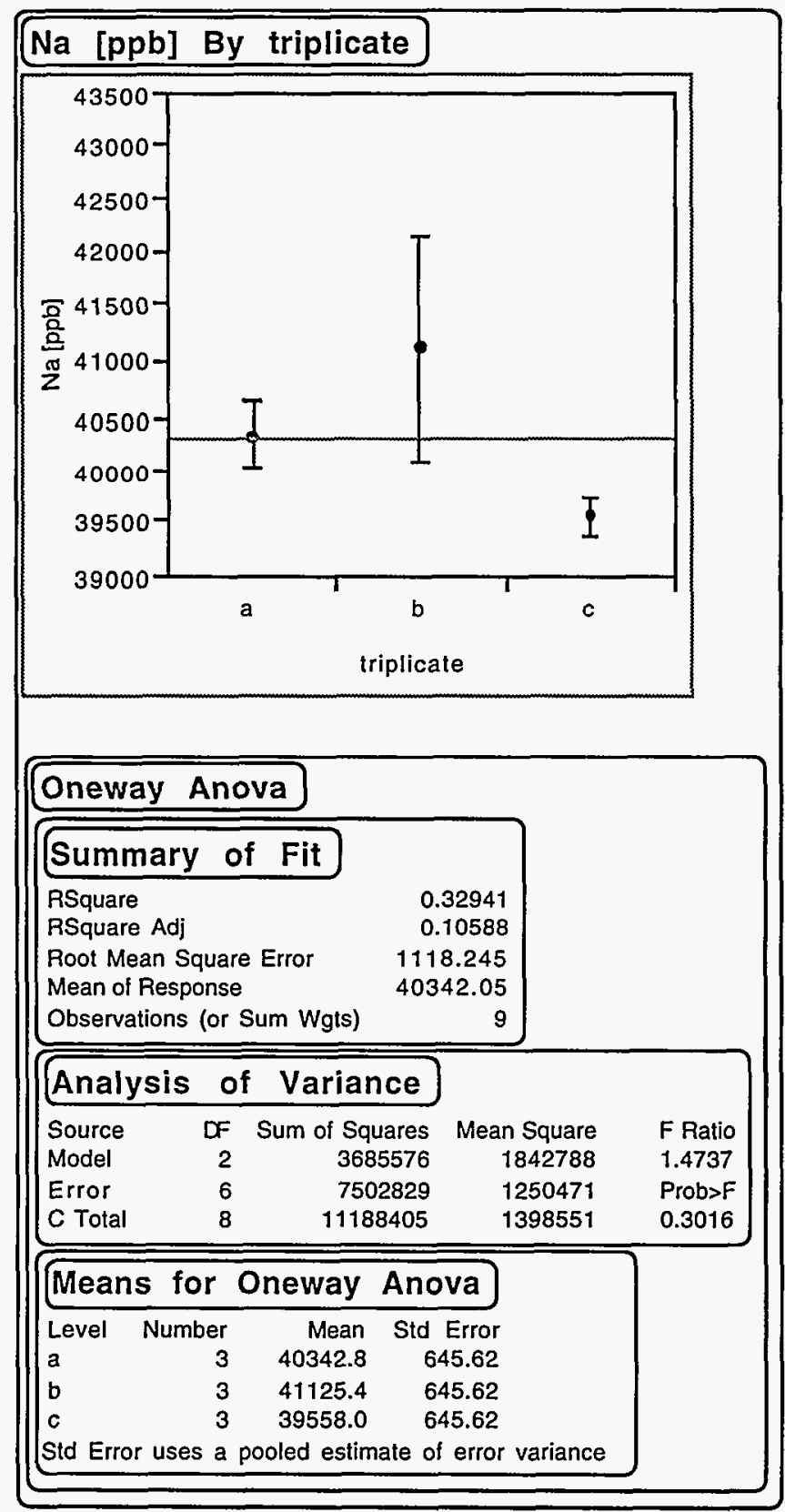


Figure G-10, contd. One-Way ANOVA for Si Concentration in Leachates from 7-day, 1:1, 20 ${ }^{\circ} \mathrm{C}$ Tests by Set of Triplicate Tests.

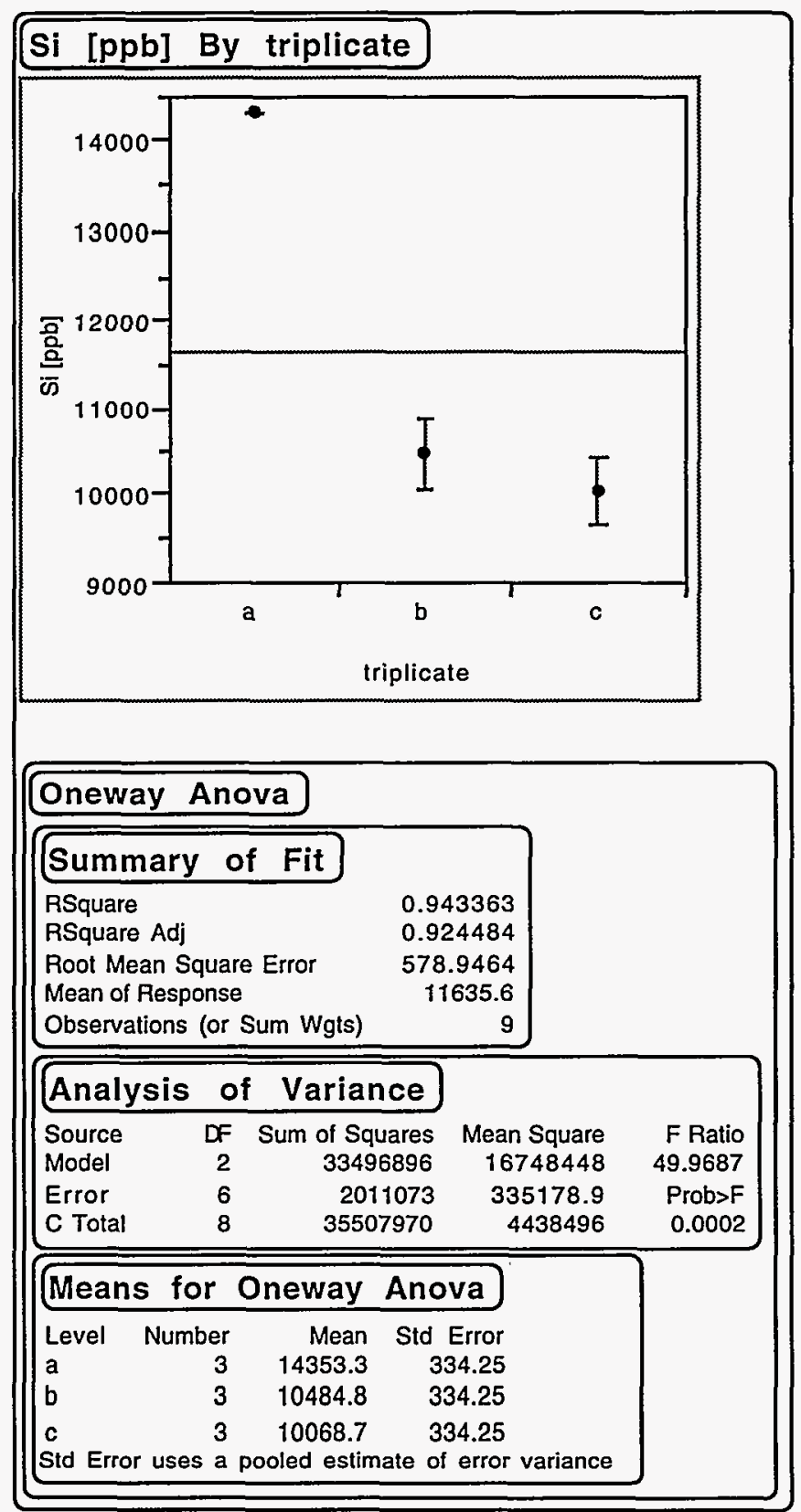


Figure G-10, contd. One-Way ANOVA for B Concentration in Leachates from 7-day, 1:1, $20^{\circ} \mathrm{C}$ Tests by Set of Triplicate Tests.

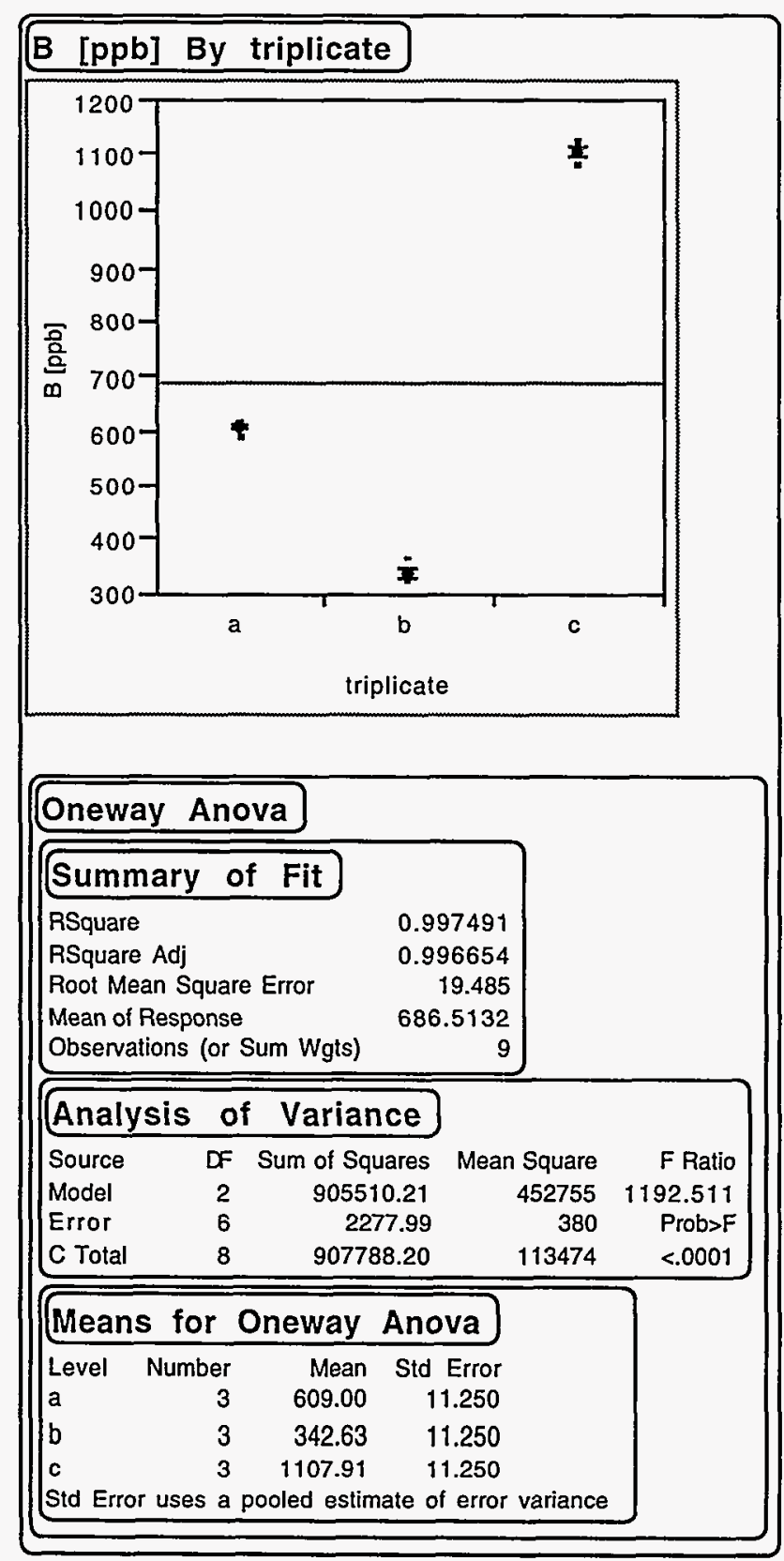


Figure G-11. One-Way ANOVA for Na Concentration in Leachates from 7-day, 1:1, 40 ${ }^{\circ} \mathrm{C}$ Tests by Set of Triplicate Tests.

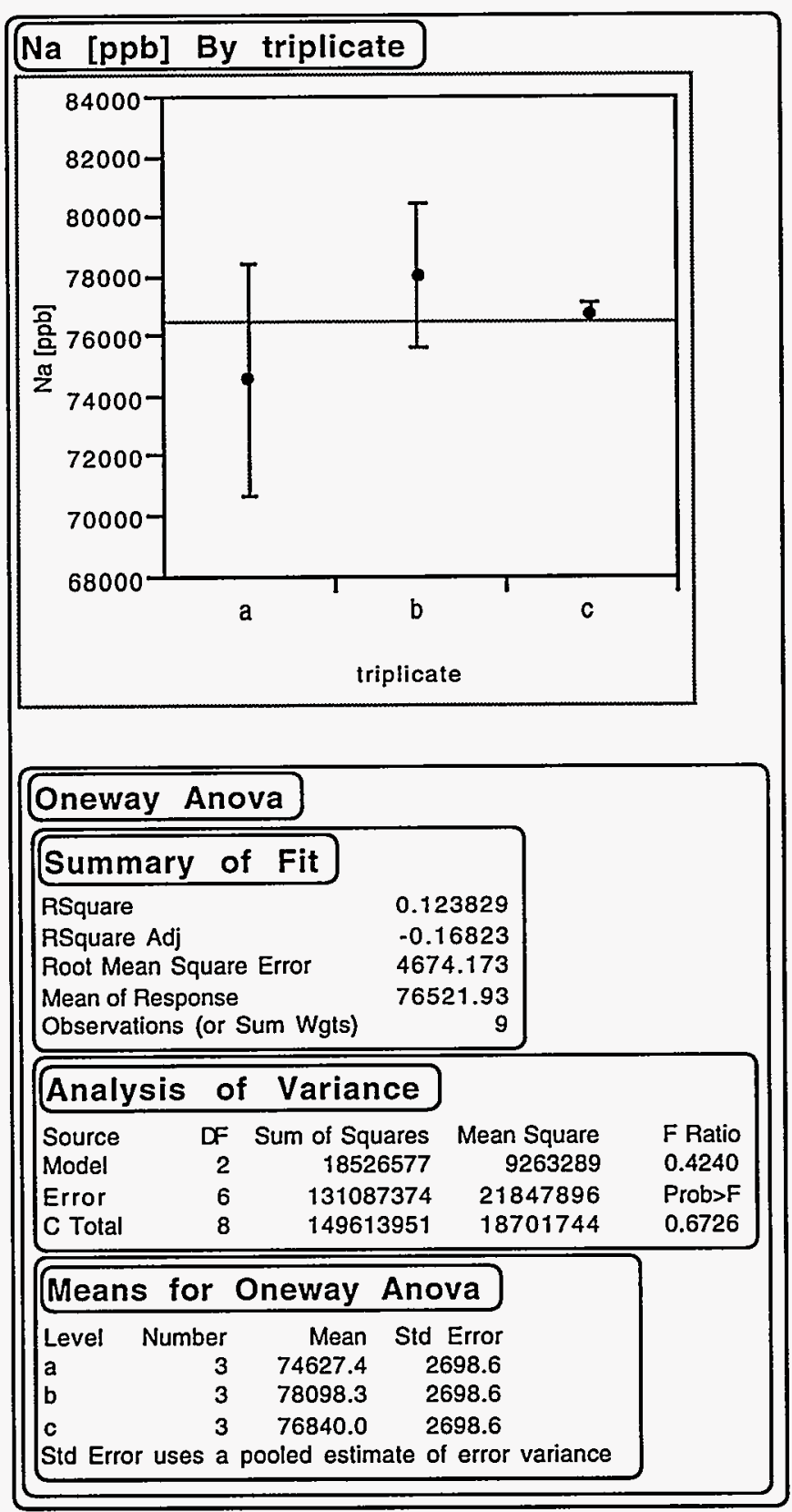


Figure G-11, contd. One-Way ANOVA for Si Concentration in Leachates from 7-day, 1:1, $40^{\circ} \mathrm{C}$ Tests by Set of Triplicate Tests.

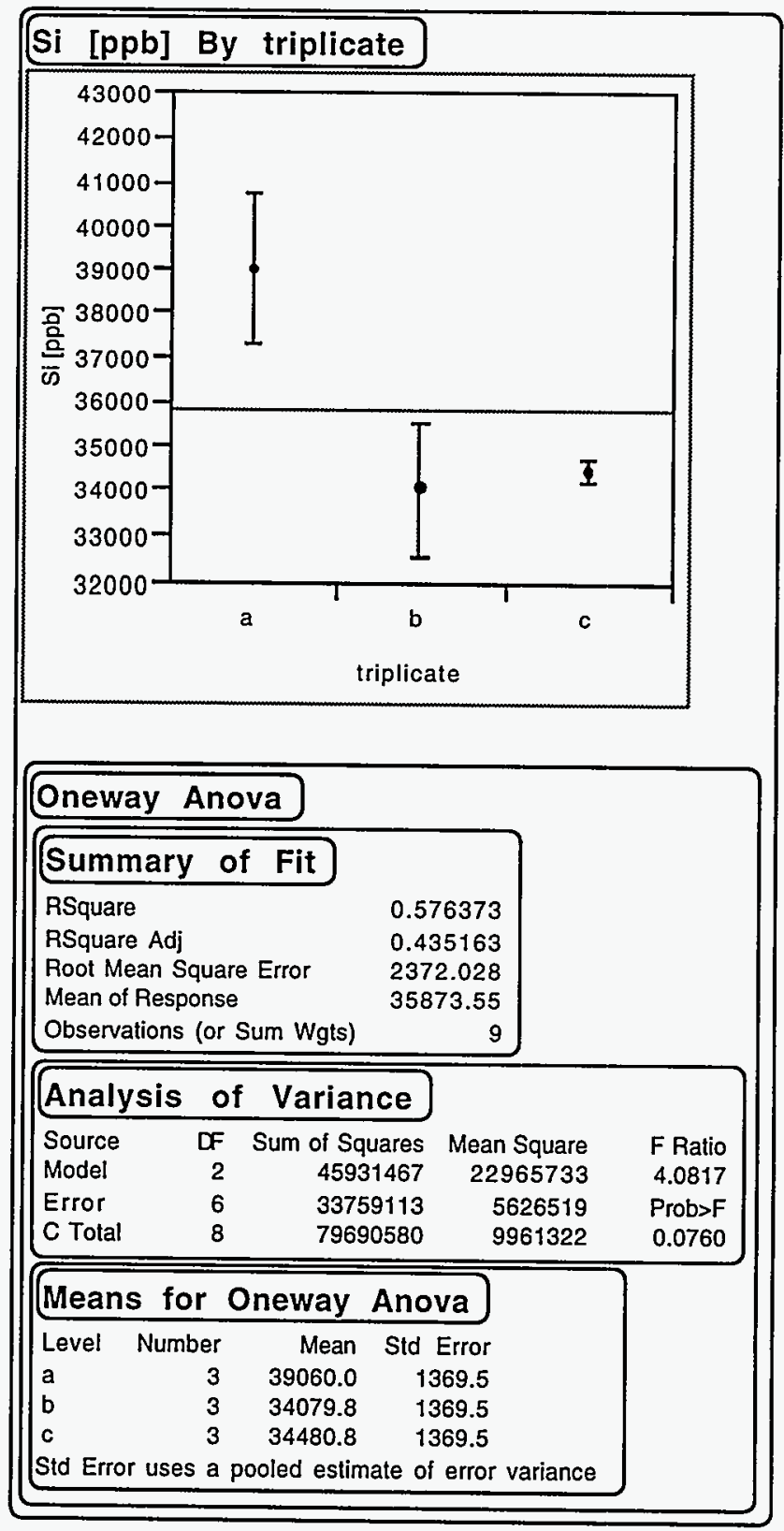


Figure G-11, contd. One-Way ANOVA for B Concentration in Leachates from 7-day, 1:1, $40^{\circ} \mathrm{C}$ Tests by Set of Triplicate Tests.

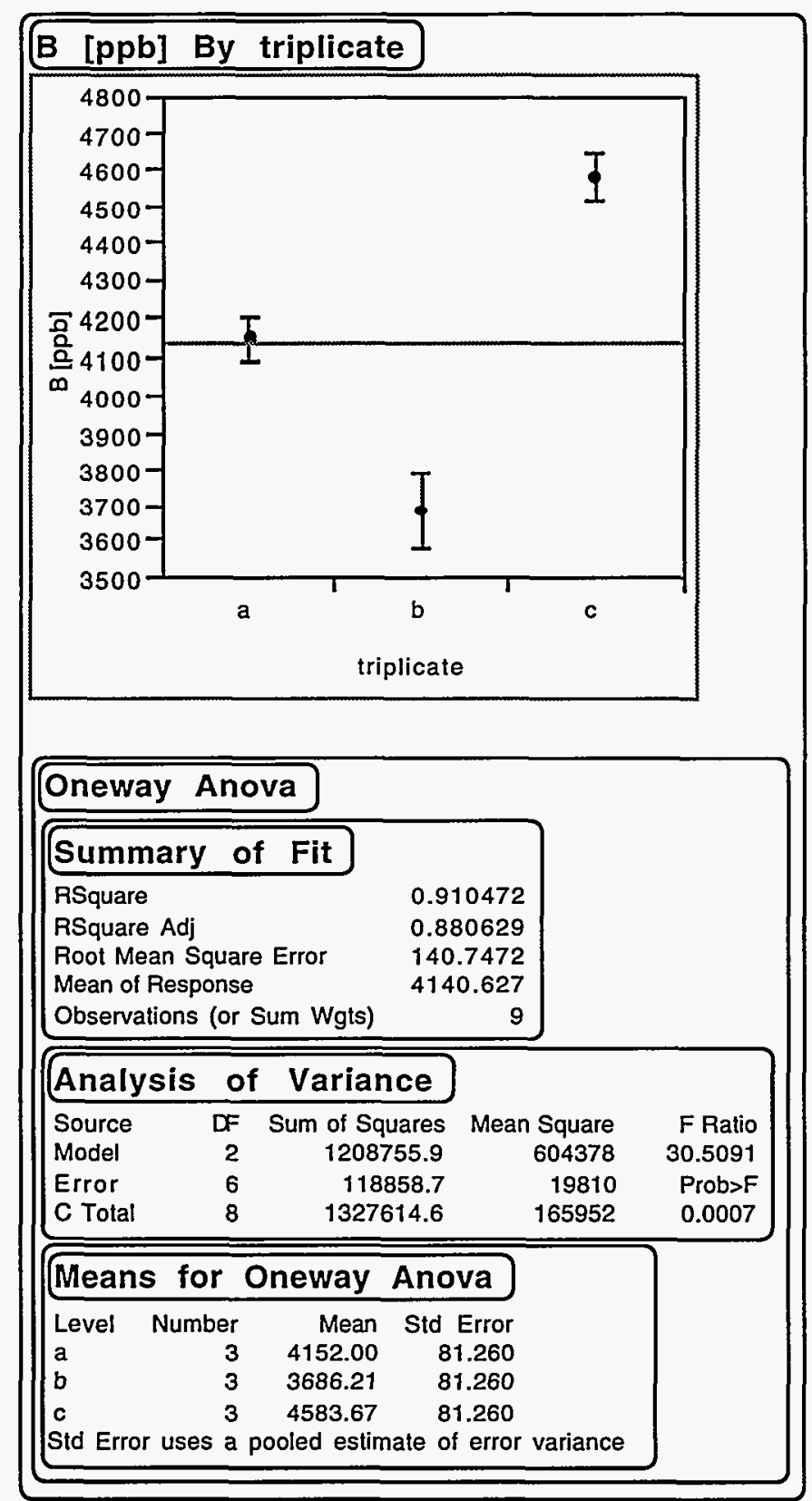


Figure G-12. One-Way ANOVA for Na Concentration in Leachates from 7-day, $1: 1,70^{\circ} \mathrm{C}$ Tests by Set of Triplicate Tests.

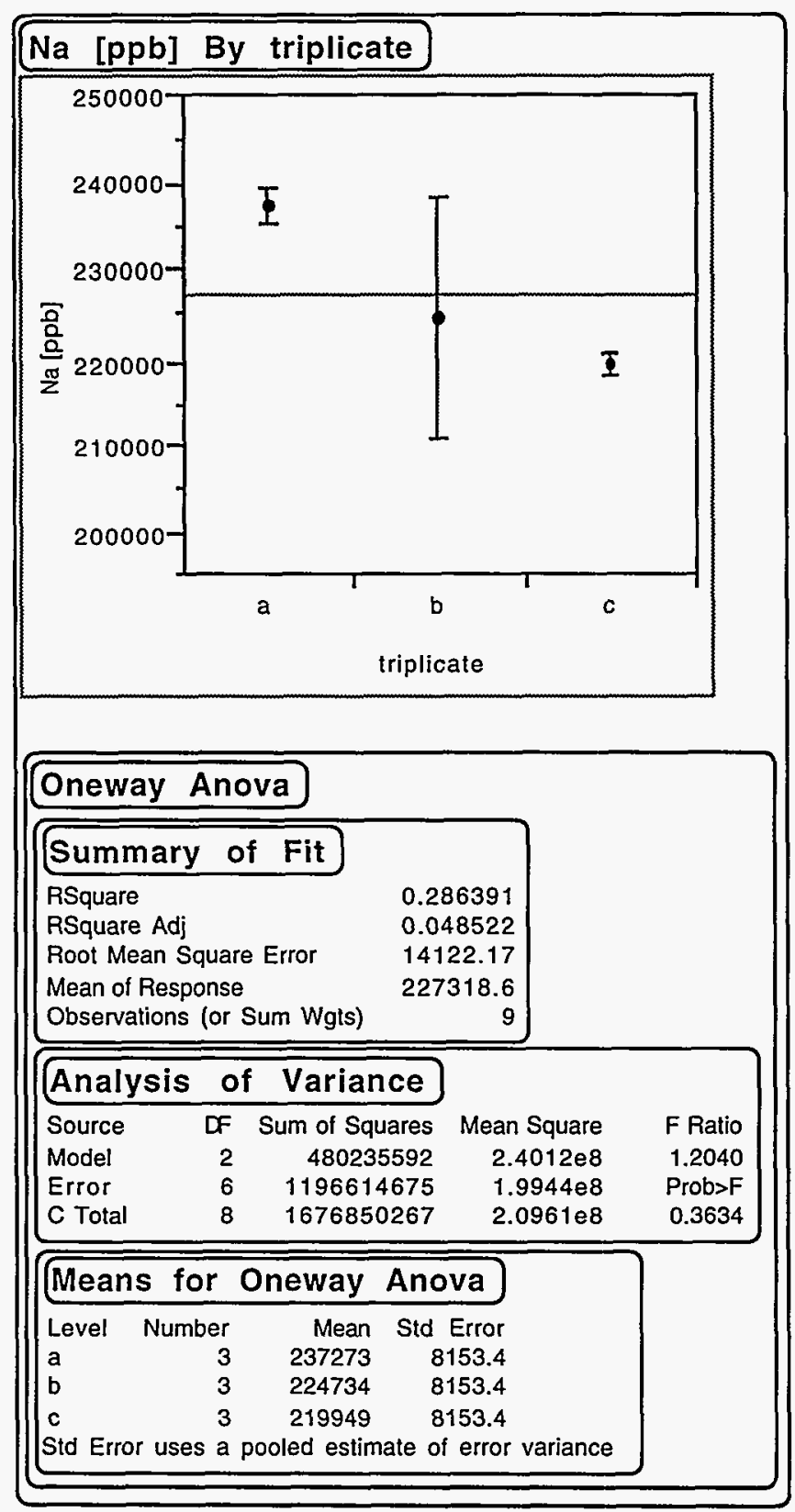


Figure G-12, contd. One-Way ANOVA for Si Concentration in Leachates from 7-day, 1:1, 70 ${ }^{\circ} \mathrm{C}$ Tests by Set of Triplicate Tests.

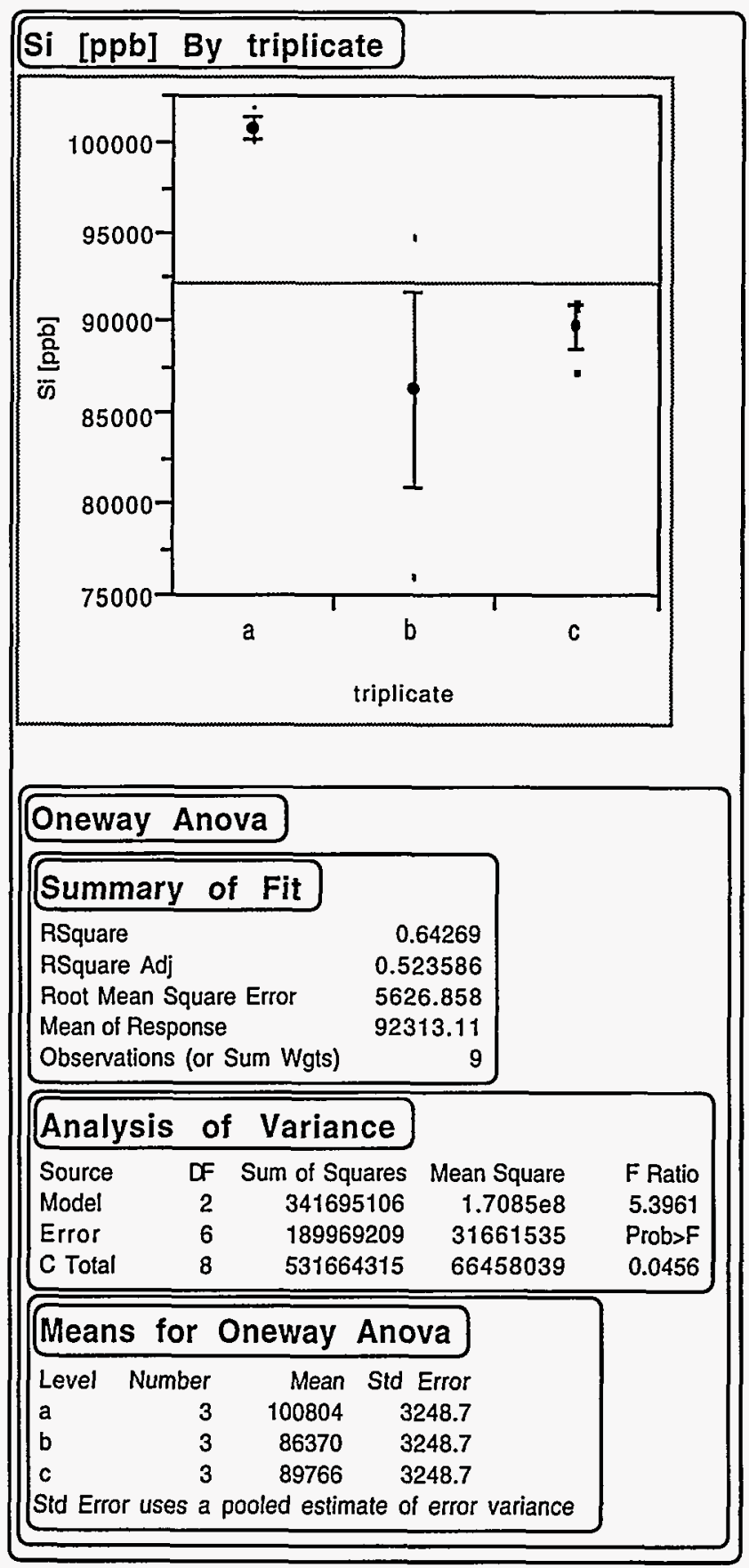


Figure G-12, contd. One-Way ANOVA for B Concentration in Leachates from 7-day, 1:1, 70 ${ }^{\circ} \mathrm{C}$ Tests by Set of Triplicate Tests.

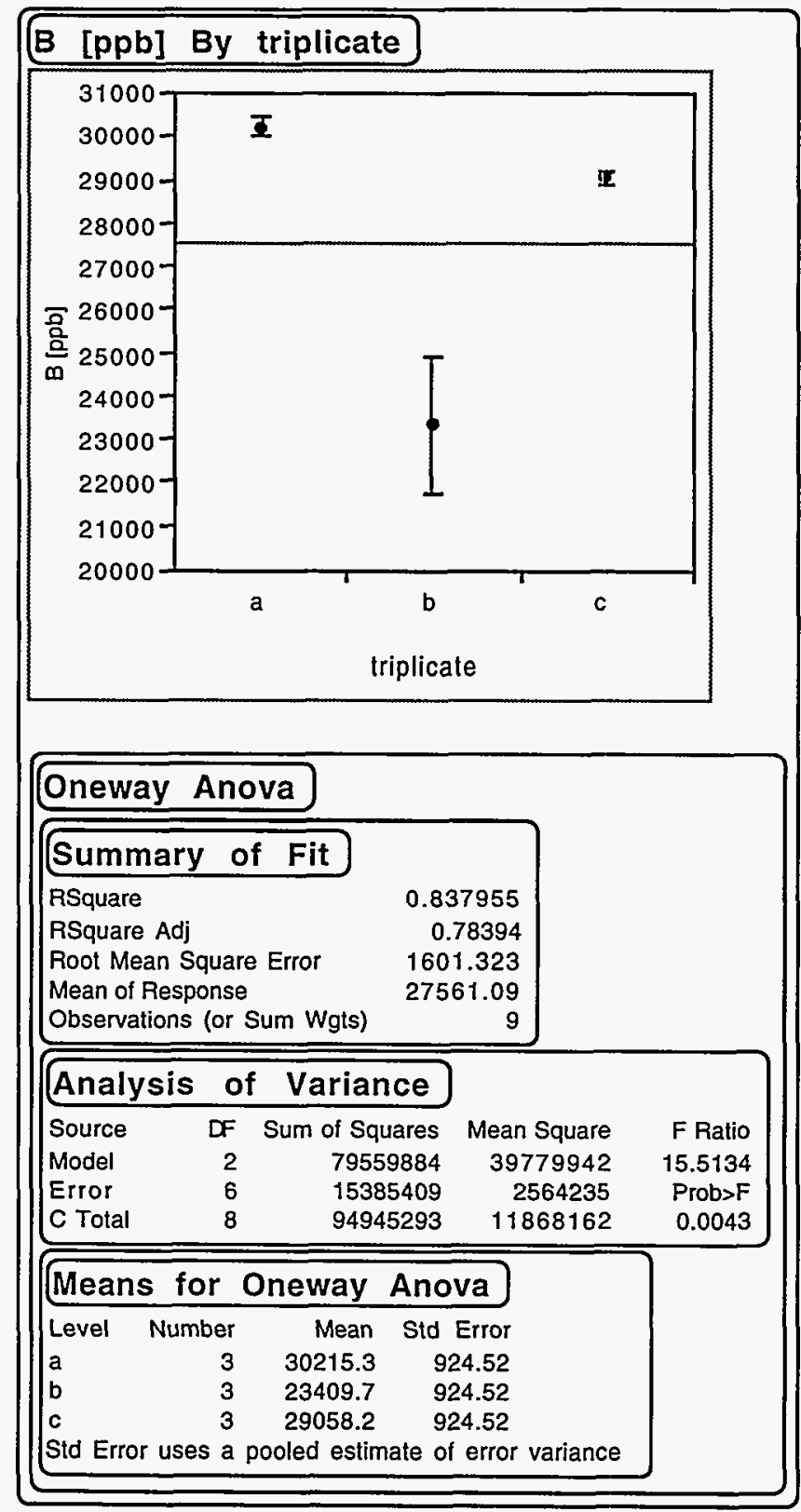




\section{APPENDIX H. ANALYSIS OF VARIANCE BY REPLICATE ANALYSIS}

Figure $\mathrm{H}-1$. One-Way ANOVA for Na Concentration in Leachates from 3-day, $40^{\circ} \mathrm{C}, 1: 10$ Tests by Replicate.

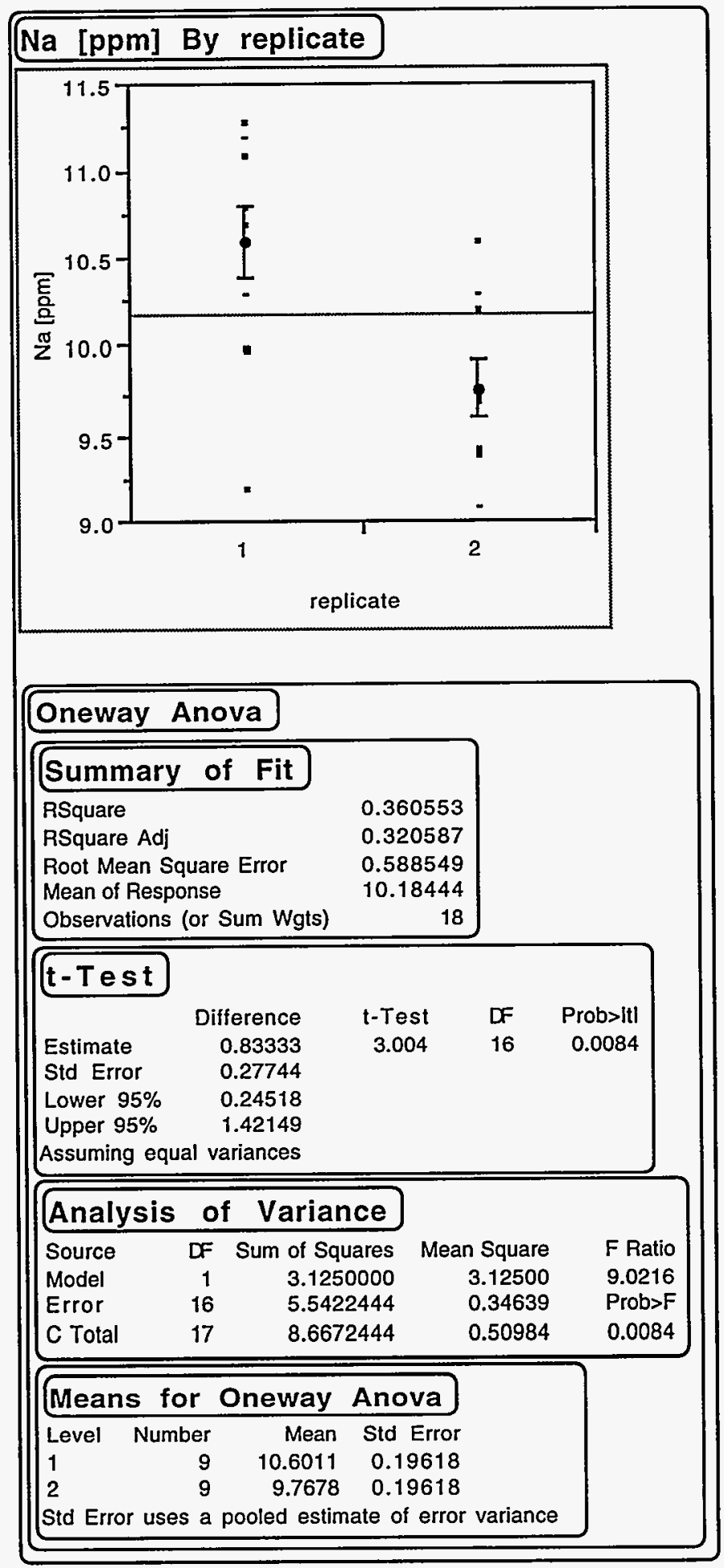


Figure $\mathrm{H}-1$, contd. One-Way ANOVA for Si Concentration in Leachates from 3 -day, $40^{\circ} \mathrm{C}, 1: 10$ Tests by Replicate.

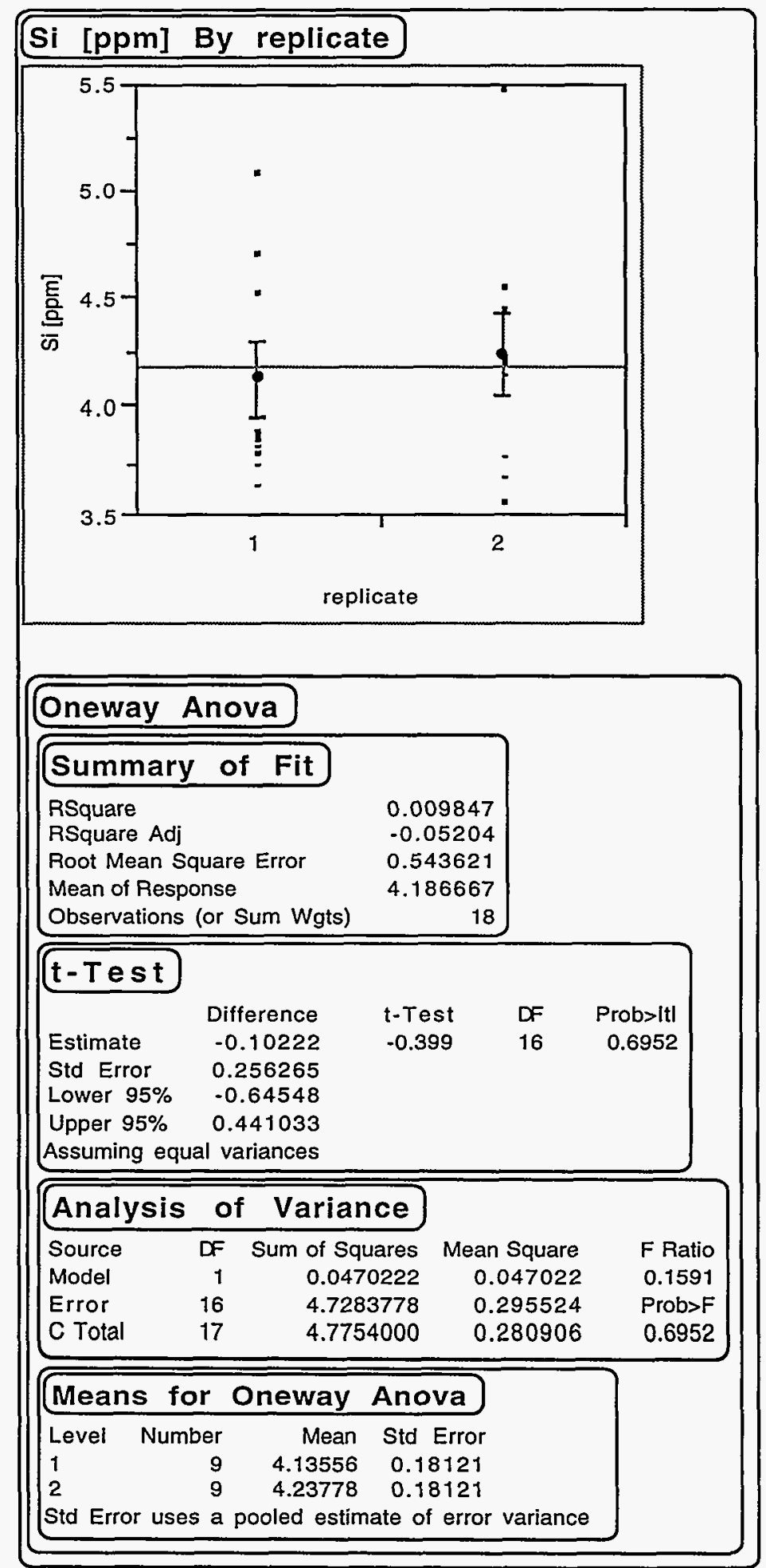


Figure $\mathrm{H}-2$. One-Way ANOVA for Na Concentration in Leachates from 3-day, $70^{\circ} \mathrm{C}, 1: 10$ Tests by Replicate.

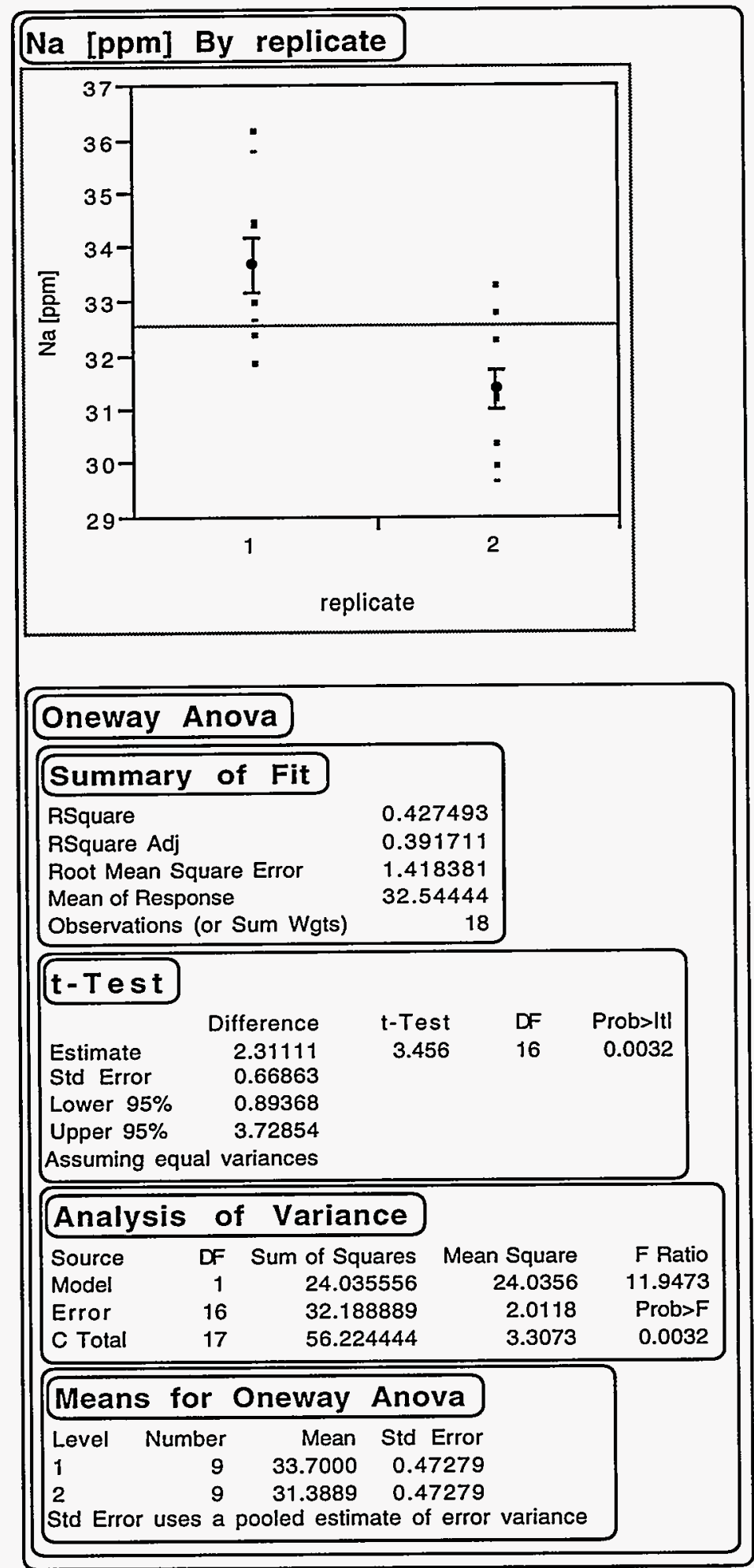


Figure $\mathrm{H}-2$, contd. One-Way ANOVA for Si Concentration in Leachates from 3-day, 70 ${ }^{\circ} \mathrm{C}, 1: 10$ Tests by Replicate.

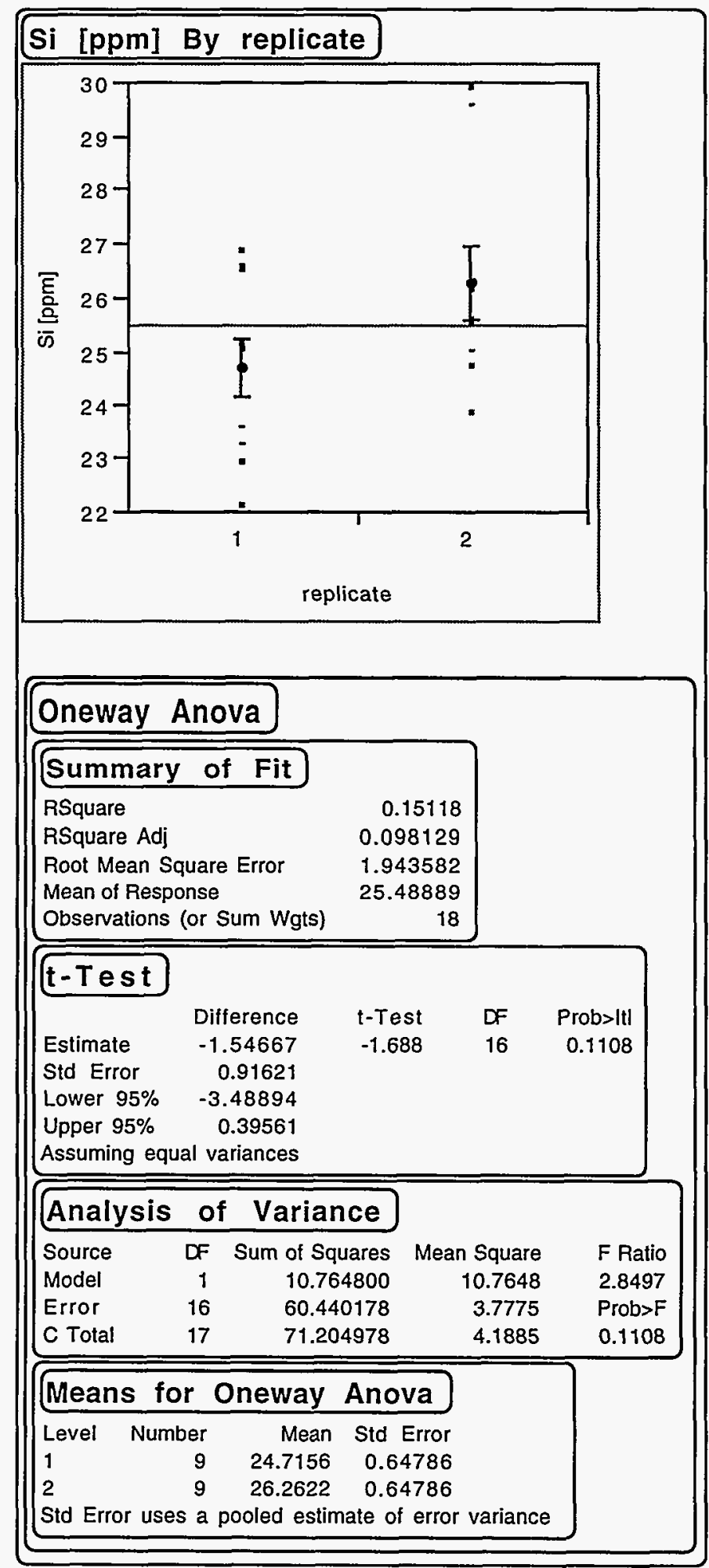


Figure H-3. One-Way ANOVA for $\mathrm{Na}$ Concentration in Leachates from 7-day, $40^{\circ} \mathrm{C}, 1: 10$ Tests by Replicate.

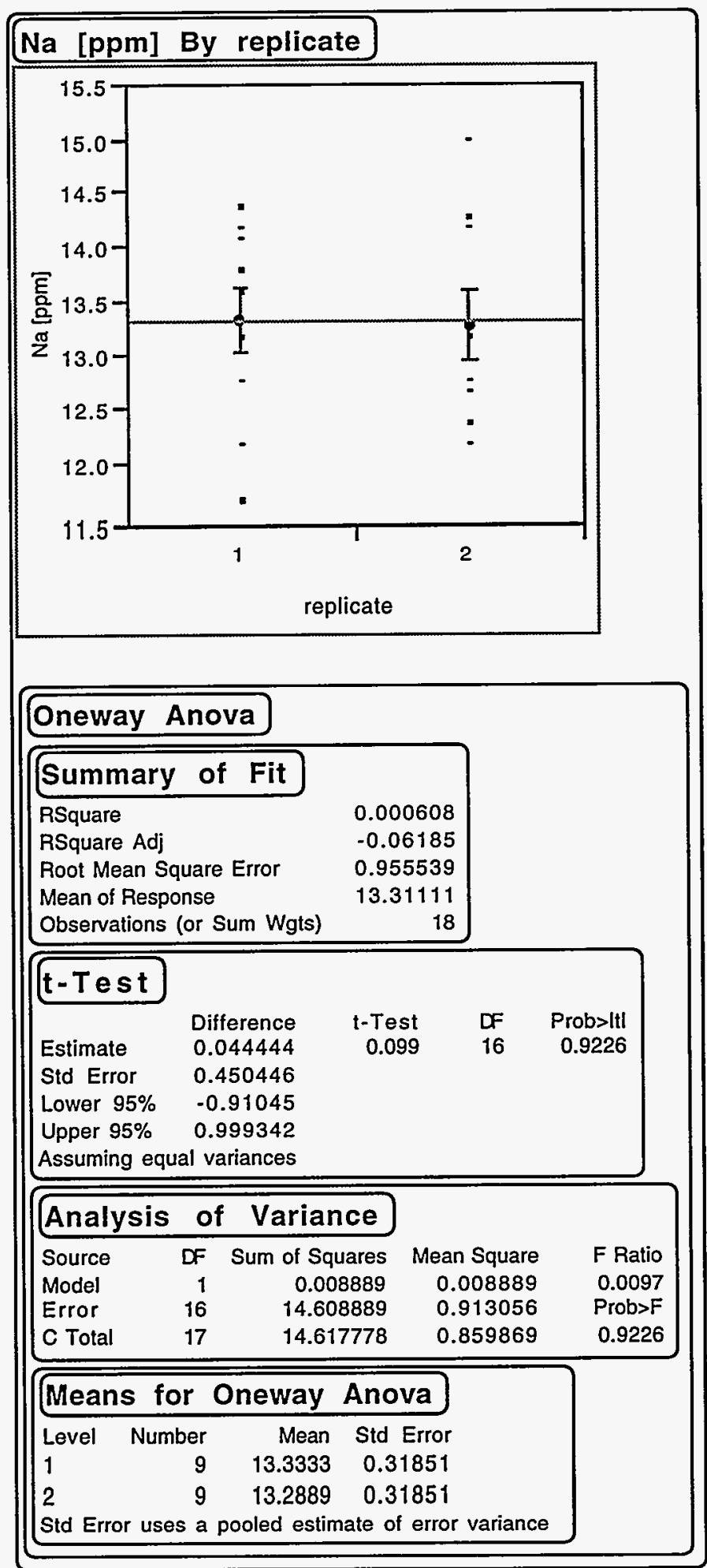


Figure $\mathrm{H}-3$, contd. One-Way ANOVA for Si Concentration in Leachates from 7-day, $40^{\circ} \mathrm{C}, 1: 10$ Tests by Replicate.

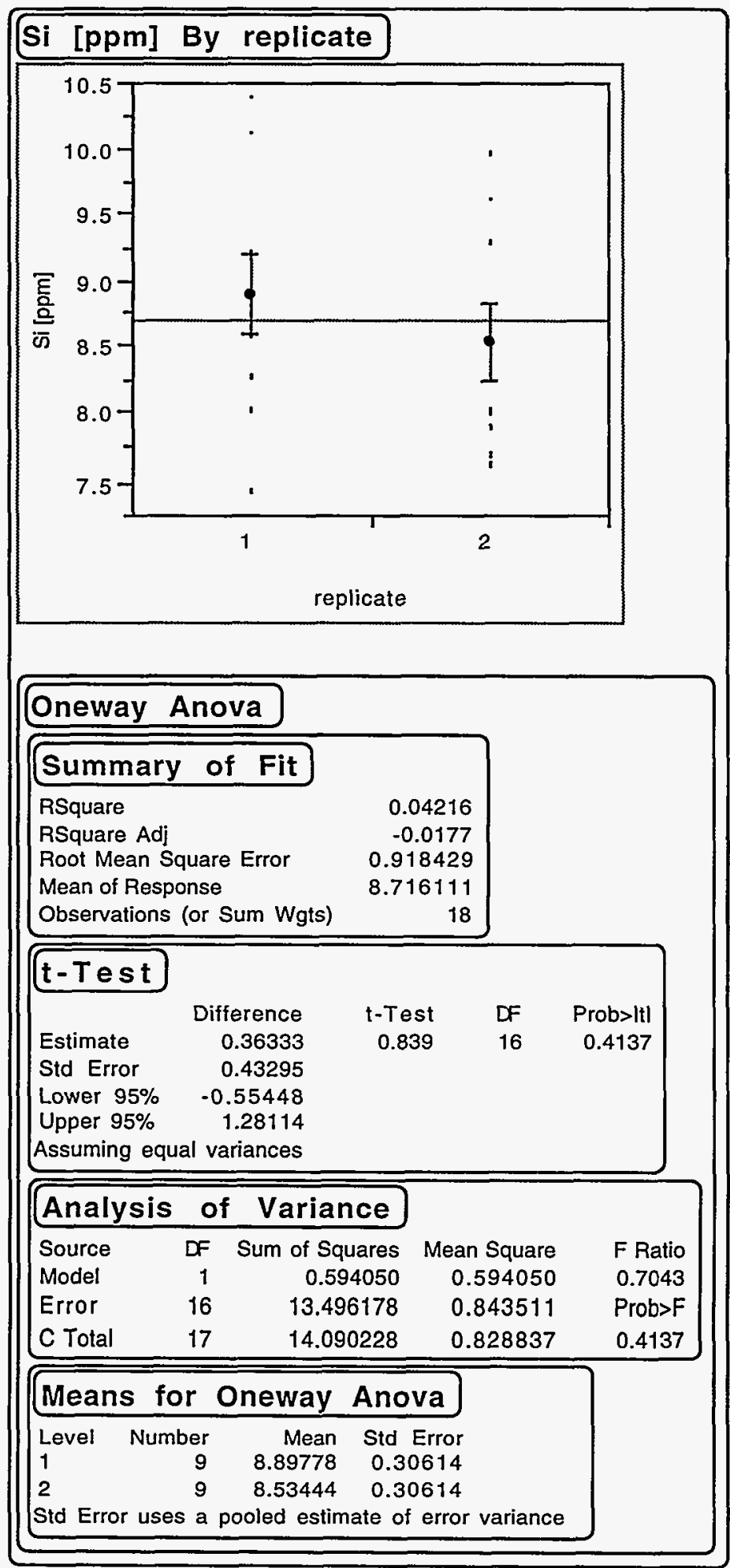


Figure H-4. One-Way ANOVA for Na Concentration in Leachates from 7-day, 70 ${ }^{\circ} \mathrm{C}, 1: 10$ Tests by Replicate.

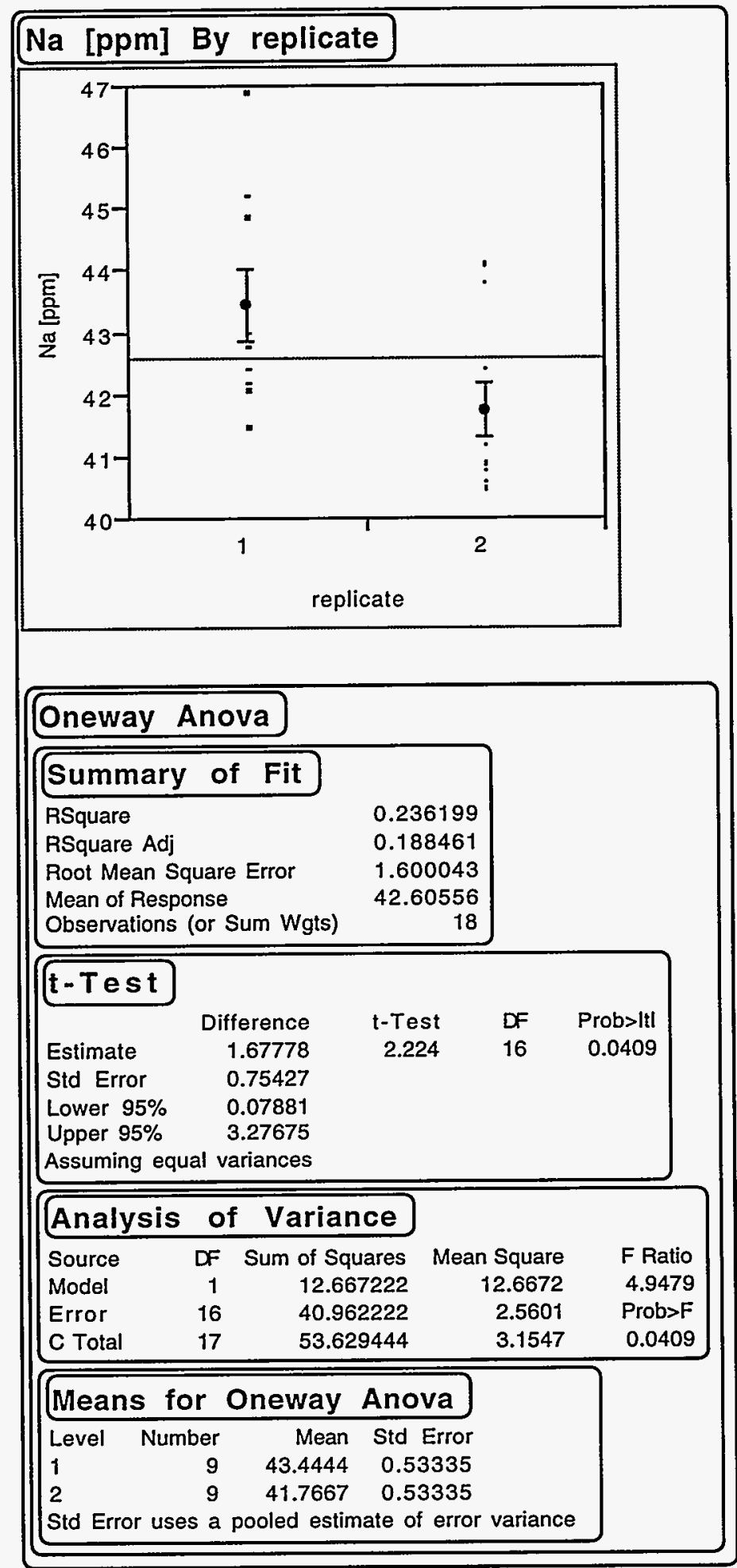


Figure $\mathrm{H}-4$, contd. One-Way ANOVA for Si Concentration in Leachates from 7-day, $70^{\circ} \mathrm{C}, 1: 10$ Tests by Replicate.

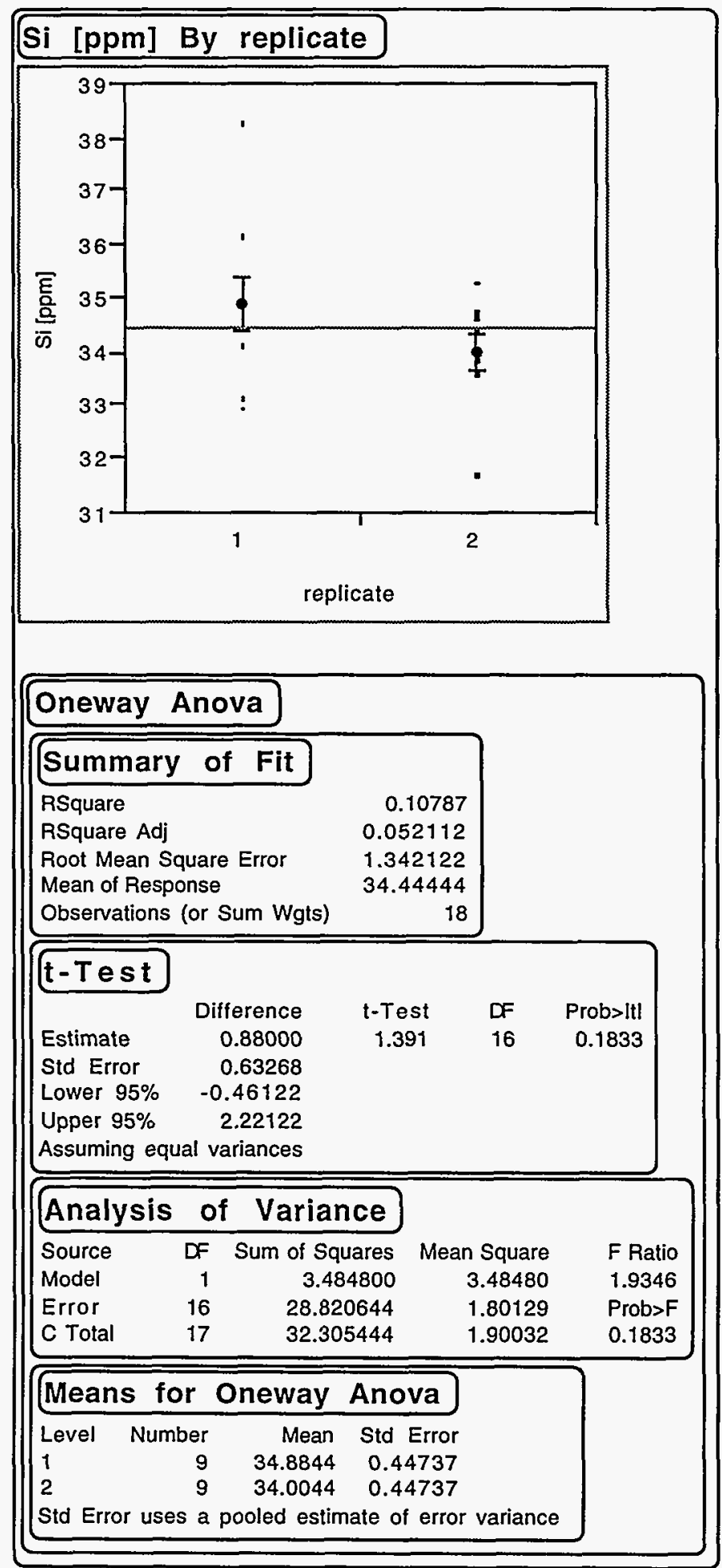


APPENDIX I. ANALYSIS OF VARIANCE OF NORMALIZED ELEMENTAL CONCENTRATIONS BY GLASS/WATER MASS RATIO, TEMPERATURE, AND DURATION

Figure I-1. Comparison of the Standard Deviations of Normalized Na Concentrations by Glass/Water Mass Ratio.

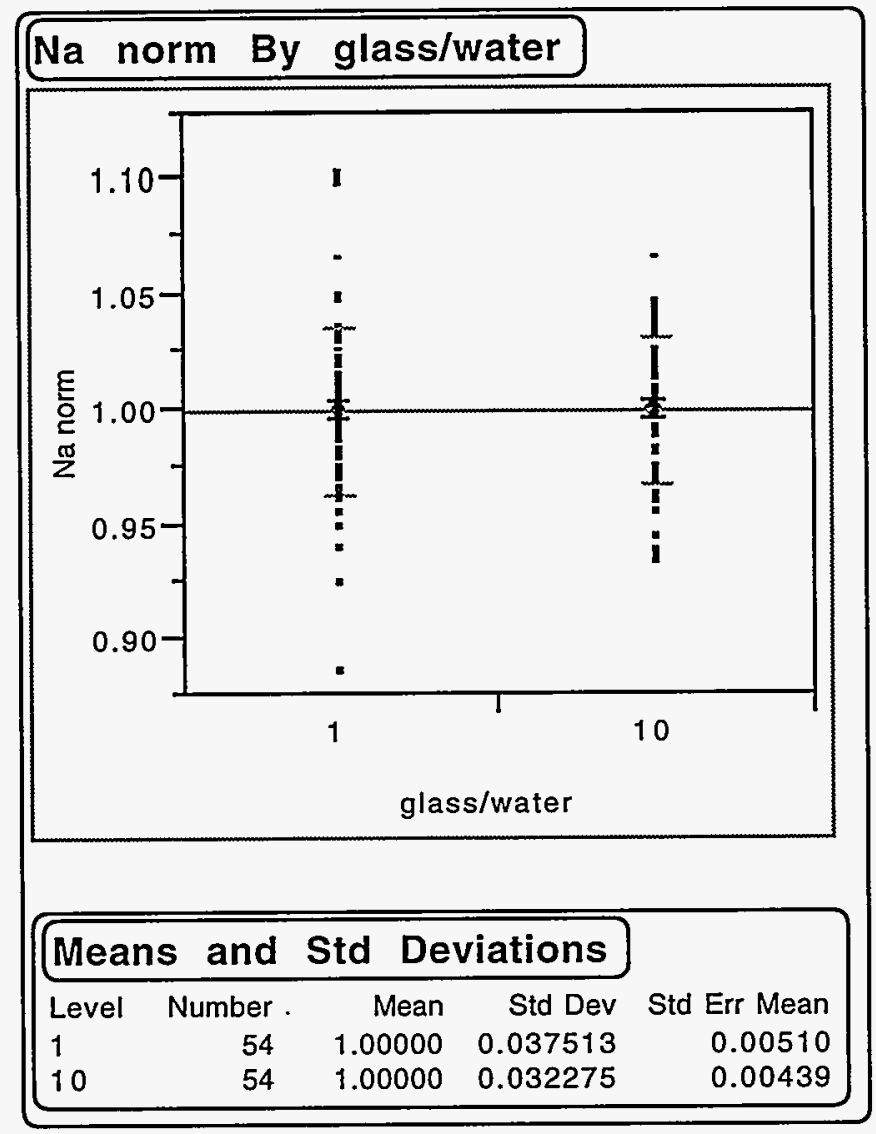


Figure I-1, contd. Comparison of the Standard Deviations of Normalized Si Concentrations by Glass/Water Mass Ratio.

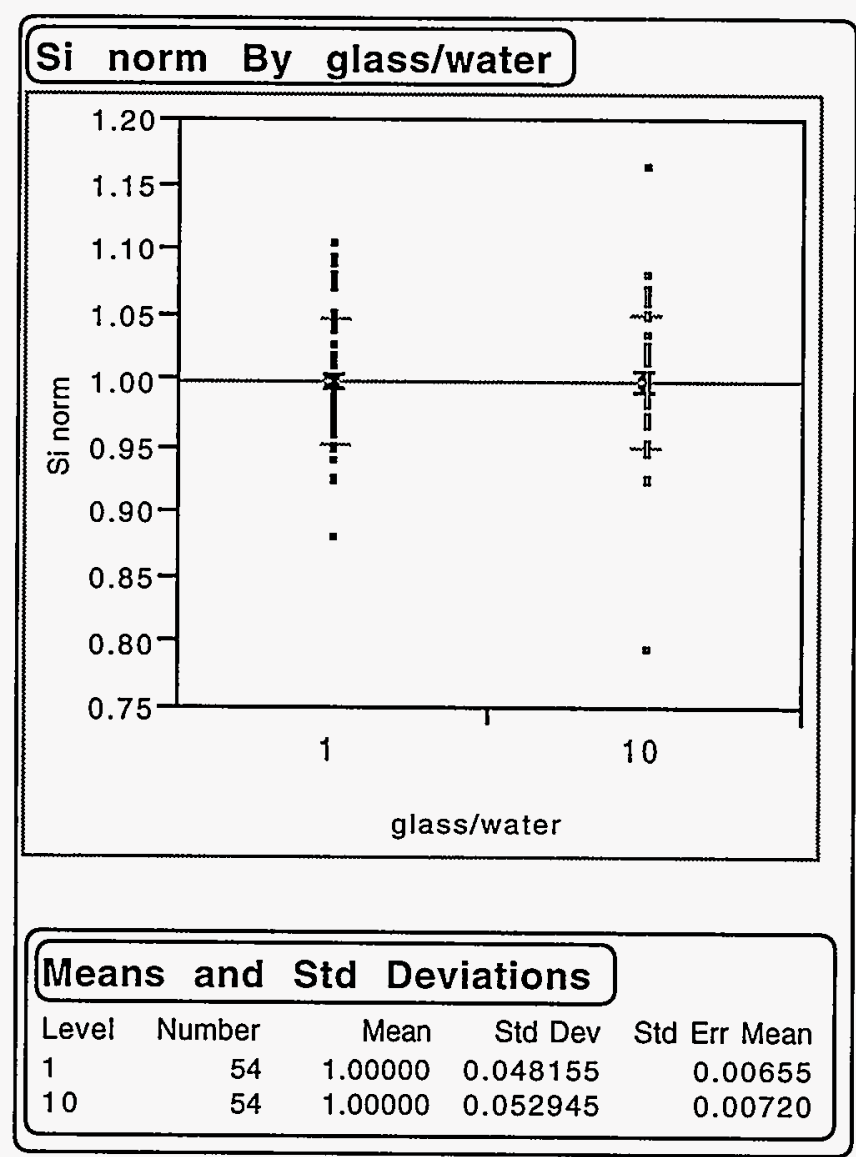


Figure I-1, contd. Comparison of the Standard Deviations of Normalized B Concentrations by Glass/Water Mass Ratio.

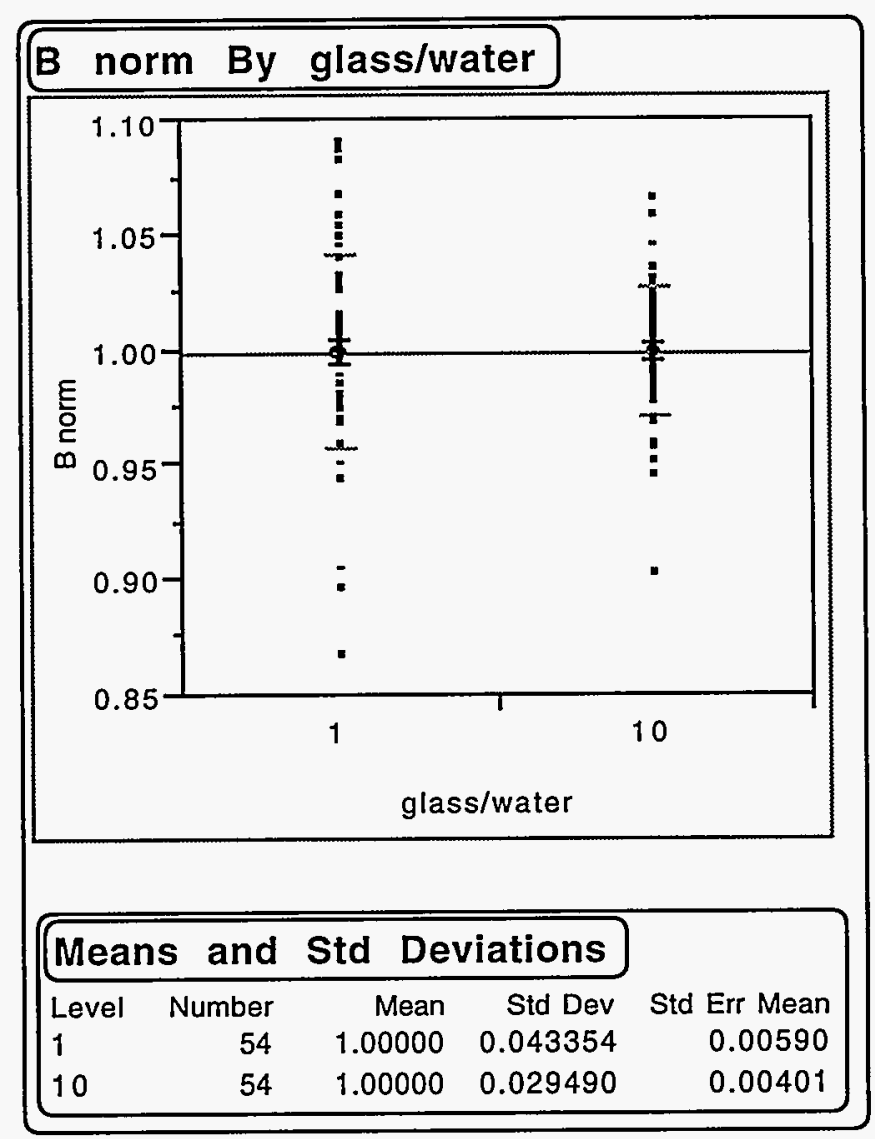


Figure I-2. Comparison of the Standard Deviations of Normalized $\mathrm{Na}$ Concentrations by Temperature.

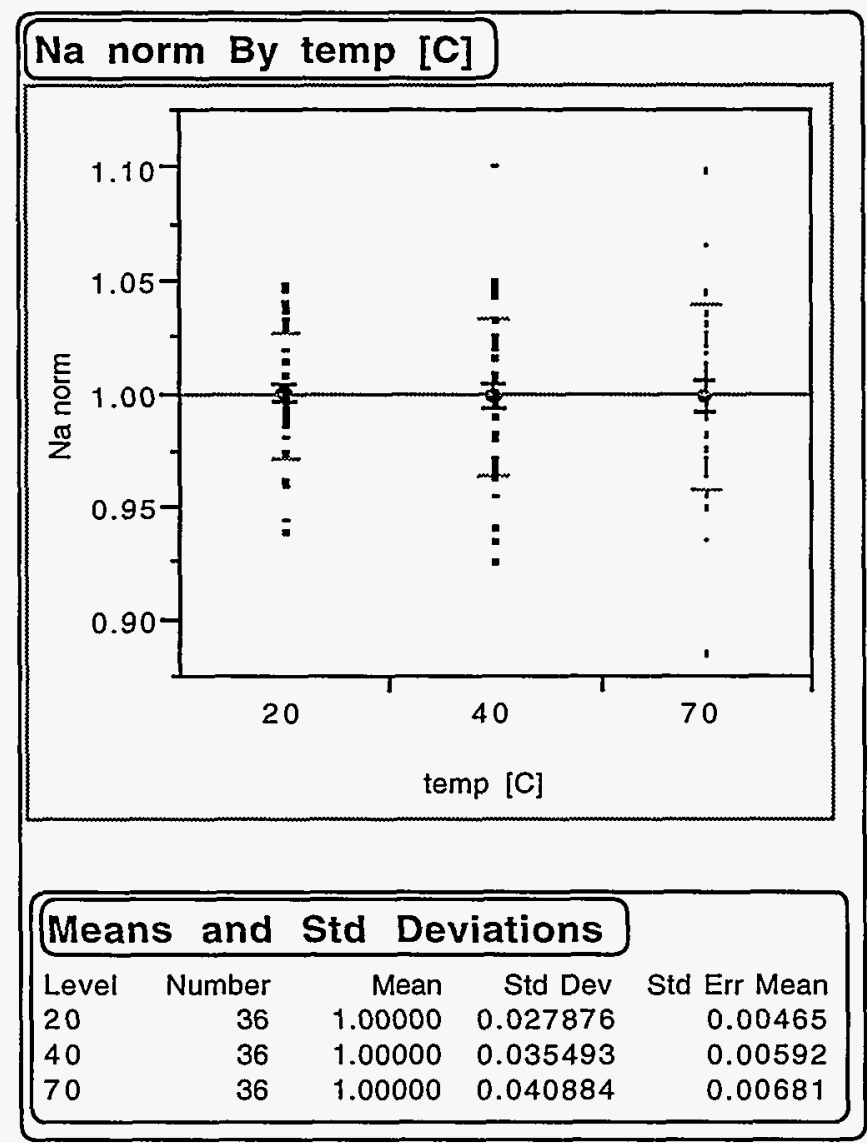


Figure I-2, contd. Comparison of the Standard Deviations of Normalized Si Concentrations by Temperature.

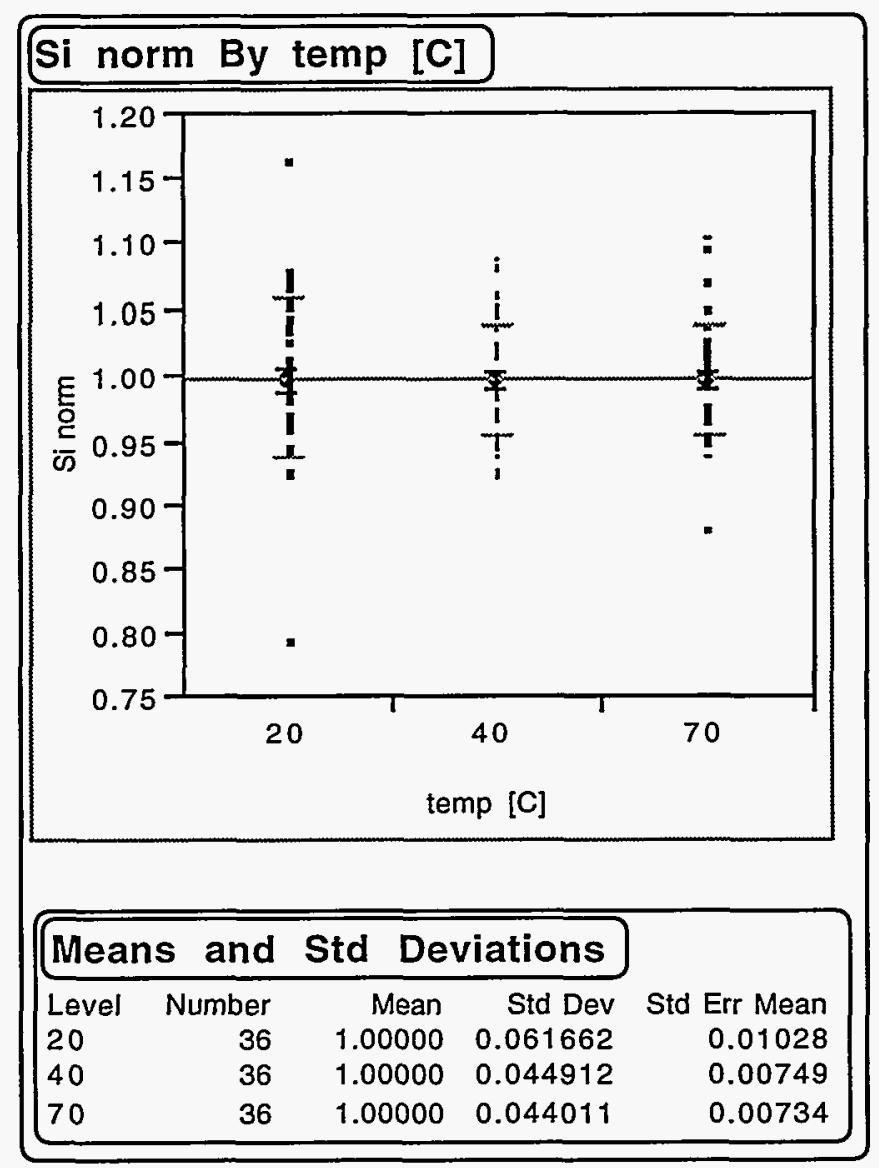


Figure I-2, contd. Comparison of the Standard Deviations of Normalized B Concentrations by Temperature.

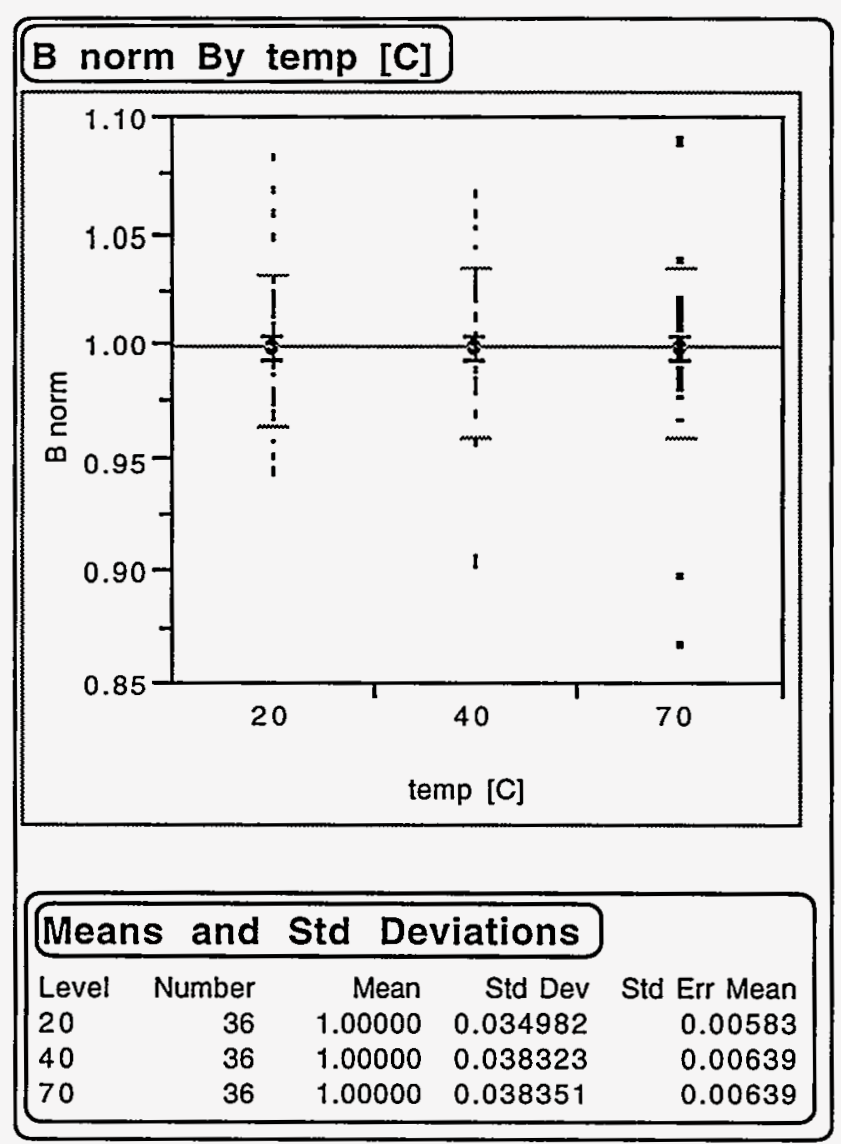


Figure I-3. Comparison of the Standard Deviations of Normalized Na Concentrations by Duration.

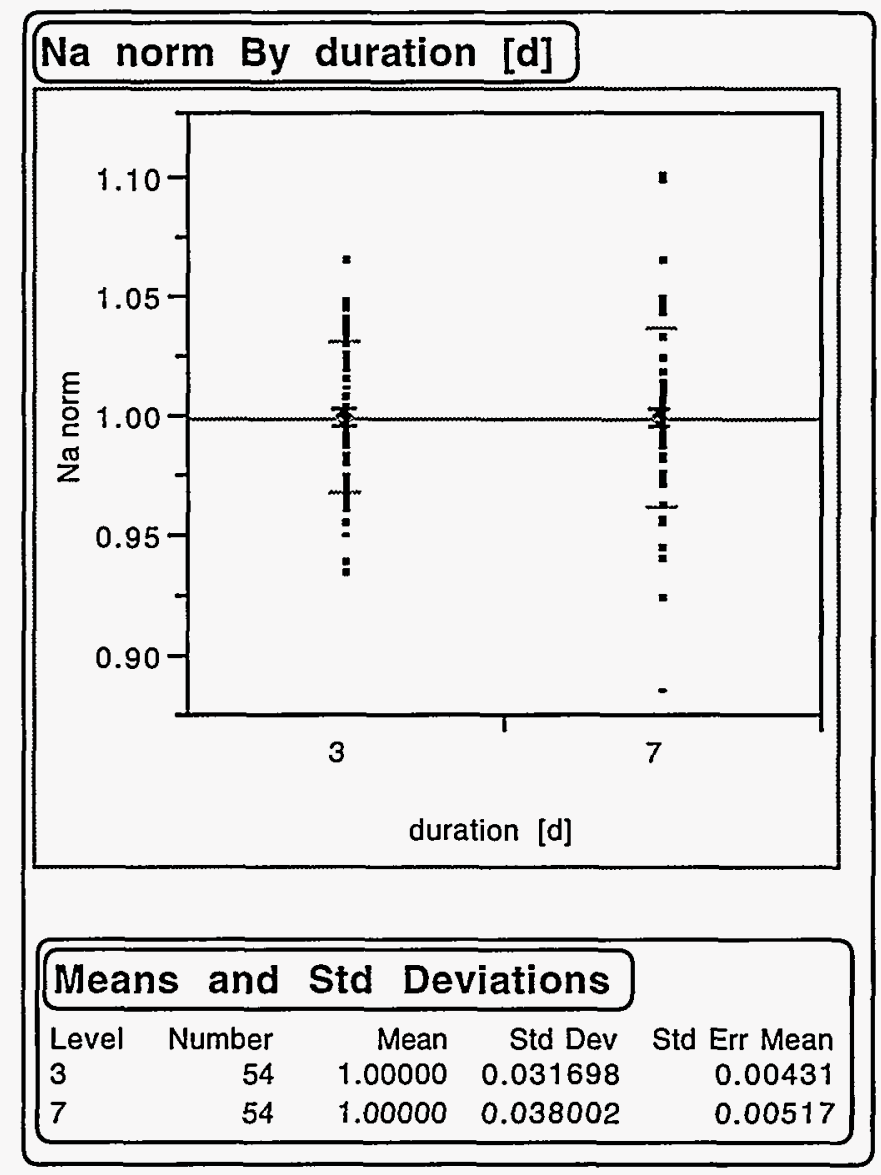


Figure I-3, contd. Comparison of the Standard Deviations of Normalized Si Concentrations by Duration.

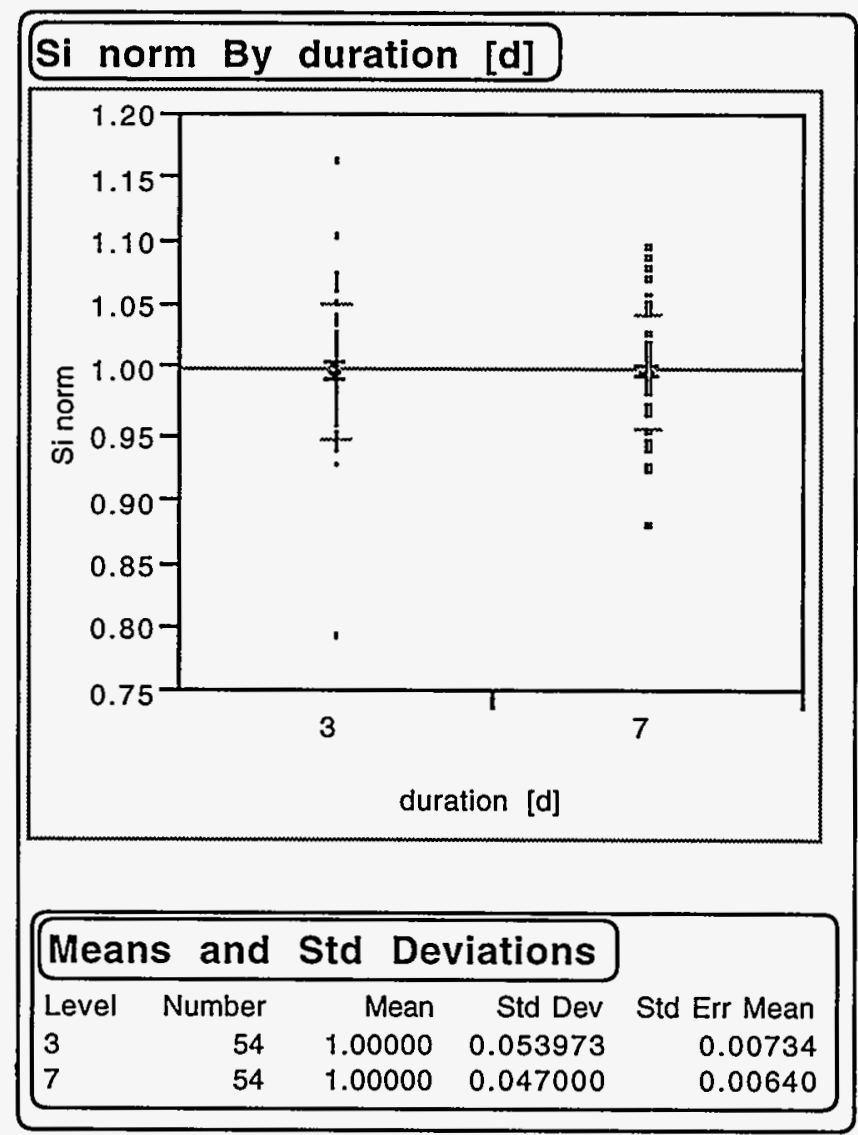


Figure I-3, contd. Comparison of the Standard Deviations of Normalized B Concentrations by Duration.

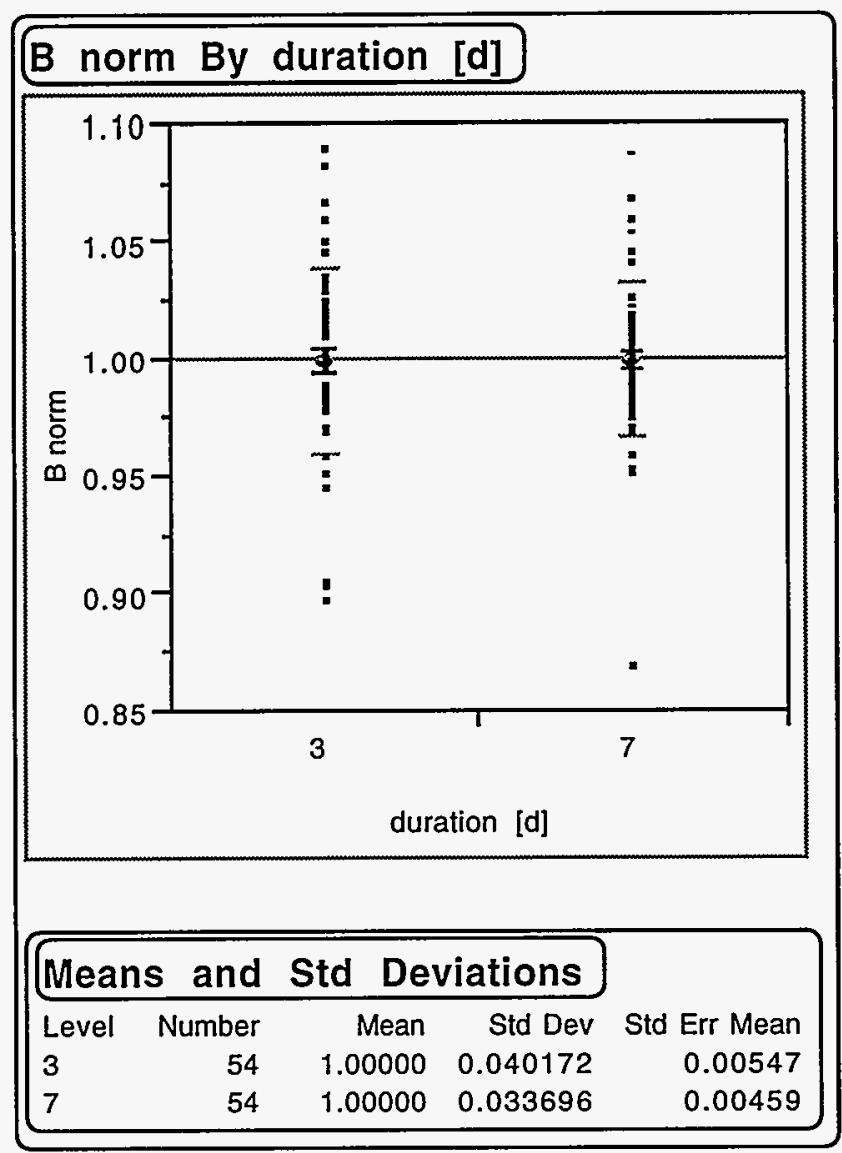


Distribution for ANL-98/9

Internal:
A. J. Bakel
D. W. Green
L. R. Morss
J. K. Bates
J. E. Harmon
L. Nuñez
E. C. Buck
M. C. Hash
D. B. Chamberlain
J. E. Helt
J. C. Cunnane
S. Johnson
W. L. Ebert (25)
J. J. Laidler
R. E. Einziger
M. A. Lewis
T. P. O'Holleran
R. A. Olson
R. T. Riel
L. J. Simpson
W. E. Streets
R. J. Finch
P. C. Lindahl
S. F. Wolf (10)
P. A. Finn
J. S. Luo
J. Fortner
C. J. Mertz
V. N. Zyryanov
TIS Files

M. M. Goldberg

External:

DOE-OSTI (2)

ANL-E Library

ANL-W Library

Manager, Chicago Operations Office, DOE

A. Bindokas, DOE-CH

P. M. Ferrigan, DOE-CH

J. C. Haugen, DOE-CH

Chemical Technology Division Review Committee Members:

H. U. Anderson, University of Missouri-Rolla, Rolla, MO

E. R. Beaver, Monsanto Company, St. Louis, MO

D. L. Douglas, Consultant, Bloomington, $\mathrm{MN}$

R. K. Genung, Oak Ridge National Laboratory, Oak Ridge, TN

J. G. Kay, Drexel University, Philadelphia, PA

R. A. Osteryoung, North Carolina State University, Raleigh, NC

G. R. St. Pierre, The Ohio State University, Columbus, $\mathrm{OH}$

T. Ahn, U.S. Nuclear Regulatory Commission, Washington, DC

M. K. Andrews, Westinghouse Savannah River Company, Aiken, SC

N. E. Bibler, Westinghouse Savannah River Company, Aiken, SC

R. K. Blauvelt, Waste Policy Institute, Dayton, $\mathrm{OH}$

W. L. Bourcier, Lawrence Livermore National Laboratory, Livermore, CA

N. R. Brown, USDOE, Richland Operations Office, Richland, WA

T. B. Calloway, Westinghouse Savannah River Company, Aiken, SC

R. C. Ewing, University of Michigan, Ann Arbor, MI

$X$. Feng, Pacific Northwest National Laboratory, Richland, WA

J. A. Frey, USDOE, Richland Operations Office, Richland, WA (3)

S. S. Fu, Catholic University of America, Vitreous State Laboratory, Washington, DC

S. E. Gomberg, USDOE, Office of Civilian Radioactive Waste Management, Washington, DC

W. Gray, Pacific Northwest National Laboratory, Richland, WA 
T. S. Gutmann, USDOE, Savannah River Operations Office, Aiken, SC

J. H. Holbrook, Pacific Northwest National Laboratory, Richland, WA

E. W. Holtzscheiter, Westinghouse Savannah River Company, Aiken, SC (3)

J. O. Honeymann, Lockheed Martin Hanford Corporation, Richland, WA

P. R. Hrma, Pacific Northwest National Laboratory, Richland, WA

C. G. Interrante, U.S. Nuclear Regulatory Commission, Rockville, MD

A. M. Jensen, Lockheed Martin Idaho Technologies Company, Idaho Falls, ID

D. A. Knecht, Idaho National Engineering and Environmental Laboratory, Idaho Falls, $\mathrm{D}$

B. R. Kowalski, University of Washington, Seattle, WA

D. Kubosumi, Lockheed Martin Idaho Technology Company, Idaho Falls, ID

P. E. LaMont, USDOE, Richland Operations Office, Richland, WA

L. C. Lewis, Lockheed Martin Idaho Technology Company, Idaho Falls, ID

M. E. Lipschutz, Purdue University, West Lafayette, IN

C. S. Louie, USDOE, Richland Operations Office, Richland, WA

F. M. Mann, Lockheed Martin Hanford Company, Richland, WA

B. P. McGrail, Pacific Northwest National Laboratory, Richland, WA

G. B. Mellinger, Pacific Northwest National Laboratory, Richland, WA

J. P. Morin, Westinghouse Savannah River Company, Aiken, SC

J. R. Noble-Dial, USDOE, Oak Ridge Operations Office, Oak Ridge, TN

G. C. Notch, Pacific Northwest National Laboratory, Richland, WA (8)

D. K. Peeler, Westinghouse Savannah River Company, Aiken, SC

I. L. Pegg, Catholic University of America, Vitreous State Laboratory, Washington, DC

G. F. Piepel, Pacific Northwest National Laboratory, Richland, WA

M. J. Plodinec, Mississippi State University, Mississippi State, MS

S. M. Robinson, Oak Ridge National Laboratory, Oak Ridge, TN

A. Sarko, Seiler Pollution Control Systems, Inc., Dublin, OH

G. L. Smith, Pacific Northwest National Laboratory, Richland, WA

D. Stahl, Framatome Cogema Fuels, Las Vegas, NV

B. Staples, Lockheed Martin Idaho Technology Company, Idaho Falls, ID

D. M. Strachan, Pacific Northwest National Laboratory, Richland, WA

T. A. Thornton, Framatome Technologies, Inc., Las Vegas, NV

J. D. Vienna, Pacific Northwest National Laboratory, Richland, WA

E. T. Weber, Kennewick, WA

J. H. Westsik, Pacific Northwest National Laboratory, Richland, WA

G. G. Wicks, Westinghouse Savannah River Company, Aiken, SC

C. N. Wilson, Lockheed Martin Hanford Company, Richland, WA

P. E. Woodall, USDOE, Idaho Operations Office, Idaho Falls, DD

M. Aertsens, Centre d'Etude de L'Energie Nucleaire, Boeretang, BELGIUM

R. Baschwitz, Cogema, Velizy Cedex, FRANCE

E. Curti, Paul Scherrer Institute, Villigen, SWITZERLAND

B. Grambow, Kernforschungszentrum Karlsruhe Institut, Karlsruhe, GERMANY

W. Hecke, Seiler Nuclear Control, Inc., Vienna, AUSTRIA

L. Johnson, Atomic Energy of Canada, Ltd., Pinawa, Manitoba, CANADA

S. Luo, China Institute of Atomic Energy, Beijing, CHINA

P. Van Iseghem, Centre d'Etude de L'Energie Nucleaire, Boeretang, BELGIUM

E. R. Vance, Australian Nuclear Science \& Technology, Lucas Heights, AUSTRALIA

E. Vernaz, Centre d'Etudes Nucleares de la Valle du Rhone, Marcoule, FRANCE

C. M. Veyer, Commissariat a L'Energie Atomique - SCD, Saint Waast La Vallee, FRANCE 